\title{
Interior Design of Care Homes for People with Alzheimer's Disease: A Comparative Study
}

Tina Krliu

School of Architecture and Design at the University American College Skopje, Skopje, Republic of Macedonia

Citation: Krliu T. [Interior Design of Care Homes for People with Alzheimer's Disease: A Comparative Study]. SEE J Arch Des. 2016 Nov 09; 10024. [MSc] [Macedonian] http://dx.doi.org/10.3889/seejad.2016.10024

Key words: Alzheimer's disease; Macedonian long-term care; Canadian long-term care; interior design; comparative case study; design modifications; evaluation too

Correspondence: Tina Krliu. School of Architecture and Design at the University American College Skopje, Skopje, Republic of Macedonia. E-mail: tinakrliu@gmail.com

Received: 01-Jul-2016; Revised: 20-Jul-2016; Accepted: 30Oct-2016; Published: 09-Nov-2016

Copyright: $\odot 2016$ Tina Krliu. This is an open-access article distributed under the terms of the Creative Commons distribution, and reproduction in any medium, provided the original author and source are credited.

Competing Interests: The author have declared that no competing inter

\section{Abstract}

BACKGROUND: The population of people with Alzheimer's disease (AD) is rapidly increasing worldwide. While in Republic of Macedonia there is no formal special care for people with AD, developed countries are expanding on both the typology of their care homes and services they offer for people with AD. The Macedonian aging population is in need of long-term care (LTC) options tailored to meet the special needs of people with $A D$.

AIM: The aims of this study are (i) to explore the Macedonian approach to the problem of creating LTC environments for people with $A D$, as compared to the approach of a developed country through the example of Canada, and (ii) to identify successful interior design characteristics that would meet the special needs of people with $A D$.

METHODS: The study begins by reviewing existing literature with the purpose of obtaining knowledge about the common clinical symptoms of $A D$ (i.e. memory problems and behavior) and how these changes have an impact on the interaction between $A D$ individuals and the physical environment they live in. For the purposes of the study, a fieldtrip was conducted in two LTC homes in Toronto (Canada) offering special 24 hour care for people with AD, and one LTC home in Skopje (Macedonia) that includes people with AD in their care program. The interior design of LTC homes was described through photographs, plans, observations and a description of the spaces used by people with AD. For a controlled analysis of the recorded environments, the 'Evaluation of Older People's Living Environments (EVOLVE)' questionnaire was used.

RESULTS: The identified qualities from the case studies, and the lessons learned throughout the analysis of the key design elements, were used towards developing a list of suggestions for modifying the interior of the Macedonian LTC home. The developed suggestions were classified into two groups: (1) proposals for minimal constructional modifications of the interior environment, and (2) proposals for major constructional modifications of the interior environment.

CONCLUSION: While the suggested modifications are not final changes of the LTC environment, they are an important step towards developing a design strategy for providing 24 hour care for people with $A D$ in Macedonia. 


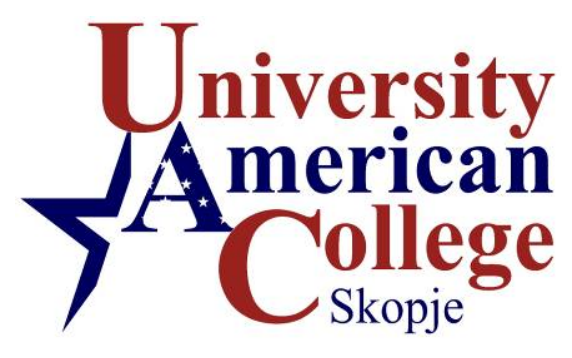

\title{
УНИВЕРЗИТЕТ АМЕРИКАН КОЛЕЏ - СКОПЈЕ
}

ФАКУЛТЕТ ЗА АРХИТЕКТУРА И ДИЗАЈН

\author{
Магистерски труд
}

Внатрешно уредување на домови за нега на лица со Алцхајмерова болест: Компаративна студија

Кандидат:

Тина Крлиу
Ментор:

Д-р Владимир Ладински

\section{Скопје}

Maj, 2013 



\begin{abstract}
АПСТРАКТ
Предмет на оваа студија е внатрешното уредување на домовите за згрижување на лицата во првиот и вториот стадиум на АБ. Целта на студијата е споредбено да се разгледа пристапот кон овој аспект во Република Македонија и во поразвиените средини во светот преку примерот на Канада; да се разбере интеракцијата помеѓу внатрешното уредување на просторот и лицата со АБ и заклучно на сето тоа, да се извлечат поуки за тоа која е најдобрата пракса во внатрешното уредување на домовите за згрижување на лицата со АБ, а преку кои се поддржува и промовира нивната самостојност.
\end{abstract}

За остварување на целите на истражувањето беа снимени три домови со долготрајна нега на стари лица кои згрижуваат лица со АБ во првиот и вториот стадиум на болеста. Едниот од домовите се наоѓа во Скопје, Република Македонија, а другите два во Торонто, Канада. Снимањето на домовите се состоеше од: фотографско снимање на просторот, изработка на скици од станбените единици; спроведен разговор со лице во улога на водич за време на посетата и визуелна опсервација на просторот и генералното однесување на станарите низ него. По снимањето на домовите следеше процесот на изработка на студијата за којшто беа одговорени прашања од евалуацискиот прашалник EVOLVE. Резултатите генерирани од прашалникот беа анализирани паралелно со преглед на литература за темата, при што се извлекоа поуки во вид на препораки, врз основа на кои на крајот се изработија сугестии за можни интервенции за приспособување на просторот за употреба од лицата со АБ во домот Мери Терзиева.

Додека наведените модификации не се конечни модификации кои засекогаш ќе ги променат условите за лице со АБ во средина наменета за стари лица без АБ, тие можат да претставуваат прв чекор кон подобрување на условите во средина која треба постојано да се надополнува во зависност од можноста на домот и врз основа на новите откритија од истражувањата.

Клучни зборови: Алцхајмерова болест, Македонски домови за долготрајна нега на стари лица, Канадски домови за долготрајна нега на стари лица, компаративна студија, внатрешно уредување, модификации, евалуациски прашалник 

До:

Факултетот за архитектура и дизајн

при Универзитетот Американ Колеџ - Скопје

\section{ИЗЈАВА ЗА АВТЕНТИЧНОСТ НА МАГИСТЕРСКИОТ ТРУД}

Jac, Тина Крлиу студент на втор циклус на студии на Факултетот за архитектура и дизајн при Универзитетот Американ Колеџ Скопје, насока Внатрешна архитектура, изјавувам дека при изработка на магистерскиот труд со наслов: ги почитував законските прописи од областа на заштита на интелектуалната сопственост и авторските права и не користев речници или делови од други автори без да ги почитувам методолошките стандарди. Изјавата ја давам под материјална и кривична одговорност.

Подносител:

Потпис:

Тина Крлиу

Втор циклус студии насока Внатрешна архитектура

ID 9017

Скопје, 2013 година 



\section{БЛАГОДАРНОСТ}

Би сакала да ја искажам својата благодарност до проф. д-р Владимир Ладински, за неговото залагање, пренесеното знаење и искуство, како и неговата несебична поддршка за време на изработката на трудот. Особена благодарност до домовите Мери Терзиева во Скопје, Humber Heights и Villa Colombo во Торонто кои овозможија пристап и фотографско снимање на ентериерот наменет за употреба од станарите во домот. Благодарност и до архитектот Robert Anderson (architect, Carson Woods Architects Limited) за основата на катот за потпомогнато домување во Humber Heights, како и до Carmen V. DiMauro (chief executive officer, Villa Colmbo) за основата на катот за долготрајно домување на лица со Алцхајмерова болест и други видови на деменција во домот Villa Colombo. И најпосле, би сакала да изразам голема благодарност до моите родители и сопругот за помошта, разбирањето и истрајноста во поддршката. 


\section{СОДРЖИНА}

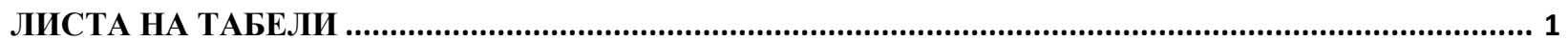

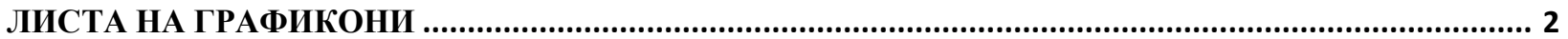

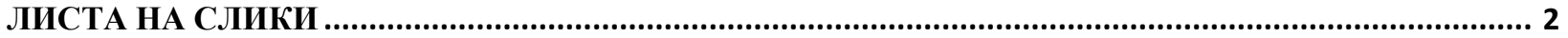

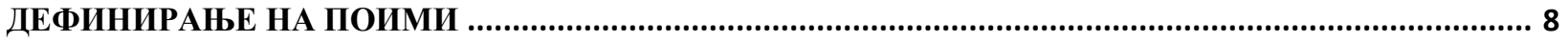

КРАТЕНКИ КОРИСТЕНИ ВО ТРУ ДОТ .........................................................................................10

1. ВОВЕД

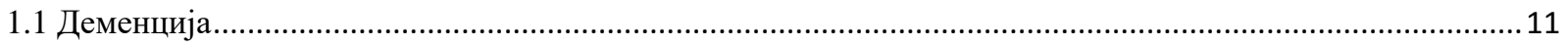

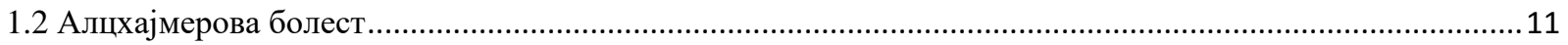

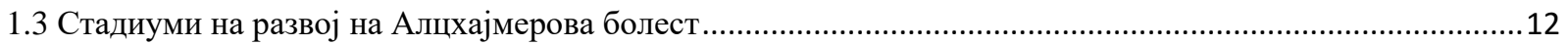

1.4 Нарушувања предизвикани од АБ кои влијаат врз односот со опкружувањето ……………………….....13

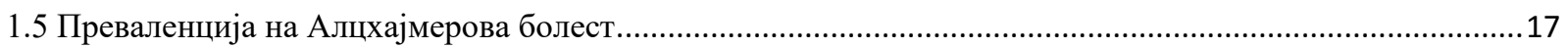

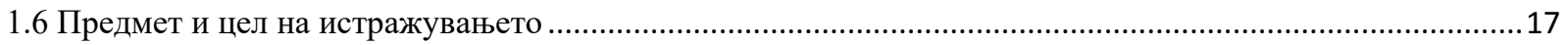

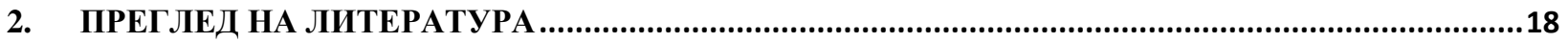

2.1 Типологија на домови со нега за лица со Алцхајмерова болест ……....................................................18

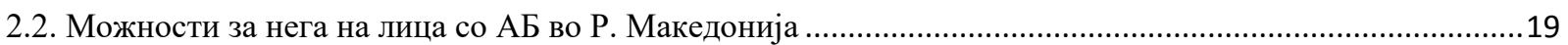

2.3. Предност на живеење во дом за нега на лица со пречки во помнењето...................................................21

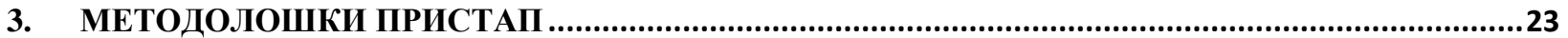

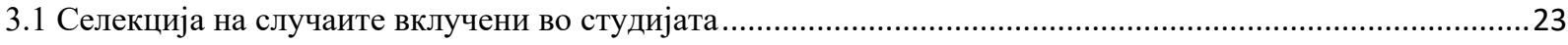

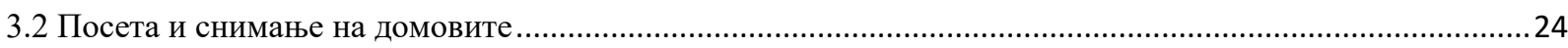

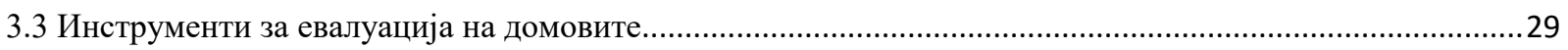

3.4 Рамки на истражувањето ……………..............................................................................................

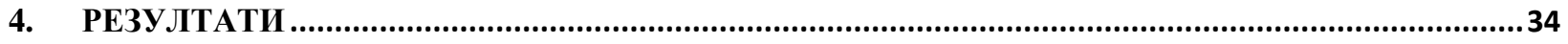

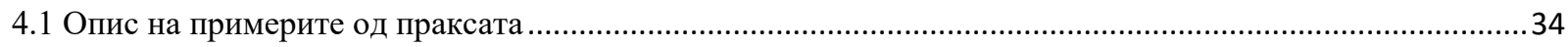

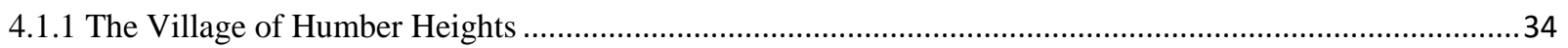

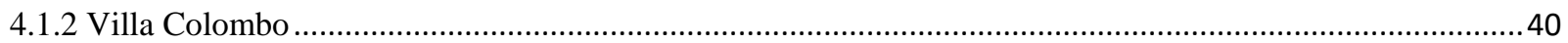

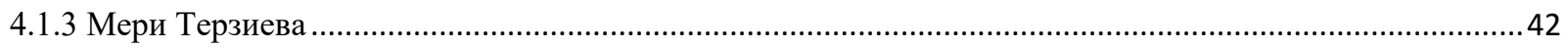

4.2 Споредба на резултатите од одговорените прашања од евалуацискиот прашалник EVOLVE.................45

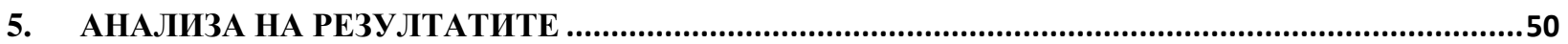

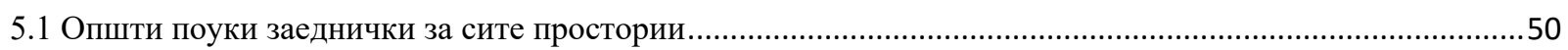

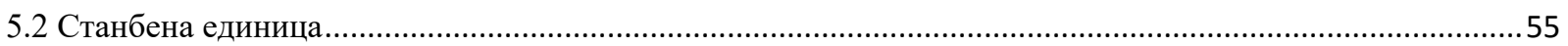

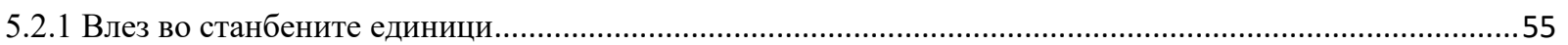

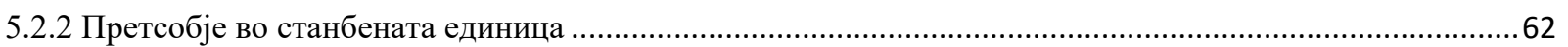

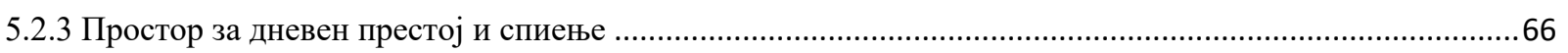

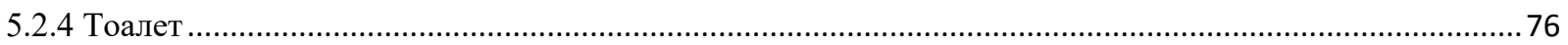

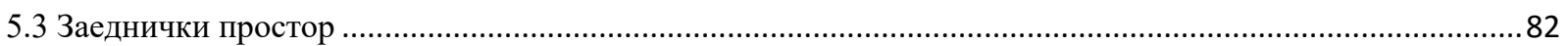

5.3.1 Комуникациски врски помеѓу станбените единици и заедничкиот простор .........................................83 
6. СУГЕСТИИ ЗА МОЖНИ МОДИФИКАЦИИ НА ПРОСТОРИ ВО ДОМОТ МЕРИ ТЕРЗИЕВА ЗА ПОТРЕБИТЕ НА ЛИЦА СО АЛЦХАЈМЕРОВА БОЛЕСТ ............................................................................100

6.1 Сугестии за можна модификација на простори во домот Мери Терзиева за потребите на лицата со

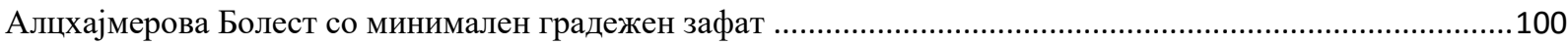

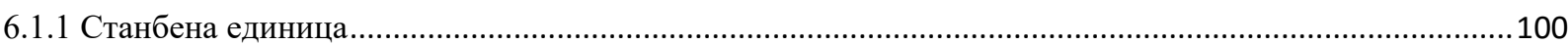

6.2 Сугестии за можна модификација на простори во домот Мери Терзиева за потребите на лицата со

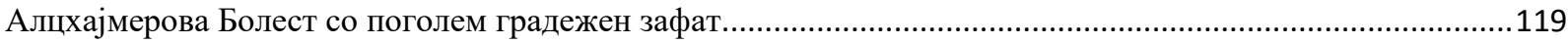

6.2.1 Станбена единица........................................................................................................................119

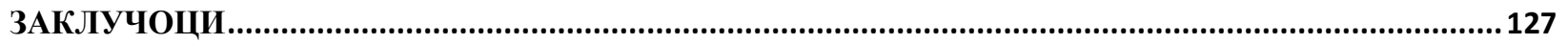

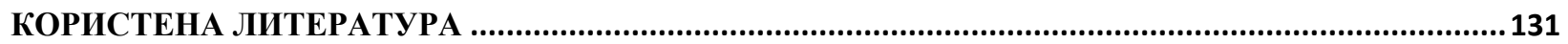

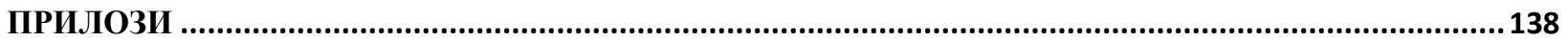

П.1 Одговорен евалуациски прашалник за домот Humber Heights ...........................................................138 


\section{ЛИСТА НА ТАБЕЛИ}

Табела 1 - Талеска (2012). Капацитет на приватни лиценцирани установи за стари лица. Нова Македонија, 22485 - 1 јануари 2012. Достапно на:

http://www.novamakedonija.com.mk/NewsDetal.asp?vest=12112935164\&id=9\&prilog=0\&setlzdanie=2

2485. Пристапено на: 21.06.2012.

Табела 2 - Општи податоци за снимените домови за нега на лица со АБ. Извор: авторот. .24

Табела 3 - Споредба на резултатите за станбените единици генерирани од EVOLVE. Извор: авторот.

Табела 4 - Споредба на резултатите за заедничките простори генерирани од EVOLVE. Извор:

авторот.

Табела 5 - Споредба на резултатите за циркулацијата низ просторот генерирани од EVOLVE.

Извор: авторот.

Табела 6 - Општи препораки заеднички за сите простори. Извор: авторот.

Табела 7 - Предлози за тоалетот извлечени од прегледаната литература. Извор: авторот 54

Табела 8 - Препораки за влезот во станбената единица. Извор: авторот. .55

Табела 9 - Предлози за влезот во станбените единици извлечени од прегледаната литература.

Извор: авторот 62

Табела 10 - Препораки за претсобјето во станбената единица. Извор: авторот.

Табела 11 - Препораки за просторот за дневен престој и спиење во станбена единица. Извор: авторот.

Табела 12 - Предлози за просторот за дневен престој и спиење извлечени од прегледаната литература. Извор: авторот.

Табела 13 - Препораки за тоалетот во станбена единица. Извор: авторот.

Табела 14 - Предлози за тоалетот извлечени од прегледаната литература. Извор: авторот. .82

Табела 15 - Препораки за ходниците во домот МТ. Извор: авторот. .83

Табела 16 - Предлози за ходниците извлечени од прегледаната литература. Извор: авторот. .......92

Табела 17 - Препораки за заедничкиот дневен простор. Извор: авторот. .92

Табела 18 - Предлози за заедничката дневна соба извлечени од прегледаната литература. Извор: авторот. 


\section{ЛИСТА НА ГРАФИКОНИ}

Графикон 1 - Потврден и негативен одговор на прашањата од евалуацијата за станбените единици, изразени во проценти (\%). Извор: авторот. 46

Графикон 2 - Потврден и негативен одговор на прашањата од евалуацијата за заедничките простории, изразени во проценти (\%). Извор: авторот.

Графикон 3 - Потврден и негативен одговор на прашањата од евалуацијата за циркулација низ просторот, изразени во проценти (\%).Извор: авторот...... 48

\section{ЛИСТА НА СЛИКИ}

Слика 1 - Дијаграм за процес на изработка на студијата на случај. Извор: авторот. 28

Слика 2 - Ситуација на домот НН. Извор: Google Maps (2013). Humber Heights Village Of, Etobicoke,

Toronto. Available at: http://goo.gl/maps/gT80d [Accessed 12 May 2013]...... 35

Слика 3 - Атриумот на приземјето во домот НН Извор: Concrete Floor Tek, (2013), The main lobby [ONLINE]. Available at: http://www.concretefloortek.com/photos/humber/vandel1.jpg [Accessed 20

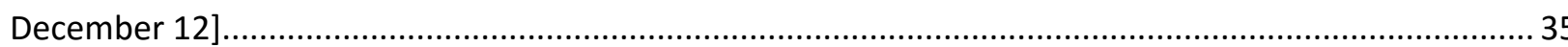

Слика 4 - Содржини во одделот за лица со пречки во помнењето во домот НН. Извор: авторот. .. 36

Слика 5 - Линија на движење на станарот низ содржините на домот НН. Извор: авторот.

Слика 6 - Основа на студиото со кревет поставен до прозор. Извор: Schlegel Villages, (2012), Memory care [ONLINE]. Available at:

http://schlegelvillages.com/sites/default/files/Etobicoke/Living_Choices_floor_plans/Floor\%20plans325\%20sq\%20ft.jpg [Accessed 20 Dec 2012]

Слика 7- Основа на студиото со кревет поставен поблизу до тоалетот. Извор: Schlegel Villages, (2012), Memory care [ONLINE]. Available at: http://schlegelvillages.com/sites/default/files/Etobicoke/Living_Choices_floor_plans/Floor\%20plans325\%20sq\%20ft.jpg [Accessed 20 December 12].

Слика 8- Ситуација на домот VT. Извор: Google Maps (2013). Villa Colombo Homes for the Aged Inc, Toronto. Available at: http://goo.gl/maps/c7M6B [Accessed 12 May 2013]. 40

Слика 9 - Ситуација на домот МТ. Извор: Google Maps (2013). Geriathry "Meri Terzieva", Skopje. Available at: http://goo.gl/maps/Fvrll [Accessed 12 May 2013]. 
Слика 10- Главниот влез во домот МТ. Извор: Домот Мери Терзиева, (2009), Главниот влез во домот Мери Терзиева [ONLINE]. Available at: http://dom-terzieva.mk/images/kapacitet/04.jpg [Accessed 10 October 12].

Слика 11- Скалишниот простор во МТ. Извор: Домот Мери Терзиева, (2009), Влезниот хол во домот Мери Терзиева [ONLINE]. Available at: http://dom-terzieva.mk/images/kapacitet/05.jpg [Accessed 10 October 12].

Слика 12- Дворот во МТ. Извор: Домот Мери Терзиева, (2009), Дворот на домот Мери Терзиева [ONLINE]. Available at: http://dom-terzieva.mk/images/kapacitet/03.jpg [Accessed 10 October 12] .....44

Слика 13 - Ознаки со бројот на станбената единица и името на станарот којшто е сместен во единицата. Извор: авторот.

Слика 14 - Лични предмети на станарот закачени на влезната врата од станбената единица. Извор: авторот.

Слика 15 - Рамномерно распределено осветлување во ходникот на домот НН и начин на осветлување на влезовите во станбените единици. Извор: авторот.

Слика 16 - Осветлувањето во ходникот и до влезовите на станбените единици во домот VC. Извор: авторот.

Слика 17 - Осветлувањето во ходникот во домот МТ. Извор: авторот 61

Слика 18 - Претсобјето во домот МТ. Извор: авторот.

Слика 19 - Гардероберот во домот VC кој што се наоѓa во спалниот простор. Извор: авторот. 64

Слика 20 - Гардероберот во претсобјето на станбените единици во НН. Извор: авторот. 65

Слика 21 - Место за ТВ уред во станбената единица на домот МТ. Извор: авторот. 68

Слика 22 - Место за ТВ уред во станбената единица на домот НН. Извор: авторот 68

Слика 23 - Алармен уред за повик на помош во станбената единица во домот НН. Извор: авторот.

Слика 24 - Алармен уред за повик на помош во станбената единица во домот МТ Извор: авторот.

Слика 25 - Дијаметар од 1500мм за завртување на инвалидска количка во станбената единица на МТ. Извор: авторот.

Слика 26 - Креветот и катчето за дневен престој во станбената единица на домот НН. Извор: авторот 
Слика 27 - Дијаграми со линии на движење на станарите од креветот до тоалетот во станбените единици. Извор: авторот.

Слика 28 - Дијаграми со модификации на линиите на движење на станарите од креветот до тоалетот во станбените единици на МТ. Извор: авторот. 75

Слика 29 - Појава на праг на влезот од тоалетот во станбената единица во домот МТ. Извор: авторот. 78

Слика 30 - Тоалетот во станбената единица во домот НН. Извор: авторот. .78

Слика 31 - Тоалетот во станбената единица во домот VC. Извор: авторот. .79

Слика 32 - Дијаграм којшто го прикажува препорачаниот дијаметар на слободен простор од 1500мм нанесен врз површината на тоалетот во МТ. Извор: авторот. .80

Слика 33 - Дијаграми на формите на ходниците во снимените домови. Извор: авторот. .85

Слика 34 - Скалите во ходникот на домот Мери Терзиева. Извор: од авторот. .87

Слика 35 - Ракофати во ходникот на домот НН. Извор: авторот .88

Слика 36 - Ракофати во ходникот на домот VC. Извор: авторот .89

Слика 37 - Присуство на одблесок и темни предели во ходникот на домот МТ. Извор: авторот. ...99

Слика 38 - Тркало на боја. Извор: Lighthouse International, (2005), Color wheel [ONLINE]. Available at: http://www.lighthouse.org/images/content/accessibility/color_wheel.gif [Accessed 08 January 13]..... 91

Слика 39 - Шематски приказ на содржините во просторот за дневен престој во домот НН. Извор: авторот.

Слика 40 - „Станица за животни вештини“ за дотерување во дневниот простор на домот НН. Извор: авторот. .94

Слика 41 - Поглед кон местото за седење покрај ТВ уредот во просторот за дневен престој во НН. Извор: авторот.

Слика 42 - „Станица за животни вештини“ за нега на бебе во дневната соба на домот НН. Извор: авторот. 96

Слика 43 - Поглед кон каминот во дневниот простор на домот НН и местото за седење до каминот. Извор: авторот.

Слика 44 - Поглед кон пијаното поставено помеѓу дневниот простор и семејната кујна во домот НН. Извор: авторот. 97

Слика 45 - Дневната соба во домот VC. Извор: авторот. 98 
Слика 46 - Сугестии за можна модификација на простори во домот МТ со минимален градежен зафат изразени преку три варијанти. Извор: авторот.

Слика 47 - Фотографија и скица на постојна состојба на плакарот во претсобјето и сугестија за нов плакар. Извор: авторот.

Слика 48 - Предлог за изгледот на внатрешноста на плакар со помали димензии изработен по мерка. Извор: IKEA, (2013), PAX Wardrobe with interior organizers [ONLINE]. Available at: http://www.ikea.com/us/en/catalog/products/S59932735/ [Accessed 17 May 13].

Слика 49 - Пример за закачалка/полица која би можела да се постави зад вратата во Варијанта 1 и 2. Извор: IKEA, (2013), STÄLL Hat rack, birch, stainless steel [ONLINE]. Available at: http://www.ikea.com/us/en/catalog/produhttp://www.harvardgenerator.com/references/onlineimagects/S59932735/ [Accessed 17 May 13]. 105

Слика 50 - Пример за клупа за чевли која би можела да се постави зад вратата во Варијанта 1 и 2. Извор: IKEA, (2013), STÄLL Shoe rack [ONLINE]. Available at: http://www.ikea.com/us/en/catalog/products/20152667/ [Accessed 17 May 13] 106

Слика 51 - LED ленти поставени околу рамка на врата. Извор: Lighting Research Center, (2005), Around the bathroom door frame [ONLINE]. Available at: http://www.Itlmagazine.com/article/hottechnologies-advanced-lighting-technologies-enhance-resident-care [Accessed 29 April 13]. 107

Слика 52 - LED ленти поставени над мијалникот. Lighting Research Center, (2005), Under the mirror and handrail in the bathroom [ONLINE]. Available at: http://www.It/magazine.com/article/hottechnologies-advanced-lighting-technologies-enhance-resident-care [Accessed 29 April 13]. 108

Слика 53 - Декоративна маска за покривање на радијаторот. Извор за маската: Westchester Woodcrafters, (2013), Shaker [ONLINE]. Available at: http://www.westchesterwoodcrafters.com/radiator\%20covers.html [Accessed 17 May 13] 109

Слика 54 - Предлог за фотелја која ги задоволува условите за употреба од стари лица. Извор: IKEA, (2013), STRANDMON Wing chair, Svanby gray [ONLINE]. Available at:

http://www.ikea.com/ca/en/catalog/products/90251659/ [Accessed 30 March 13]. 111

Слика 55 - Држач за раце на подигање, монтиран во под. Health Craft, (2011), Р.T. Rail ${ }^{\text {TM }}$ Floor Mast [ONLINE]. Available at: http://www.healthcraftproducts.com/ptrailfloormast.htm [Accessed 01 May 13].

Слика 56 - Пример за држачи во боја. Извор: In-LawSuite.com, (2012), Bathroom Design For Mother In Law Suites [ONLINE]. Available at: http://in-lawsuite.com/mother-in-law-suite-bathroom-design/ [Accessed 09 May 13]. 113

Слика 57 - Портокалов држач за течен сапун. Извор: Toscana luce, (2013), G323/c/aR [ONLINE]. Available at: http://www.toscanaluce.it/images/grip/big/grip_5.jpg [Accessed 09 May 13].... 
Слика 58 - Портокалов држач за козметика до мијалник. Извор: Toscana luce, (2013), G242/c/aR [ONLINE]. Available at: http://www.toscanaluce.it/images/grip/big/grip_17.jpg [Accessed 09 May 13].

Слика 59 - Портокалов држач за козметика до туш. Извор: Toscana luce, (2013), 1311/C/AR [ONLINE]. Available: http://www.toscanaluce.it/images/accessori-doccia/big/accessori-doccia7.jpg[Accessed 09May13].

Слика 60 - Портокалова закачалка. Извор: Toscana luce, (2013), G204 [ONLINE]. Available at: http://www.toscanaluce.it/images/grip/big/grip_18.jpg [Accessed 09 May 13]. 115

Слика 61 - Држач за раце кој истовремено е држач за пешкир. Извор: Invisia Collection, (2012), TOWEL BAR with Integrated Support Rail [ONLINE]. Available at: http://www.invisiacollection.com/towelbar.html [Accessed 02 May 13].

Слика 62 - Седиште за капење кое се подига. Извор: Mobility Smart, (2012), Aquatec Sansibar Wall Mounted Shower Stool [ONLINE]. Available at: http://www.mobilitysmart.cc/aquatec-sansibar-wallmounted-shower-stool.html [Accessed 17 May 13].

Слика 63 - Лустер поставен над мијалникот. Извор: Sarah Richardson Design, (2013), Sarah's House for HGTV Bathroom [ONLINE]. Available at: http://www.sarahrichardsondesign.com/portfolio/project/sarahs-house/bathroom1 [Accessed 17 May 13].

Слика 64 - Местоположба на дополнителни светлосни извори за можна модификација со помал градежен зафат. Извор: авторот.

Слика 65 - Иверици поставени по должината на sидовите во просторот за дневен престој и спиење. Извор: авторот.

Слика 66 - Сугестии за можна модификација на простори во домот МТ со поголем градежен зафат изразени преку три варијанти. Извор: авторот.

Слика 67 - Врата со шибер систем. Извор: MarketKonekt, (2013), Шибер систем - АВАК 100 [ONLINE]. Available at: http://mk.marketkonekt.com/mk/shiber-sistem-abak-100?productid=vq6 [Accessed 17 May 13].

Слика 68 - Внатрешна sидна боја со фунгицидно својство. Извор: JУБ, (2013), Амикол [ONLINE]. Available at: http://www.jub.com.mk/mk-izdelki/mk-izdelki-za-problematicne-povrsine/mkamikol/?cat=3191 [Accessed 17 May 13].

Слика 69 - Конзолен мијалник со закосена долна страна за пристап на лице во инвалидска количка. Извор: Bobrick, W.E., 2007. Barrier-Free Washroom Planning Guide. Bobrick Washroom Equipment, Inc., BFPG-07, 1-24. 
Слика 70 - Зидни ламби до огледалото во тоалетот. Извор: Lamp Plus, (2012), Bathroom design with contemporary lighting [ONLINE]. Available at:

http://image.lampsplus.com/is/image/scenes/38589ven1.fpx?qlt=75\&wid=611\&hei=500\&fit=constrain

\&fmt=jpeg [Accessed 18 May 13]

126

Слика 71 - Насочено неонско осветлување над огледалото во тоалетот. Извор: Online Lighting,

(2013), Astro 0661 Tallin 600 Chrome Mirror Light [ONLINE]. Available at:

http://www.onlinelighting.co.uk/shop/bathroom-lighting/mirror-lights/astro-0661-tallin-600-chrome-

676221.html [Accessed 18 May 13]. 


\section{ДЕФИНИРАЊЕ НА ПОИМИ}

Визуо-просторна меморија (visuospatial memory) - Менталното визуелно претставување на предмети, места и патеки се нарекува визуопросторно процесирање (Marquardt, 2011).

Домашен карактер (homelike) - Простор кој содржи „домашни карактеристики“ и различни опции за земање учество во вообичаени секојдневни активности (Verbeek, 2011, р. 21). Спротивно на институционален изглед.

Домување со дополнителна нега (extra care housing) - Според Housing LIN (2008, p.1) домовите со дополнителна нега се „конщепт а не вид на домување“ наменети за социјално изнајмување или продажба на домови (куќи или апартмани како дел од комплекс, село, зграда и сл.) за самостојна нега на лица со различни примања.

Нега со потпомогнато живеење (assisted care или assisted living) - полунезависно домување чија програма нуди помош на станарите во изведувањето на секојдневните активности (Tapp-McDougall, 2010).

Негуватели (carers или caretakers) - поимот во текстот се однесува на стручните лица во домот кои се грижат за станарите. Кога се зборува за блиските на лицето со АБ (партнер, семејство) кои се грижат за нив во домашни услови ќе бидат нарекувани во текстот како „семејни негуватели“.

Паѓање (Fall) - „случка како резултат на која пациентот несакано се наоѓ во состојба на мирување на подот или на друга површина пониска од телото“ (Lamb et al. in BemisDaugherty \& Delaune, 2008, p.36)

Пристапен тоалет - тоалет за заедничка употреба дизајниран според стандардите за пристапност при употреба на тоалетите од лица со физички пречки кои при своето движење употребуваат инвалидска количка, бастун и друг вид на помагала. Во него станарите се придружувани од негувателите кои им асистираат во капењето.

Специјални станбени единици (Special care units) - во истражувањето овој термин ќе биде употребуван за именување на станбените единици наменети за лица со Алцхајмерова болест. 
Станари (residents) - се мисли на лицата кои живеат во домот за којшто станува збор.

Станиците за животни вештини (life skill stations) - Regnier и Denton ги опишуваат како „збир од мебел кој дефинира одредена животна вештина или активност“ (2009, р.175).

Физичка средина (physical environment) - сите физички елементи на опкружувањето во просторот и сите карактеристики на дизајнот во ентериерот 


\section{КРАТЕНКИ КОРИСТЕНИ ВО ТРУДОТ}

АБ - Алцхајмерова болест

MT - домот Мери Терзиева во Скопје

VC - домот Villa Colombo во Торонто

HН - домот Humber Heights во Торонто 


\section{1. ВОВЕД}

\section{1 Деменција}

„Деменичјата е назив за група од симптоми кои вклучуваат прогресивна загуба на мисловната функиија, вклучувајки загуба на меморијата и на други когнитивни способности. “ (Riverol и López, 2011, p.1). NICE и SCIE (2006) го опишуваат развојот на деменцијата како постепена појава на неколку или на сите наведени симптоми: губење на меморија, ослабнување на говорната способност, дезориентација, промени во карактерот на лицето, потешкотии при изведување на секојдневните активности, негрижа за себе, психијатриски симптоми (како на пример, апатија, депресија и психоза) и некарактеристично однесување (како на пример, агресивност, несоница или недостојно однесување).

Постојат неколку причинители/болести кои создаваат симптоми на деменција. Grand et al. (2011, p.126) издвојуваат четири основни класификации на причинители, дефинирани според клинички и истражувачки критериуми: „1) Алихајмерова болест,

2) васкуларна деменција, 3) фронтотемпорална деменција и 4) деменщија со луиеви тела или деменција со Паркинсонова болест. “ Алцхајмеровата болест (АБ) е најчеста форма на деменција кај старите лица (Ferri et al., 2005; Riverol и Lopez, 2011) и според податоците на Agency for Healthcare Research and Quality (in Williams et al., 2010, p.13) „опфаќa 60 до 80\% од случаите на деменција“. Поради нејзината честа појава, АБ е одбрана како тема на овој труд.

\section{2 Алцхајмерова болест}

Алцхајмеровата болест е дефинирана од страна на Biran et al. (2009, p.1) како „прогресивна невродегенеративна болест“ која се одликува со постепено нарушување на сеќавањето и когнитивните процеси кои значително ја ослабнуваат човечката способност за секојдневно функционирање. Иако засега нема лек за АБ, постојат низа третмани и стратегии за лицето со АБ и неговите блиски кои можеби содржат потенцијал во променување и/или успорување на развојот на болеста. Достапни се многубројни 
фармаколошки, но и нефармаколошки начини за третирање на нарушувањата предизвикани од болеста. Како позначајни нефармаколошки третмани Brawley (2006, p.29) ги издвојува „бихевиоралните, психосочиолошките и просторните пристапи, кои исто така може да бидат и обединети во кохерентен третман“.

Оној пристап или третман кој е од интерес за овој труд е просторниот. Целта за истражување на возможните просторни пристапи/третмани е да се овозможи подолга самостојност на лицето со АБ и полесно справување со нарушувањата кои пречат во совладување на просторот. Со разбирање на нарушувањата и промените кои се случуваат со развојот на болеста, може да се промени физичката средина во која лицата со АБ живеат и да се приспособи кон новата состојба во која овие лица неизбежно ќе се најдат.

\section{3 Стадиуми на развој на Алцхајмерова болест}

Развојот на АБ се проследува низ три стадиуми, чијшто развој Neno и Heath (2007, p.211) го опишуваат на следниот начин:

„Во раниот стадиум на болеста доминантни се потешкотиите при сеќавањето“, што може да доведе до промени во карактерот на индивидуата. Подоцна, за време на вториот стадиум, „лицето со АБ може да доживее потешкотии во говорот, изведувањето на секојдневните активности и во препознавањето на лица, места и ситуации“. Во третиот стадиум, „лицето со АБ доживува сериозни потешкотии во сеќавањето, функционирањето и препознавањето на луѓе“. Исто така, во овој стадиум веројатно е да се појават и други потешкотии како на пример при движењето или користење на тоалет, што значи дека постепено стануваат зависни од негувателите во изведување на секојдневните активности (Neno и Heath, 2007). Grant at al. (2011) накратко објаснува дека раниот стадиум на болеста лицето со АБ започнува со запоставување на себеси преку исхрана, лична хигиена и извесни домашни задачи, меѓутоа до доцниот стадиум болеста прераснува во запоставување на основните активности од секојдневието што резултира со очигледни проблеми во облекувањето, хранењето и капењето. 


\section{4 Нарушувања предизвикани од АБ кои влијаат врз односот со опкружувањето}

Како основен принцип за секој објект наменет за употреба од лица со АБ е дека дизајнот треба да компензира за нарушувањата произлезени од болеста, бидејќи тие преминуваат во инвалидитет само тогаш кога компензацијата е неуспешна. (Utton, 2009) Во следниот текст ќе се направи обид да се набројат и опишат нарушувањата кои се јавуваат во првиот и вториот стадиум на АБ. При тоа, ќе бидат разгледани само оние нарушувања кои можат да бидат компензирани со помошта на дизајнот во ентериерот. Неопходно е да се истакне дека од ова истражување исклучени се симптомите кои се појавуваат само во третиот стадиум на АБ и оние кои не се засегнати со планирањето на просторот, како што се на пример депресија, параноични претстави, илузија, халуцинации, агресивност, неподвижност, итн.

За прикажување на карактеристичните промени кои се појавуваат кај лицата со АБ со развојот на болеста употребена е поделбата на Utton (2009, р.380) според која нарушувањата се делат на:

1) Физички нарушувања,

2) Нарушување на видот,

3) Нарушуване на слухот,

4) Когнитивни нарушувања.

Користејќи ги описите на Grand et al. (2011) за нарушувањата кои се појавуваат кај лицата со АБ ќе биде разгледана следната поделбата на нарушувањата:

\section{1) Физички нарушувања}

Grand et al. (2011) истакнуваат дека деменцијата и АБ често предизвикуваат неподвижност, опадната физичка кондиција, загуба на тонус на мускул, слаба координација и сл. Авторите понатаму се согласуваат дека овие појави го доведуваат лицето во поголема опасност од паѓање и повреда. Како неопходна безбедносна реакција на тоа би била адаптирање на околниот простор на лицето со АБ при „употребата на помошни средства за изведување на активности како употреба на тоалет, исхрана, 
облекување“ (Grand et al., 2011: страна?) и други активности од секојдневието на индивидуата.

Елементи од ентериерот кои се поврзани со физички нарушувања:

Поради горенаведените физички нарушувања ентериерот треба да биде поткрепа за лицата со АБ да можат безбедно да ги извршуваат своите секојдневни активност и покрај своите физички ограничувања.

\section{Како последица на потребата од помошни средства во движењето просторот треба да биде проектиран во согласност со правилниците за непречен пристап.}

\section{2) Наруиување на видот}

Познато е дека со стареењето кај луѓето се појавуваат одредени проблеми со видот без разлика дали имаат АБ и други видови на деменција. Меѓутоа, логично е да се претпостави дека лицата со АБ потешко се справуваат со тие проблеми. Можеби една од разликите во справувањето лежи во заклучокот на Tales et al. (2005: страна?) каде е наведено дека ,лицата со АБ не се цеелосно способни да ги употребуваат визуелните знаци како предупредување“, поради што нарушувањето на видот би било уште поопасно кога лица имаат АБ. Дополнително на тоа, способноста на лицата со АБ за визуелно препознавање е нарушена поради, како што објаснува McNaughton et al. ( Alescio-Lautier et al., 2007: страна?), атрофирањето на хипокампусот во раниот стадиум на болеста кој има „суштинско значење при употреба на просторната меморија“.

Armstrong (2009) ги издвојува следните проблеми поврзани со нарушување на видот: острината на видот, восприемање на боја и видно поле, промена во чувствителноста на контрасти, нарушување на комплексни визуелни функции како што се читањето, просторното восприемање и идентификувањето на предмети. Понатаму Armstrong предупредува дека поголем број од овие промени имаат конфликтни податоци во 
литературата и дека ниту една окуларна или визуелна карактеристика не може да биде оценета како конкретна дијагноза на АБ.

\section{Елементи од ентериерот поврзани со нарушување на видот:}

\section{Функциите кои зависат од видот се главно засегнати од слабо или нерамномерно осветлување и појавата на одблесок.}

\section{3) Нарушување на слухот}

Во еден често цитиран статистички преглед спроведен од Националната академија на старото општество (National Academy on an Aging Society, 1999) истакнато е дека дури 45\% од американското население со проблеми со слухот има над 65 години. Оттука може да се заклучи дека како што нарушувањето на видот се појавува во нормалниот процес на стареење, на истиот начин може да се појави и нарушување на слухот.

Brawley (2006) образложува дека нарушувањето на слухот влијае на квалитетот на животот на индивидуата и може да доведе до депресија, нарушување на когнитивните функции, ослабната мобилност и социјална изолираност. Покрај тоа што лицата кои доживуваат ослабнување на слухот можат да користат слушни апарати и да извршат хируршки зафати, задачата на дизајнерите и архитектите е да откријат кои аспекти од загубата на слухот може да бидат помогнати од средината во која лицата живеат.

Бидејќи домовите наменети за грижа на лица со АБ истовремено претставуваат и работни средини за негувателите, но и поради надворешни фактори, присутно е одредено количество на бучава во просторот (АКЕ, 2011). Присуството на несакана бучава во домовите неопходно е да се контролира, бидејќи како што не опоменуваат Bharathan et al. (2007, p.1) „преголемата количина на бучава може да му наштети на човековото здравје и особено на постарите лища во слаба ментална и психолошка состојба“. Штом бучавата им пречи на лицата кои немаат проблеми со слухот, тогаш само може да претпоставиме колку може да ги иритира и збунува лицата со АБ кои можеби не се свесни за потеклото на бучавата. 


\section{Елементи од ентериерот поврзани со нарушување на слухот:}

\section{Покрај градежните мерки за акустична изолација, постојат разни стратегии за уредување на ентериерот кои можат да го намалат присуството на несакана бучава. Со цел да се применат тие стратегии, треба да се откријат потенцијалните извори на бучава во просторот наменет за лицата со АБ.}

\section{4) Когнитивни нарущувања}

„Целта на употребата на просторот како нефармаколошки третман за АБ е навидум едноставна - да се создадат позитивни емоџии и да се задржат што е можно подолго. Архитектите и дизајнерите знаат дека тоа е возможно меѓутоа за да го направат тоа успешно, треба да научат многу за когнитивните нарушувана.“ John Zeisel (Brawley, 2009, p.29)

Zeisel и Brawley (Brawley, 2009) ги издвојуваат когнитивните нарушувања како едни од најважните нарушувања кога се планира уредување на ентериер наменет за лица со АБ. Според Grand et al. (2011) во когнитивни нарушувања спаѓаат: ослабнување на меморијата, неспособност за координирање на движењата, неможноста да се идентификуваат специфични објекти од средината, потешкотиите во фокусирањето и распределбата на вниманието, талкање, дефицити во активностите на секојдневниот живот, визуо-просторна дисфункција и други когнитивни нарушувања кои не се од интерес за ова истражување. Како што истакнуваат Silverberg et al. (2011), развојот на АБ најчесто започнува со ослабнување на сеќавањето, но подоцна ги засегнува сите когнитивни функции.

Според резултатите од истражувањето од 1993 на National Commission on Sleep Disorders Research (Brawley, 2006, p.47) кога луѓето се лишени од светлина нивниот внатрешен часовник станува неисправен. 65\% од лицата над 65 годишна возраст доживуваат проблеми со спиењето. Понатаму Brawley (2006, p.47) предупредува дека проблемите со спиењето кај лицата со деменција се едни од најтешките аспекти на болеста за негувателите. 


\section{5 Преваленција на Алцхајмерова болест}

Поради недостаток на статистички податоци за вкупниот број на лица во државата со поставена дијагноза АБ и број на станари со АБ во домовите за стари лица, за целите на истражувањето ќе се употребат статистички податоци на други држави како и податоци за старото население во РМ чиј пораст би требало да индицира пораст и во бројот на лицата со АБ.

Според пресметките и проекциите на Обединетите нации (United Nations, 2009, p.10), „секое седмо лище во светот е старо лище со возраст над 60 години“. Според истите податоци, се очекува „до 2050 година, секое петто лище да биде старо лище, со возраст над 60 години, а во 2150 година, секое трето лице да биде со возраст над 60 години“. Податоците од 2007 година на Brookmeyer et al. (Most, Scheltens и Van Someren, 2010) покажуваат дека „вкупно 27 милиони лиц̧а во светот биле дијагностицирани со Алихајмерова болест, а до 2050та година се очекува бројот да се зголеми до четири namu“.

\section{6 Предмет и цел на истражувањето}

Предмет на оваа студија е внатрешното уредување на домовите за згрижување на лицата во првиот и вториот стадиум на АБ со цел да се:

- Утврди како кон овој аспект се пристапува во Република Македонија,

- Утврди како кон овој аспект се пристапува во поразвиените средини во светот по примерот на Канада,

- Разбере интеракцијата помеѓу внатрешното уредување на просторот и лицата со АБ со цел да се препознаат карактеристиките на ентериерот кои можат да им помогнат на лицата со АБ во секојдневното функционирање,

- Извлечат поуки за тоа која е најдобрата пракса во внатрешното уредување на домовите за згрижување на лицата со АБ, а преку кои се поддржува и промовира нивната самостојност. 


\section{2. ПРЕГЛЕД НА ЛИТЕРАТУРА}

Куќите и становите вообичаено не се проектирани со цел да бидат користени од страна на лица со когнитивни нарушувања освен кога тоа е едно од барањата наведени во на проектната задача. Човекот со стареењето најчесто се здобива со одредени физички или когнитивни нарушувања. Кога тоа ќе се случи, додека човекот се менува, домот во кој живее останува непроменет и карактеристиките на просторот повеќе не ги задоволуваат потребите на старо и изнемоштено лице. Одовде и потребата за користење на услуги од видот на: вселување во дом за нега на стари лица, модифицирање на станот според нормативите за лица со пречки во помнењето и мобилноста, или користење на јавна услуга за домашна нега.

\section{1 Типологија на домови со нега за лица со Алцхајмерова болест}

Покрај видовите на нега кои лицето со АБ може да ги добие во својот дом, постојат неколку опции за вселување во дом за нега. Додека на глобално ниво се случува пораст во бројот на лица со АБ, развиените земји го прошируваат обемот на типологијата и услугите кои различните видови на нега ги нудат. Mayo Clinic (2013) ги наведува следните видови на нега за лица со АБ:

- Домови со потпомогнато живеење (“Assisted living”),

- Домови со специјализирана нега за лица со деменичја ("Specialized dementia care facilities”),

- Домови со медищинска нега (“Nursing homes”).

\section{Домови со потпомогнато живеење}

Дефиницијата за потпомогнато живеење на Mayo Clinic (2013, website) кажува дека овој вид на домување е наменет за лица коишто „имаат потреба помош при изведување на лична нега и секојдневни активности, но немаат потреба од специјализирана медицинска нега“. Според Assisted Living Federation of America (2009, website) овој вид на домување е наменет за ,лиц̧а со проблеми со помнењето, мобилност, лицุа со 
Алихајмерова болест“" и други видови на попречувања за кои лицето има потреба од помош при изведување на секојдневните активности.

\section{Домови со специјализирана нега за лица со деменција}

Домовите со специјализирана нега за лица со деменција, или накратко „домовите за лица со пречки во помнењето“ како што ќе бидат нарекувани во оваа студија, содржат специјално уреден простор за специфичните карактеристики на болеста (Mayo Clinic, 2013).

\section{Домови со медицинска нега}

Овде најчесто се сместуваат дементни лица со дополнителни болести кои имаат потреба од 24 часова нега од медицинско лице (Alzheimer’s Society, 2012).

Дефинициите на различните видови на нега честопати се многу слични и тешко е да се воочи разликата само со разгледување на дефинициите. Најчесто домовите се разликуваат помеѓу себе според програмата за нега која ја нудат што најверојатно често претставува одлучувачки фактор при изборот на домот.

\section{2. Можности за нега на лица со АБ во Р. Македонија}

Според Центарот за истражување и креирање политики (2009), можните општински услуги на нега во РМ може да се поделат на институционални и вонинституционални мерки на општинско ниво. Во групата на институционални мерки спаѓаат „посmакутната нега во болнищите, дневни одделенија во болнищите, хосписи, домашно лекување и патронажна служба“, а во групата на вонинституционални мерки спаѓаат разни дневни клубови, центри за нега, телемедицина и слично (Центарот за истражување и креирање политики, 2009: 6-7).

Во Република Македонија, освен опцијата за домашна нега, лицата со АБ може да бидат сместени во дом за стари лица, без специјализирана нега за лица специфичните потреби на 
овие лица. Нема податоци за тоа како останатите домови за стари лица го третираат престојот во заедничките простори. Од непознати причини оваа опција не е наведена во анализата на Центарот за истражување и креирање политики (2009). Центарот ја прави поделбата врз основа на мерки во здравствениот систем.

Во својата статија, Талеска (2012) открива дека во Република Македонија има 4 јавни и 12 приватни домови за стари лица. Како што може да се забележи во табеларниот извештај за капацитетот на приватните домови прикажан на Табела 1, МТ има најголем капацитет на сместување со своите 61 легла.

\begin{tabular}{|c|c|}
\hline \multicolumn{2}{|c|}{$\begin{array}{l}\text { Приватни лиценцирани установи вкупен капацитет } \\
339 \text { легла }\end{array}$} \\
\hline „Ваш нов дом“ - Скопје & 10 легла \\
\hline „Вита Ве“ - Скопје & 12 легла \\
\hline „Милица“ - Скопје & 39 легла \\
\hline „Панада“ ДООЕЛ - Скопје & 28 легла \\
\hline „Руски“ - Скопје & 30 легла \\
\hline „Геромедикал феникс“ - Скопје & 15 легла \\
\hline „Геронтос БМ“ - Скопје & 25 легла \\
\hline „Светла надеж“ - Скопје & 14 легла \\
\hline „Терзиева“ - Скопје & 61 легла \\
\hline „Жана Снежана“ - Неготино & 45 легла \\
\hline „Лабос“ - Скопје & 30легла \\
\hline „Жана C“، - Скопје & 30 легла \\
\hline
\end{tabular}

Табела 1 - Талеска (2012). Капацитет на приватни лиценцирани установи за стари лица. Нова Македонија, 22485 - 1 јануари 2012. Достапно на:

http://www.novamakedonija.com.mk/NewsDetal.asp?vest=12112935164\&id=9\&prilog=0\&set|zdanie=22485. Пристапено на: 21.06.2012.

Промените во физичките функции, менталната способност, животниот интерес и финансиската состојба се одлучувачки фактори во изборот на место и услуга за нега. Некои лица сакаат да останат во својот дом, меѓутоа оваа опција можеби не е реална за оние кои немаат кој да се грижи за нив и имаат потреба од постојана нега. Поради тоа, потребно е да се овозможи поголем избор на опции за домување и нега во РМ за да можат 
да бидат задоволени различните потреби за нега, буџетот и личните преференции на лицата со АБ и нивните семејства.

Во Националната стратегија за стари лица за периодот од 2010-2020 година спроведена од Министерството за труд и социјална политика на Р. Македонија (2010: 34), помеѓу мерките за подобрување на системот за социјална заштита на старите лица, е наведено „отварање на мали групни домови за стари лища со ментална или телесна попреченост, кои немаат соодветни услови за живеење во своето семејство“. До времето на пишување на овој труд не е забележана изградба на таков објект.

\section{3. Предност на живеење во дом за нега на лица со пречки во помнењето}

За лицата со деменција, домашната средина претставува позната територија на која тие се чувствуваат безбедно. Одлуката за преместување на лицето со АБ во дом е индивидуална, но зависи и од состојбата во која лицето се наоѓа. Иако модификациите во домот и патронажните служби се од значителна помош за семејните негуватели, кои во овој случај се партнерот на болното лице или некој друг член од семејството, тие и понатаму го носат најголемиот товар. Сепак, како што велат Hoof и колегите (2010: 206) „модифицирањето на домашната средина е привремено решение на проблем кој е во nopacm.“

NICE и SCIE (2006: 94-95) инсистираат дека старите лица со деменција многу често имаат дополнителни медицински проблеми за кои е потребно често да бидат надгледувани. Додека дополнителните здравствени проблеми може да имаат лошо влијание врз квалитетот на животот на лицата со деменција и нивните негуватели „грижата за нив, особено во последниот стадиум на болеста, може да биде многу вознемирувачко искуство“ (NICE and SCIE, 2006: 95). Ова може да се издвои како една од причините за преместување на болното лице во дом за грижа. Покрај горенаведената причина која индицира оптоварување на домашниот негувател, Buhr, Kuchibhatla и Clipp ( во Grand, Caspar и Macdonald, 2011: 134-135) истакнуваат дека партнерот или семејството кое се грижи за лицето со АБ најчесто ги издвојува следните „главни причини за пренесување на 
блискиот во институционална нега“: потребата од искусни негуватели и од сѐ поголема помош, зачувување на здравјето на партнерот или семејството кое има улога на негувател и присуството на психолошки и бихевиорални симптоми.

Доколку, државата им овозможи на овие лица подобра средина за домување, која ќе ги задоволува основните потреби на лицата со АБ и во која семејството и потенцијалниот станар би имале доверба, тогаш таква одлуката за преместување во дом би се донесувала полесно. Сепак, како што заклучуваат Shelton и Lee (2010) по нивната споредба на лица во потпомогнато живеење и лица во домашни услови, престојот во дом со потпомогната нега може да создаде позитивни и значајни влијанија на когнитивните функции на лицето со АБ. 


\section{3. МЕТОДОЛОШКИ ПРИСТАП}

Во ова поглавје ќе бидат детално разгледани начинот на којшто е спроведено теренското истражување и дизајнот на студијата. Поделбата на ова поглавје е според изведбениот редослед применет во истражувањето, имено од избор на учесници во студијата, до преработка на податоци. Методот којшто беше одбран за изведба на истражувањето претставуваше комбинација од студија на случај и прегледување на достапна литература на темата од интерес.

\section{1 Селекција на случаите вклучени во студијата}

Студијата на случај беше спроведена во три домови со долготрајна нега на стари лица кои згрижуваат лица со АБ во првиот и вториот стадиум на болеста. Едниот од домовите се наоѓa во Скопје, Република Македонија, а другите два во Торонто, Канада. Трите домови се лоцирани во урбана населба на главните градови.

Домовите во Скопје беа главно селектирани во зависност од дозволата за пристап во објектот. Листата на лиценцирани домови во градот Скопје објавена од Талеска (2012) беше појдовен критериум за селекција на домови. Од наведените домови на листата беа издвоени оние кои имаат интернет страна на која може да се најдат повеќе податоци за домот. Потоа селектираните домови беа телефонски контактирани и изборот беше сведен на добивање на потврден одговор на следните две прашања: дали домот згрижува лица со АБ и дали домот овозможува пристап за снимање на просторот кој би го користеле лицата со АБ. Единствениот дом со потврден одговор на овие две прашања беше домот МТ.

Селекцијата за домовите во Торонто беше поразлична од онаа применета во Скопје, со оглед на тоа што во Торонто главно сите домови овозможуваат пристап за снимање со истражувачка цел и домовите кои згрижуваат лица со Алцхајмерова болест се многу повеќе на број. Според листата на домови со долготрајна нега на стари лица со деменција наведена на интернет страната на Toronto Dementia Network (2013), во Торонто има околу осумдесет вакви домови за нега. Поради тоа, селекцијата беше сведена на локацијата на домот во однос на пристапност и близина на местоположбата на авторот за време на снимањето. 
За пореална и веродостојна споредба помеѓу домовите од двете земји беа издвоени неколку карактеристики на домот МТ кои беа приложени како услови за избор на домовите во Торонто. Бидејќи во домот МТ, според податоците од водичот, се згрижуваат лица во првиот и вториот стадиум на АБ, но понекогаш и лица во третиот стадиум во зависност од состојбата, како еден од предусловите за селекцијата на домови во Торонто беше земено згрижувањето на лица со АБ во прв и втор стадиум од болеста. Исто така, бидејќ́ станбените единици во МТ беа наменети за сместување на еден до два станари, при селекцијата се водеше сметка бројот на станарите сместен во станбените единици во домовите во Торонто да соодветствува со бројот на станари во домот МТ.

\section{2 Посета и снимање на домовите}

Општите податоци за домовите се прикажани во Табела 2. Од вкупно три домови, два се наоѓаа во Торонто, Канада и еден во Скопје, Република Македонија.

\begin{tabular}{|c|c|c|c|}
\hline & $\begin{array}{c}\text { The Village of } \\
\text { Humber Heights }\end{array}$ & $\begin{array}{c}\text { Villa Colombo } \\
\text { Home for the Aged }\end{array}$ & $\begin{array}{c}\text { Дом за стари лица Мери } \\
\text { Терзиева }\end{array}$ \\
\hline Локација & Торонто, Канада & Торонто, Канада & Скопје, Македонија \\
\hline Aдреса & $\begin{array}{l}2245 \text { Lawrence Avenue W, } \\
\text { Etobicoke, Ontario M9P 3W3, } \\
\text { Canada }\end{array}$ & $\begin{array}{c}40 \text { Playfair Ave, Toronto, M6B } \\
\text { 2P9, Canada }\end{array}$ & $\begin{array}{c}\text { ул. Владимир Комаров бб, } \\
1000 \text { Скопје, Република } \\
\text { Македонија }\end{array}$ \\
\hline $\begin{array}{l}\text { Дата на } \\
\text { nосета }\end{array}$ & 12.08 .2011 & 13. 08.2011 & 21.12 .2011 \\
\hline $\begin{array}{l}\text { Kanaџитет } \\
\text { (бр. станари) }\end{array}$ & 230 & 391 & 61 \\
\hline $\begin{array}{l}\text { Бр. на ССЕ } \\
\text { за лица со АБ }\end{array}$ & 39 & 88 & 0 (24 соби) \\
\hline $\begin{array}{l}\text { Снимени } \\
\text { содржини }\end{array}$ & $\begin{array}{l}\text { 1. еднокреветна ССЕ, } \\
\text { 2. двособна ССЕ со } \\
\text { брачен кревет, } \\
\text { 3. комуникациски врски, } \\
\text { 4. дневна соба, } \\
\text { 5. соба за активности, } \\
\text { 6. тераса }\end{array}$ & $\begin{array}{l}\text { 1. еднокреветна ССЕ, } \\
\text { 2. комуникациски врски, } \\
\text { 3. дневна соба, } \\
\text { 4.тераса }\end{array}$ & $\begin{array}{l}\text { 1. еднособна двокреветна } \\
\text { станбена единица, } \\
\text { 2.комуникациски врски, } \\
\text { 3.дневна соба на приземје }\end{array}$ \\
\hline $\begin{array}{l}\text { Линк до } \\
\text { website }\end{array}$ & $\begin{array}{l}\text { http://www.schlegelvillages.c } \\
\text { om/etobicoke }\end{array}$ & $\begin{array}{l}\text { http://www.villacharities.com/ } \\
\text { main.asp?View=Colombo }\end{array}$ & $\begin{array}{l}\text { http://dom- } \\
\text { terzieva.mk/page.php?page=2 }\end{array}$ \\
\hline
\end{tabular}

Табела 2 - Општи податоци за снимените домови за нега на лица со АБ. Извор: авторот.

По снимањето на просторот извлечени се позитивните аспекти присутни во секој дом поединечно. Спротивно на македонските домови, канадските се градени исклучиво според 
одредени правилници. Поради тоа ќе се направи споредба на македонските и канадските препораки за уредување на ентериери за непречен пристап на лица со пречки во движењето. Врз основа на овие анализи и споредби составени се препораки кои се однесуваат за домот МТ.

Покрај горенаведените начини на снимање на просторот изведена е и неформална опсервација на однесувањето на станарите низ просторот. Според Zeisel (2006) овој вид на опсервација е надополнување на спроведеното интервју бидејќи понекогаш станарите и вработените се навикнуваат на некои однесувања кои веќе не ги забележуваат а претставуваат значаен индикатор за нешто што е позитивно или негативно во ентериерот. Опсервацијата вклучува ниво на активности во домот забележани за време на снимањето отсуство на активности: спиење, седење без активност или социјална интеракција, шетање, гледање телевизија; ниско ниво на активности: пасивно учество во планирани активности; високо ниво на активности: активно учество во активности, разговор со станар, персонал, посетител; други активности: вербална вознемиреност, физичка вознемиреност, агресивност.

Заклучокот од практичното истражување ќе биде извлечен на два начини: најпрвин ќе бидат извлечени поуки од разгледаните канадски примери на домови наменети за лица со АБ, за на крај да бидат изработени сугестии за можни интервенции за приспособување на просторот за употреба од лицата со АБ во домот МТ.

\subsection{1 Спроведен разговор со водичите}

Поради различните професионални искуства/позадини и функции на лицата кои овозможија снимање на просторот обидот да се состави унифициран прашалник кој ќе се примени во интервјуто со водичите беше неуспешен. За таа цел наместо преку анкетен

прашалник интервјуто се спроведе преку слободен разговор. Иако во спроведеното интервју не се говореше опширно за ентериерот, тоа помогна во откривањето на дополнителни податоци кои пак помогнаа во разбирањето на начинот според кој се одвиваат организацијата, персоналот, вклученоста на семејствата навиките на станарите и воопшто во разбирањето на овој вид на домување за лица со АБ. 


\section{A) Humber Heights}

За време на посетата на домот НН беше спроведено фотографско снимање на два вида на станбени единици (еднособна и двособна), дневната соба, неколку соби за активности, хоризонталните комуникациски врски и заедничкиот пристапен тоалет. Бидејќи во моментот на посетата станарите се наоѓаa во трпезаријата, тој простор не беше достапен за снимање поради заштита на личниот идентитет на станарите.

Во домот НН водич беше маркетиншкиот координатор на домот, D.W.. Cо неа беше спроведен разговор за организацијата и развојот на домот, функциите и содржините во просторот, активностите кои се извршуваат во и надвор од просторот и учеството на семејството на станарите за време на посетите. Од страна на менаџерот-водичот беа доставени нацрти за станбените единици на кои е наведена површината на единиците и предлог за распоредот на мебелот. D.W. (2011) даде согласност за фотографско снимање на просторот и за вклучување на собраните податоци за домот во истражувањето.

\section{Б) Villa Colombo}

Bo Villa Colombo водич беше г-ѓa M. која во моментот на посетата имаше улога на волонтер во домот. Неопходно е да се забележи дека водичот не беше медицинско лице и немаше стручно познавање за функциите и содржините во просторот, активностите кои се одвиваат во него и сите останати теми кои би го опишале просторот и престојот на станарите во него. Нејзиното познавање се базираше исклучиво на искуството стекнато за време на волонтерскиот период.

\section{В) Мери Терзиева}

За време на посетата во МТ водич беше Б.Г., медицинска сестра и менаџер на домот. Преку разговорот со г-ѓа Б.Г. се добија стручни податоци за состојбата на станарите во домот Мери Терзиева, општата медицинска состојба на лицата со АБ, животот на станарите во домот, како и бројните активности кои се спроведуваат во домот но и надвор од него.

\subsection{2 Фотографско снимање на објектите}


Фотографското снимање на трите објекти беше дозволено само во простори каде немаше присуство на станари за да се почитува правото на заштита на нивниот личен идентитет. Тоа предизвика големо ограничување во бројот на снимени содржини. Минималните снимани простори во сите домови се: најмалку една станбена единица, приватен тоалет, заедничка дневна соба, комуникациските врски во просторот и распоредот на претходно споменатите содржини.

Покрај фотографирањето во отсуство на станарите, гостите и вработените во домот, фотографиите беа прегледани за присуство на лични податоци поврзани со станарите. Личните фотографии на станарите во станбените единици, како и ознаките со нивните имиња закачени на влезните врати во станбените единици, беа преработени во компјутерски програм со цел да се прикријат лицата и имињата. Најголемиот број фотографии вклучени во ова истражување се изработени од авторот, со исклучок на неколку фотографии преземени од интернет страницата на домот.

Со цел илустративно да се прикаже распоредот на содржините во просторот прикажана е основата на катот кој делумно (како што е случајот со НН) или целосно (во случајот со Villa Colombo) е наменет за престој на лица со АБ. Основата на катот за нега на лицата со пречки во помнењето и потпомогнато живеење во НН беа добиени од Robert Anderson (Carson Woods Architects Limited) кој е еден од архитектите на објектот, откако беше лично контактиран преку електронска пошта. Меѓутоа, во реалност добиената основата се разликува од оригиналната основа која е приложена во текстот. Настанати се промени кои се наоѓаат главно во заедничките простории од одделот за лица со пречки во помнењето. Од тие причини, во текстот ќе се користат скици и дијаграми изведени од авторот врз основа на снимените податоци, фотографиите и личното сеќавање.

Секој од домовите вклучени во студијата на случај беа посетени еднаш и секоја посета се одвиваше во присуство на водич - лице кое имаше различна функција во трите домови и беше посочено од страна на домот. Датумите во кои беа посетени домовите се наведени во Табела 2, на стр. 24. Посетата на домовите траеше околу еден час, освен посетата на домот НН која траеше приближно два часа. 
Снимањето на домовите и процесот на изработка на студијата на случај се сликовито прикажани на Слика 1 и се состоеја од:

1) Спроведен разговор со лице во улога на водич за време на посетата,

2) Изработка на скици од станбените единици,

3) Фотографско снимање на просторот,

4) Визуелна опсервација на просторот и генералното однесување на станарите низ него,

5) Пополнување на евалуациски прашалник врз основа на сниманиот материјал и сеќавањето на авторот,

6) Преглед и анализа на добиените резултати,

7) Издвојување на поуки извлечени од резултатите добиени при евалуацијата, како и од прегледаната литература на темата,

8) Изработка на сугестии за модификација на домот МТ врз основа на извлечените поуки.

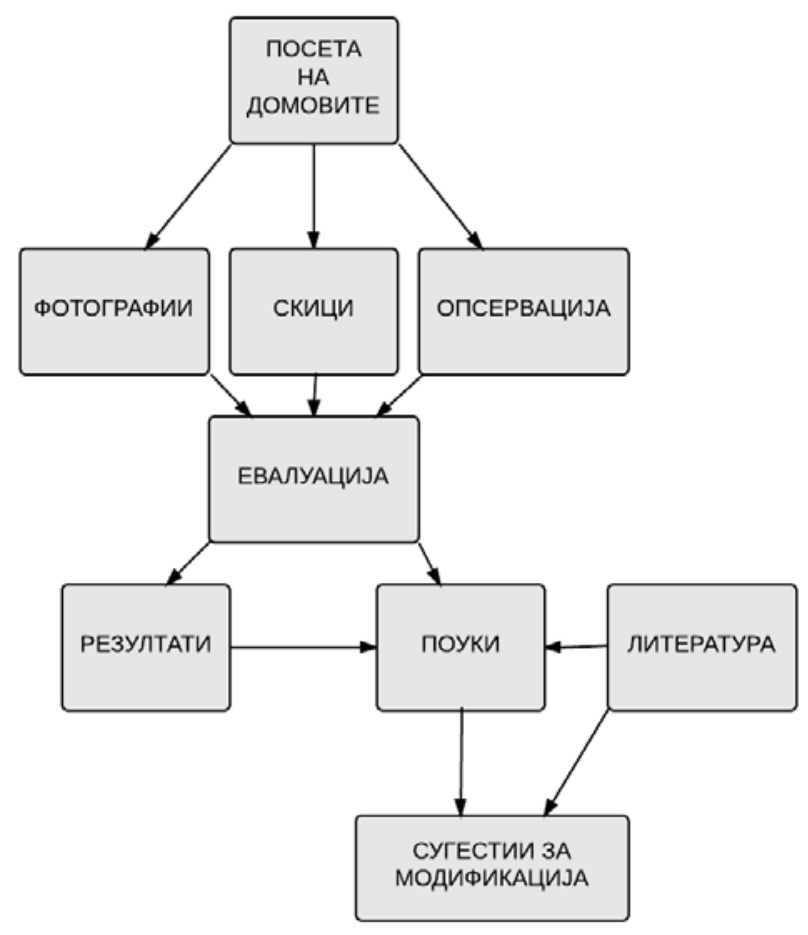

Слика 1 - Дијаграм за процес на изработка на студијата на случај. Извор: авторот. 


\section{3 Инструменти за евалуација на домовите}

За изведување на евалуацијата на домовите беа разгледани неколку достапни инструменти за мерење на квалитетот на ентериерот. Пронајдени беа следните евалуациски алатки кои се претставени накратко со нивните најосновни карактеристики:

1. Multiphasic Environmental Assessment Procedure (MEAP) - создадена од Моos и Lemke во 1996 година. Евалуацијата е составена од четири области за оценување, помеѓ кои и оценувањето на „физичките и архитектонските карактеристики“ (Fernández-Ballesteros, 2001, p.41). Во MEAР има вкупно 9 параметри според кои се оценуваат физичките и архитектонските карактеристики и се набројани од Fernández-Ballesteros (2001, p.42): „удобност, социјално-рекреативни помагала, протетички помагала, помагала за ориентација, безбедност, архитектонски избор, просторност, комфор за персоналот и општествена пристапност“.

2. Therapeutic Environment Screening Survey for NursingHomes (TESS-NH) Параметрите според кои евалуира TESS-NH се следните: независност во станбената единица, контрола на излез, одржување, чистота, безбедност, осветлување, простор/седење, познатост/домашен изглед, визуелна/тактилна стимулација, пристап до надвор, ориентација/ознаки и приватност. Како што може да се забележи од параметрите некои од нив се однесуваат на одржувањето на просторот и хигиената повеќе отколку на дизајнот на средината (цитат)[4]. Што значи дека дел од прашањата се однесуваат на раководството со домот, што не е тема на ова истражување. Исто така при TESS-NH недостига способноста за сумирање на резултати на крај од евалуацијата, освен што оценува со доделување на поени од 110.

3. Environmental Audit Tool (EAT) - создаден за оценување на квалитетот на средината за лица со деменција [8]. Оценувањето се изведува според 10 параметри: безбедност, големина, визуелен пристап, редукција на непотребен стимул, 
потенцирање на полезен стимул, снабдување со простор за талкање и надворешен простор, познатост, приватност, општествена поврзаност и домашни активност. Меѓутоа, одговорите на прашањата може да бидат само „да“ или „не“ со само неколку прашања кои можат да се одговорат со „нема одговор“. Оваа одлика на евалуацијата ја отфрла како опција за оценување на студијата од случај. За време на снимањето на домовите од оваа студија на случај, имаше карактеристики на домот кои не беа достапни за што ќе беше неопходна можноста за одговор на прашањата со „нема одговор“.

4. Evaluation of Older People’s Living Environments (EVOLVE) - Овој прашалник претставува алатка за евалуација на дизајнот во домовите за нега на стари лица и е наменет за употреба од страна на архитекти, сопственици на домови, истражувачи и индивидуални лица (Lewis et al, 2010). Тој е настанат како последица од тригодишното истражување спроведено од University of Sheffield и University of Kent (во партнерство со Department of Health Housing, Learning and Improvement Network и Elderly Accommodation Counsel). Првенствено, алатката била создадена за домување со дополнителна помош (extra care housing), меѓутоа авторите ја предложуваат и за евалуација на другите видови домување. EVOLVE ги испитува домовите и ги групира резултатите добиени од евалуацијата според следните параметри:

1. Личен избор

2. Достоинство и приватност

3. Комфор и контрола врз опкружувањето

4. Лична нега

5. Социјализација во објектот

6. Социјални контакти надвор од објектот

7. Пристапност

8. Физичка поддршка

9. Сетилна поддршка

10. Поддршка за деменција 
11. Здравје и заштита

12. Безбедност

13. Поддршка за персоналот

Lewis et al. (2010, p.37) го опишуваат EVOLVE како „збирка од прашалници,, кои служат за евалуација на просторот наменет за употреба од станари. Прашањата во евалуацијата се одговараат со избор на едно од следните: „да“, „не“, „не е во употреба“ или „нема податок“. Евалуацискиот прашалник за снимените домови од ова истражување беше одговорен по снимањето врз основа на забележаните податоци, изведените скици и фотографии, како и според сеќавањето на авторот. Од овие причини, во случај кога не беше снимен податокот за кој се однесува некое прашање или постоеше двоумење за точниот одговор, прашањето беше одговорено со „нема податок“. Lewis et al. (2010, p.37) понатаму наведуваат дека прашалникот може да се употреби од страна на „,архитект, домот за нега, комисионер, истражувач или лице кое сака да се всели во нов дом“. Оттука може да се заклучи дека нема конкретни ограничувања во однос на стручноста на лицето кое ќе го пополнува прашалникот и дека авторот може да го употреби за оценување на снимените податоци за домовите. Покрај оваа предност во употребата на EVOLVE прашалникот, Lewis et al. (2010, p.41) ја наведуваат и способноста за споредба на помали домови за нега на стари лица со поголеми.

За евалуација на ентериерот на трите домови беше одбран евалуацискиот прашалник EVOLVE. Употребата на евалуацискиот прашалник од лица со различна позадина, видот и различната големина на домови кои можат да бидат истовремено оценети со него, како и причината што резултатот всушност создава профил на домот а не претставува оценка за квалитет, го прават идеален за применливост во ова истражување. Дополнителен одлучувачки фактор за неговата употреба беше причината што прашалникот е неодамна обновен, како резултат на кое се очекува дека содржи значајни аспекти поткрепени од понови истражувања.

Откако ќе бидат одговорени сите прашања резултатите коишто произлегуваат од EVOLVE се прикажани во табели и хистограми со вредносни единици (бодови) кои ги оценуваат 
условите во објектот, но не станува збор за „,апсолутни бодови, туку создавање на профил на објектот кој ги покажува слабите и силните страни“ на снимените објекти (Lewis et al., 2010, p.41). Деталните резултати (во вид на табели и хистограми) кои што беа добиени од евалуацијата на секој од снимените домови во ова истражување, како и самите одговори од прашањата, ќе бидат приклучени кон Прилозите на стр. 138.

\section{4 Рамки на истражувањето}

Снимањето на домовите се одвиваше само во ентериерот наменет за користење од страна на станарите. Со цел да се добијат коректни резултати во сите три домови беа евалуирани само оние содржини кои се заеднички за трите домови, т.е. ходник, дневна соба и станбена единица со тоалет. Дополнителните содржини беа одделно евалуирани и нема да бидат вклучени во компаративната анализа на домовите.

Споредбата на добиените резултати од евалуацијата на домовите ќе биде прикажана табеларно во Поглавје 4 каде што ќе бидат вклучени вкупниот број на потврдно и негативно одговорени прашања, како и прашањата за кои немаше податок. Можните причини поради кои немаше податок за одредени прашања се следните:

- Прашањето не може да се приложи во состојбата во конкретниот дом,

- Авторот не е сигурен за одговорот на прашањето,

- Не беше достапна информацијата за конкретното прашање во времето на снимање на домот.

Вкупниот број на прашања во тематските единици кај секој од домовите е различен бидејќи во прашалникот на евалуацијата има одредени прашања кои доколку се одговорат потврдно се појавува нова нишка со тематски поврзани прашања. Поради оваа причина резултатите од евалуацијата беа пресметани и процентуално. Добиените податоци изразени во проценти се прикажани во графикони за полесно согледување на разликите. Графиконите содржат позитивен и негативен одговор на прашањата од евалуацијата на домовите поделени според тематските единки во прашалникот и изразени во проценти (\%). 
Главните резултати од снимањето ќе бидат внесени во споредбена табела со главни карактеристики на примерите од праксата, која ќе претставува помошно средство при деталната анализа во Поглавје 5, каде ќе бидат вклучени фотографиите и скиците од просторот и дополнителни податоци од прегледаната литература на темата. Во Поглавје 5 по пат на индукција ќе бидат разгледани добиените резултати од евалуацијата на домовите, при што позитивните аспекти ќе бидат извлечени како поуки што потоа ќе се пренаменат во сугестии за адаптација на домот МТ за потребите на лица со А.Б.. Во продолжение на поглавјето ќе бидат наведени поуките групирани според тематски единки логично подредени од авторот и секоја тематска единка ќе биде дискутирана врз основа на снимените карактеристики и достапната литература на темата од интерес.

Поуките ќе бидат ограничени само на оние простории за кои беше дозволено снимање за време на посетата на домовите, а тоа беа: по една станбена единица во трите домови со сите нејзини содржини (тоалет, место за спиење и место за дневен престој во единицата), дневна соба во домовите НH и VC, хоризонтални комуникациски врски и дополнителни содржини во домот НН - „станици за животни вештини“ (life skill stations, подетално на стр. 82). Дневната соба во домот МТ за време на посетата беше исполнета со станари поради што немаше услови за фотографски снимање како и за подолг престој во неа.

Состојбата на собата на станарите во МТ за време на снимањето беше двокреветна а просторот со којшто располага во услов на двокреветна станбена единица не дозволува интервенции коишто ќе ги вклучат најосновните поуки извлечени од студијата на случај и прегледаната литература. Дополнително на тоа, површината на двокреветната соба во МТ е нешто помала од површината на просторот во еднокреветните станбени единици во другите два домови. Поради овие две причини, предложените сугестии за модификација на домот вклучуваат елиминирање на еден од креветите во собата со што таа ќе стане еднокреветна станбена единица.

Ќе бидат изработени две групи на можни сугестии за модификација на станбените единици во домот МТ, сортирани во зависност од големината на промените треба да настанат: 
1. Сугестии за модификација на домот МТ со помал градежен зафат, и

2. Сугестии за модификација на домот МТ со поголем градежен зафат

При примената на модификациите со минимален градежен зафат може да се преземат и некои сугестии од предложените модификации со поголем зафат и обратно. Наведените модификации во Поглавје 6 не се конечни модификации кои засекогаш ќе ги променат условите за лице со АБ во средина наменета за стари лица без пречки во помнењето. Тие можат да претставуваат прв чекор кон подобрување на условите во средина која треба постојано да се надополнува во зависност од можноста на домот и врз основа на новите откритија од истражувањата.

\section{4. РЕЗУЛТАТИ}

\section{1 Опис на примерите од праксата}

\subsubsection{The Village of Humber Heights}

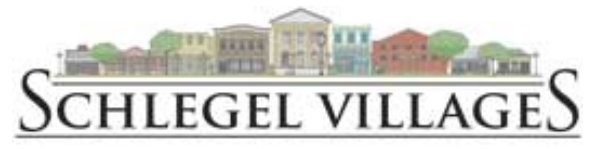

Домот НН е еден од дванаесетте домови на Shlegel Villages во Онтарио и се наоѓa во општината Etobicoke, во западниот дел од Торонто, Канада. Домот е отворен за јавноста во 2007 година. На местото каде што е изграден домот НН се наоѓa старото училиште HH Consolidated School, кое претставува културно-историски објект изграден во 1922 година. Поради неговата заштитеност со законот за културно наследство домот е изграден околу училиштето.

Домовите на Schlegel Villages се изградени со концептот на „селско живеење“ што е претставено преку „градскиот плоштад“ (атриум исполнет со улички со клупи и улични светилки, кафетерија, бербер, фризерски салон, и сл.) и „главната улица“ на приземјето како главни збирни места. Овој концепт има за цел да долови атмосфера на заедница и да 
предизвика собирање и социјализирање на станарите во атриумот. Поставеноста на „градскиот плоштад“ во атриумот на објектот овозможува користење на просторот и на дневната светлина во сите временски услови.

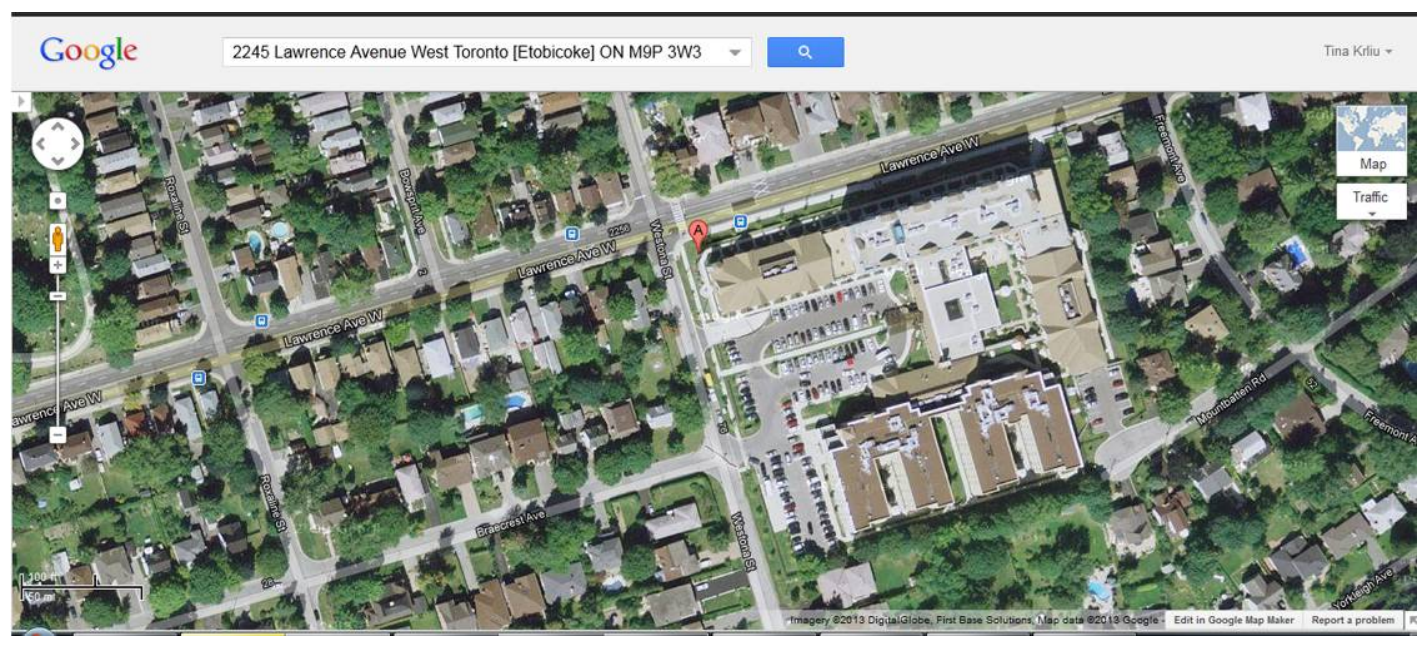

Слика 2 - Ситуација на домот НH. Извор: Google Maps (2013). Humber Heights Village Of, Etobicoke, Toronto. Available at: http://goo.gl/maps/gT80d [Accessed 12 May 2013].

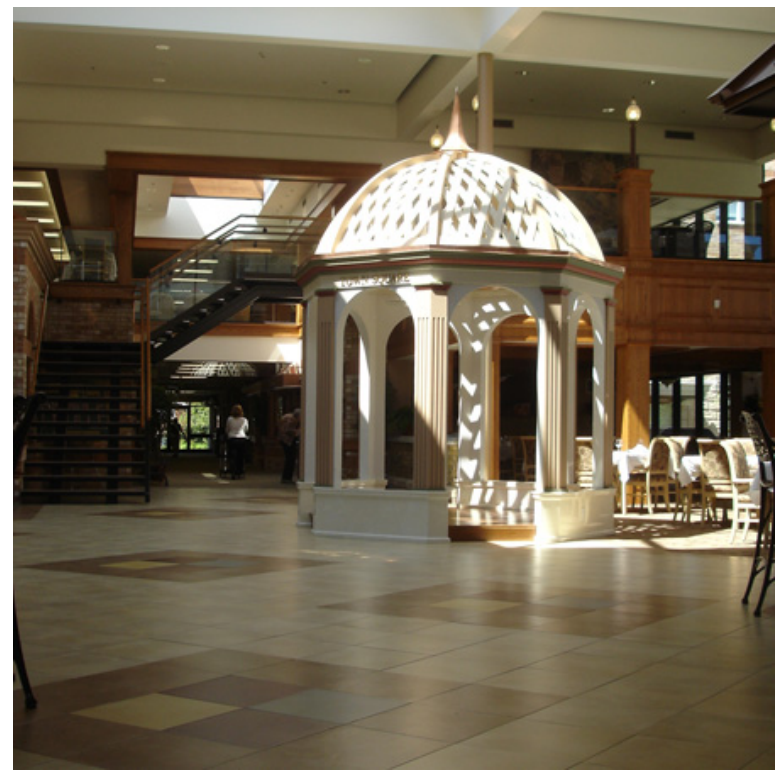

Слика 3 - Атриумот на приземјето во домот НН Извор: Concrete Floor Tek, (2013), The main lobby [ONLINE]. Available at: http://www.concretefloortek.com/photos/humber/vandel1.jpg [Accessed 20 December 12].

Лицата со АБ во домот НН имаат на располагање 39 станбени единици за нега за лица со пречки во помнењето на првиот кат. Покрај овој вид на домување на истиот кат се наоѓаат и 44 станбени единици за домување со физичка поддршка, додека приземјето се состои од 60 независни апартмани и 87 пензионерски апартмани. Во домувањето со нега 
за лица со пречки во помнењето се сместуваат лицата кои се наоѓаат во првиот и вториот стадиум на АБ. По преминот во третиот стадиум истите лица се преместуваат во домувањето со физичка поддршка или на палијативна нега надвор од домот.

\section{Содржсина и распоред}

За целта на истражувањето беше снимен одделот за нега за лица со пречки во помнењето (supportive/memory care) кое се наоѓa на првиот кат, заедно со одделението за потпомогнато живеење но сепак одделени со безбедносна врата која има дигитална брава со код. Содржините кои беа снимени за време на посетата во домот се: еднособна станбена единица (студио) со единечен кревет, двособна станбена единица со брачен кревет, ходници, дневна соба, семејна соба со кујна, заеднички тоалет со потпомагање, соба со „животна станица“, уметничко студио и тераса. Движењето низ просторот е на едно ниво, без денивелации и подигнати подови, што го олеснува движењето за лицата со пречки во видот и ја намалува веројатноста за паѓање на станарите. Позитивен аспект кој произлегува од формата на основата е тоа што двата ходници во кои се распоредени станбените единици се насочени кон заедничките простории. Ова создава можност станарите почесто да земаат учество во социјални активности.
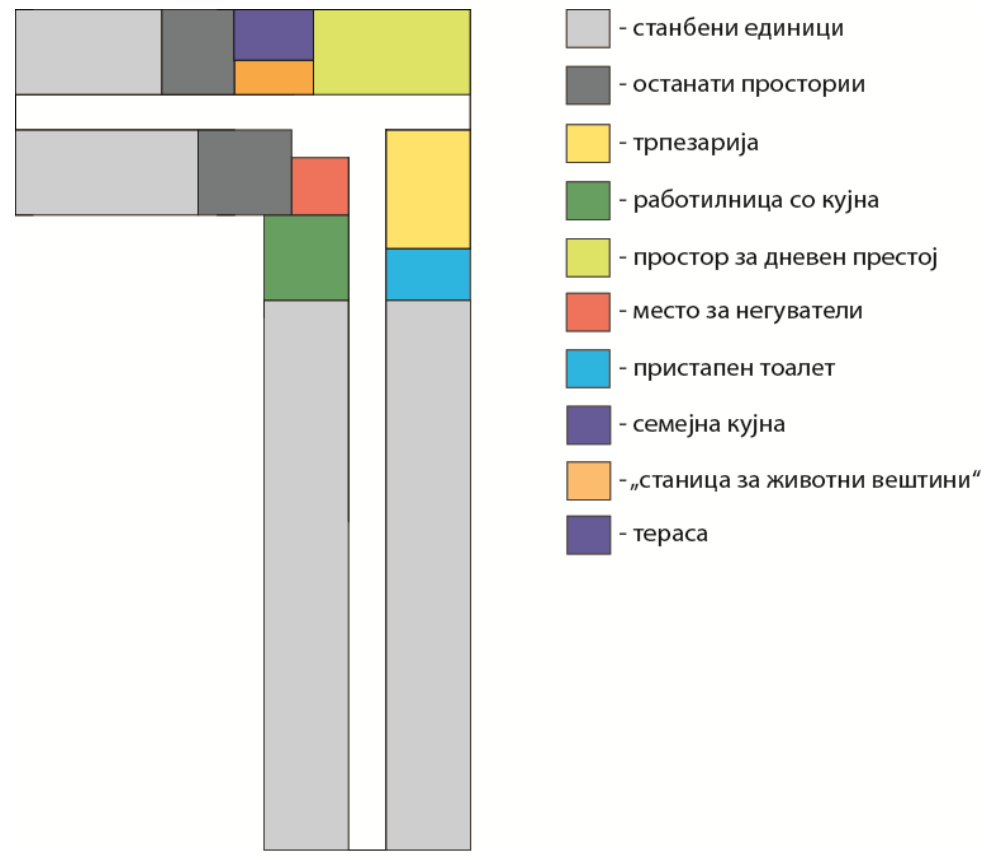

Слика 4 - Содржини во одделот за лица со пречки во помнењето во домот НН. Извор: авторот. 


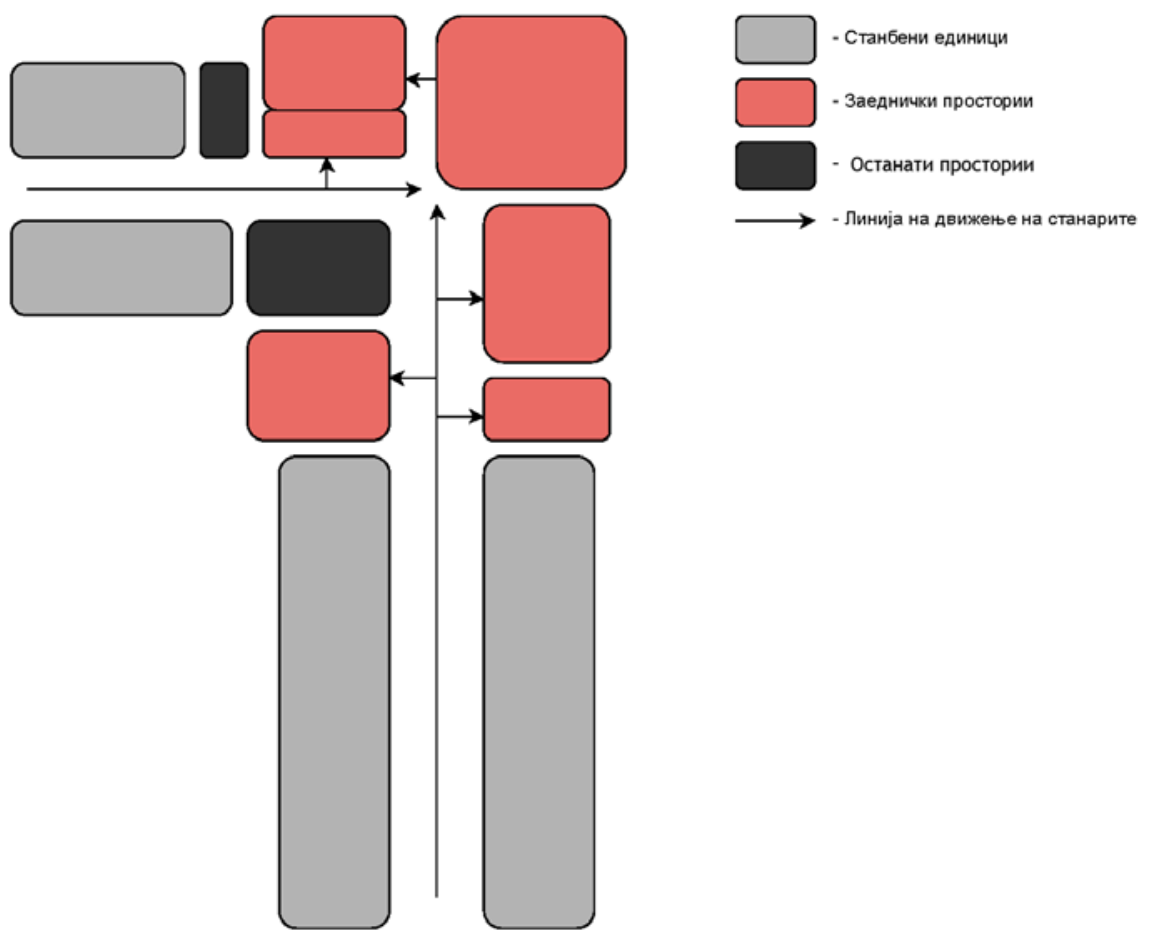

Слика 5 - Линија на движење на станарот низ содржините на домот НН. Извор: авторот.

\section{Станбени единицุи}

Станбените единици во одделот за негата за лица со пречки во помнењето во НН се два вида: еднособна станбена единица (студио) со единечен кревет и двособна станбена единица со брачен кревет. За време на посетата во домот беа снимени и двата вида, меѓутоа беа евалуирани само еднособните станбени единици.

\section{Еднособна станбена единцц - студио}

Површината на еднособните станбени единици изнесува околу $30 \mathrm{~m}^{2}$ во кои спаѓа и приватен тоалет. Овие станбени единици се наменети за лица со АБ или друг вид на деменција, кои се наоѓаат во вториот и третиот стадиум од болеста, сѐ додека не доживеат физичка повреда поради која би биле преместени во одделот за потпомогнато живеење или во палијативна нега надвор од домот. 


\section{5 sq.ft.}

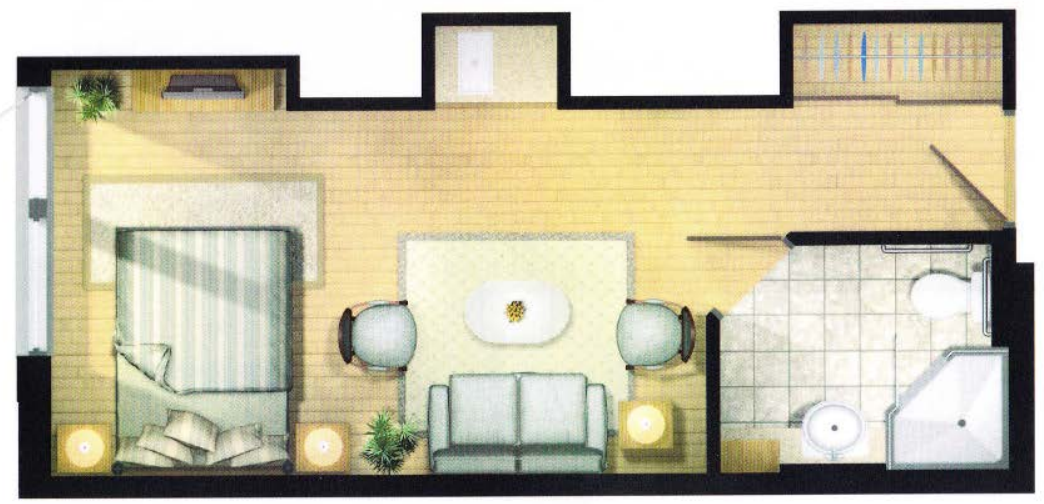

Слика 6 - Основа на студиото со кревет поставен до прозор. Извор: Schlegel Villages, (2012), Memory care [ONLINE]. Available at:

http://schlegelvillages.com/sites/default/files/Etobicoke/Living_Choices_floor_plans/Floor\%20plans325\%20sq\%20ft.jpg [Accessed 20 Dec 2012]

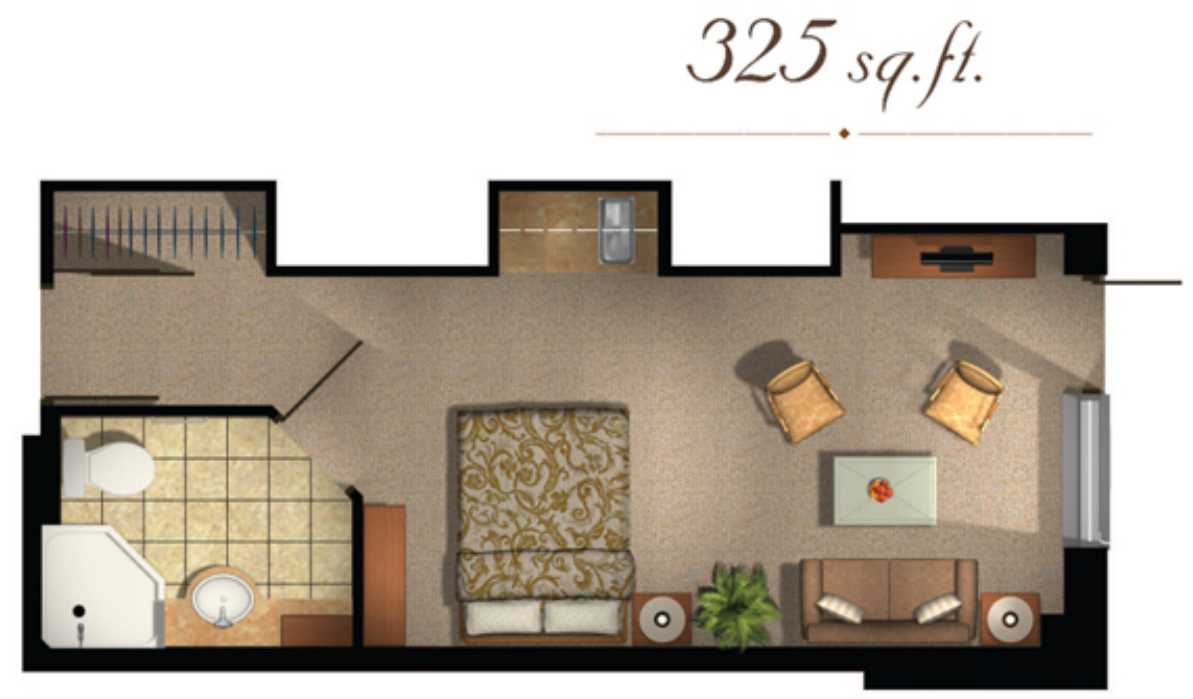

Слика 7- Основа на студиото со кревет поставен поблизу до тоалетот. Извор: Schlegel Villages, (2012), Memory care [ONLINE]. Available at:

http://schlegelvillages.com/sites/default/files/Etobicoke/Living_Choices_floor_plans/Floor\%20plans325\%20sq\%20ft.jpg [Accessed 20 December 12]. 


\section{Мебел во станбените единици}

Ненаселените станбени единици се празни со цел да се охрабрат новите станарите и нивните семејства во носењето на лични парчиња мебел кои ќе бидат препознатливи за лицето со АБ. Исклучок за тоа е креветот, бидејќи се работи за медицински кревети со вградени тркалца и адаптабилна височина. Доколку новите станари имаат потреба од мебел, домот ќе го обезбеди тоа за нив. Низ станбените единици отворите на вратите се доволно широки и отсутна е употребата на праг за слободно поминување на лицата со инвалидски колички или друг вид на помагала за мобилност. Додадени се неколку елементи во станбените единици кои помагаат во нивната адаптибилност за лица со пречки во движењето.

Од безбедносни причини станбените единици за лица со пречки во помнењето не содржат кујна. Како што велат Regnier и Denton (2009) кујната и тоалетот, како извори на вода, се најопасните делови од станбените единици бидејќи водениот под може да предизвика лизгање и паѓање при што станарите можат сериозно да се повредат. Дополнителна причина за опасност во кујната која ја наведуваат авторите е дека при подготовката на храна станарите може да се здобијат со повреди како изгореници и исеченици. 


\subsubsection{Villa Colombo}

\section{villa colombo}

Според менаџерот на домот VC, објектот бил изграден во 1976 година со донации на италијанската заедница во Торонто и е наменет за италијанската заедница во Канада. Во 1991 година на стариот објект бил дограден уште еден дел, кој во 2002 бил реновиран додека стариот дел го задржал стариот изглед. На петтиот и шестиот кат во стариот дел од домот се наоѓa одделот за долготрајна нега на лица со АБ и друг вид на деменција. На петтиот кат се сместени лицата во првиот кон вториот стадиум на болеста, додека на шестиот кат се лицата кои се наоѓаат во повисокиот стадиум на болеста. Според волонтерот и менаџерот на домот, петтиот и шестиот кат се идентични, но пристап за снимање на објектот беше овозможен само на шестиот кат.

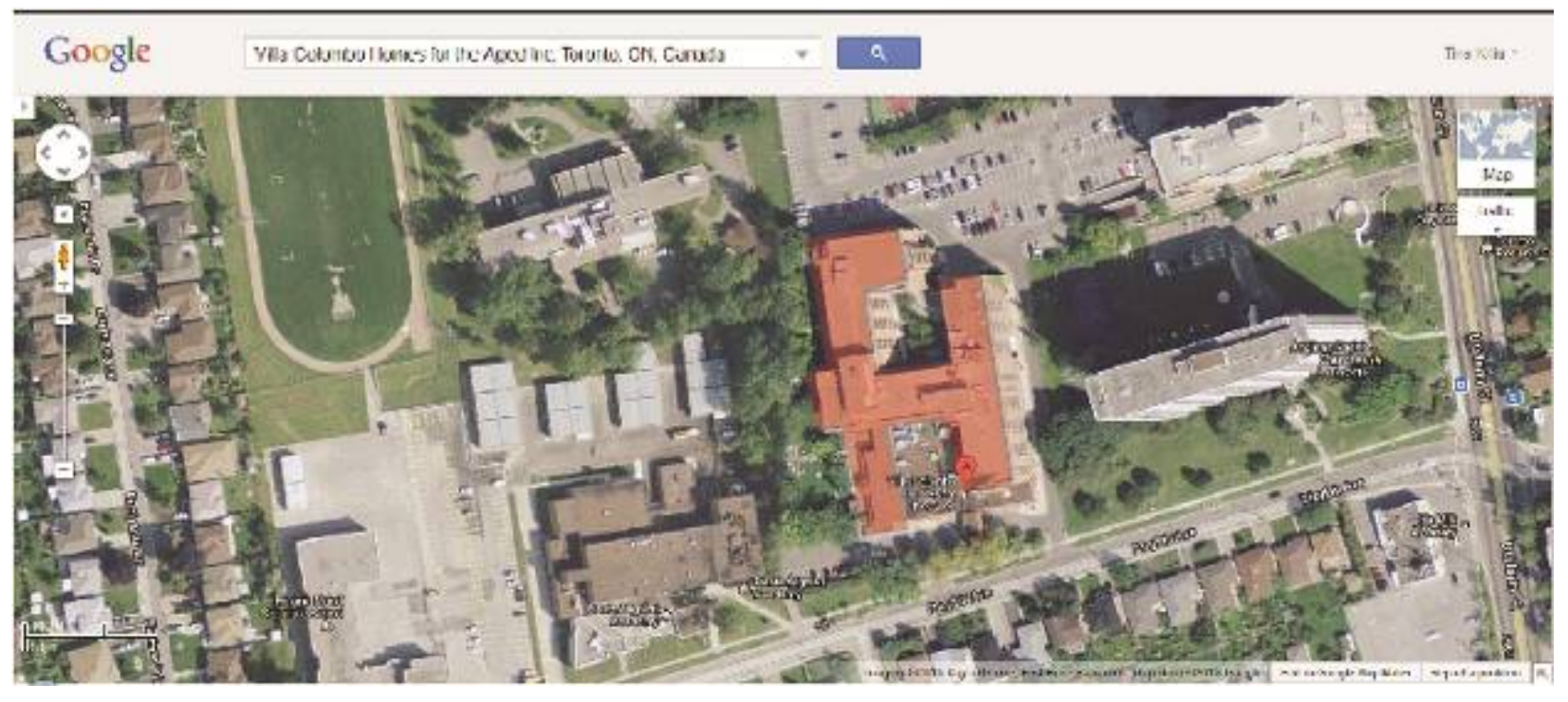

Слика 8- Ситуација на домот VT. Извор: Google Maps (2013). Villa Colombo Homes for the Aged Inc, Toronto. Available at: http://goo.gl/maps/c7M6B [Accessed 12 May 2013].

Она што е карактеристично за домот е посветеноста на конкретна етничка култура, што значи дека поголемиот број од станарите и негуватели се Италијанци (волонтер, 2011). Исто така, низ просторот беа забележани голем број на елементи и детали поврзани со италијанската култура, како на пример прикачени фотографии по sидовите низ ходниците, 
простор за изведување на католичка миса, место за настани и собири на италијанската заедница, итн. Сето ова му придава на просторот еден тематски културолошки контекст, при што дизајнот на ентериерот треба да ја претставува и отсликува италијанската култура. Успешноста во создавање на ваква средина зависи од изучувањето на културолошките вредности, норми и специфични ставови на етничката група (Valle, in Kane \& Houston-Vega, 2004).

Веднаш до влезот се наоѓа трпезаријата како и семејната трпезарија во која семејството на станарите може да дојде и да го прослави роденденот или едноставно да има приватна вечера. Просторот содржи кујна и 2 маси кои визуелно може да се поделат со лизгачки панели. Од оваа соба или директно од ходникот може да се излезе на терасата. Таму има дрвени маси и столици и висока ограда (регулирано од стандард). Семејната просторија е отворена и станарите слободно влегуваат во неа. Балконската врата се држи заклучена.

Тука собите се приватни и се состојат од кревет со шкафче врз кој за таванот е прикачен уред за подигнување. Наспроти креветот има ТВ и комода. Тоалетот се состои од WC шолја и мијалник и вратата е лизгачка. Гардероберот е мал и е вграден во sидот помеѓу спалната и тоалетот. Вратата од гардероберот се заклучува. Овој дел од домот има и дневна соба којашто се состои од двосед, фотелја, мини библиотека и ТВ уред. Вратите и мидот кој ги дели ходникот и дневната соба се стаклени со алуминиумски рамки. Наспроти дневната соба има кујна која е заклучена и може да се користи од персоналот и семејството на станарот. Домот има „snoezelen room“ - соба која се користи за стимулација на лицата со АБ, како и за лица со аутизам. Во оваа соба преку музика, светлина, допир, мирис и други начини на активирање на сите сетила, станарите се внесуваат со цел да се релаксираат и смират. Близу до влезот се наоѓа дневната соба која се состои од столици насочени кон ТВ уред. Од таму се стигнува до бањата во која персоналот им помага на станарите во капењето.Следна е собата за разни активности во која станарите можат да играат карти, игри или да цртаат.

Villa Colombo има два вида на станбени единици - полуприватни еднособни станбени единици и приватни еднособни станбени единици. Разликата е во тоа што полуприватните станбени единици имаат заеднички тоалет но одделни спални, а приватните имаат приватен тоалет. 


\subsection{3 Мери Терзиева}

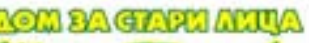

Mepu Tepzueba

Домот МТ бил основан во 1997 година и се наоѓа во мирен дел од скопската населба Аеродром. Станува збор за лиценциран приватен дом за стари и изнемоштени лица којшто е составен од два ката и содржи 24 двокреветни и еднокреветни соби со сопствен тоалет и систем за повик, кујна, трпезарија, соба за дневен престој, соба за активности, пристапен тоалет и двор (Слика 12). Според сопственичката на домот ,за 65 лицуа ито престојуваат во домот се грижи тим од 35 луѓе. Покрај секојдневна медицинска нега, тие (станарите) имаат посета од фризер, педикир, психолог, како и аниматори кои им помагаат да имаат поинтересно пладне“ (Тасев и Здравковска, 2011).

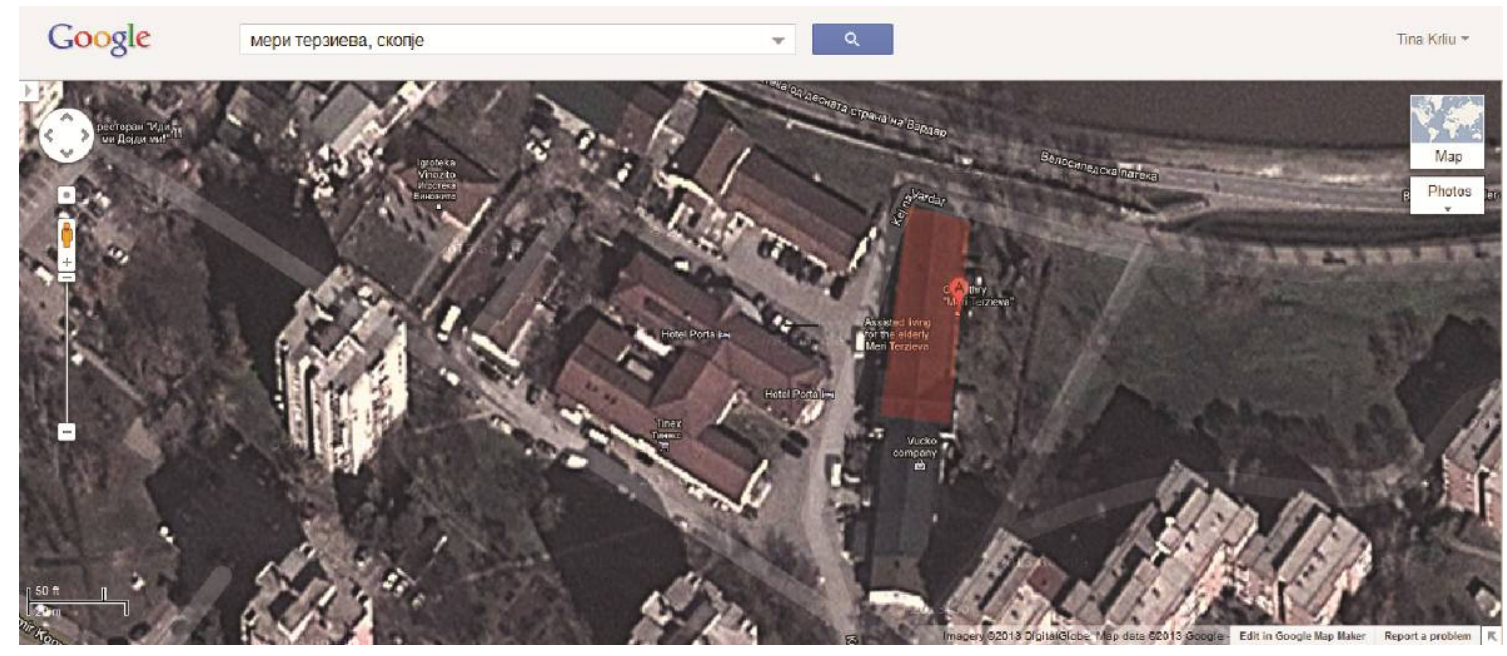

Слика 9 - Ситуација на домот МТ. Извор: Google Maps (2013). Geriathry "Meri Terzieva", Skopje. Available at: http://goo.gl/maps/Fvrll [Accessed 12 May 2013]. 


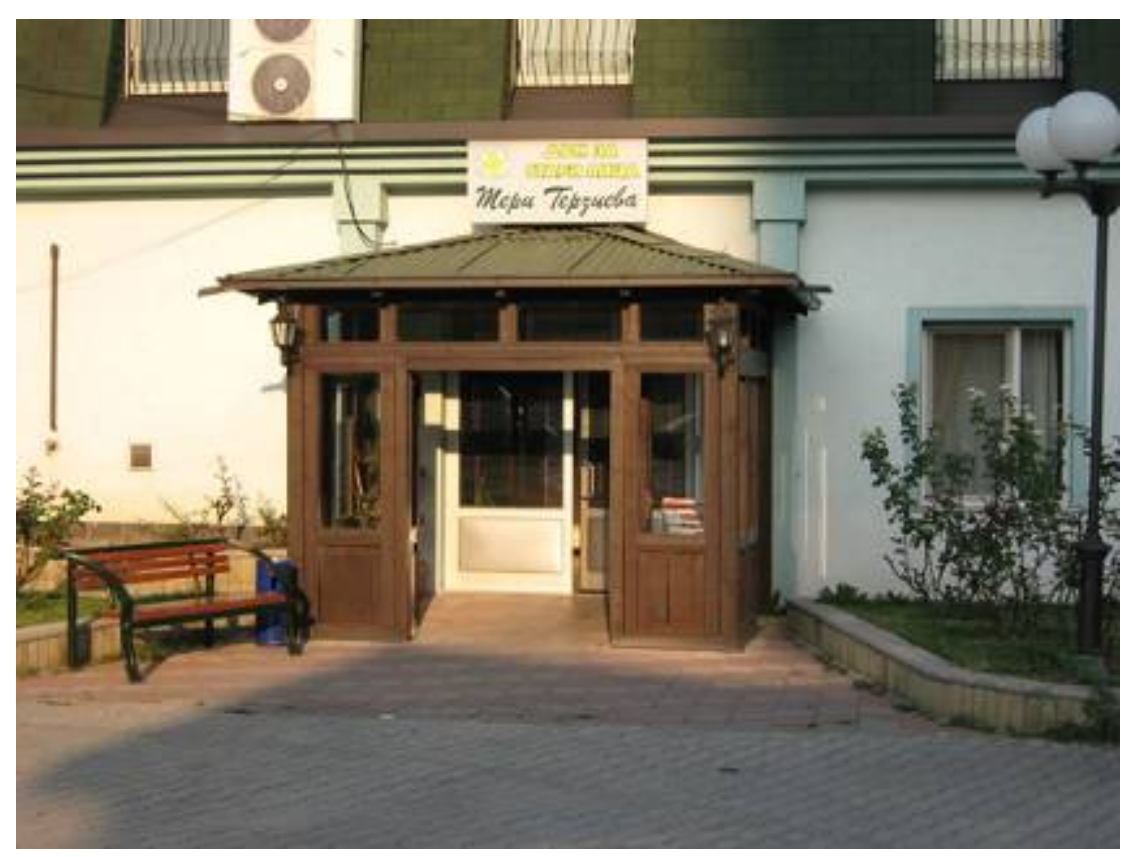

Слика 10- Главниот влез во домот МТ. Извор: Домот Мери Терзиева, (2009), Главниот влез во домот Мери Терзиева [ONLINE]. Available at: http://dom-terzieva.mk/images/kapacitet/04.jpg [Accessed 10 October 12].

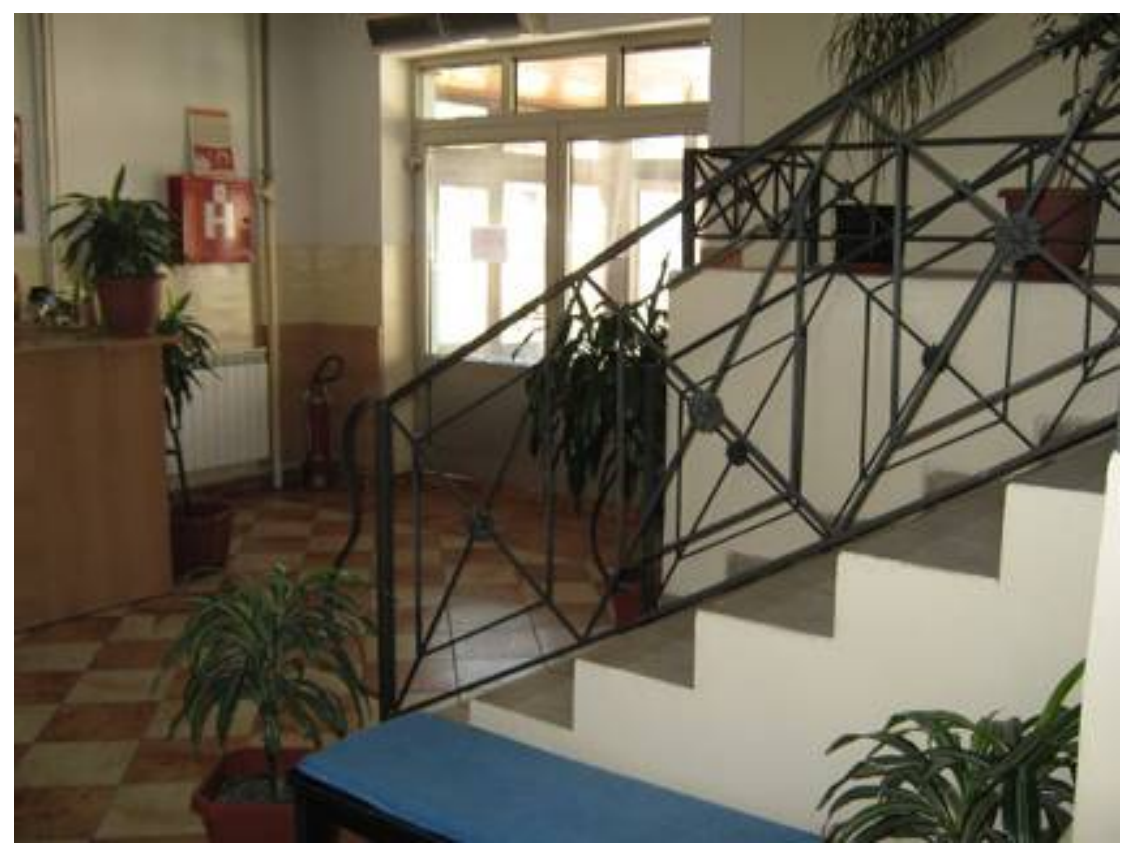

Слика 11- Скалишниот простор во МТ. Извор: Домот Мери Терзиева, (2009), Влезниот хол во домот Мери Терзиева [ONLINE]. Available at: http://dom-terzieva.mk/images/kapacitet/05.jpg [Accessed 10 October 12]. 


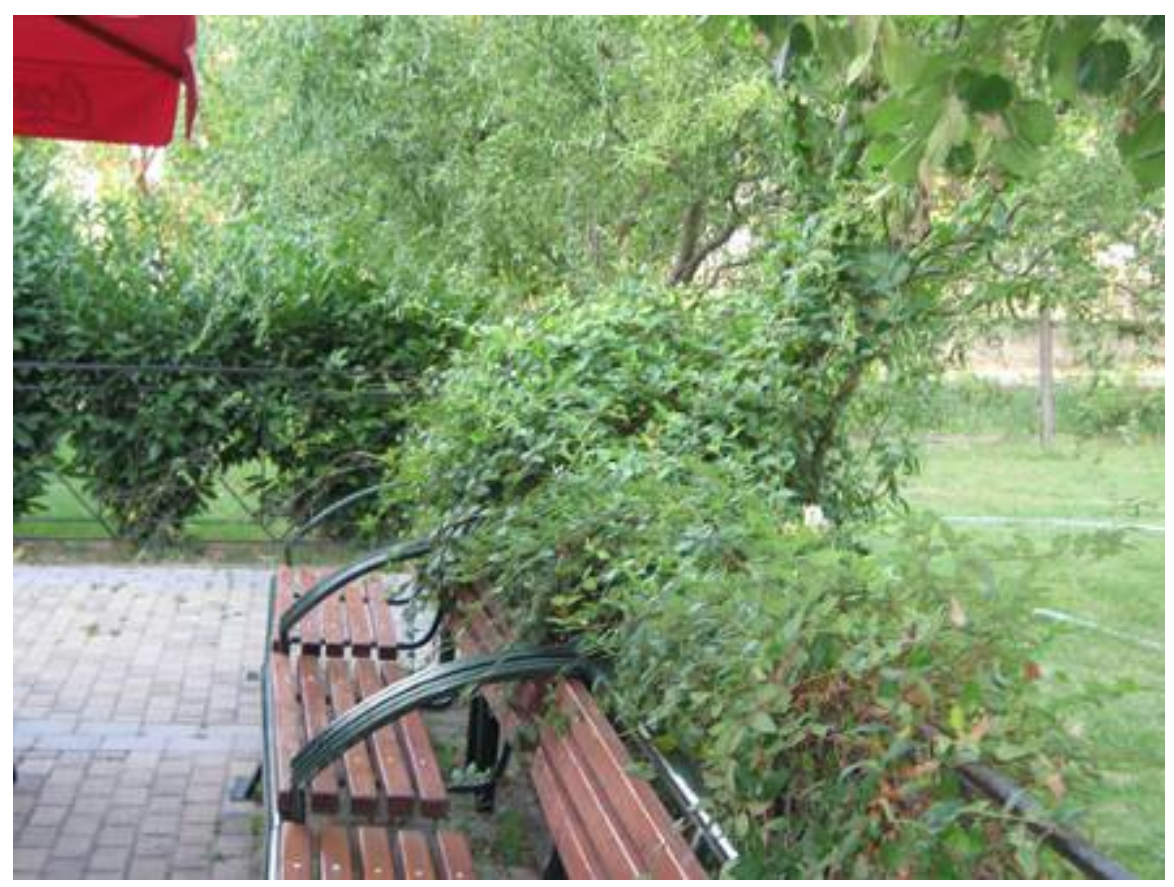

Слика 12- Дворот во МТ. Извор: Домот Мери Терзиева, (2009), Дворот на домот Мери Терзиева [ONLINE]. Available at: http://dom-terzieva.mk/images/kapacitet/03.jpg [Accessed 10 October 12].

Како што е наведено на интернет страницата на домот, тој е поделен на три дела:

1. Главна зграда со површина од 600м2 која содржи 24 соби, дневна соба, кујна, трпезарија, рецепција и тераса,

2. Споредна зграда со површина од 400м2 која е главно наменета за користење од персоналот и содржи канцеларија, перална, дневна соба и една соба,

3. Медицинска ординација „Гери Медикал“ со површина од 50м2 каде што станарите во секое време можат да добијат општи лекарски прегледи.

Карактеристично за домот е присуството на ординација во објектот, каде што во секое време на станарот може да му се овозможи медицинска помош или преглед, како и креативните работилници кои се одвиваат во домот. Здружението за унапредување на условите за грижа и сместување на стари и изнемогнати лица „ХУМАНОСТ“ заедно со организацискиот оддел на МТ изработиле проектна програма наречена „И ние сме креативни“ преку која организираат тематски и креативни работилници кои секој месец се одржуваат во домот (МППС, 2012). 
Во МТ архитектонско снимање беше овозможено само во станбените единици, додека останатите простори беа само разгледани, додека некои од нив беа и фотографски снимени. Пречката при фотографското снимање за останатите простори беше постојаното присуство на станари и негуватели и поради заштита на нивниот личен идентитет.

\section{2 Споредба на резултатите од одговорените прашања од евалуацискиот прашалник EVOLVE}

Резултатите наведени овде го одредуваат степенот на достапност на информациите забележани во домовите и се одредува врз основа на вкупен број на одговорени прашања, бројот на потврдно и негативно одговорени прашања, како и прашањата за коишто нема податок. Споредбата на крајните резултати од евалуацијата на домовите кои програмот EVOLVE ги генерираше е прикажана табеларно во табели групирани според тематски единици. Податоците од табелите потоа се графички сумирани во графикони и се продискутирани за секоја тематска единка одделно.

\section{Станбени единици}

\begin{tabular}{|r|l|l|l|l|l|l|}
\cline { 2 - 7 } \multicolumn{1}{c|}{} & \multicolumn{2}{c|}{ HН } & \multicolumn{2}{c|}{ VC } & \multicolumn{2}{c|}{ M.T. } \\
\hline Одговори & Бр. & $\%$ & Бр. & $\%$ & Бр. & $\%$ \\
\hline Потврдни & 199 & $\mathbf{5 6}$ & 52 & $\mathbf{2 9}$ & 88 & $\mathbf{3 5}$ \\
\hline Негативни & 38 & $\mathbf{1 1}$ & 18 & $\mathbf{1 0}$ & 86 & $\mathbf{3 3}$ \\
\hline Н/П & 117 & $\mathbf{3 3}$ & 110 & $\mathbf{6 1}$ & 83 & $\mathbf{3 2}$ \\
\hline
\end{tabular}

Табела 3 - Споредба на резултатите за станбените единици генерирани од EVOLVE. Извор: авторот. 


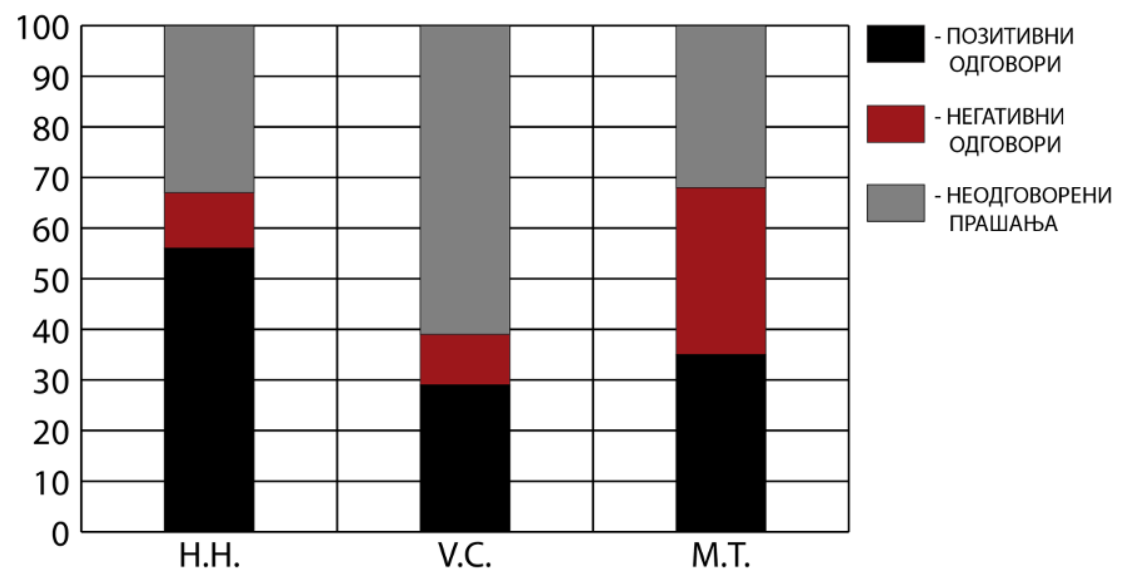

Графикон 1 - Потврден и негативен одговор на прашањата од евалуацијата за станбените единици, изразени во проценти (\%). Извор: авторот.

Од наведените податоци може да се забележи дека домот НН има најмногу потврдни (56\%) и најмалку негативни одговори (11\%) коишто се однесуваат на евалуацијата на станбените единици. Истовремено домот МТ има најмногу негативно одговорени прашања со своите 33\% од вкупните одговорени прашања за домот. При тоа треба да се забележи дека додека беа одговарани прашањата од евалуацијата, за некои од нив доколку беше одбран потврден одговор се отвораше нова нишка на прашања, поради што на пример за домот НН имаше вкупно 354 прашања за станбени единици, за VC имаше вкупно 180 прашања и за МТ вкупно 257 прашања. Малиот број на вкупни прашања за домот VC е резултат на причината што станбената единица е помала од онаа на НН и има помалку содржини од другите домови, особено од домот НН.

\section{Заеднички простор}

\begin{tabular}{|r|l|l|l|l|l|l|}
\cline { 2 - 7 } \multicolumn{1}{c|}{} & \multicolumn{2}{c|}{ НH } & \multicolumn{2}{c|}{ VC } & \multicolumn{2}{c|}{ M.T. } \\
\hline Одговори & Бp. & $\%$ & Бp. & $\%$ & Бр. & $\%$ \\
\hline Потврдни & 186 & $\mathbf{7 2}$ & 36 & $\mathbf{4 7}$ & 31 & $\mathbf{4 1}$ \\
\hline Негативни & 13 & $\mathbf{5}$ & 10 & $\mathbf{1 3}$ & 16 & $\mathbf{2 1}$ \\
\hline Н/П & 61 & $\mathbf{2 3}$ & 31 & $\mathbf{4 0}$ & 28 & $\mathbf{3 7}$ \\
\hline
\end{tabular}

Табела 4 - Споредба на резултатите за заедничките простори генерирани од EVOLVE. Извор: авторот. 


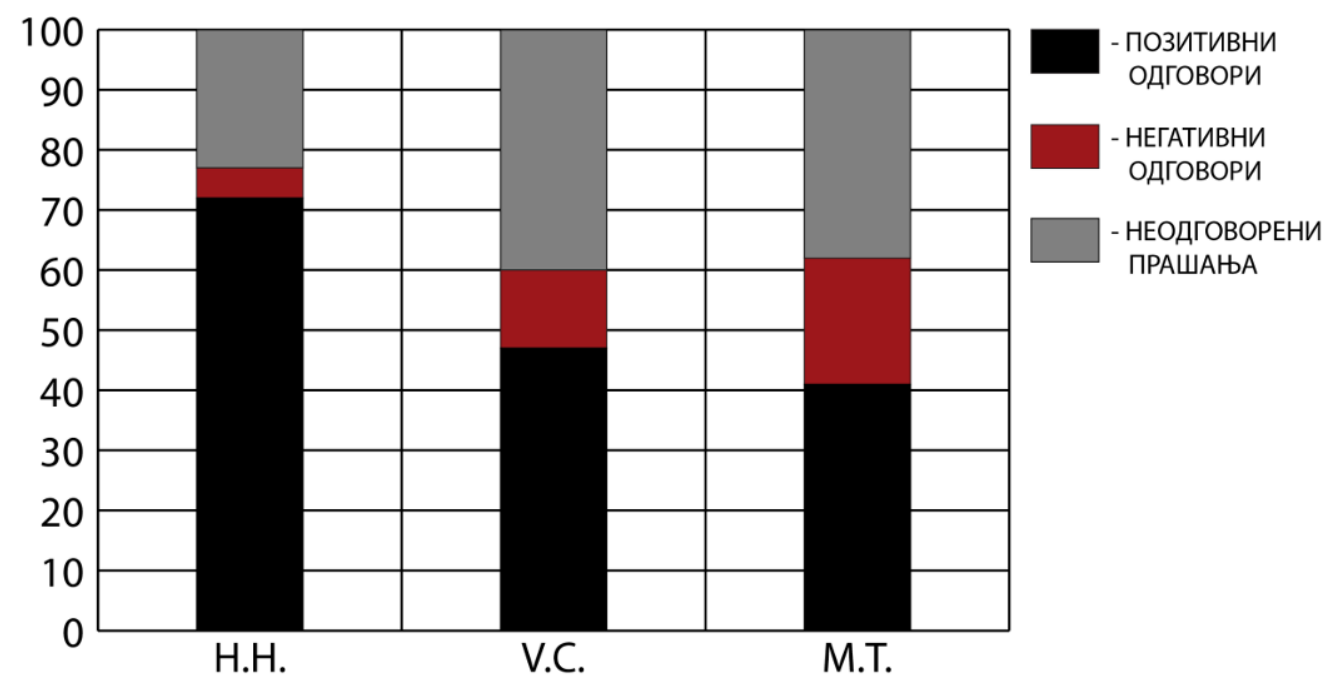

Графикон 2 - Потврден и негативен одговор на прашањата од евалуацијата за заедничките простории, изразени во проценти (\%). Извор: авторот.

Како што може да се забележи од табеларниот и графичкиот приказ на резултатите за заедничките простори генерирани од EVOLVE (Табела 4 и Графикон 2), повторно домот НН фигурира со најголем број на потврдни одговори на прашањата, овој пат со значително помали негативни одговори. Меѓутоа, при снимање на заедничките простори во сите три домови, како што беше претходно објаснето во Методолошки пристап (Поглавје 3), не беа снимени еднаков број на заеднички содржини поради постојаното присуството на голем број на станари во нив. Во домот НН беа снимени поголем број на заеднички содржини во кои беше овозможен неограничен пристап и следствено на тоа бројот на прашања одговорени со „Нема податок“ (Н/П) со своите со 23\% е значително помал од останатите домови.

\section{Циркулација низ просторот}

\begin{tabular}{|r|l|l|l|l|l|l|}
\cline { 2 - 7 } \multicolumn{1}{c|}{} & \multicolumn{2}{c|}{ НH } & \multicolumn{2}{c|}{ VC } & \multicolumn{2}{c|}{ M.T. } \\
\hline Одговори & Бр. & $\%$ & $5 p$. & $\%$ & $5 p$. & $\%$ \\
\hline Потврдни & 31 & $\mathbf{3 4}$ & 26 & $\mathbf{2 9}$ & 10 & $\mathbf{1 2}$ \\
\hline Негативни & 4 & $\mathbf{4}$ & 13 & $\mathbf{1 4}$ & 31 & $\mathbf{3 6}$ \\
\hline Н/П & 55 & $\mathbf{6 1}$ & 51 & $\mathbf{5 7}$ & 45 & $\mathbf{5 2}$ \\
\hline
\end{tabular}

Табела 5 - Споредба на резултатите за циркулацијата низ просторот генерирани од EVOLVE. Извор: авторот. 


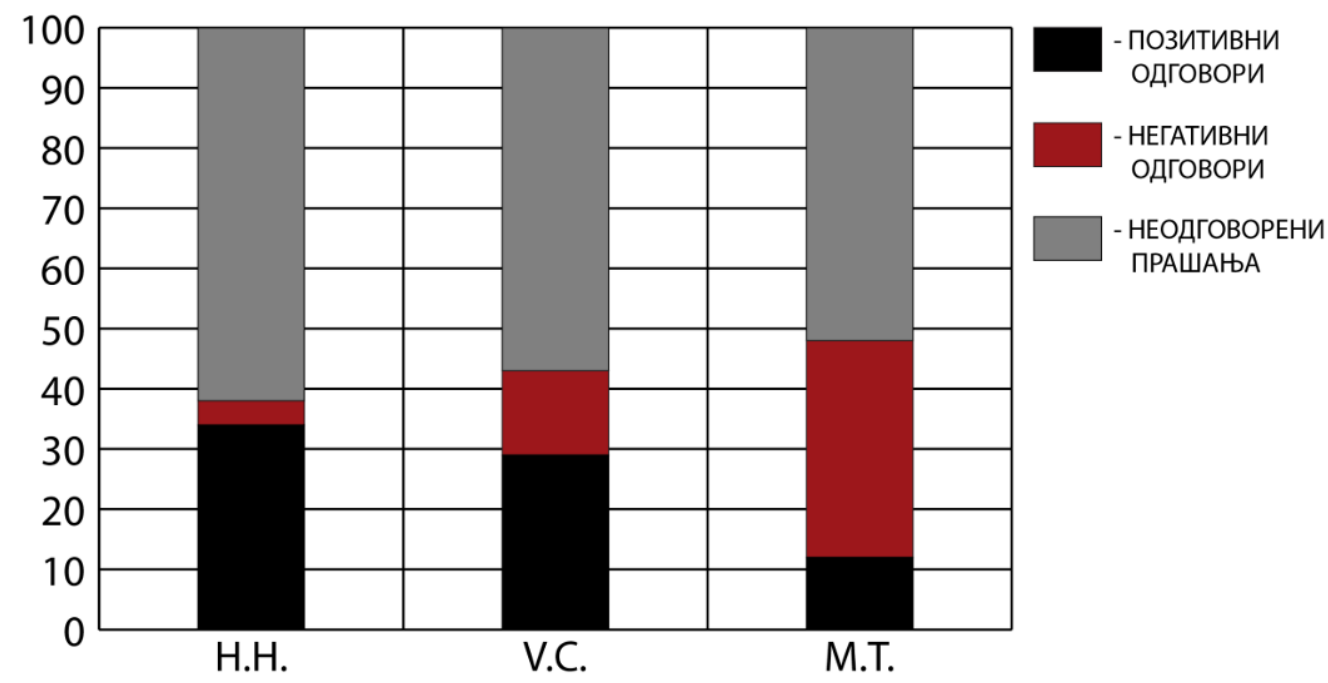

Графикон 3 - Потврден и негативен одговор на прашањата од евалуацијата за циркулација низ просторот, изразени во проценти (\%).Извор: авторот.

Кај циркулацијата низ просторот или поточно ходниците во домовите беше забележана драстична разлика во формата и должината на ходникот во секој дом поединечно, а сепак бројот на прашањата одговорени за домовите беа еднакви помеѓу себе. Домот МТ повторно има најмалку потврдно одговорени прашања, но овој пат и процентуално најмногу негативно одговорени прашања (36\%). Ова делумно се должи на причината што ходникот во МТ е пократок од другите, нема завои и дополнителни содржини, туку претставува едноставно премин од една просторија во друга.

Заклучок: Целта на оваа анализа е да ги спореди резултатите добиени од евалуацијата, како и да се прегледа начинот на којшто се одговорени прашањата за секој дом, а не да изврши рангирање на домовите во однос на спроведената евалуација. Резултатите кои произлегоа од евалуацискиот прашалник EVOLVE вршат споредба со тоа што овозможуваат преглед на посилните и послабите страни на секој од домовите што би помогнало во препознавање на евентуална можност за подобрување. Причината што домот НН доминира со своите потврдно одговорени прашања во сите три параметри го оправдува обидот позитивно оценетите карактеристики на домот да се извлечат како поуки и прелиминарни податоци за изработка на сугестии за модификација на домот со најмногу негативно одговорени прашања, а тоа е домот МТ. Исто така, бидејќи домот НН има процентуално повеќе одговорени прашања од евалуацискиот прашалник се очекува дека анализата на тие резултати во Поглавје 5 ќе опфаќаат поголем дел од дискусијата. Во 
Поглавје 5 , ќе бидат детално наведени и анализирани карактерните особини на секоја од евалуираните параметри кај секој дом поединечно, но и споредбено, сѐ со цел да се извлечат поуки за изработка на сугестии за уредување на ентериер за лица со АБ. 


\section{5. АНАЛИЗА НА РЕЗУЛТАТИТЕ}

Во ова поглавје ќе бидат детално анализирани поголемите наоди од евалуацискиот прашалник EVOLVE и ќе бидат споредени или поткрепени со податоци од соодветна литература. Наодите всушност се претставени како сугестии, тематски подредени за поголема прегледност. Најпрво ќе бидат разгледани општи сугестии кои се однесуваат за сите простории, а потоа истите ќе бидат по потреба надополнети во секоја тематска единка соодветно.

\section{1 Општи поуки заеднички за сите простории}

Додека беа разгледувани поуките извлечени од евалуацијата беа забележани заеднички особини кои се повторуваа во секоја тематска единка. За поголема прегледност на овие препораки најдобро е да бидат разгледани заедно и тоа пред тематските единки, со цел да бидат објаснети поопшто пред да се разгледуваат детално за секој дом поединечно.

Штекерите да бидат на височина од 450 до 1200мм од подот.

Прекинувачите за светло да бидат на височина од 1000 до 1200мм од подот.

Просторијата да биде декорирана во светли бои и без сјајни површини.

Осветлувањето да биде подеднакво распространето и да нема места со длабоки сенки.

Кваките на вратите да бидат лесни за употреба.

Прагот на вратата да биде порамнет со подот.

Да има присуство на природна светлина.

Табела 6 - Општи препораки заеднички за сите простори. Извор: авторот. 
Според Tofle et al. (2004) и Brawley (2006) влијанието на боите во просторот наменет за нега cè уште не е докажано. Tofle et al. (2004) предупредуваат дека одлуката за употребата на конкретна боја во здравствените објекти е преземена од одредени водичи коишто се изработени според мислења што не се потпираат на проверени факти туку на „псевдонаучни тврдеља“ (Tofle et al., 2004, p.4). Според нивната понатамошна дискусија на темата, како и од препораката на Utton (2009), може да се заклучи дека применета на контраст во просторот е поважна отколку примената на конкретни бои. Кога некој елемент или предмет во просторот треба да се истакне по значајност најдобро е тој да содржи боја која ќе биде контрастна на бојата што го опкружува. При тоа, треба да се внимава на едно поинакво делување на контрастот. Marquardt (2011) предупредува дека контрастот во подот забележан при преминот од еден материјали во друг, разликата во боењето на подот или присуството на темни шари во дизајнот на подната облога може да создаде илузија кај лицата со деменција за присуство на отвори во подот.

Истражувањата од видот на студијата на Alverann (1979) само набројуваат колку пати конкретна боја е одбрана како прв избор на старите лица во домовите што не може да се употреби како водич за избор на боја, особено ако се земе предвид образложувањето на Brawley (2006) дека реакциите предизвикани од конкретна боја потекнуваат од личното искуство на човекот поврзано со бојата или од асоцијации наметнати од културната средина. Одовде може да се заклучи дека изборот на конкретна боја може да се сведе на веројатноста за допадливост. Fleming et al.,(2003) препорачува сите елементи од просторот кои се наменети за употреба од станарот (врата, стол, држач за раце и сл.) задолжително да имаат контрастна боја со бојата на позадината. Спротивното на ова важи за елементите од ентериерот кои не се наменети за станарите, односно тие да бидат обоени во боја еднаква со бојата на позадината.

Не може да се говори за бојата во ентериерот без да се надоврзе со осветлувањето во просторот. Burke (in Hodges, Bridge \& Chaudhary, 2006) инсистира на тоа дека контрастот на боите е успешен само во соодветно осветлен простор. По разгледувањето на старосните промени во човековиот вид претходно споменати во поглавјето Општи карактеристики на 
АБ, станува јасна потребата за преземање мерки коишто ќе ги контролираат карактеристиките на светлината во просторот. Brawley (2005) изнесува дека добрата светлина ги подобрува квалитетот на бојата, текстурата и формата. Оттука, светлината помага во подобро разбирање на средината во која живееме. Осветлувањето во просторот може да биде природно и вештачко, но и двата вида се подеднакво важни и со помошта на архитектонски елементи и друг вид помагала можат да се контролираат во полза на човекот. Присутноста на максимално природно осветлување, а со тоа и присуството на прозорци во домот, има еден значаен и често повторуван аспект според кој, прозорецот ги поврзува станарите со надворешниот свет и ги одржува во контакт со временските услови, сезоната и времето од денот (Sloane et al., 2005; Sifton in Hoof and Kort, 2009).

При изборот на светлоносните тела треба да се внимава на изгледот, бидејќи целта е да се создаде ентериер со домашна атмосфера. Употребата на светлосен извор со институционален изглед може да има негативен ефект врз атмосферата на просторот. Regnier (2002) истакнува дека употребата на еднолично и нерамномерно осветлување е типична особина на објектите од здравството што ги прави многу здодевни. Тој препорачува да се употребува мешавина од различни извори на светлина: „природна светлина; вградени флуоресцентни и ламби со вжарено влакно; зидни, подни и столни ламби; плафонски светла и индиректни вградени светла во ниша на плафонот (Regnier, 2002, р.73). Комбинацијата на различни видови на светлински извор не само што помага на лицата со пречки во видот, туку и како што вели Regnier (2002, p.73) „ги оживува мидовите, теписоните и мебелот“.

\section{ПРИСТАПНОСТ И БЕЗБЕДНОСТ}

Како што претходно беше образложено во Карактеристики на АБ, старите лица со АБ се здобиваат со одредени когнитивни и физички нарушувања во текот на болеста кои го попречуваат слободното и безгрижно движење низ просторот. Најчести причини за паѓања набројани од страна на Hanson (2001, р.4-5) се „лизгањето, препнување на слабо одржувани подни облоги, или препнување на предмети“. 
Во секоја тематска единица во која се поделени препораките се споменуваат соодветни мерки за заштита на станарот од паѓање. Тоа го прави спречувањето на можноста за паѓање најголема грижа на дизајнерите при уредување на простор за стари лица со пречки во помнењето. Како релевантни фактори споменати во категоризацијата на Connel \& Wolf (in Joseph, 2010) кои се поврзани со внатрешниот простор и е веројатно да предизвикаат паѓање кај станарите со АБ може да се издвојат следните: движење низ мрачен простор; физички пречки во просторот кои можат да го сопнат станарот, како на пример повисок праг; неправилен избор на подна облога која го попречува лесното движење.

Застрашувачкиот аспект на паѓањето е објаснет со статистиката на Centre for Disease Control and Prevention (in Rose, 2011) според која кога лицата над 65 годишна возраст ќе паднат тоа најчесто предизвикува „умерени до сериозни повреди, како фрактура или траума на главата и може да го зголеми ризикот за предвремена смрт“. Според Buzink et al. „25-50\% од паѓањата на старите лица резултираат во некаков вид на физичка повреда“ (Buzink et al., 2005, p.16) и сериозноста на проблемот само се засилува со тоа што откако ќе се случи првото паѓање постои огромна веројатност дека ќе следи и повторно паѓање (Salva et al., 2011). Оттука може да заклучи дека паѓањето, како честа и сериозна појава кај старите лица со АБ, е една од главните безбедносни мерки во уредување на ентериерот.

Според Brawley (1997,) целата подна површина треба да биде израмнета и, како што предупредува Weinhold (in Brawley, 1997, p.238), да не се употребуваат прагови низ просторот бидејќи го попречуваат движењето на старите лица. Оваа препорака иако е наведена во оваа тематска единица се однесува воопшто на целиот простор по кој станарите се движат. Прагот на премините во просториите не само што предизвикува сопнување за станарите со пречки во видот, туку пречи и на слободното поминување на лицата кои имаат потреба од инвалидска количка или друг вид на помагало за мобилност. 


\section{Предлози извлечени од прегледаната литература на темата}

\begin{tabular}{|c|}
\hline Опши препораки \\
\hline $\begin{array}{l}\text { Да се употребува мешавина од различни извори на светлина: природна светлина; вградени } \\
\text { флуоресцентни и ламби со вжарено влакно; зидни, подни и столни ламби; плафонски } \\
\text { светла и индиректни вградени светла во ниша на плафонот (Regnier, 2002). }\end{array}$ \\
\hline $\begin{array}{l}\text { Просторот да има „светли sидови кои ќе ја рефлектираат светлината“ (Regnier, 2002, } \\
\text { р.73) но нема да создаваат одблесок. }\end{array}$ \\
\hline $\begin{array}{l}\text { Да нема разлика во боењето на подот или присуство на темни шари во дизајнот на подната } \\
\text { облога, бидејќи може да создаде илузија кај лицата со деменција за присуство на отвори } \\
\text { во подот. (Marquardt, 2011) }\end{array}$ \\
\hline $\begin{array}{l}\text { Да не се употребуваат посветли тонови од темните бои наспроти потемни тонови од } \\
\text { светлите бои при создавање на контраст за лица со АБ. (Brawley in Tofle et al., 2004) }\end{array}$ \\
\hline
\end{tabular}

Табела 7 - Предлози за тоалетот извлечени од прегледаната литература. Извор: авторот. 


\section{2 Станбена единица}

\subsection{1 Влез во станбените единици}

\begin{tabular}{|c|c|c|c|c|}
\hline & Препораки за влезот во станбената единиц̧а & H. H. & V.C. & M. T. \\
\hline 1 & $\begin{array}{l}\text { Влезот во станбените единици е повлечен навнатре од } \\
\text { главната линија на движење во ходникот, овозможувајќ } \\
\text { просторот околу влезот да содржи декорации и лични } \\
\text { предмети на станарот кои што ќе создадат препознатлива } \\
\text { атмосфера за станарот. }\end{array}$ & $\checkmark$ & $\mathrm{x}$ & $\mathrm{x}$ \\
\hline 2 & $\begin{array}{l}\text { Просторот околу влезот да биде препознатлив за станарот } \\
\text { преку изложување на лични предмети како на пример: } \\
\text { предмети од детството, фотографии од семејството или од } \\
\text { станарот, или други препознатливи фигури. }\end{array}$ & $\sqrt{ }$ & $\mathrm{x}$ & $\mathrm{x}$ \\
\hline 3 & Ознаките на вратите или до вратите да бидат испакнати. & $\checkmark$ & $\mathrm{x}$ & $\mathrm{x}$ \\
\hline 4 & $\begin{array}{l}\text { Влезната врата да биде во боја контрастна на sидот кој ја } \\
\text { опколува. }\end{array}$ & $\checkmark$ & $\checkmark$ & $\checkmark$ \\
\hline 5 & $\begin{array}{l}\text { Влезната врата да нема одблесок (да бидат употребени матна } \\
\text { боја и матен премаз). }\end{array}$ & $\checkmark$ & $\checkmark$ & $\mathrm{x}$ \\
\hline 6 & Кваките на вратите да бидат лесни за употреба. & $\checkmark$ & $\checkmark$ & $\sqrt{ }$ \\
\hline 7 & Прагот на вратата да биде порамнет со подот. & $\checkmark$ & $\checkmark$ & $\checkmark$ \\
\hline 8 & $\begin{array}{l}\text { Влезовите да бидат осветлени преку ден и ноќ со светилки кои } \\
\text { ја насочуваат светлината надолу (downlight) и прикриен } \\
\text { светлосен извор. }\end{array}$ & $\checkmark$ & $\mathrm{x}$ & $\mathrm{x}$ \\
\hline 9 & Осветлувањето на влезот да биде над 300 luxa. & $\checkmark$ & $\mathrm{x}$ & $\mathrm{x}$ \\
\hline 10 & $\begin{array}{l}\text { Да нема присуство на чергичиња пред и зад влезот (можат да } \\
\text { предизвикаат пречки во движењето). }\end{array}$ & $\checkmark$ & $\checkmark$ & $\checkmark$ \\
\hline
\end{tabular}

Табела 8 - Препораки за влезот во станбената единица. Извор: авторот.

\section{ОРИЕНТАЦИЈА}

За време на посетата на домовите за долготрајна нега впечатливо и заедничко за сите домови беше присуството на релативно долг ходник, со станбени единици распоредени надолж двете страни на ходникот и влез во станбените единици кој се сочинеше од врати со идентичен изглед. Во средина со ваква карактеристична одлика потешко би се ориентирала дури и индивидуа без пречки во помнењето. Единственото диференцирање на влезовите во станбените единици воедно и заедничко за трите домови беше 
присуството на ознаки со реден број на станбените единици. Покрај овој вид означување во НН на секоја влезна врата беа забележани и ознаки со името на станарот кој е сместен во станбената единица, поставени на зидот непосредно до вратата (Слика 13).

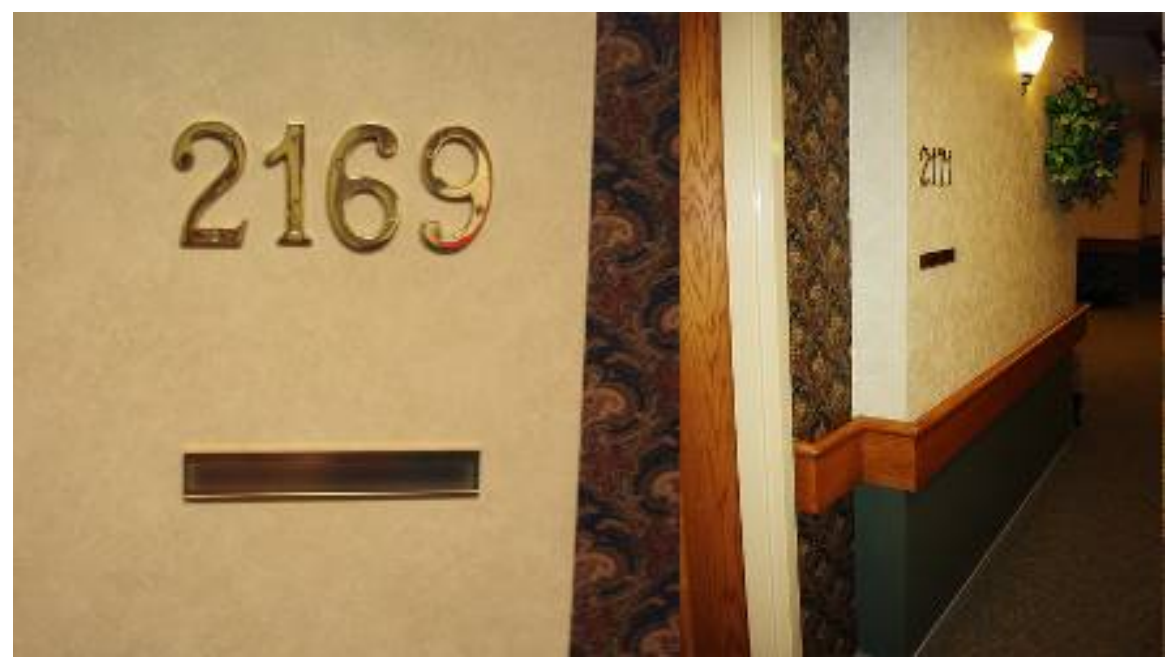

Слика 13 - Ознаки со бројот на станбената единица и името на станарот којшто е сместен во единицата. Извор: авторот.

Означувањето на влезовите на станбените единици со реден број или со име очигледно е наменето за членовите од персоналот или посетителите во домот, бидејќи во домот престојуваат стари лица со АБ кои имаат пречки во помнењето и видот и се претпоставува дека нема да го запомнат бројот на својата станбена единица или нема да го забележат натписот со своето име. Brawley (1997) објаснува дека лицата со АБ во вториот и третиот стадиум имаат потешкотии со ознаки кои треба да бидат прочитани или разбрани, поради што таа препорачува да се употребуваат ознаки со едноставна графика. Бидејќи, како што истакнуваат Hodges, Bridge и Chaudhary (2006) лицата со деменција најчесто гледаат надолу при движењето низ просторот, тогаш можеби станарите подобро би го забележале натписот со своето име доколку поставувањето на ознаките е „на височина на наведнат поглед на станарите“ (Marquardt, 2011, p.30). Меѓутоа сепак, ориентацијата во просторот и препознавањето на сопствената станбена единица за лицата во подоцнежните стадиуми на АБ ќе биде поуспешно доколку се употреби и дополнително означување кое ќе биде наменето лично за станарот.

Една од уникатните особини на домот НН беше присуството на лични предмети и фотографии на влезот (слика 14), кои му припаѓаат на лицето што престојува во 
станбената единица. Овие лични предмети обично беа прикачени на влезната врата од станбената единица или понекогаш и на зидот до неа. Како дополнение на тоа, во НН влезот во станбените единици беше повлечен навнатре (за околу $30 \mathrm{~cm}$ ) и пред секој влез се создаваше простор во којшто може да се постават личните предмети при што не би пречеле во слободното движење низ ходникот. Присуството на лични предмети на влезот има значајна улога во препознавањето на станбената единица од страна на станарот. Овој вид на означување се препорачува во многубројни истражувања (Brawley, 1997; Calkins \& Marsden, 2001; Marquardt, 2011; ). Nolan et al. (in Marquardt, 2011) ја посочуваат како успешна примената на различни видови на ознаки на влезот како на пример, истакнување на лични предмети, ознаки со име и портрет и фотографија од младоста на станарот.

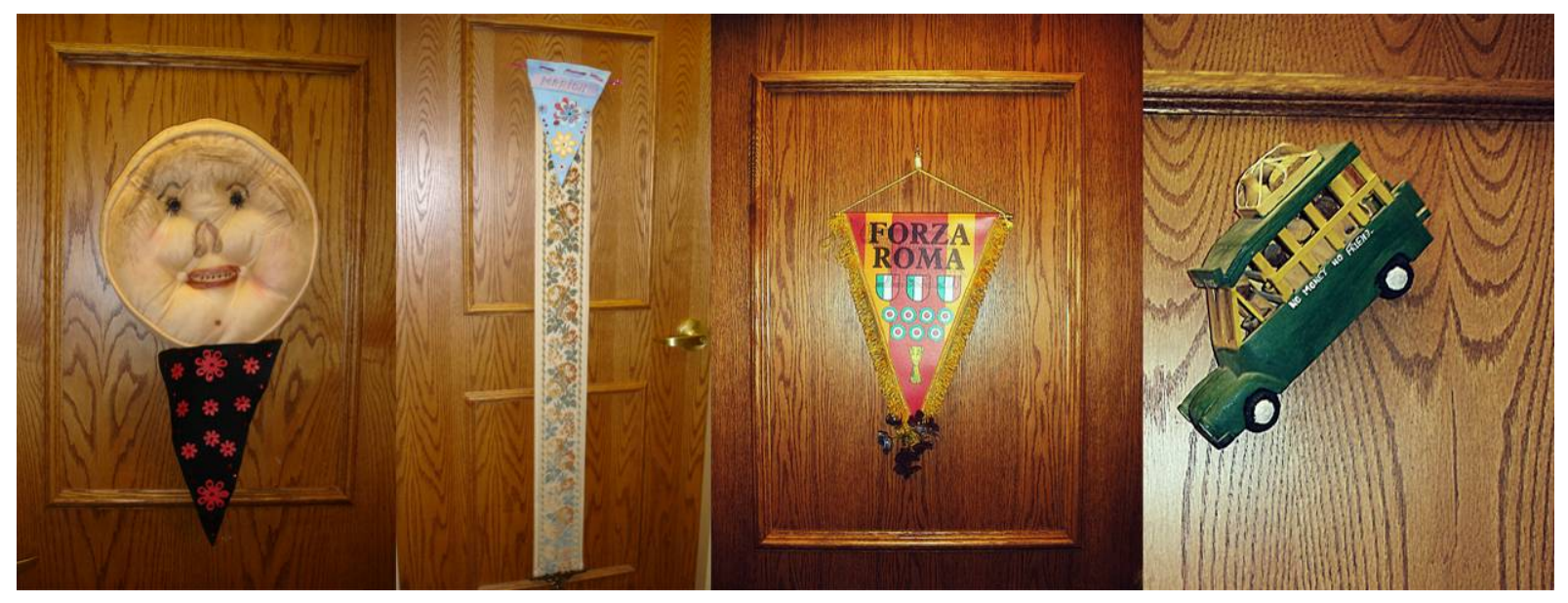

Слика 14 - Лични предмети на станарот закачени на влезната врата од станбената единица. Извор: авторот.

Според менаџерот на домот НН личните предмети кои ќе бидат изложени на влезот најчесто се одбирани од страна на членовите од семејството на станарот или од самиот станар (Walker, 2011). Тоа овозможува да се одбере предмет кој ќе има некаква интимна значајност за станарот и ќе помогне во лесно препознавање на предметот и, следствено на тоа, полесно препознавање на својот влез во станбената единица. Вредноста на поставувањето на лични предмети на влезот во станбените единици Zeisel (2005) ја надополнува со можноста на поминувачите да дознаат нешто повеќе за станарот и да го третираат како личност со минато наместо само како „пациент“. Начинот на изложување на личните предмети може да биде во витрина поставена на sидот до вратата - често 
нарекувана „memory box“ (Utton, 2009, p.387) или „shadow box“ (Regnier \& Denton, 2009, р.180), или закачени на самата врата, по примерот на НН (слика 14).

Покрај означувањето во НН, во ниту еден од останатите два домови немаше означување на влезовите поинакво од знаци со реден број на станбените единици. Влезовите изгледаа идентично помеѓу себе и немаа никаков особен белег по кој би се разликувале. Оваа одлика може да се препознае како можност за подобрување со цел да се овозможи полесно ориентирање на станарите, па и на вработените низ просторот.

ОСВЕТЛУВАНЕ И БОЈА

Означувањето на влезовите, покрај поставувањето на лични предмети, може да се реши со боење на рамката на вратата во боја контрастна на зидот, по примерот забележан во реновирањето на два Шведски домови опишано од Falk, Wijk и Persson (2009). Доколку истиот начин се применува за сите влезни врати, како и за сите отвори кои се наменети за влегување на станарите, ќе се создаде еден вид на унифицирано и суптилно означување на влез кое ќе биде едноставно да се следи и препознае од страна на станарите.

Покрај главното неонско осветлување во ходниците, над секоја влезна врата во домот НН имаше поставено неонско осветлување насочено надолу кон вратата и по една мидна ламба помеѓу секои две станбени единици (слика 15). Аидната ламба заедно со тапетите поставени во пределот каде што се наоѓаат двата влеза симболично го означуваат постоењето на станбени единици на тоа место и создаваат домашна и топла атмосфера. На ниту едно место во ходникот не беше забележан потемен или засенчен дел бидејќи осветлувањето беше рамномерно распределено по целата должина на ходникот. Дополнително на тоа, контрастот помеѓу sидовите и вратите на станбените единици во НH, согласно со препораката на Falk, Wijk и Persson (2009), беше постигнат преку боење на рамката на вратата во боја контрастна со бојата на вратата и воедно со бојата на околните sидови. 


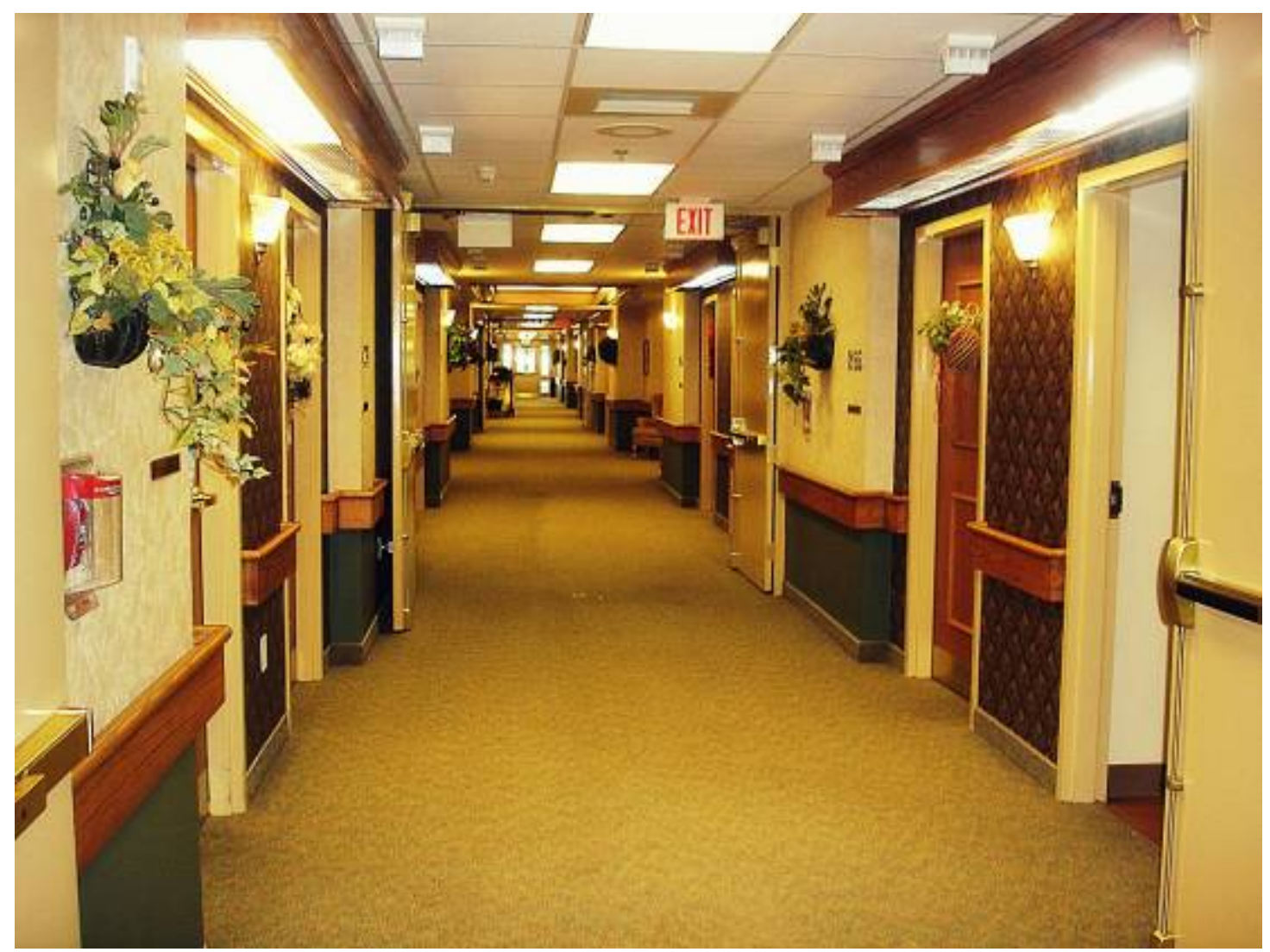

Слика 15 - Рамномерно распределено осветлување во ходникот на домот НН и начин на осветлување на влезовите во станбените единици. Извор: авторот.

Слично на НН и во домот VC покрај главното неонско линеарно осветлување имаше sидни ламби до влезовите на станбените единици (слика 16). Единствената непријатна карактеристика на овие sидни ламби беше тоа што светеа со јарка бела светлина поставена близу до погледот, особено и затоа што се наоѓa во простор каде одблесокот претставува сериозен проблем. 


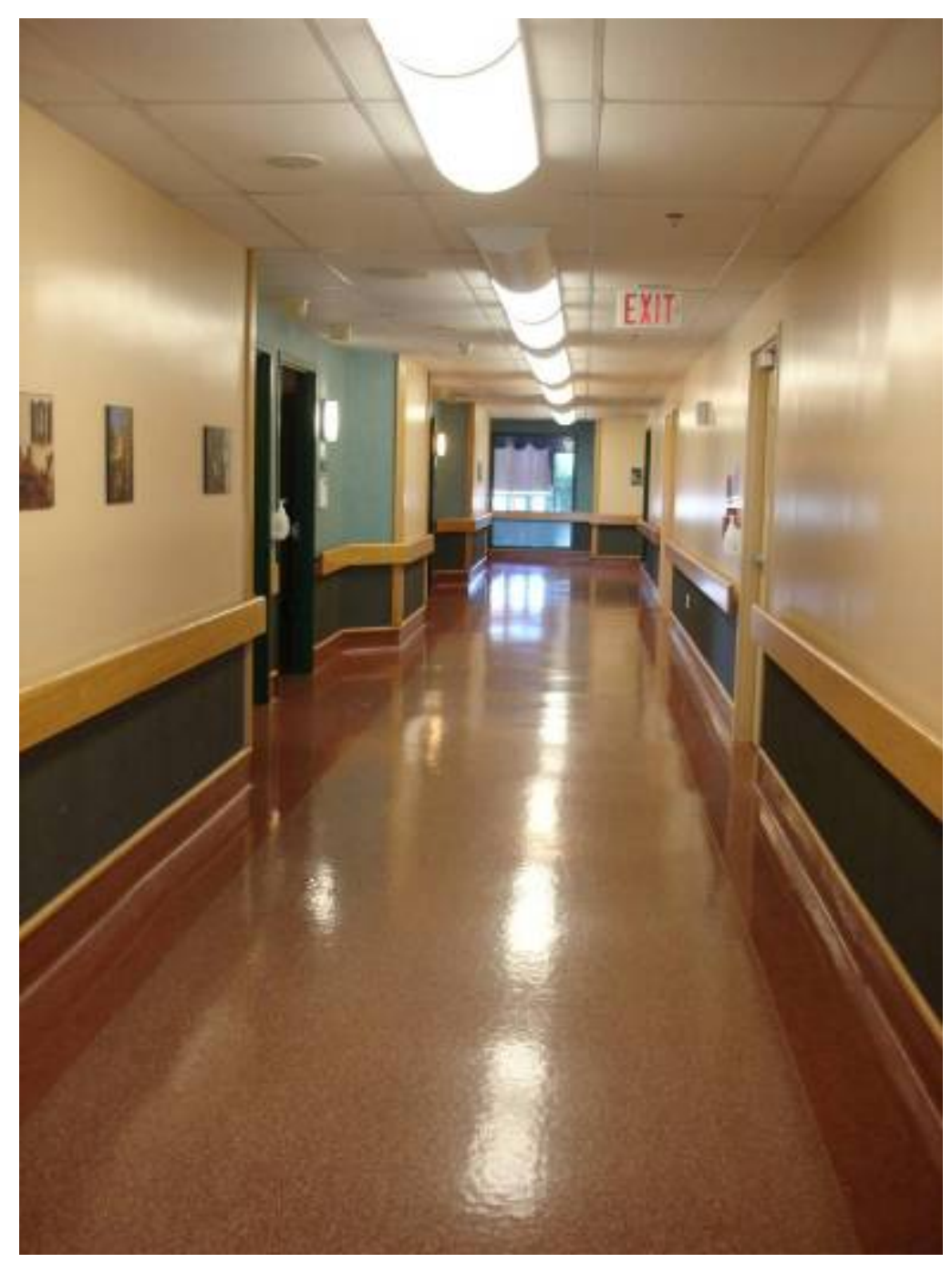

Слика 16 - Осветлувањето во ходникот и до влезовите на станбените единици во домот VC. Извор: авторот.

Во домот МТ покрај главното неонско светло, немаше дополнително осветлување на влезовите. Што се однесува до препораката според која вратите треба да бидат во контрастна боја, влезните врати во домот МТ очигледно се разликуваа од зидовите поради белата боја на sидовите. Меѓутоа, на вратите во домот МТ беше забележано присуство на одблесок кој и не беше толку впечатлив во моментот на снимањето на просторот поради слабото осветлување во ходникот. Иако звучи како две негативни карактеристики да си помагаат една со друга, сепак треба да следат модификации, бидејќи услови на слабо осветлување во простор како ходник, кој е често употребуван од станарите не само што не е пожелно туку може да доведе и до незгоди. 


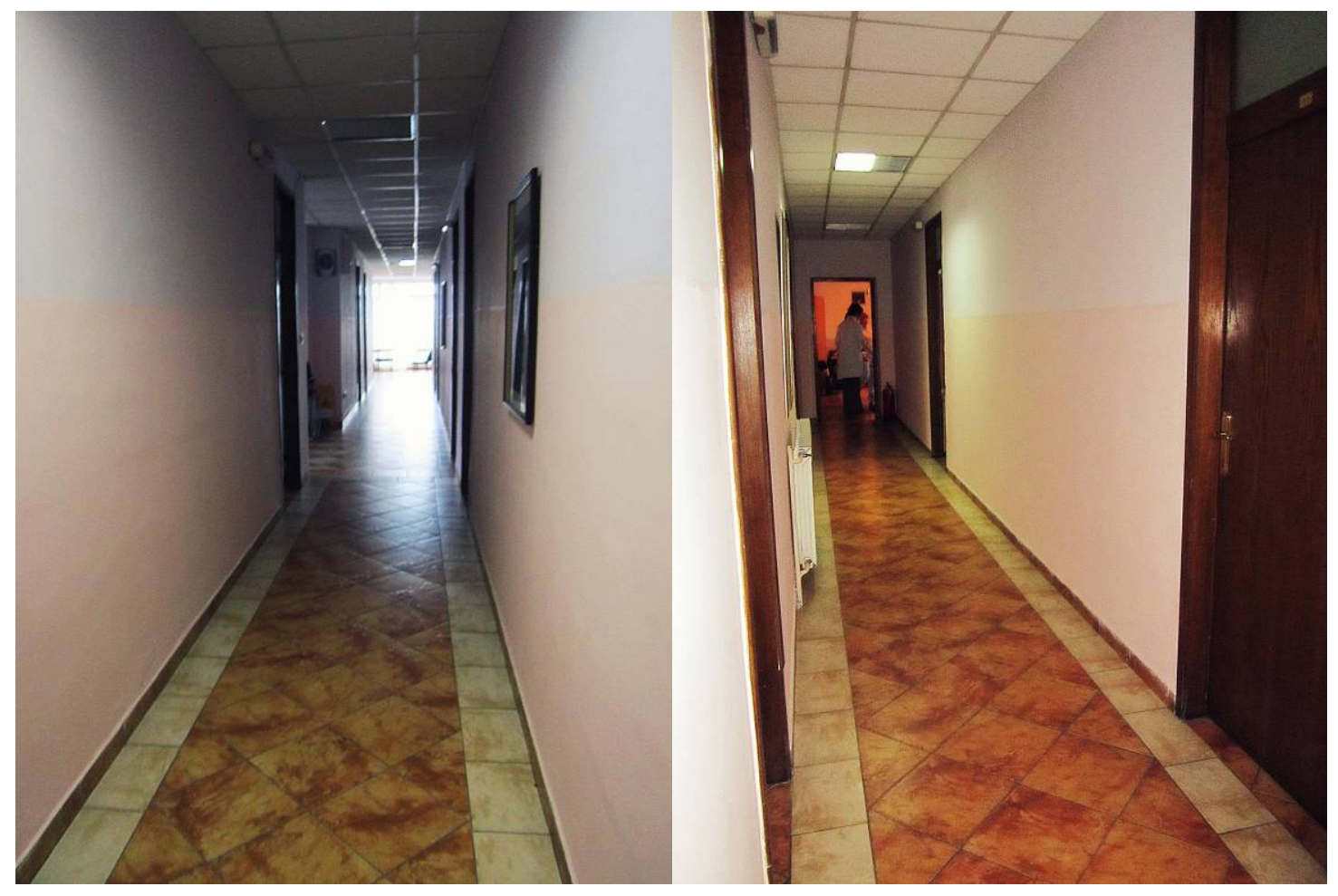

Слика 17 - Осветлувањето во ходникот во домот МТ. Извор: авторот.

Во трите домови начинот на отворање на влезните врати на станбените единици, како и вратите на други простории предодредени за употреба од станарите, беше еднаков и се состоеше од еднокрилна врата со отворање навнатре и со еднорачна квака лесна за управување. По примерот на боење на вратите во боја еднаква со бојата на околните sидови во случај кога влегувањето не е наменето за станарите, може да се заклучи дека доколку некоја врата не е наменета за употреба од станарите тогаш може да се примени начин на отворање кој е непознат за станарите со поинаква квака.

Бидејќи тематската единица се однесува на влезови во станбените единици кои се распоредени во ходникот или ходниците на домот за нега, препораката, Да нема присуство на чергичиња пред и зад влезот“ можеби не е толку неопходна во овој случај затоа што при влегувањето од ходник во станбена единица нема потреба од чергиче. Оваа препорака може во случајот да се однесува за премините кон тераса, трем, двор и сл., 
меѓутоа може да се однесува за било каква употреба на чергичиња во просторот. Сепак, влегувањето во станбените единици во сите снимени домови не беше физички попречено со присуството на чергичиња пред или зад влезот или со постоењето на праг на влезот. Со тоа беше овозможен непречен пристап за лица со помагала во движењето.

\section{Предлози извлечени од прегледаната литература на темата}

\section{$\underline{\text { Влез }}$}

Лицата со АБ во вториот и третиот стадиум имаат потешкотии со ознаки кои треба да бидат прочитани или разбрани, поради што се препорачува употребата на ознаки со едноставна графика. (Brawley, 1997)

Сите натписи и ознаки наменети за станарите да бидат поставени на „височина на наведнат поглед на стари лица“. (Marquardt, 2011, p.30)

Табела 9 - Предлози за влезот во станбените единици извлечени од прегледаната литература. Извор: авторот.

\subsection{2 Претсобје во станбената единица}

\begin{tabular}{|c|l|c|c|c|}
\hline & Препораки за ходникот на станбената единица & H. Н. & V. C. & М. T. \\
\hline 1 & Во претсобјето да има општ складишен простор. & $\checkmark$ & X & $\checkmark$ \\
\hline 2 & $\begin{array}{l}\text { Доколку плакарот е поставен во претсобјето на станбените } \\
\text { единици, тогаш тој да биде вграден и да не претставува пречка } \\
\text { во просторот. }\end{array}$ & $\checkmark$ & х & х \\
\hline 3 & Sидовите во претсобјето да имаат светла боја. & $\checkmark$ & $\checkmark$ & $\checkmark$ \\
\hline 4 & Штекерите да бидат на височина од 450 до 1200мм од подот. & $\checkmark$ & Н/П & х \\
\hline 5 & $\begin{array}{l}\text { Прекинувачите за светло да бидат на височина од 1000 до } \\
\text { 1200мм од подот. }\end{array}$ & $\checkmark$ & Н/П & $\checkmark$ \\
\hline
\end{tabular}

Табела 10 - Препораки за претсобјето во станбената единица. Извор: авторот.

Бидејќи се работи за еднособени станбени единици не е невообичаено гардероберот на станарот да се наоѓа во претсобјето со цел да не претставува пречка при движењето низ станбената единица. Така беше случајот во МТ и НH, но не и во VC каде што гардероберот беше поставен во просторот за спиење. Според водичот на Ministry of Health 
and Long-Term Care за уредување на домови со долготрајна нега (2009) гардероберот во станбените единици треба да има минимална складишна површина од $0.56 \mathrm{~m}^{2}$ за употреба од едно лице. Во домот МТ гардероберот (Слика 18) беше наменет за едновремена употреба од двајца станари, не беше вграден туку самостојно стоеше зад влезната врата и беше помал од препорачаната складишна површина од Ministry of Health and Long-Term Care.
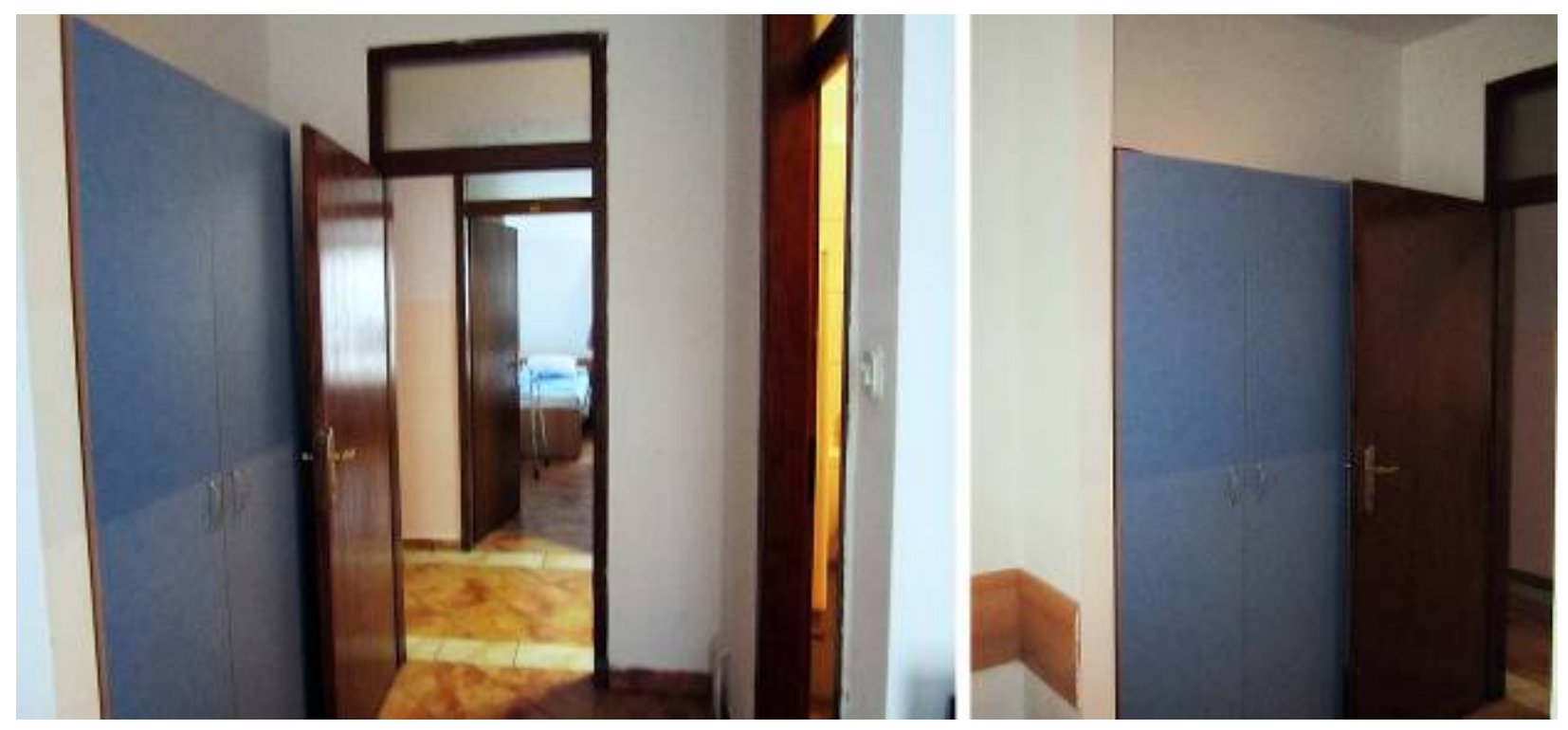

Слика 18 - Претсобјето во домот МТ. Извор: авторот.

Во домот VC иако гардероберот беше наменет за употреба од еден станар (слика 19) тој сепак беше помал од $0.56 \mathrm{~m}^{2}$, меѓутоа станбената единица е доволно пространа да може да се смести дополнителен складишен простор од типот на комода со фиоки. 


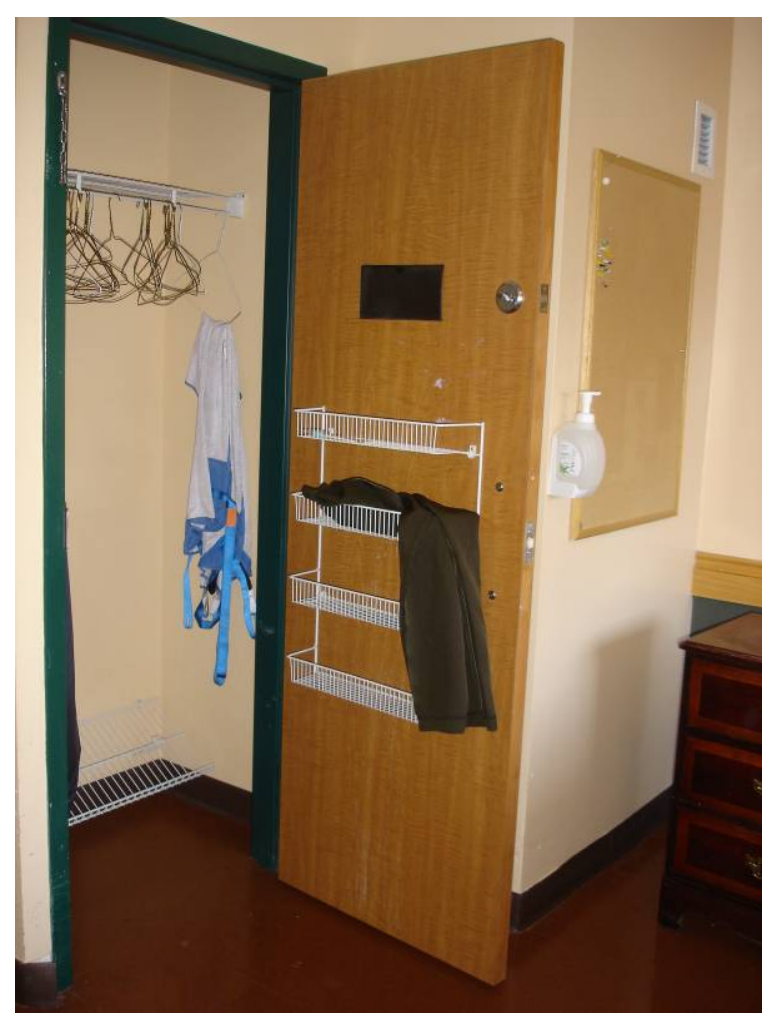

Слика 19 - Гардероберот во домот VC кој што се наоѓa во спалниот простор. Извор: авторот.

Како што може да се забележи од фотографијата (Слика 20) гардероберот во НН е вграден и е значително поголем од останатите снимени примери. Дополнителна заштеда на простор и елиминирање на физички пречки во претсобјето претставуваат лизгачките врати на гардероберот. Спротивно на тоа се вратите од гардероберот во МТ каде што кога се отворени претставуваат пречка на влезот во станбената единица.

Hoof, Kort, Van Waarde и Bloom (2010) истакнуваат дека лицата со деменција имаат потешкотии при изборот на облека од гардероберот и како потенцијално решение за тоа ја елаборираат препораката на Namazi и DiNatale Johnson (in Hoof, Kort, Van Waarde and Bloom, 2010) за овозможување на независност на станарот при самостојно облекување со тоа што ќе се отстрани присуството на алтернативна облека во гардероберот од која станарот треба да избере што да облече и да направи комбинација. Namazi и DiNatale Johnson (1992, abstract) како начин за отстранување на широк избор на облека предлагаат 


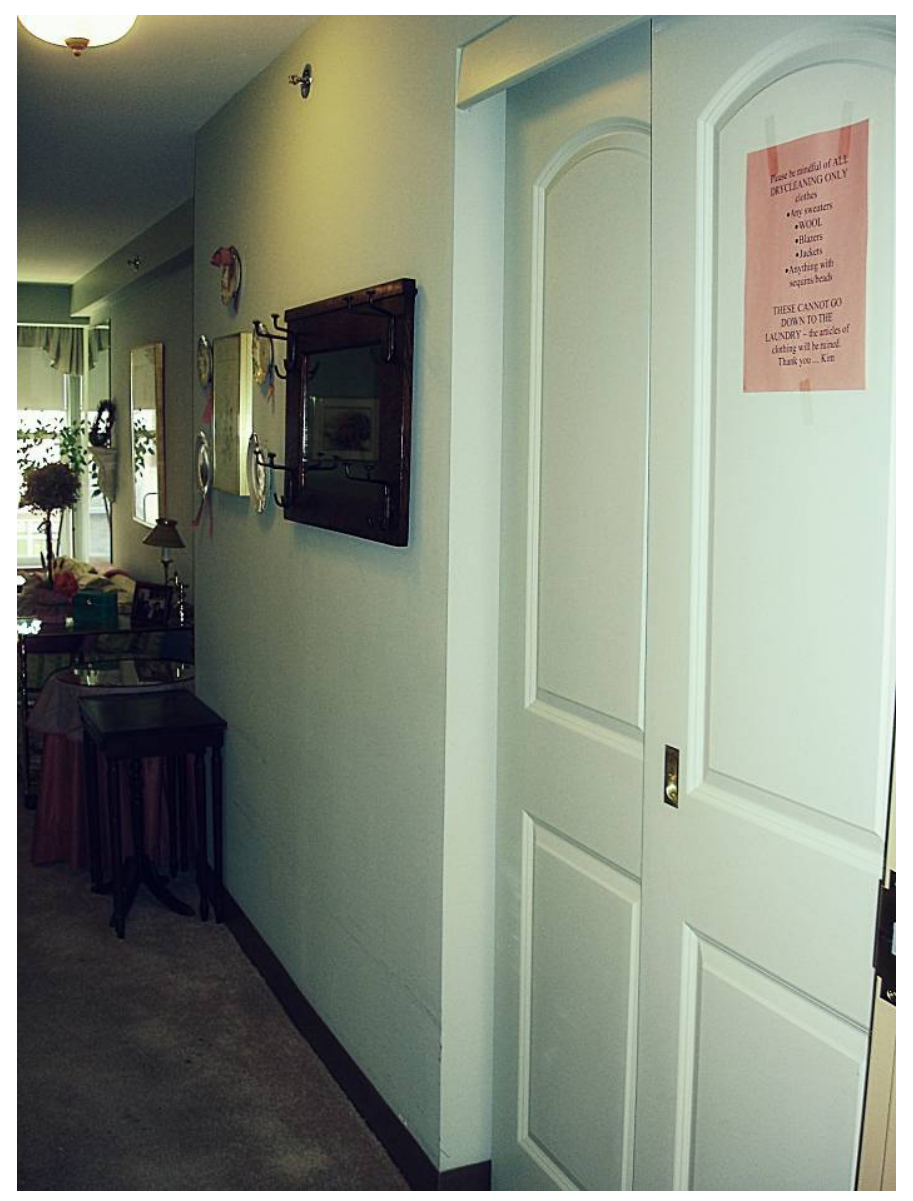

Слика 20 - Гардероберот во претсобјето на станбените единици во НН. Извор: авторот.

гардеробер кој е поделен на два дела од кои едниот ќе биде заклучен и во него ќе биде сместена облеката од која членови од персоналот или семејството на станарот ќе сортираат комбинации и ќе ги наредат во другиот дел на гардероберот кој што ќе го користи станарот. Препораката не може да се смета како конечно решение за проблемот на избор на облека поради малиот број на испитаници вклучени во студијата (осуммина), меѓутоа сепак е корисен совет за обид за кој што е потребно само посветеност на персоналот. Овој начин би можел да се примени во домовите МТ и $\mathrm{HH}$, но не и во VC каде што гардероберот е премногу мал и има само со една врата. 


\subsection{3 Простор за дневен престој и спиење}

\begin{tabular}{|c|c|c|c|c|}
\hline & $\begin{array}{l}\text { Препораки за просторот за дневен престој и спиење во } \\
\text { станбена единица }\end{array}$ & H. H. & V.C. & M. T. \\
\hline 1 & $\begin{array}{l}\text { Во дневната/спалната соба да има предвидено место со } \\
\text { приклучок за ТВ уред. }\end{array}$ & $\checkmark$ & $\sqrt{ }$ & $\checkmark$ \\
\hline 2 & Во близина на ТВ уредот да има место за удобно седење. & $\checkmark$ & $\mathrm{X}$ & $\mathrm{x}$ \\
\hline 3 & $\begin{array}{l}\text { Во дневната/спалната соба да има слободен простор со } \\
\text { дијаметар од 1500мм за завртување на инвалидска количка. }\end{array}$ & $\checkmark$ & $\checkmark$ & $\mathrm{X}$ \\
\hline 4 & Во дневната/спалната соба да има природна светлина. & $\checkmark$ & $\checkmark$ & $\checkmark$ \\
\hline 5 & $\begin{array}{l}\text { Висината на парапетот на прозорот во дневната/спалната соба да } \\
\text { биде под 600мм. }\end{array}$ & $\checkmark$ & $\mathrm{x}$ & $\checkmark$ \\
\hline 6 & $\begin{array}{l}\text { Да бидат достапни ролетни за затемнување на просторот, кои ќе } \\
\text { го покриваат целиот прозор и станарот ке може лесно да ги } \\
\text { помести. }\end{array}$ & $\checkmark$ & $\checkmark$ & $\mathrm{x}$ \\
\hline 7 & $\begin{array}{l}\text { Дневната/спалната соба да има природна вентилација, т.е. } \\
\text { прозорот да може да се отвори. }\end{array}$ & $\checkmark$ & $\checkmark$ & $\checkmark$ \\
\hline 8 & $\begin{array}{l}\text { Осветлувањето во дневната/спалната соба да биде рамномерно } \\
\text { распространето низ просторот без да создава длабоки сенки. }\end{array}$ & $\checkmark$ & $\mathrm{H} / \Pi$ & $\mathrm{X}$ \\
\hline 9 & $\begin{array}{l}\text { Електричната светилка во дневната/спалната соба да биде } \\
\text { прикриена. }\end{array}$ & $\sqrt{ }$ & $\checkmark$ & $\sqrt{ }$ \\
\hline 10 & Во дневната/спалната соба да има детектор за чад. & $\checkmark$ & $\checkmark$ & $\mathbf{x}$ \\
\hline 11 & $\begin{array}{l}\text { Дневната/спалната соба да биде декорирана во светли бои и без } \\
\text { сјајни површини. }\end{array}$ & $\checkmark$ & $\checkmark$ & $\checkmark$ \\
\hline 12 & Да има директен пристап од креветот до тоалетот. & $\checkmark$ & $\checkmark$ & $\checkmark$ \\
\hline 13 & Вратата од тоалетот да може да се види од креветот. & $\checkmark$ & $\mathrm{x}$ & $\mathrm{x}$ \\
\hline 14 & Креветот да може да се помести во повеќе од една позиција. & $\checkmark$ & $\checkmark$ & $\mathrm{X}$ \\
\hline 15 & Да има повеќе од 1500мм на една од страните на креветот. & $\checkmark$ & $\checkmark$ & $\checkmark$ \\
\hline 16 & Да има место за најмалку едно ноќно шкафче до креветот. & $\checkmark$ & $\checkmark$ & $\checkmark$ \\
\hline 17 & $\begin{array}{l}\text { Во спалниот простор да може да се постави креденец со фиоки } \\
\text { (може под ТВ уредот). }\end{array}$ & $\sqrt{ }$ & $\checkmark$ & $\checkmark$ \\
\hline \multirow[t]{2}{*}{18} & $\begin{array}{l}\text { Над или до креветот да има доволен простор за монтирање на } \\
\text { дигалка (плафонска или самостојна). }\end{array}$ & $\checkmark$ & $\checkmark$ & $\checkmark$ \\
\hline & На sидот до креветот да има алармен уред за повик. & $\checkmark$ & $\checkmark$ & $\checkmark$ \\
\hline 19 & $\begin{array}{l}\text { Штекерите во спалната соба да бидат поставени на височина } \\
\text { 450-1200мм од подот и да бидат лесно пристапни, без да се } \\
\text { поместува мебел. }\end{array}$ & $\checkmark$ & $\checkmark$ & $\mathrm{X}$ \\
\hline 20 & Прекинувачи за светло - на височина 1000-1200мм од подот. & $\checkmark$ & $\checkmark$ & $\checkmark$ \\
\hline
\end{tabular}

Табела 11 - Препораки за просторот за дневен престој и спиење во станбена единица. Извор: авторот. 
Бидејќи во текстот се говори за еднособени станбени единици каде што просторот за спиење и дневниот простор не се физички одделени, препораките кои се однесуваат за дневна и спална соба а се еднакви, се споени во една заедничка препорака запишана како „простор за дневен престој и спиење“.

\section{ПРИВАТНОСТ}

Како што веќе беше споменато во Воведот на стр. 11, помеѓу најчестите симптоми на лицата со АБ се промена на расположението, вознемиреност и депресија. Од тие причини, станбените единици покрај место за спиење треба да овозможат и место каде станарите ќе можат да се повлечат кога ќе се чувствуваат непријатно и ќе читаат, гледаат телевизија, ќе поминуваат време со своите посетители или ќе изведуваат други активности поврзани со одмор. Ова е во согласност со образложувањето на Regnier и Denton (2009) според кое кога станарот има свое катче во кое може да се повлече доколку нема желба да социјализира со останатите станари тогаш ќе помогне во намалување на нивото на стрес и вознемиреност. Regnier и Denton (2009, р.187) понатаму препорачуваат станбената единица во домовите да биде ,наменета само за еден станар и да биде доволно голема да смести кревет, маса, кауч и ТВ уред“.

Davis, Byers, Nay и Koch (2009) презентираат неколку начини кои ја зголемуваат приватноста на личниот простор на лицата со деменција во станбените единици, помеѓу кои - присуството на семејни фотографии, лични предмети и личен мебел кои содржат некаква интимна асоцијација за станарот (Davis, Byers, Nay \& Koch, 2009). Сето тоа, како што велат Davis, Byers, Nay и Koch (2009) помага во создавањето на чувство за поседување на својот простор во домот.

Во снимените станбени единици во домот НН мебелот и декоративните елементи беа

донесени од семејството на станарот со исклучок на креветот, бидејќи се работи за медицински кревет на тркала со регулатор на висината. Во домовите МТ и НН беше забележано присуството на ТВ уред, додека во снимената станбена единица во домот VC немаше ТВ уред меѓутоа наспроти креветот имаше предвидено место со приклучок за ТВ уред. Во МТ ТВ уредот беше поставен на ноќно шкафче наспроти двата кревети (слика 
21), додека во НН се наоѓаше на комода наспроти местото за седење покрај креветот (слика 22).

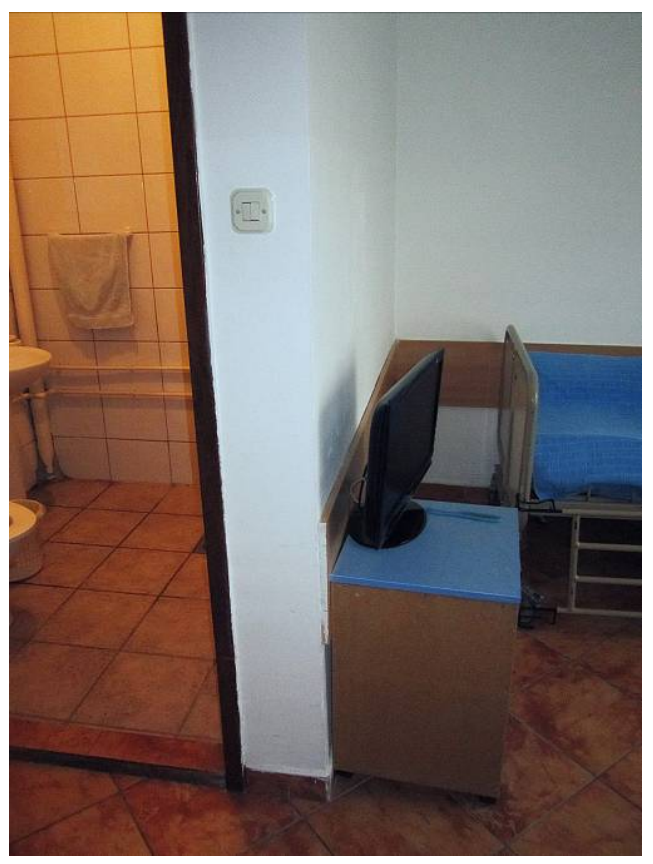

Слика 21 - Место за ТВ уред во станбената единица на домот МТ. Извор: авторот.

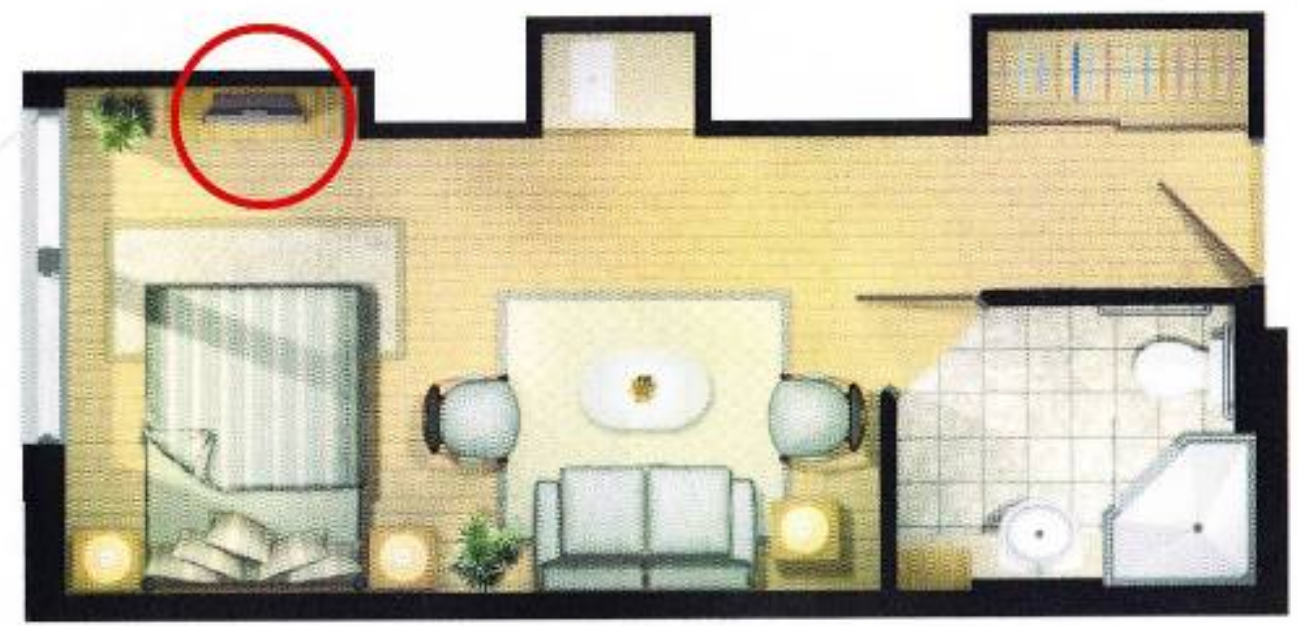

Слика 22 - Место за ТВ уред во станбената единица на домот НН. Извор: авторот

Поради проблемите со меморијата со кои се соочуваат лицата со АБ, тоа што не го гледаат пред своите очи најчесто не знаат дека постои (Regnier, 2002). Regnier (2002) 
објаснува дека станарите со деменција кога гледаат во затворена врата пред себе не знаат што би требало да има зад неа, но истата конфузија се случува и кога се обидуваат да најдат нешто низ својата соба. Од овие причини Regnier (2002) препорачува да се

употребуваат шкафови со стаклени врати за складирање на предмети кои станарот ги користи, а исто така на неговата препорака може да се додаде и оставањето на предмети на рафтови се додека со тоа не се создава неред во просторијата. Како дополнување на препораката на Regnier за шкафови со стакло, мора да се напомене дека треба да се внимава при употребата на мебел кој содржи стакло поради особината на создавање на одблесок во просторот. Затоа треба да бидат поставени на место каде што нема директно насочена светлина или да се употребува стакло со анти-рефлексивен слој.

Додека во станбените единици на домот НН имаше предвидено катче за дневен престој, во домовите MT и VC немаше, иако во суштина просторот во единиците може да го дозволи тоа. Единствената карактеристика во МТ која наликуваше на катче за дневен престој беше присуството на едно столче помеѓу креветите насочени кон телевизорот. Овој начин на седење повеќе наликува на седење на посетител или негувател во соба за интензивна нега. Можните модификации за подобрување на условите за седење во станбената единица на станарите во домот МТ ќе се разгледа подетално во следното поглавје.

\section{ПРИСТАПНОСТ И БЕЗБЕДНОСТ}

Покрај удобноста и домашниот изглед, други фактори на кои треба да се внимава при уредувањето на просторот наменет за лица со АБ е безбедноста. Помеѓу најважните безбедносни аспекти на уредувањето се спречување на паѓањето и олеснување на мобилноста на станарите. Бидејќи старите лица многу често имаат проблеми со мобилноста како последица од повреда при паѓање, веројатно е некој од станарите за време на својот престој во домот да има потреба од помошно мобилно средство (како инвалидска количка, одалка и сл.). Ова е појаснето со објаснувањето на Gitlin и Cheе (2006, р.32) според кое „од средниот кон третиот стадиум на болеста, лищата со АБ во принции имаат потреба од помош со секојдневните активности како што се преместувањето од и во кревет, столица или тоалет, капењето, облекувањето, 
хранењето и личната нега“. Од тие причини, просторот треба да дозволи непречено движење на станарот кој користи помагала за движење.

Додека во станбените единици на домовите НH и VC има можност за прикачување на статични плафонски и на поставување на самостојни дигалки, во домот МТ нема можност за плафонска дигалка поради тоа што станбените единици се наоѓаат на поткровје и закосениот кров не дозволува монтажа на дигалки од ваков вид. Поради тоа, просторот околу креветот треба да овозможи доволно место за пристап со самостојна дигалка, коешто беше овозможено во сите три домови.

До креветот во сите снимени домови имаше алармен уред за повик на помош, со таа разлика што уредот во домот НН имаше и домофон (слика 23) додека во МТ (слика 24) и VC (нема фотографија) беше само копче

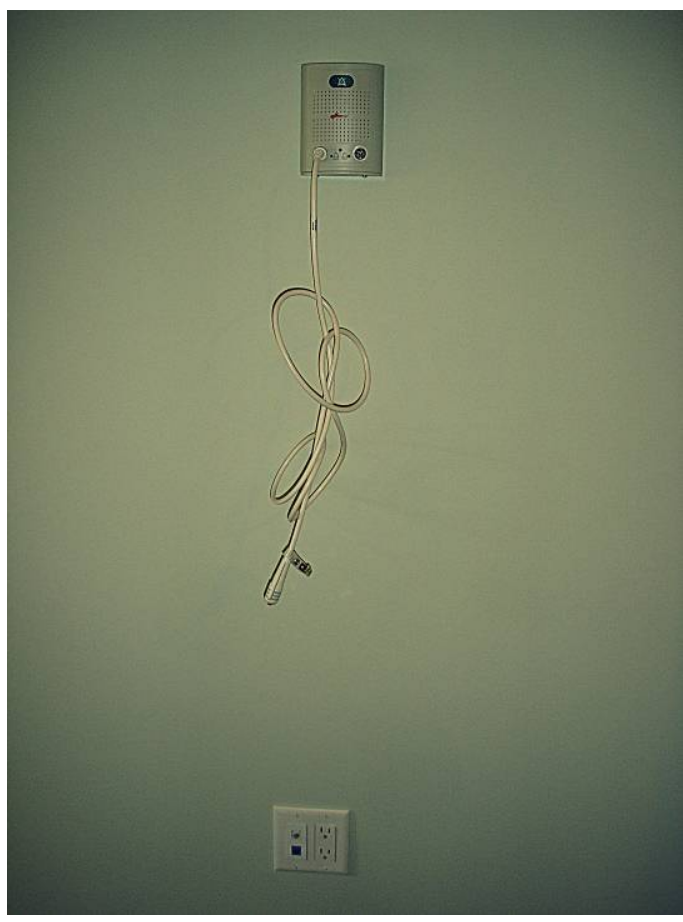

Слика 23 - Алармен уред за повик на помош во станбената единица во домот НН. Извор: авторот. 


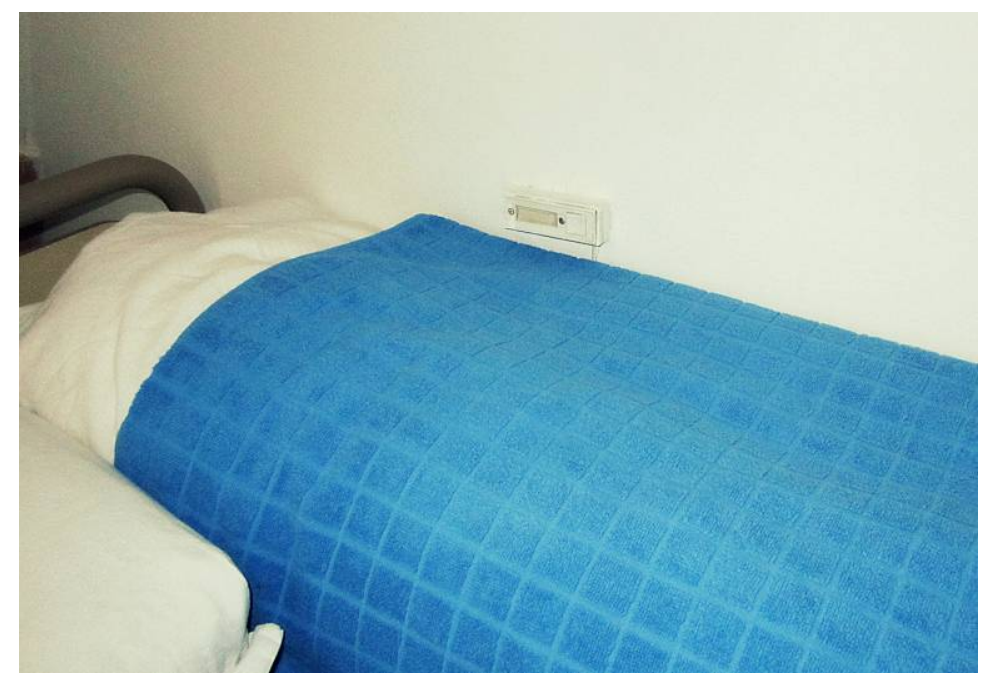

Слика 24 - Алармен уред за повик на помош во станбената единица во домот Мт Извор: авторот.

Често сретнувана препорака во станбената единица, која што повторно се однесува на пристапноста во просторот, е препораката за слободен простор во дневниот и спалниот простор со дијаметар од 1500мм за завртување на инвалидска количка (City of Toronto, 2004; Министерство за транспорт и врски, 2010). Во снимените станбени единици во домовите НН и VC оваа препорака беше применета, меѓутоа во домот МТ слободниот просторот е помал од препорачаното, што може да се види на Слика 25.

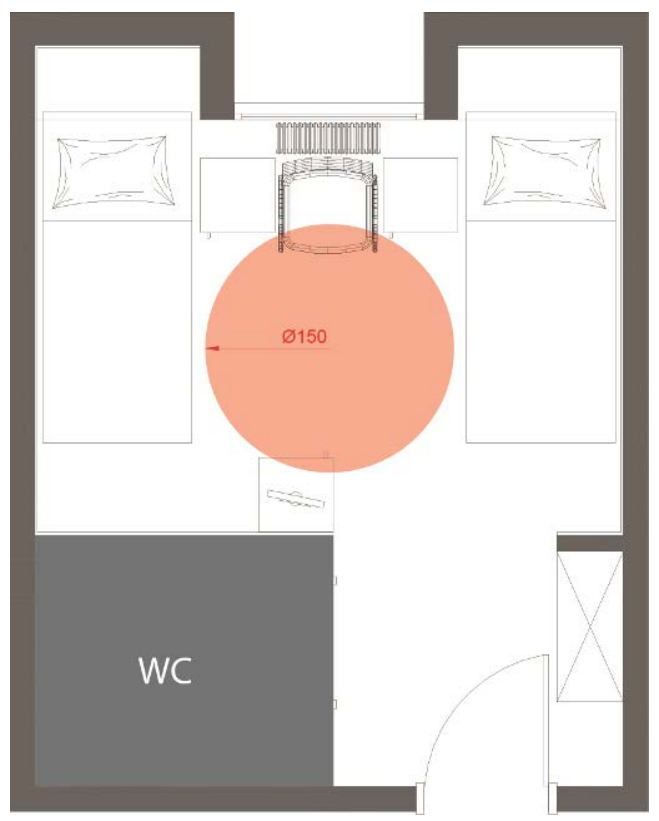

Слика 25 - Дијаметар од 1500мм за завртување на инвалидска количка во станбената единица на МТ. Извор: авторот 


\section{ОСВЕТЛУВАЫЕ И БОЈА}

Бидејќи примената на конкретна боја во просторот се сведува на лични преференции и не е економски издржано sидовите во станбените единици да се пребојуваат според желбите на секој нов станар, логично е да се употребат светли тонови од ненаметливи бои кои што ќе претставуваат неутрална позадина и нема да му пречат на станарот. Исто така, неутралните тонови полесно ќе се комбинираат со бојата на личниот мебел на станарот кој, по успешниот пример на домот $\mathrm{HH}$, се охрабрува да биде донесен во станбените единици. Според Brawley (2006) кога сите станбени единици се еднакво обоени просторот добива институционален изглед. Во тој случај, можеби би било интересно доколку секоја станбена единица биде обоена со боја во поинаков тон.

Нискиот прозорски парапет во домот $\mathrm{HH}$ ја полнеше просторијата со природна светлина и создаваше можност за седење до прозор со поглед кон надворешниот свет. Покрај природното осветлување и главното плафонско осветлување поставено на средина на просторот, во станбената единица имаше дополнителни светлосни извори кои веројатно беа сопственост на станарите. Ова придонесува во создавањето на домашен изглед во просторот. Исто така и во станбените единици во домот МТ имаше прозорец со низок парапет кој имаше помала плоштина од прозорецот во $\mathrm{HH}$, но сепак се работи за станбена единица која е помала за околу $15 \mathrm{~m}^{2}$ од станбената единица на НН.

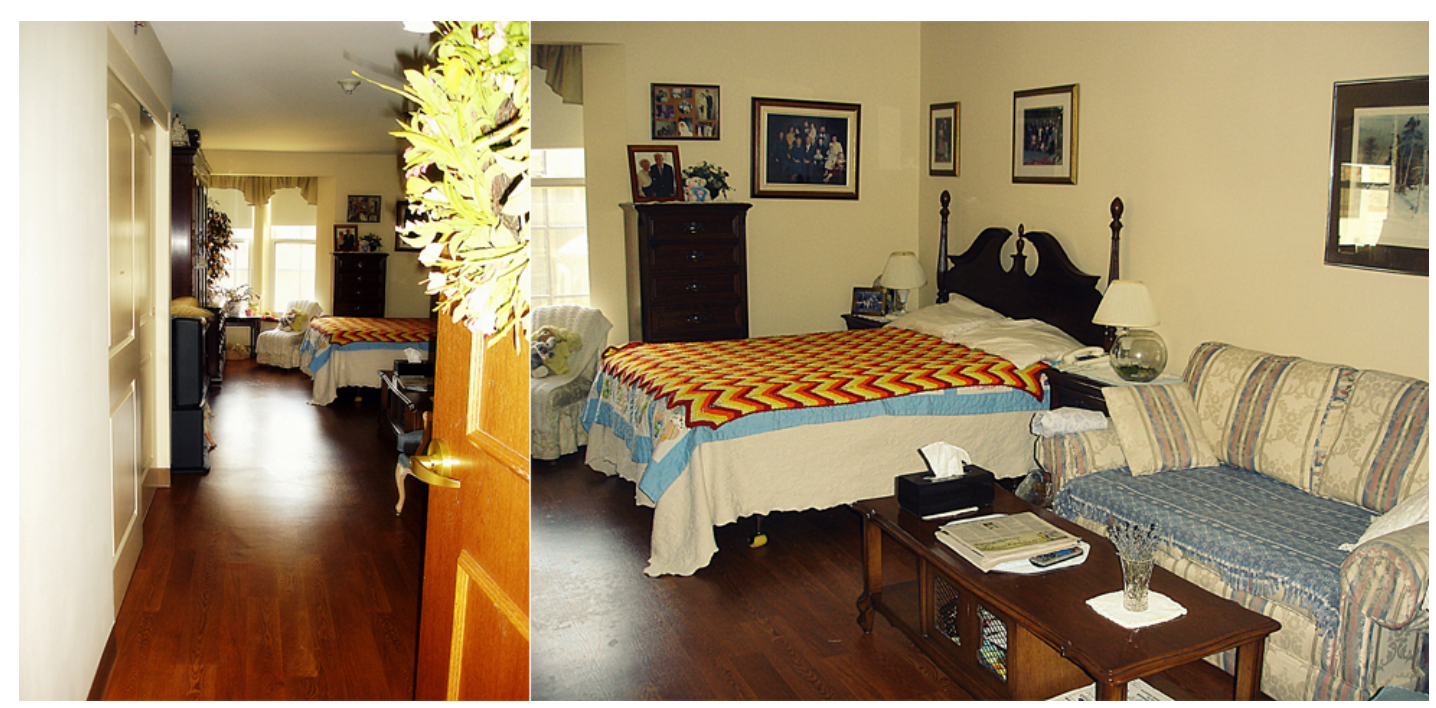

Слика 26 - Креветот и катчето за дневен престој во станбената единица на домот НН. Извор: авторот 


\section{ОРИЕНТАЦИЈА}

Бидејќи помеѓу подоцнежните карактеристики на АБ се вбројуваат збунетоста и дезориентацијата (Alzheimer’s Association, 2011), позиционирањето низ просторот на точките од интерес за станарот е од големо значење за намалување на овие симптоми. Најчесто споменувани места каде што станарите вообичаено се дезориентираат или потешко се снаоѓаат, се ходниците и пронаоѓањето на тоалетите во станбените единици или надвор од станбените единици (заедничкиот тоалет). Кога се говори за потешкотии при пронаоѓање на тоалетите во станбените единици, забележано е дека тоа најчесто се случува навечер кога се будат поради потребата за користење на тоалетот. Buzink et al. (2005, р.18) при интервјуирање на шест професионални негуватели увиделе дека рутинското „придвижување до и од тоалетот претставува една од најопасните активности кои се одвиваат во тоалетите“. Покрај тоа што вечерното движење е опасно за станарот, тоа претставува дополнителна ангажираност на негувателите во вечерните часови.

Во статија на списанието Long-Term Living (Taylor, 2005) опишано е истражување спроведено од Lighting Research Center кои ја тестирале употребата на жолтеникаво LED осветлување во вид на ленти прикачени околу пределите кои станарите ги користат во доцните ноќни часови кога се разбудени од потребата за тоалет. Помеѓу споменатите предели на кои биле поставувани LED лентите се: „под рамката на креветот (во близина на подот), околу рамката на вратата од тоалетот, под огледалото и под држачот за раце во тоалетот“ (Taylor, 2005, p.1). Осветлувањето било контролирано со фотосензори кои го вклучувале светлото само кога собата била темна, но и со сензори на движење кои постепено ја вклучувале светлината кога станарот ќе се придвижел кон тоалетот во вечерните часови или кога негувателите ќе ја отвореле вратата навечер за да го проверат станарот. Резултатите од тестирањето биле позитивни и станарите биле задоволни од ова решение за ноќното будење. Сепак, за истражувањето биле испитани мал број на станари и негуватели, но овој начин за суптилно ноќно осветлување на потребните места можеби ќе го реши проблемот со ноќното талкање и несоницата кај станарите поради што вреди понатаму да се доразгледа. 
Brawley (2006, р.195) ја истакнува видливоста на вратата на тоалетот од креветот на станарот како многу значајна препорака којашто треба да му помогне на станарот во лоцирање на тоалетот за време на вечерните часови. Од трите снимени домови, овој начин на позиционирање на тоалетите во станбените единици беше присутен само во НН (слика 26). Во останатите домови влегувањето во тоалетот беше од страната на претсобјето, коешто е прикажано на дијаграмите на слика 27.

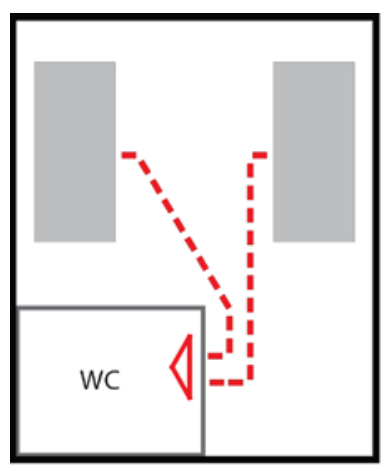

Мери Терзиева

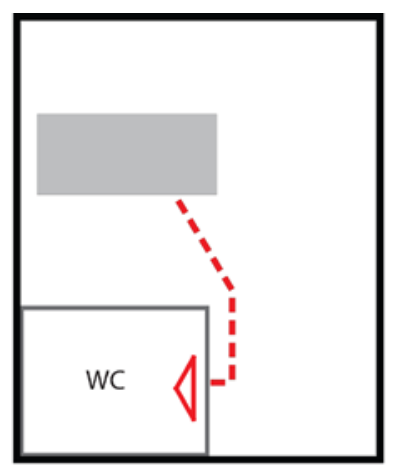

Villa Colombo

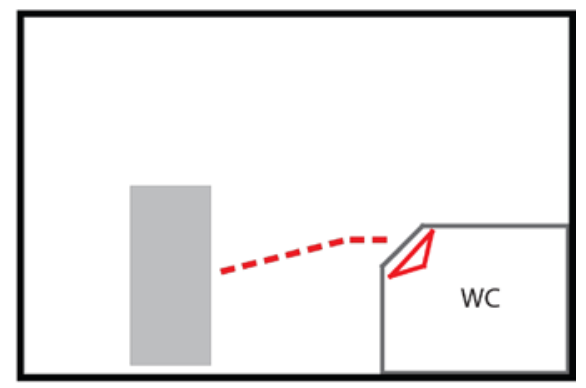

Humber Heights

Слика 27 - Дијаграми со линии на движење на станарите од креветот до тоалетот во станбените единици. Извор: авторот.

Во домот МТ само едниот од креветите има јасна линија на движење. Доколку се тргне другиот кревет со цел да се направи еднокреветна станбена единица за лица со АБ (со катче за седење во левиот агол) тогаш ќе остане само десниот кревет од којшто може да се види вратата на тоалетот (слика 28). На истиот начин може да се помести и креветот во станбената единица на VC, со разликата што тој би ја задржал хоризонталната положба. 


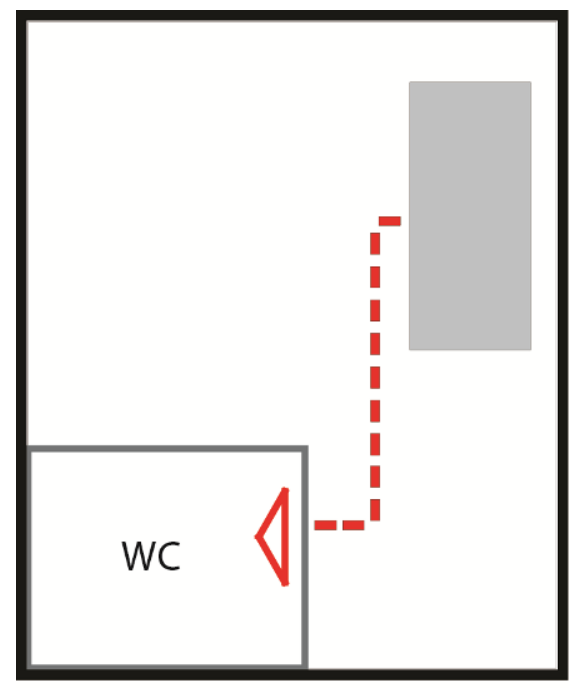

Мери Терзиева

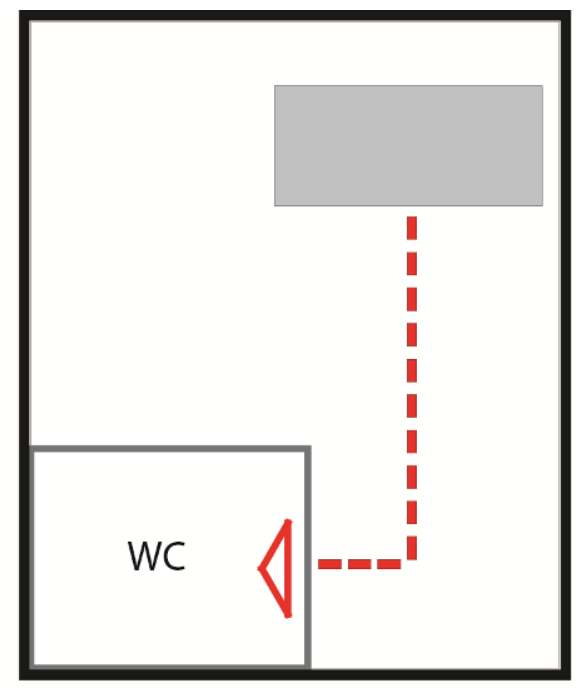

Villa Colombo

Слика 28 - Дијаграми со модификации на линиите на движење на станарите од креветот до тоалетот во станбените единици на МТ. Извор: авторот.

\section{Предлози извлечени од прегледаната литература на темата}

Дневна и спална соба
Предметите кои станарот често ги користи или коишто треба да ги користи да бидат
поставени на видно место како на пример на полици, или во шкафови со стаклени врати
(само ако шкафовите со стаклени врати се поставени на начин што нема да се создава
одблесок на светлина од стаклото или ке се употреби стакло кое не создава одблесок).
(Regnier, 2002, р. 142)

Табела 12 - Предлози за просторот за дневен престој и спиење извлечени од прегледаната литература. Извор: авторот. 


\subsection{4 Тоалет}

\begin{tabular}{|c|c|c|c|c|}
\hline & Препораки за тоалет во станбена единица & H. H. & V.C. & M. T. \\
\hline 1 & $\begin{array}{l}\text { Во тоалетот да има слободен простор со дијаметар од 1500мм } \\
\text { за завртување на инвалидска количка. }\end{array}$ & $\checkmark$ & $\checkmark$ & $\mathrm{x}$ \\
\hline 2 & $\begin{array}{l}\text { Вратата од тоалетот да биде во боја контрастна на sидот кој ја } \\
\text { опколува. }\end{array}$ & $\checkmark$ & $\mathrm{x}$ & $\checkmark$ \\
\hline 3 & $\begin{array}{l}\text { Вратата од тоалетот да нема одблесок (употреба на матни бои } \\
\text { и премази). }\end{array}$ & $\checkmark$ & $\checkmark$ & $\mathrm{x}$ \\
\hline 4 & $\begin{array}{l}\text { Кваките на вратите да бидат лесни за употреба (препознатлив } \\
\text { начин на отворање). }\end{array}$ & $\checkmark$ & $\sqrt{ }$ & $\checkmark$ \\
\hline 5 & $\begin{array}{l}\text { Вратата од WC-то да има широчина на светлиот отвор од } \\
\text { најмалку 900мм и да се отвара на надвор. }\end{array}$ & $\checkmark$ & $\checkmark$ & $\mathrm{x}$ \\
\hline 6 & Прагот на вратата да биде порамнет со подот. & $\checkmark$ & $\checkmark$ & $\mathrm{x}$ \\
\hline 7 & Тоалетот да има туш наместо када. & $\sqrt{ }$ & $\mathrm{H} / \Pi$ & $\checkmark$ \\
\hline 8 & Тушот да биде лоциран на спротивниот sид од вратата. & $\checkmark$ & $\mathrm{H} / \Pi$ & $\sqrt{ }$ \\
\hline 9 & Во тушот да има водоотпорно седиште. & $\checkmark$ & $\mathrm{H} / \Pi$ & $\mathrm{x}$ \\
\hline 10 & Во тушот да има држач за раце. & $\checkmark$ & $\mathrm{H} / \Pi$ & $\mathrm{x}$ \\
\hline 11 & Славината во тушот да биде еднорачна. & $\checkmark$ & $\mathrm{H} / \Pi$ & $\sqrt{ }$ \\
\hline 12 & Зад WC шолјата да бидат монтирани држачи за раце. & $\checkmark$ & $\checkmark$ & $\mathrm{X}$ \\
\hline 13 & До WC шолјата да бидат монтирани држачи за раце. & $\sqrt{ }$ & $\checkmark$ & $\checkmark$ \\
\hline 14 & $\begin{array}{l}\text { Тоалетната шолја да може да биде достигната со странично } \\
\text { префрлување од инвалидска количка. }\end{array}$ & $\mathrm{x}$ & $\checkmark$ & $\mathrm{x}$ \\
\hline 15 & Околу мијалникот да има држачи за раце. & $\mathrm{x}$ & $\checkmark$ & $\mathrm{x}$ \\
\hline 16 & Мијалникот во тоалетот да биде висечки. & $\checkmark$ & $\checkmark$ & $\mathrm{x}$ \\
\hline 17 & Славината од мијалникот да биде еднорачна. & $\checkmark$ & $\checkmark$ & \\
\hline 18 & $\begin{array}{l}\text { Над мијалникот да има огледало кое може да се користи и од } \\
\text { лице во седната положба. }\end{array}$ & $\checkmark$ & $\checkmark$ & $\mathrm{x}$ \\
\hline 19 & $\begin{array}{l}\text { До мијалникот да има доволно место за оставање на предмети } \\
\text { за лична хигиена. }\end{array}$ & $\checkmark$ & $\checkmark$ & $\mathrm{x}$ \\
\hline 20 & Во близина на мијалникот да има ормарче за козметика. & $\checkmark$ & $\checkmark$ & $\mathrm{x}$ \\
\hline 21 & Над мијалникот да биде поставено насочено осветлување. & $\checkmark$ & $\checkmark$ & $\mathrm{x}$ \\
\hline 22 & Да биде поставено светло над туш кабината. & $\checkmark$ & $\mathrm{H} / \Pi$ & $\mathrm{x}$ \\
\hline 23 & Да нема присуство на непокриени електрични светилки. & $\checkmark$ & $\checkmark$ & $\sqrt{ }$ \\
\hline 24 & $\begin{array}{l}\text { До огледалото во тоалетот да има електричен приклучок, } \\
\text { поставен на височина од } 1000 \text { до 1100мм од подот. }\end{array}$ & $\checkmark$ & $\checkmark$ & $\mathrm{x}$ \\
\hline 25 & Во тоалетот да има уред за повик. & $\checkmark$ & $\checkmark$ & $\mathrm{x}$ \\
\hline 26 & $\begin{array}{l}\text { Тоалетот е декориран во светли тонови и матни површини (да } \\
\text { нема одблесок). }\end{array}$ & $\sqrt{ }$ & $\mathrm{x}$ & $\mathrm{x}$ \\
\hline 27 & Подот во тоалетот јасно да се разликува од тоалетната опрема. & $\checkmark$ & $\checkmark$ & $\checkmark$ \\
\hline
\end{tabular}




\begin{tabular}{|c|l|c|c|c|}
\hline 28 & Сидовите во тоалетот јасно да се разликуваат од подот. & $\checkmark$ & $\checkmark$ & $\checkmark$ \\
\hline 29 & Опремата во тоалетот јасно да се разликува од зидовите. & $\checkmark$ & $\mathrm{x}$ & $\mathrm{x}$ \\
\hline 30 & $\begin{array}{l}\text { Површините во тоалетот (подот, сидовите, ормарот) да немаат } \\
\text { рефлексија. }\end{array}$ & $\checkmark$ & $\checkmark$ & $\mathrm{x}$ \\
\hline 31 & Подот во тоалетот да не е лизгав. & $\checkmark$ & $\checkmark$ & $\mathrm{x}$ \\
\hline 32 & Држачите за раце да немаат болнички изглед. & $\checkmark$ & $\mathrm{x}$ & $\checkmark$ \\
\hline 33 & $\begin{array}{l}\text { Прекинувачите за светло да бидат на височина од 1000 до } \\
\text { 1200мм од подот. }\end{array}$ & $\checkmark$ & $\mathrm{H} / П$ & $\mathrm{H} / П$ \\
\hline
\end{tabular}

Табела 13 - Препораки за тоалетот во станбена единица. Извор: авторот.

\section{ПРИСТАПНОСТ И БЕЗБЕДНОСТ}

Голем број од прашањата во евалуацијата EVOLVE се однесуваат за овозможување на непречен пристап за старите лица во тоалетот, но и за безбедна употреба на просторот од страна на станарот. Тоалетите се сметаат за едни од најопасните простори во кои најчесто се случуваат несреќи (Buzink et al., 2005; Wang \& Shepley, 2008; Regnier \& Denton, 2009).

Тоалетите во домовите за стари лица со пречки во помнењето треба да ги поттикнат станарите да продолжат да ги изведуваат секојдневните активности за лична нега и хигиена кои ги правеле досега. Поради тоа, во овој простор треба јасно да се издвојуваат потребните елементи и опрема за лична хигиена и да се овозможи максимална безбедност при изведување на истите активности. И овде треба да се повтори препораката на Regnier (2002), спомената во 5.2.3 на страна X, за поставување на предметите кои станарите треба да ги користат во провидни шкафови или на полици со што станарот ќе ги забележи а со тоа и употреби. Ова е важно од причина што лицата со АБ многу често ги забораваат дури и активностите од секојдневниот живот, како користење на тоалетот (Regnier, 2002). Полезен метод за суптилно потсетување на станарот за посета на тоалетот којшто Regnier (2002) го предлага како еден од поуспешните начини за справување со инконтиненцијата на станарите е инсталирање на сензорно вклучување на светлото во тоалетот коешто ќе се вклучи кога станарот ќe поминува покрај тоалетот и со тоа ќe го привлече внатре.

Првиот аспект од безбедноста и пристапноста на тоалетот во домот МТ кој беше забележан за време на снимањето на објектот беше присуството на праг на влезот во тоалетот (слика 29). Додека тоалетите во другите два домови немаа праг на влезот, МТ беше единствениот пример со оваа појава. Иако во тоалетот на снимената станбената единица во домот НН немаше праг на влезот, сепак беше забележано цокле на туш 
кабината кое го попречува влезот во кабината за станарите со инвалидска количка (слика 30).

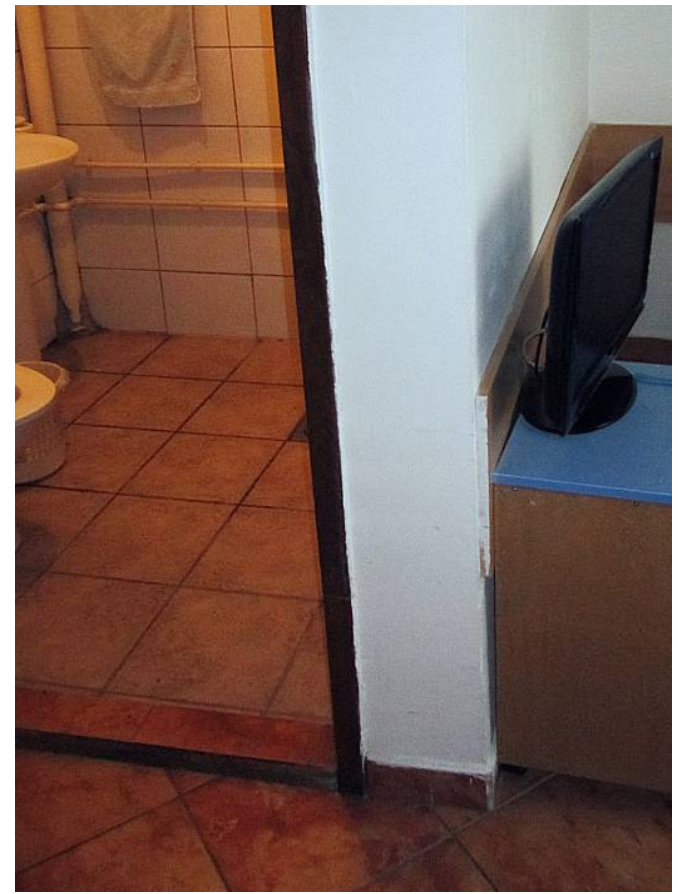

Слика 29 - Појава на праг на влезот од тоалетот во станбената единица во домот МТ. Извор: авторот.

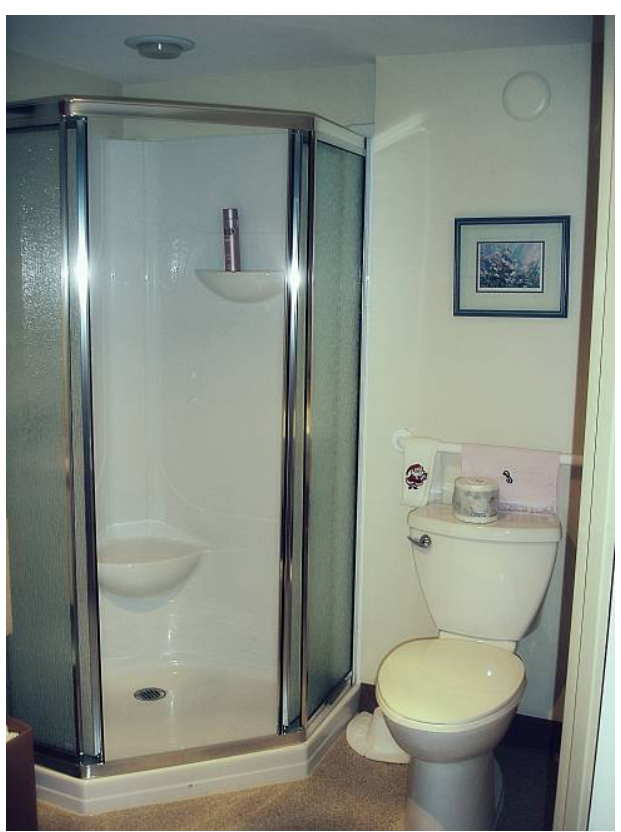

Слика 30 - Тоалетот во станбената единица во домот НН. Извор: авторот. 
Дополнително на тоа, туш кабината немаше можност за присуство на негувател за време на туширањето поради преградата со која беше заградена. Меѓутоа, домот НН содржеше дополнителен „тоалет со помош“ (assisted bathroom) во кој лицата со ограничена мобилност можат да бидат искапени со помош на негувателите. Како што може да се забележи од слика 31, во тоалетот во станбената единица на VC воопшто немаше туш туку имаше само тоалетна шолја, мијалник и складишен простор. Ова е поради причината што станарите се капат со помош на негувателите во „пристапниот тоалет“.
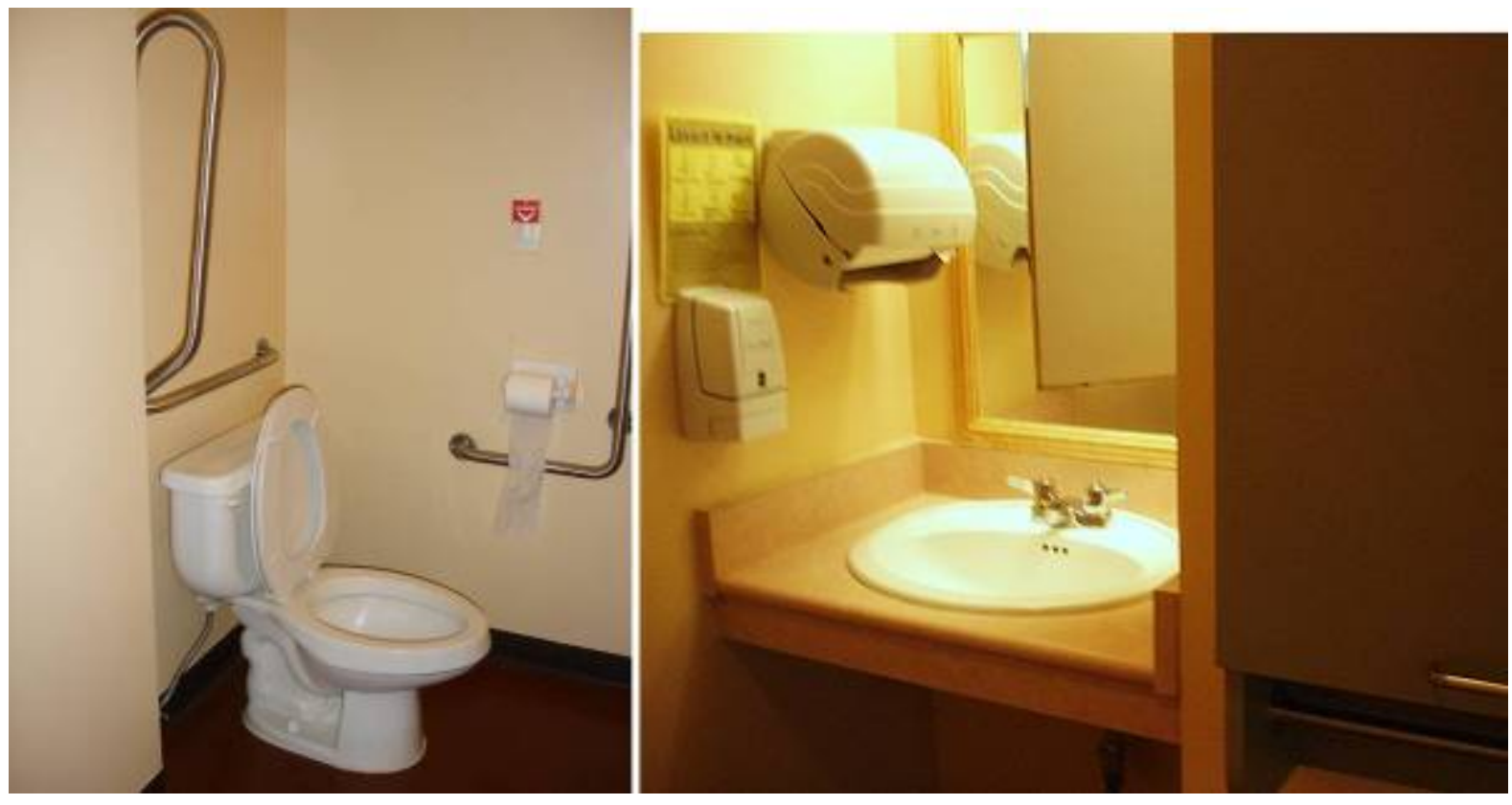

Слика 31 - Тоалетот во станбената единица во домот VC. Извор: авторот.

Покрај тезата за опасноста при движењето до тоалетот, како подеднакво опасна активност се издвојува и завртувањето пред тоалетната шолја по употребата (Buzink et al., 2005). Ова ја потенцира потребата од поставување на држачи за раце околу тоалетната шолја за кои станарот ќе може да се придржи доколку ја загуби рамнотежата. Gitlin, Miller и Boyce (in Buzink et al., 2005) истакнуваат дека од можните начини за потпомагање на станарите при движење низ просторот на второ место по употреба се оние употребувани во тоалетите. За ова Regnier (2002) опоменува дека стандардите за држачи за раце кои обично се превземаат од оние наменети за лицата со хендикеп не соодветствуваат за старите лица поради разликата во препорачаните височини. Според него најуспешно е 
вертикалното поставување на држачи за раце до тоалетната шолја и тушот, како и држачи за раце со променлива височина.

Како што може да се забележи на фотографиите од тоалетот во станбените единици на VC на sидовите околу тоалетот се поставени сите неопходни држачи за раце. Единствено што нивниот изглед е груб и има институционален карактер.

Regnier и Denton (2009) во своето истражување како најповолен начин за туширање во станбените единици во домовите го посочуваат примерот кој го забележале во северна Европа каде што целата подна површина во тоалетот е на едно ниво со нагиб, а пределот на тушот е само во еден агол каде станарите со инвалидска количка можат лесно да пристапат. Сличен на овој пример е случајот со тоалетот во домот МТ. Меѓутоа површината на тоалетот во МТ не соодветствува со најчесто сретнуваната препорака за тоалет со дијаметар од слободен простор (чист дијаметар, без мебел или опрема) за завртување на инвалидска количка кој изнесува 1500мм (City of Toronto, 2004; Ministry of Health and Long-Term Care, 2009). Оваа состојба може да се забележи од дијаграмот на Слика 32.

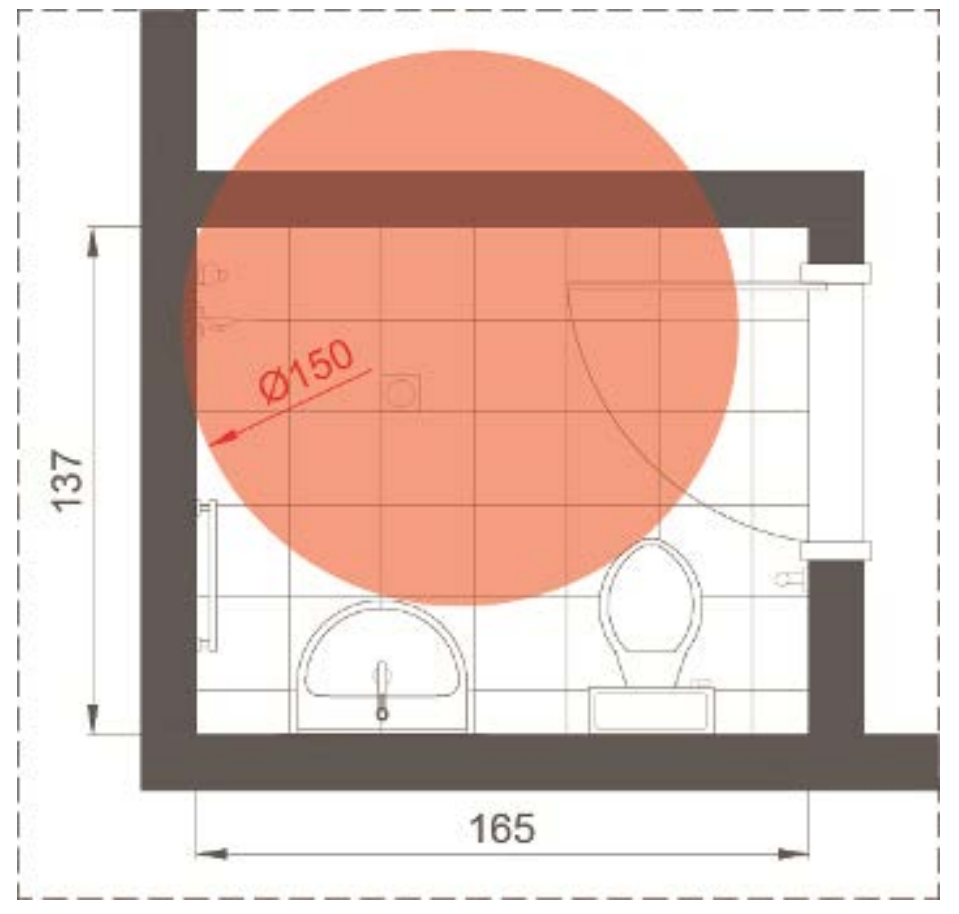

Слика 32 - Дијаграм којшто го прикажува препорачаниот дијаметар на слободен простор од 1500мм нанесен врз површината на тоалетот во МТ. Извор: авторот. 
Друг аспект на безбедност кој може да претставува дополнителна опасност во тоалетот на МТ е причината што околу пределот на тушот нема преграда или завеса, што всушност може да претставува опасност бидејќи водениот под може да предизвика лизгање и паѓање при што станарите можат сериозно да се повредат.

\section{ОСВЕТЛУВАНЕ И БОЈА}

Torrington и Tregenza (2007) предупредуваат дека особено внимание во осветлувањето на просторот за лица со деменција треба да се посвети во тоалетите и тушот каде што станарите најчесто ги вадат своите очила со што се намалува видливоста во просторот а со тоа и нивната безбедност. Согласно со препораките на АКЕ (2010), над огледалото во тоалетот добро е да има насочено светло кое ќе ги елиминира сенките на лицето и ќе овозможи станарите подобро да го гледаат својот одраз во огледалата. Исто и во пределот на тушот во тоалетите да се предвиди индиректно осветлување (ламби со водоотпорни капаци) кое ќе го осветлува станарот за време на капењето.

\section{Поуки извлечени од прегледаната литература на темата}

Тоалет
Употреба на LED ленти со жолтеникаво светло прикачени околу пределите кои станарите
ги користат во доцните ноќни часови (под креветот, околу рамката на вратата од тоалетот,
над мијалникот или под огледалото и под држачите за раце во тоалетот) кога се разбудени
од потребата за тоалет. (Тауlor, 2005)
Повеке се препорачува употребата на самостоен стол за капење отколку монтирање на
седишта поради нивната флексибилност и способност за поместување по потреба. (Regnier,
2002)
Светло во тоалетот кое ќ се вклучува преку сензор на движење со цел да го потсети
станарот да влезе внатре. (Regnier, 2002)
Да се постави тоалетен капак со темна боја која ќе биде во контраст со тоалетната шолја.
(Rеgniег, 2002)


Доколку нема централно греење во тоалетот да се постави греалка која се монтира на sид со цел брзо загревање на тоалетот пред капење. (Regnier, 2002)

Да се постават регулатори на топлина на водата која истекува од мијалникот и тушот, за да не изгорат станарите од врела вода. (Regnier, 2002)

Табела 14 - Предлози за тоалетот извлечени од прегледаната литература. Извор: авторот.

\section{3 Заеднички простор}

Од заедничкиот простор во домовите за време на посетата беа снимени ходниците и просторот за дневен престој во сите три домови, при што во домот МТ фотографското снимање во просторот за дневен престој не беше возможно поради постојаното присуството на станари. Во домот НН беа снимени неколку дополнителни заеднички содржини од видот на пристапен тоалет, семејна кујна и таканаречените „станищи за животни вештини“. Станиците за животни вештини (life skill stations) Regnier и Denton ги опишуваат како „групащија од мебел (и опрема) која дефинира одредена животна вештина или активност“ (2009, р.175). Одовде може да се разбере дека примената на овој вид на станици ги потсетува станарите на стекнатите вештини и активности во што тие можеби ќе одлучат да земат учество. Поставувањето на различни видови на „станищи на животни вештини“ ќе обезбеди анимирање на станарите од двата полови или станарите со различен интерес и карактер. Истото може да се надоврзе и со останатите заеднички содржини во домот. Според Zeisel et al. (in Zeisel, 2005, p.278) кога постои избор на неколку различни заеднички места во домот ,каде во секое време можат да се приклучат станарите, ќе се намали појавата на социјална изолација. 


\subsection{1 Комуникациски врски помеѓу станбените единици и заедничкиот простор}

\begin{tabular}{|c|c|c|c|c|}
\hline & Препораки за ходниците во домот МT & H. H. & V.C. & M. T. \\
\hline 1 & $\begin{array}{l}\text { Ходниците да бидат доволно широки за да се разминат две } \\
\text { инвалидски колички истовремено (широчина поголема од } \\
\text { 1800мм). }\end{array}$ & $\checkmark$ & $\checkmark$ & $\mathrm{x}$ \\
\hline 2 & $\begin{array}{l}\text { На одредени точки во ходникот да има место за одмор (стол, } \\
\text { клупа, фотелја). }\end{array}$ & $\checkmark$ & $\mathrm{x}$ & $\checkmark$ \\
\hline 3 & $\begin{array}{l}\text { Движењето низ ходникот да се одвива на едно ниво (да нема } \\
\text { разлика во нивото на подот, да нема присуство на скалила и } \\
\text { слични пречки по линијата на движење). }\end{array}$ & $\checkmark$ & $\checkmark$ & $\checkmark$ \\
\hline 4 & $\begin{array}{l}\text { По целата должина на ходниците каде има движење на } \\
\text { станари да бидат поставени држачи за раце. }\end{array}$ & $\checkmark$ & $\checkmark$ & $\mathrm{x}$ \\
\hline 5 & $\begin{array}{l}\text { Држачите за раце да немаат остри и испакнати делови на кои } \\
\text { станарот може да се повреди или да си ја закачи облеката. }\end{array}$ & $\checkmark$ & $\checkmark$ & $\mathrm{x}$ \\
\hline 6 & Држачите за раце да бидат заоблени и со мазна површина. & $\checkmark$ & $\checkmark$ & $\mathrm{X}$ \\
\hline 7 & $\begin{array}{l}\text { Држачите за раце да бидат во боја контрастна на } \\
\text { sидовите/позадината. }\end{array}$ & $\checkmark$ & $\mathrm{x}$ & $\mathrm{X}$ \\
\hline 8 & $\begin{array}{l}\text { Значајни точки по линијата на движење да бидат јасно } \\
\text { означени. }\end{array}$ & $\checkmark$ & $\mathrm{X}$ & $\mathrm{X}$ \\
\hline 9 & $\begin{array}{l}\text { Осветлувањето по ходниците да биде подеднакво } \\
\text { распространето и да нема места со длабоки сенки. }\end{array}$ & $\checkmark$ & $\checkmark$ & $\mathbf{X}$ \\
\hline 10 & $\begin{array}{l}\text { Во ходникот да се избегнува употребата на подни површини } \\
\text { кои предизвикуваат одблесок. }\end{array}$ & $\checkmark$ & $\mathrm{x}$ & $\mathbf{x}$ \\
\hline 11 & $\begin{array}{l}\text { Во ходникот да се избегнува употребата на теписи со крупна } \\
\text { плетка. }\end{array}$ & $\checkmark$ & $\checkmark$ & $\checkmark$ \\
\hline
\end{tabular}

Табела 15 - Препораки за ходниците во домот МТ. Извор: авторот.

Ходниците во домовите ги поврзуваат станбените единици и заедничкиот простор, но истовремено претставуваат прилика за куса прошетка на станарите како и место за социјализација. За време на посетата во домовите НН и МТ беше забележано како станарите при движењето низ ходникот најчесто застануваат да се поздрават и кратко да проговорат со членовите од персоналот, со другите станари или со посетителите. Во домот VC оваа појава се сретнуваше многу поретко, можеби поради тоа што снимањето се одвиваше на катот со лицата кои се во крајот на вториот и во третиот стадиум на АБ. 
При проектирање на хоризонталните линии на движење низ просторот треба да се земе предвид препораката на Brawley (2006) според која е неопходно да се предвиди зачестување на прошетките на старите лица бидејќи редовното движење ја одржува нивната мобилност. Во снимените домови прошетките најчесто беше предвидено да се одвиваат во надворешните делови на домот (дворот), но во домот VC прошетките беа ограничени во ходниците на катот. Во НН станарите покрај дворот можеа да го користат за прошетки атриумот кој се наоѓаше на приземјето каде има високи прозорци коишто дозволуваат навлегување на големо количество на природна дневна светлина. Меѓутоа она што е специфично за овој дом е тоа што самата распределба на заедничките простории на катот за долготрајна нега, особено положбата на собите за активности и просторот за дневен престој, создаваат еден вид на анимирана прошетка на станарот кога се придвижува од една соба до друга. Во МТ прошетката за лица со АБ би се одвивала главно во краткиот ходник на првиот кат каде што по должината на ходникот, како што е примерот со домот НН, може да се распределат неколку места со активности кои би го наведувале станарот да се движи од едно место до друго. Меѓутоа, покрај раздвижувањето во ходникот станарите со АБ би можеле да бидат изнесени во дворот со придружба на негувател.

\section{ОРИЕНТАЦИЈА И ПРИСТАПНОСТ}

Како што може да се забележи од дијаграмите на слика 33, ходникот во домот НН има форма на буквата $Г$, ходникот во домот МТ има праволиниска форма, а ходникот во домот VC има континуирана форма која на двата краеви завршува со кружно движење. Marquardt и Schmieg (2009) го снимале движењето на станарите низ домови со различни форми на ходници помеѓу кои спаѓаат и горенаведените форми на снимените домови од ова истражување. Според снимените податоци авторите доаѓаат до заклучок дека ориентациската способност на станарите најмногу зависи од големината и формата на ходникот во домот. Следствено на тоа, ходниците со праволиниска форма се најлесни за ориентирање во просторот, додека секоја промена на правецот кај ходниците со посложени форми ја отежнува ориентацијата (Marquardt and Schmieg, 2009). Овој заклучок ја поткрепува формата на ходникот во домот MT но не и онаа на ходникот во VC која според претходно наведеното тврдење делува сложено за станарите. Дополнително на тоа, 
ходникот во VC е долг, што според Marquardt и Schmieg (2009) значи дека ќе има институционален изглед, а според Regnier (2002) дека ќе има монотон и здодевен карактер. Во НН тоа е успешно решено со покривање на подот со теписон, покривање на sидовите со тапети, зидни светилки, цвеќиња, неколку места за седење и означувањето на вратите со лични предмети.

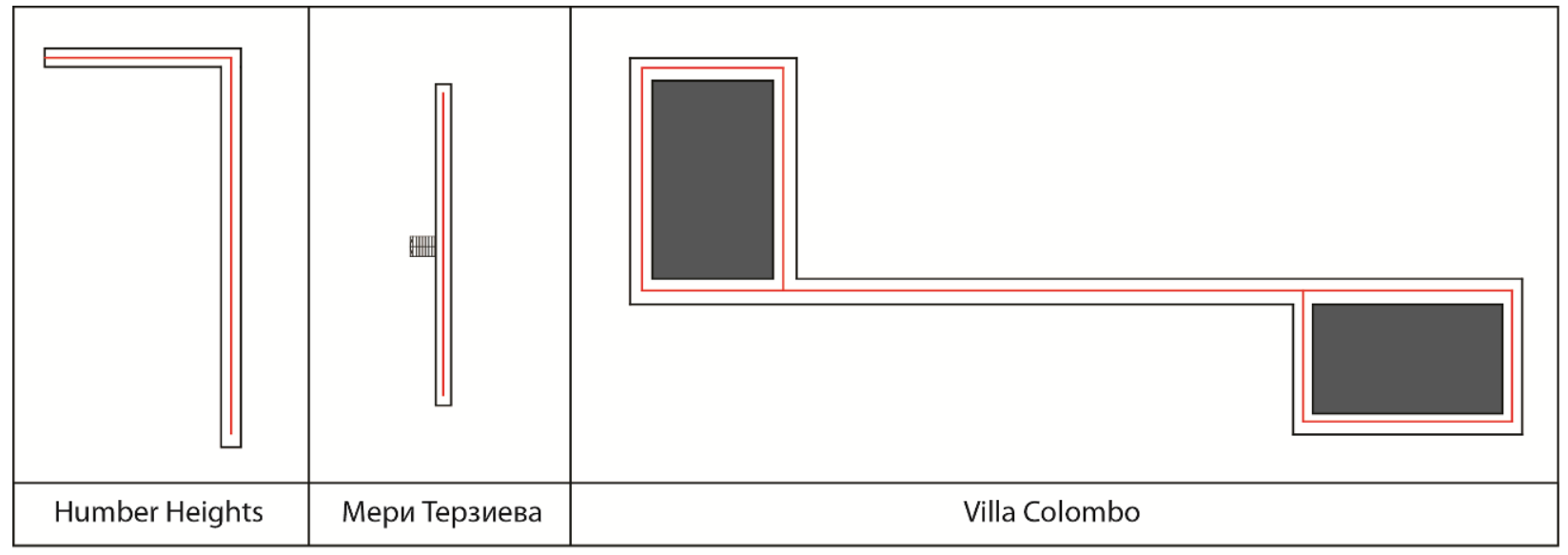

линија на движење низ ходникот

Слика 33 - Дијаграми на формите на ходниците во снимените домови. Извор: авторот.

Покрај нарушувањето на меморијата и когнитивното нарушување, кај лицата со АБ се појавува и загубата на просторната ориентација или визуопросторната меморија (Kavcic et al., 2006; Alescio-Lautier et al., 2007). Уредувањето на ентериер кој ќе произведе добра ориентација не само што помага во задржувањето на самостојноста на станарот, туку и како што забележуваат Marquardt et al. (2011) го намалува товарот од работни обврски кои негувателите ги имаат при постојано надгледување на станарите. Покрај добриот логичен распоред на содржините во ентериерот, просторот од отворен тип дополнително помага во олеснување на надгледувањето на станарите и, според Goodman и Watson (2010) го намалува и времето кое негувателите треба да го поминуваат во секојдневното надминување на растојанието. Движењето на станарите по ходникот особено се олеснува кога крајната дестинацијата е во линија со погледот (Dvorsky \& Pettipas, 2005).

Calkins (2011) наведува неколку забелешки на негуватели кои се однесуваат на талкањето на станарите со деменција низ ходниците во домот, помеѓу кои е истакнато дека при талкањето низ ходниците се случува станарите да се „заглават“ во ходниците кои завршуваат слепо. Иако не беше забележано присуство на станари во близина на слепиот 
крај од ходникот во домот НН како можно избегнување на ваквата појава може да послужи поставувањето на некаков предмет за разонода кој ќе го одвлече вниманието на станарите од преминот на крајот на ходникот. Како што наведуваат Zeisel et al. (2003) забележана е намалена појава на депресија кај станарите кои живеат во безбедна средина и ходници со камуфлиран излез. Што значи дека доколку некоја врата е заклучена за станарите тогаш е пожелно да биде на некој начин прикриена. Utton (2009) посочува пример со поставени маса и стол на крајот од ходникот како начин за криење на слеп крај на ходник. Regnier (2002) пак посочува неколку примери за прикривање на вратите од кои како најуспешен го посочува нивното обложување со тапети идентични со тапетите на околниот sид, а понатаму предложува и боење на вратат во иста боја со зидот или според примерот на студија на случај од дом во Норвешка каде авторот забележал покривање на вратата со завеса од тантела и поставување на саксија од едната страна на вратата.

Wang и Shepley (2008) советуваат дека станарите полесно се ориентираат во покусите ходници со видливи дестинации или јасни ознаки и како пример за тоа го наведуваат заклучокот на Pinet (in Wang and Shepley, 2008) според кој во случај кога растојанието помеѓу станбената единица на станарот и заедничкиот простор е пократко тогаш станарот почесто учествува во друштвени активности. Одовде може да се заклучи дека би било полезно доколку се постави место за седење или изведување на активности во делот во заедничкиот простор кој е видлив од ходникот. На тој начин станарите би биле привлечени кон заедничкиот простор и би земале учество во активност или во акт на социјализација со останатите станари.

Што се однесува до пристапноста на ходникот, во домовите НН и VC тие беа доволно широки за да можат да се разминат две инвалидски колички истовремено, а во сите три домови подот беше на едно ниво што повторно овозможува слободно движење на инвалидска количка како и намалување на веројатноста за препнување и паѓае. Во домот MT ходникот беше значително потесен од останатите домови што го ограничува означувањето на влезовите со лични предмети, но истовремено се одликува со позитивниот аспект на куса должина. 


\section{БЕЗБЕДНОСТ}

Во домот МТ беше забележана една карактеристика на ходникот која многу е веројатно дека ќе предизвика опасност за станарите со АБ. Станува збор за скалите кои се наоѓаат на средишниот дел од ходникот и можат да се забележат на слика 34. Во другите домови скалите се наоѓаa зад безбедносна врата каде што имаше пристап само персоналот. Веројатноста за паѓање по скалите во домот за МТ се намалува со сознанието за постојаното присуство на негуватели и вработени во домот кое беше забележано за време на посетата, меѓутоа веројатноста е сепак присутна.

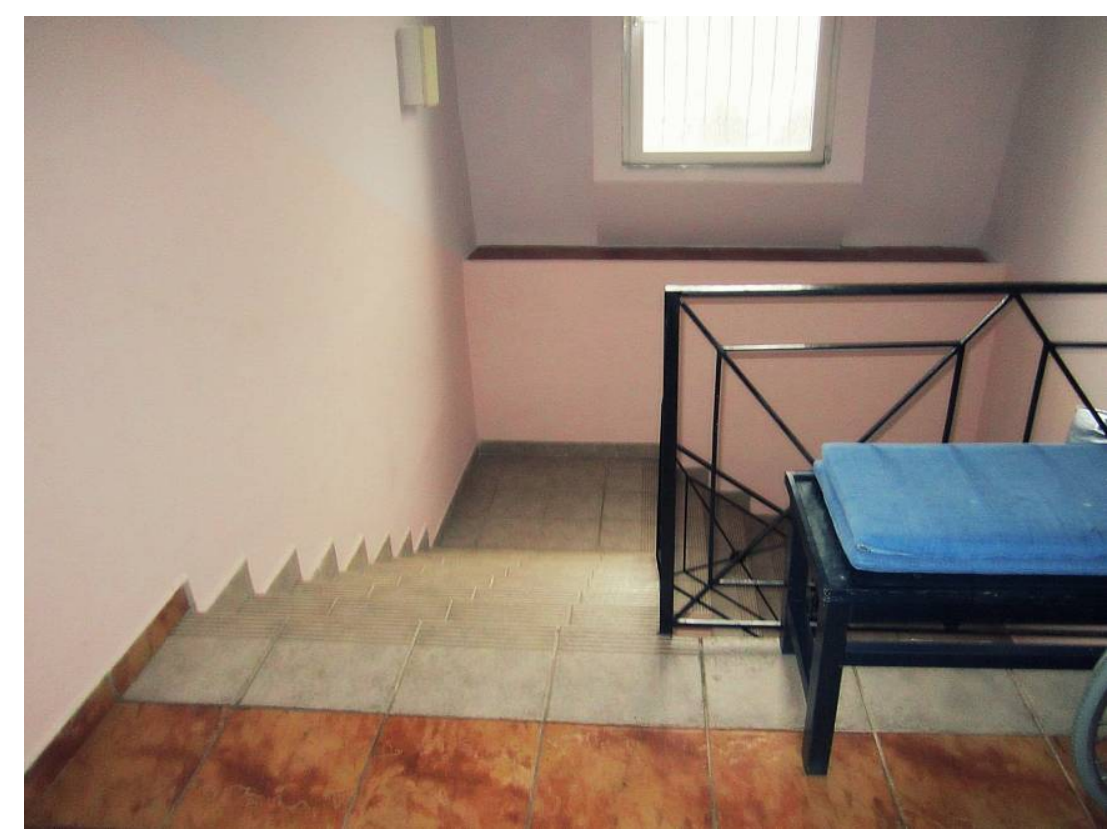

Слика 34 - Скалите во ходникот на домот Мери Терзиева. Извор: од авторот.

Најголем број од смртни случаи и тешки повреди при паѓањето на старите лица се случуваат токму на скалите и тоа најчесто кога лицата се симнуваат во правец надолу по скалите (Templer in Hill et al., 2000). Поголемиот број нарушувања, претходно разгледани во Воведот на стр. 11, кои се појавуваат со развојот на болеста кај лицата со АБ (ослабнат вид, мускулатура, дезориентација, итн.) ја зголемуваат веројатноста за паѓање при движењето низ просторот. Токму поради овие причини, присуството на скали во простор наменет за слободно движење на лицата со АБ треба да се избегне или изолира од употреба. Доколку е неизбежно станарите со АБ да употребуваат скали во домот, тогаш се препорачува газиштето и челото на скалникот да бидат контрастни помеѓу себе и да биде 
поставен ракофат од двете страни на скалите (Joule and Levenson, 2009; Alzheimer's Society, in Churba, 2012). Меѓутоа, кога скалите треба да се употребат во насока надолу и се гледаат одозгора, не е доволно челото на скалникот да биде во контрастна боја со газиштето бидејќи од таа позиција челата не се видливи. Поради тоа, побезбедно е на таа препорака да се додадат сугестијата на Fisk и Raynham (2010) за поставување на светло на врвот и на дното на скалите, како и сугестијата на Joule и Levenson (2009) за употреба на контрастни рабови на скалите што ќе им помогне на лицата со ослабнат вид во забележувањето на крајот на скалилото.

Според Namazi и Johnson (in Davis et al., 2009) поставувањето на ракофати во ходниците овозможува независност во движењето на станарите. Употребата на држачи во просторот е неопходно бидејќи ,jа подобруваат рамнотежата, го охрабруваат движењето и помагаат во надминување на стравот од паѓање“ (Brawley, 2006, p.210). Во домовите НН и VC, како што може да се забележи од Слика 35 и Слика 36, ракофати беа поставени на двете страни на зидовите во ходникот, што соодветствува со сугестијата на Brawley (2006) за неопходноста на истото. Како и сите останати елементи од ентериерот кои треба да бидат забележани од страна на станарите, така и ракофатите треба да бидат во боја контрастна со бојата на позадината т.е. зидот. Што се однесува до видот на ракофатот, Brawley (2006) препорачува употреба на заоблени пошироки држачи, изработени од дрвен материјал поради тоа што делува пријатно и има домашен изглед. Всушност, ракофатите кои Brawley ги препорачува се токму онакви какви што се во ходникот на домот НН прикажани на Слика 35.

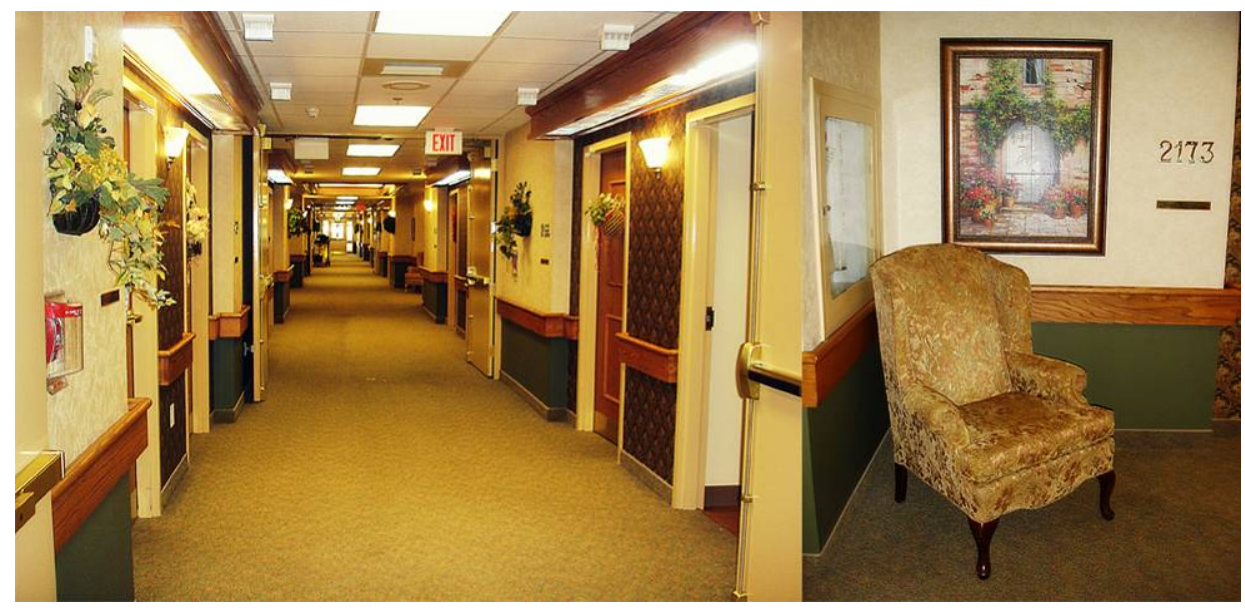

Слика 35 - Ракофати во ходникот на домот НН. Извор: авторот 

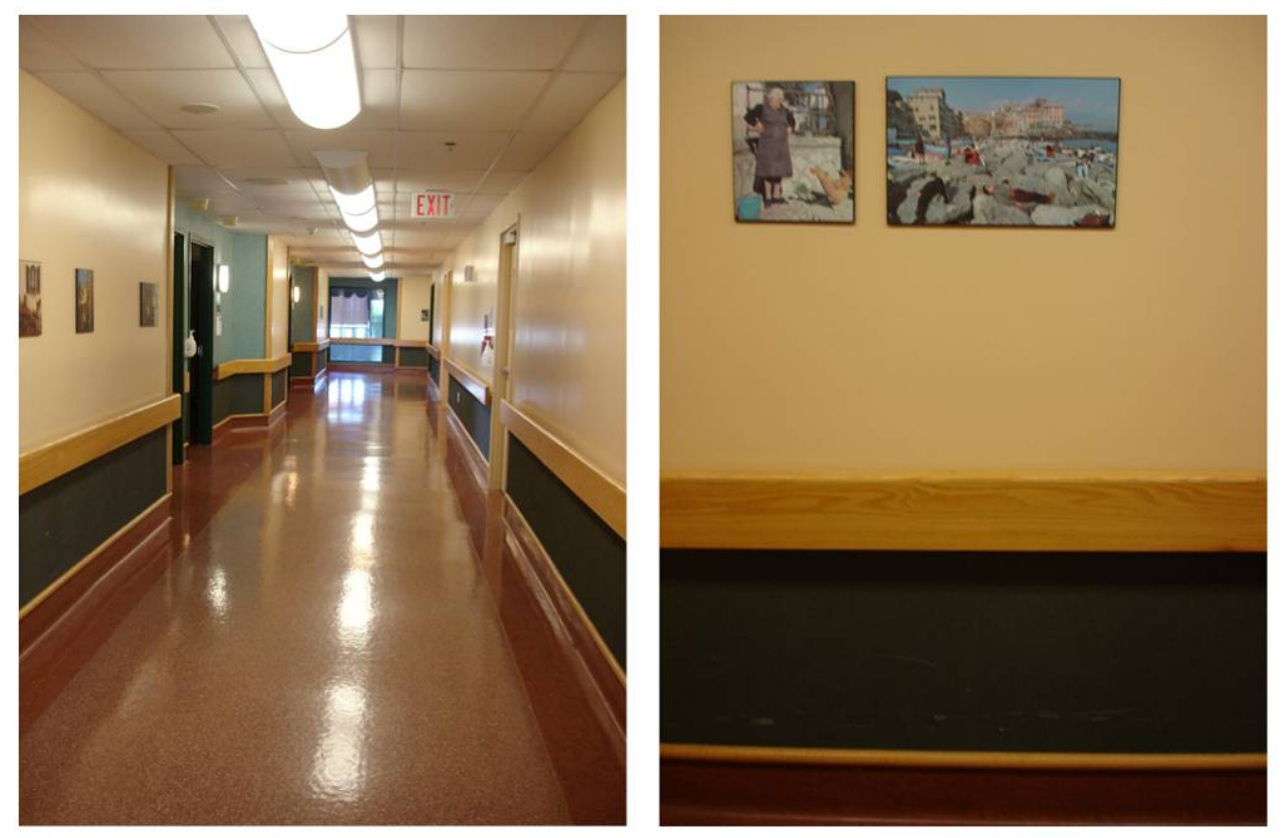

Слика 36 - Ракофати во ходникот на домот VC. Извор: авторот

При посетата на домовите VC и MT беше забележано непријатно осветлување во ходниците. Во VC непријатноста беше главно предизвикана од силниот одблесок на светлината во подната винилна облога со висок сјај. Во МТ беше забележано нерамномерно осветлување поради кое се појавуваа темни предели низ ходникот. Подната облога во ходникот на домот МТ е од керамички плочки кои немаат висок сјај, меѓутоа поради присуството на темни предели на крајот од ходникот од каде влегува светлина од прозорите беше забележан висок отсјај во подот (слика 37).

AКЕ (2010) предлага светлото во ходникот да биде затемнето за време на вечерните часови непосредно пред времето за спиење на станарите, бидејќи како што е понатаму образложено, доколку јачината на светлината остане иста во текот на целиот ден може да ги наруши навиките за спиење на станарите со АБ што би довело до зголемена појава на ноќно талкање. Овој предлог може да се реализира со помошта на инсталирање на потенциометри за контролирање на јачината на светлината низ ходниците или со поставување на дополнително амбиентално осветлување кое ќе остане вклучено навечер откако ќе се изгаси главното светло. 


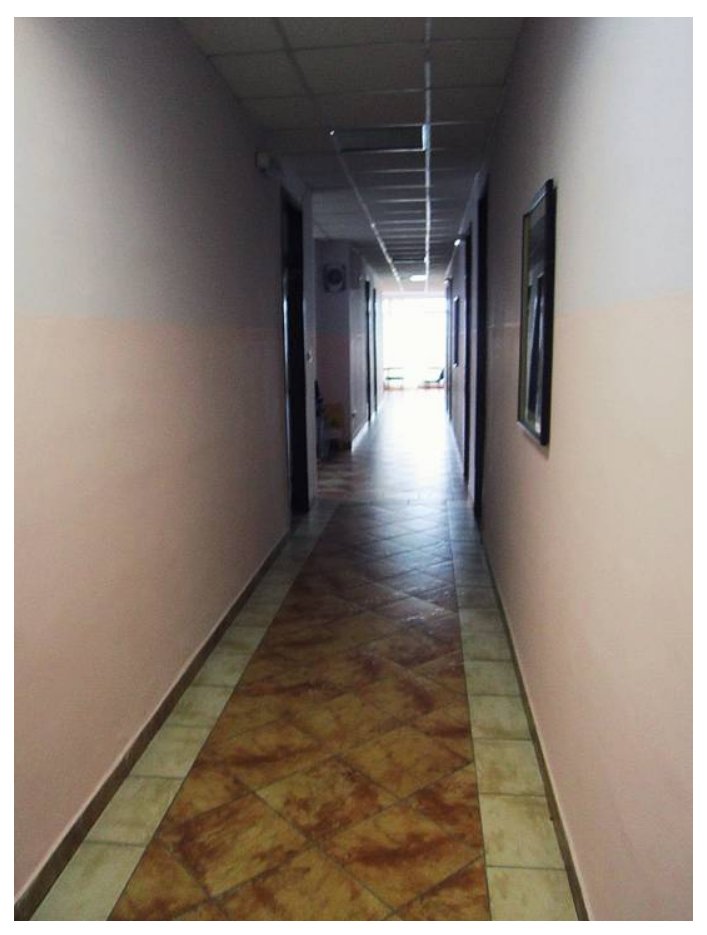

Слика 37 - Присуство на одблесок и темни предели во ходникот на домот МТ. Извор: авторот.

Sидовите во ходникот на Villa Colombo до висина на ракофатот се обоени во темно зелена боја, што создава помалку успешен контраст со бојата на подната облога која е црвена. Успешноста на контрастот би можела да се постигне со употреба на подна облога која не создава одблесок и, според препораката на Brawley (in Tofle et al., 2004, p.49) за создавање на успешен контраст за лица со когнитивни нарушувања, со ,употреба на темни тонови на сина, виолетова и црвена наспроти светли тонови на сино-зелена, зелена, жолта и портокалова“ или поточно боите кои се спротивно поставени на тркалото на боја (Слика 38). Оттука, подобар контраст од темна зелена наспроти темна црвена боја би бил контрастот постигнат со темно црвена и светло зелена, но не и обратно. Brawley опоменува да не се употребуваат посветли тонови од темните бои наспроти потемни тонови од светлите бои при создавање на контраст за лица со когнитивни нарушувања (in Tofle et al., 2004, p.49). 


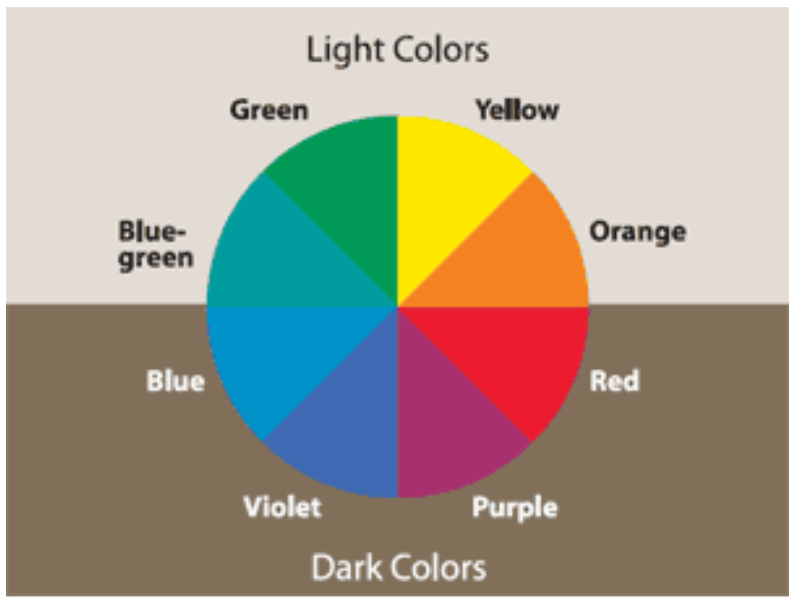

C2005 Lighthouse International. All rights reserved.

Слика 38 - Тркало на боја. Извор: Lighthouse International, (2005), Color wheel [ONLINE]. Available at: http://www.lighthouse.org/images/content/accessibility/color_wheel.gif [Accessed 08 January 13].

\section{Предлози извлечени од прегледаната литература на темата}

\begin{tabular}{|c|}
\hline Ходник \\
\hline $\begin{array}{l}\text { Крајната дестинацијата на ходникот да биде во линија со погледот (Dvorsky \& Pettipas, } \\
\text { 2005). }\end{array}$ \\
\hline $\begin{array}{l}\text { Се препорачува ходниците да имаат праволиниска форма бидејќи се најлесни за } \\
\text { ориентирање во просторот, додека секоја промена на правецот кај ходниците со } \\
\text { посложени форми ја отежнува ориентацијата (Marquardt and Schmieg, 2009) }\end{array}$ \\
\hline Да се ограничи пристапот до скали за лицата со АБ. (Templer in Hill et al., 2000) \\
\hline $\begin{array}{l}\text { Ходникот да содржи забавни карактеристики во вид на уметнички дела или декоративни } \\
\text { елементи (Regnier, 2002). }\end{array}$ \\
\hline $\begin{array}{l}\text { Да се избегнуваат ходници кои завршуваат „слепо“, но доколку постојат да се постави } \\
\text { некаков предмет за разонода кој ќе го одвлече вниманието на станарите од крајот на } \\
\text { ходникот. (Calkins, 2011; Zeisel et al., 2003) }\end{array}$ \\
\hline $\begin{array}{l}\text { Излезите и вратите кои се наменети за употреба од станарите да бидат камуфлирани или } \\
\text { прикриени. (Regnier, 2002) }\end{array}$ \\
\hline
\end{tabular}


Светлото во ходникот да може да се затемни за време на вечерните часови. (АКЕ, 2010)

На крајот од ходниците да се постави место за седење или изведување на активности во делот во заедничкиот простор кој е видлив од ходникот. (Utton, 2009)

Табела 16 - Предлози за ходниците извлечени од прегледаната литература. Извор: авторот.

\subsection{2 Дневна соба}

\begin{tabular}{|c|c|c|c|c|}
\hline & Препорака & H. H. & V.C. & M. T. \\
\hline 1 & $\begin{array}{l}\text { Дневната соба да биде физички одделена од трпезаријата, но } \\
\text { да бидат во близина. }\end{array}$ & $\checkmark$ & $\checkmark$ & $\mathrm{x}$ \\
\hline 2 & $\begin{array}{l}\text { Дневната соба да биде лесно забележителна и сите движења } \\
\text { низ просторот да водат кон неа. }\end{array}$ & $\checkmark$ & $\sqrt{ }$ & $\checkmark$ \\
\hline 3 & Да има чајна кујна во непосредна близина на дневната соба. & $\sqrt{ }$ & $\checkmark$ & $\checkmark$ \\
\hline 4 & Да има тоалети близу до дневната соба. & $\checkmark$ & & $\mathrm{X}$ \\
\hline 5 & $\begin{array}{l}\text { Во седењето на дневната соба да може да се инкорпорираат и } \\
\text { инвалидски колички. }\end{array}$ & $\checkmark$ & $\checkmark$ & $\checkmark$ \\
\hline 6 & Во дневната соба да има присуство на природна светлина. & $\checkmark$ & $\checkmark$ & $\sqrt{ }$ \\
\hline 7 & $\begin{array}{l}\text { Височината на парапетот на прозорите во дневната да не биде } \\
\text { повисок од 600мм. }\end{array}$ & $\checkmark$ & $\checkmark$ & $\mathrm{H} / \Pi$ \\
\hline 8 & $\begin{array}{l}\text { Да бидат достапни ролетни на прозорите за затемнување на } \\
\text { просторот кои ќе го покриваат целиот прозор и станарот ќе } \\
\text { може лесно да ги помести. }\end{array}$ & $\checkmark$ & $\sqrt{ }$ & $\mathrm{x}$ \\
\hline 9 & Да има инсталиран детектор за чад во дневната соба. & $\checkmark$ & $\sqrt{ }$ & $\mathrm{H} / \Pi$ \\
\hline 10 & Да има алармен уред за повик. & $\checkmark$ & $\checkmark$ & $\mathrm{H} / \Pi$ \\
\hline 11 & Штекерите да бидат на височина од 450 до 1200мм од подот. & $\checkmark$ & $\checkmark$ & $\checkmark$ \\
\hline 12 & $\begin{array}{l}\text { Прекинувачите за светло да бидат на височина од } 1000 \text { до } \\
1200 \text { мм од подот. }\end{array}$ & $\checkmark$ & $\checkmark$ & $\checkmark$ \\
\hline 13 & Дневната соба да биде декорирана во светли бои. & $\checkmark$ & $\mathrm{x}$ & $\checkmark$ \\
\hline 14 & Да се избегнува употребата на теписи со крупна плетка. & $\checkmark$ & $\checkmark$ & $\checkmark$ \\
\hline 15 & $\begin{array}{l}\text { Мебелот во дневната соба да има својство на звучна } \\
\text { апсорпција (се мисли на завеси, столици, и др. вид на мека } \\
\text { мебел). }\end{array}$ & $\checkmark$ & $\checkmark$ & $\mathrm{x}$ \\
\hline
\end{tabular}

Табела 17 - Препораки за заедничкиот дневен простор. Извор: авторот. 
Во домот НН просторот за дневен престој беше од отворен тип, без присуство на мидови. Заедничките простори од отворен тип според Utton (2009, р.386) се важни за „дискретното надгледување на станарите кои се наоѓаат во тој простор“ од страна на негувателите во домот. Utton понатаму образложува дека во случајот кога заедничките простори се физички издвоени и затворени, потребна е поголема ангажираност на персоналот за да ги надгледува станарите во секој простор поединечно. Покрај заедничките простори од отворен тип, во НН беше забележана и можноста да се надгледува внатре во сите затворените простории за заедничка употреба преку отвор во sидот во вид на прозорец. Regnier и Denton $(2009$, p.180) посочуваат на значајноста на овој начин на прегледност за самите станари со АБ, бидејќи тие поради когнитивните нарушувања „најчесто не се во можност да замислат ито има од другата страна на sидовите“ и истото би можело „да ги мотивира да земат учество во активности“ кои се одвиваат во просториите. Просторот за дневен престој во домот НН беше соодветно ситуиран на крајот од двата ходници кои водеа кон заедничките простории, како и помеѓу просторот за хранење и семејната кујна (Слика 39).

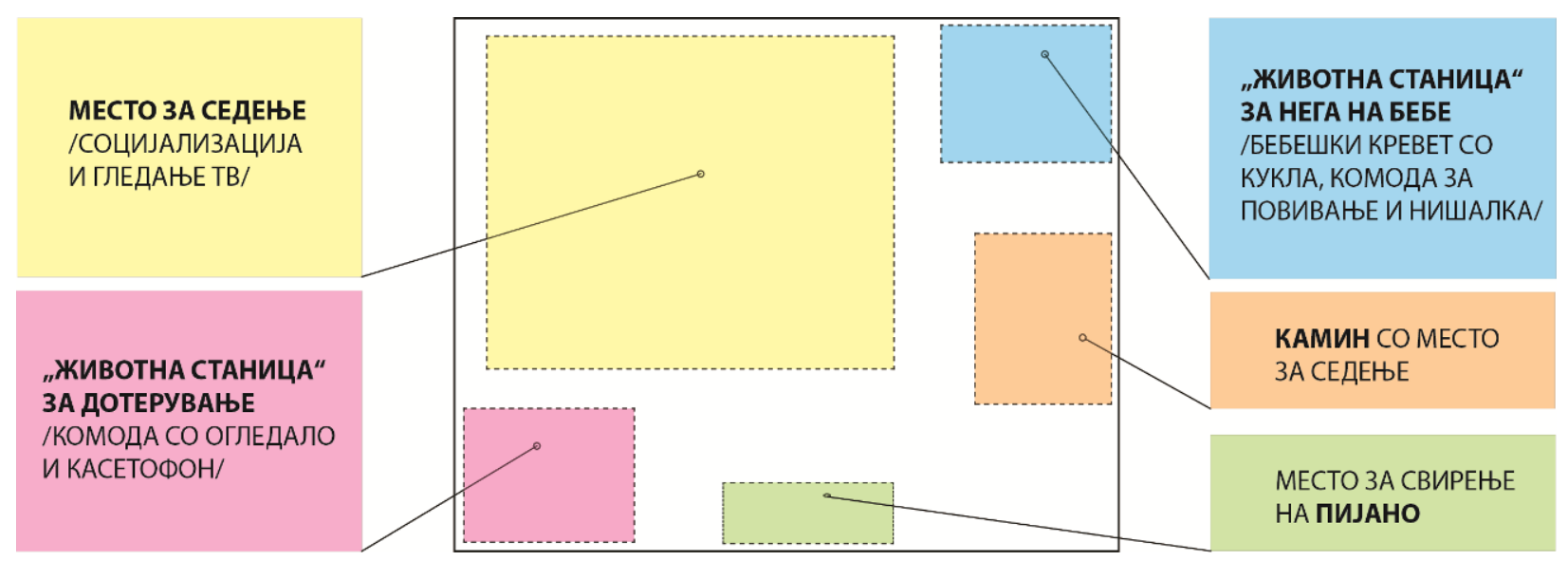

Слика 39 - Шематски приказ на содржините во просторот за дневен престој во домот НН. Извор: авторот.

Распоредот на дневниот простор во НН е шематски прикажан на Слика 39. Вклучени во просторот за дневен престој во домот НН беа следните содржини: 
1. Таканаречена „станица за животни вештини“ за дотерување на станарите од женскиот пол која се состоеше од комода со огледало, музички систем и место за седење. Како што може да се забележи од фотографијата (Слика 40) во ова катче беше закачен невестински фустан чијшто цел веројатно беше да ги потсети станарките на времето од нивната младост.

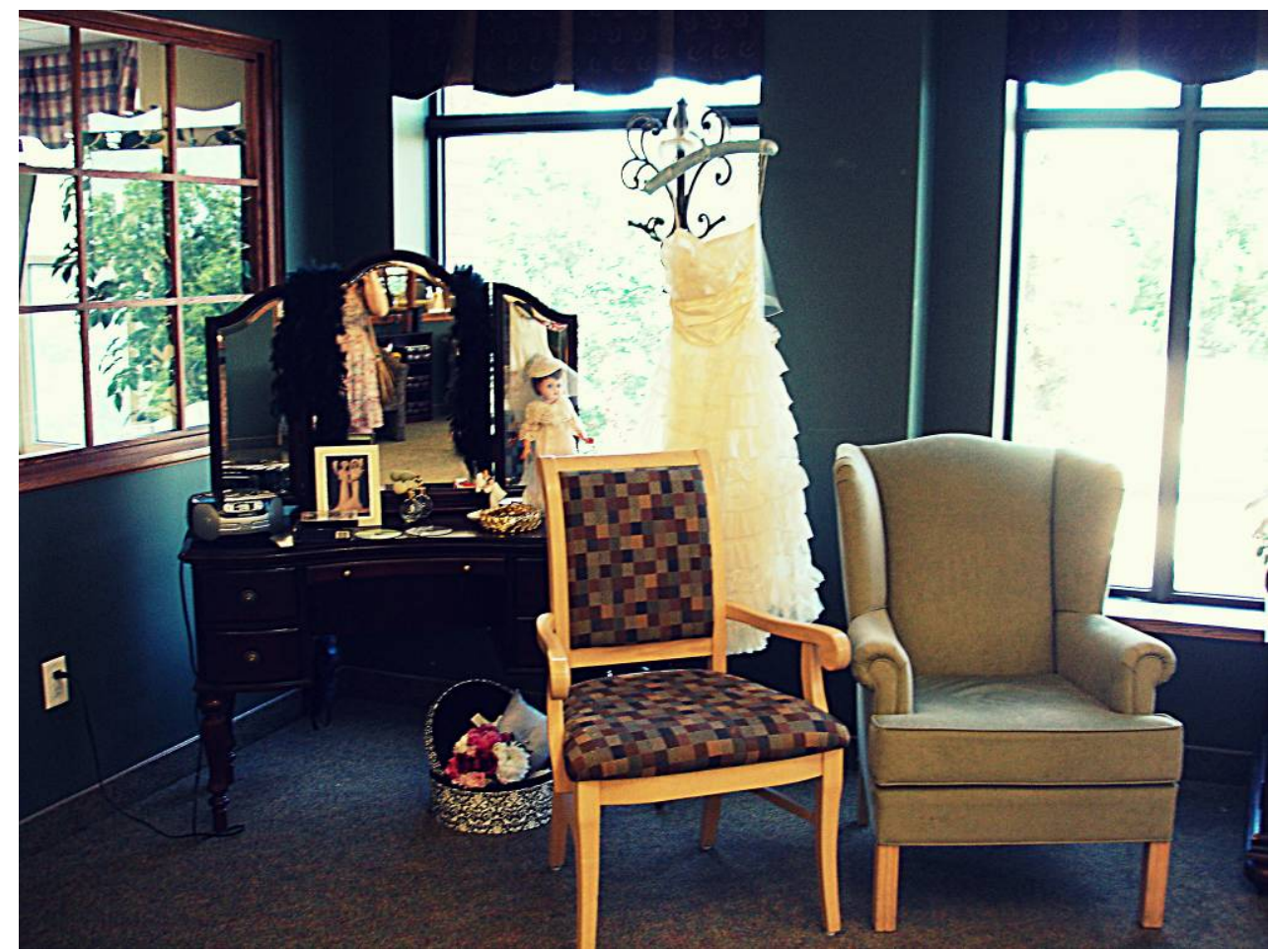

Слика 40 - „Станица за животни вештини“ за дотерување во дневниот простор на домот НН. Извор: авторот.

2. Место за седење и социјализирање или гледање на ТВ програми (Слика 41) кое се состои од мек мебел групиран заедно и насочен кон ТВ уредот, како и еден двосед насочен во обратниот правец и едно додатно место за седење на фотелји покрај прозорците со мала библиотека. Според распоредот на мебелот во дневната соба во НH прикажан на слика 41, може да се забележат повеќе групи на седење за различен број на станари, што го зголемува изборот на станарот да се вклучи кон одредена група. Dvorsky и Pettipas (2005) се сложуваат дека распоредот на мебелот има значајна улога во создавањето на услови за социјализација помеѓу станарите, 
при што сепак треба да се обрне внимание на задржувањето на самостојноста на станарот.

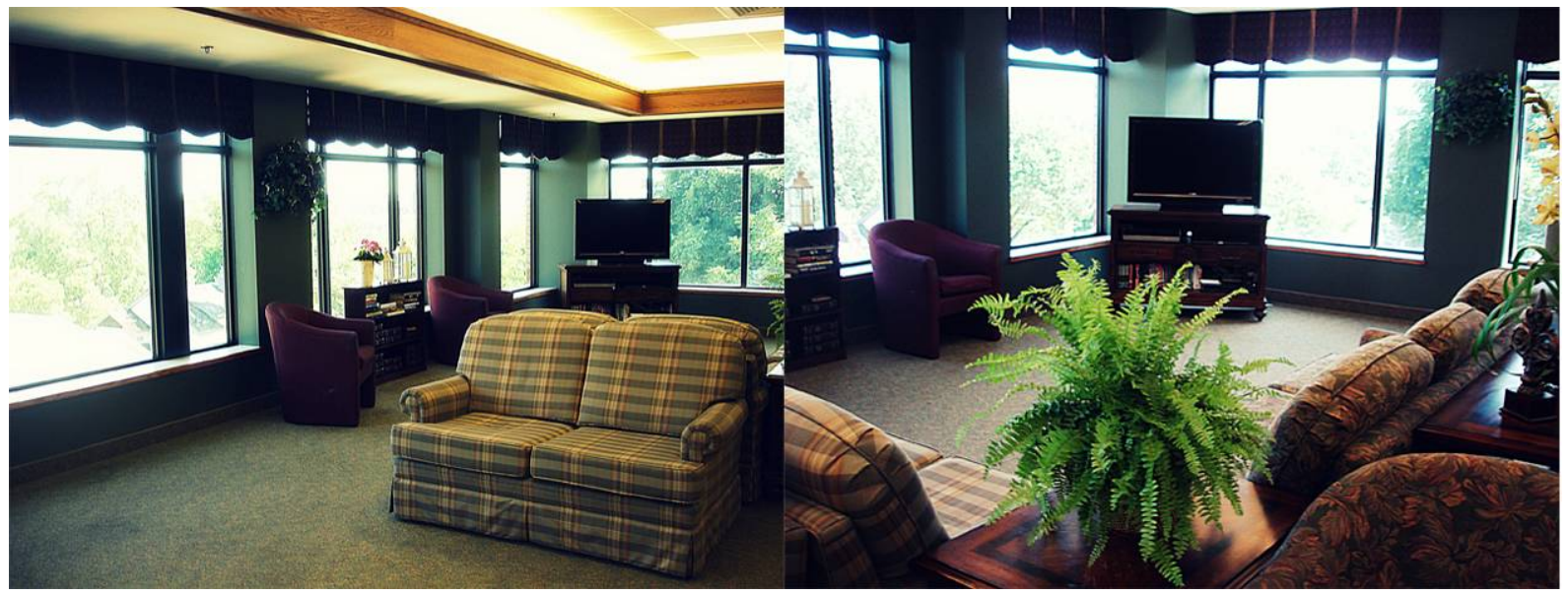

Слика 41 - Поглед кон местото за седење покрај ТВ уредот во просторот за дневен престој во НН. Извор: авторот.

3. „Станица за животни вештини“ за нега на бебе (Слика 42), што во овој случај всушност е кукла која станарите можат да ја превиваат на комодата за повивање, да ја легнуваат во креветчето или да ја држат во своите раце додека седат на столот. Во едно истражување спроведено од страна на Tamura et al. (2001) куклите биле употребувани во дом за стари лица како терапевтско средство за лицата со деменција, при што авторите забележале дека станарите од двата пола се однесувале грижливо кон нив и ги направило општо посреќни. Врз основа на однесувањето на станарите околу куклите, авторите заклучиле дека овој вид на терапија е успешно дополнително помагало во негата за лица со деменција. Оттука, примената на ваков вид на „животна станица“ за нега на бебе може да се очекува дека ќе ги разбуди мајчинските инстинкти кај станарките, но воедно и да предизвика нежност кај станарите од машкиот пол. 


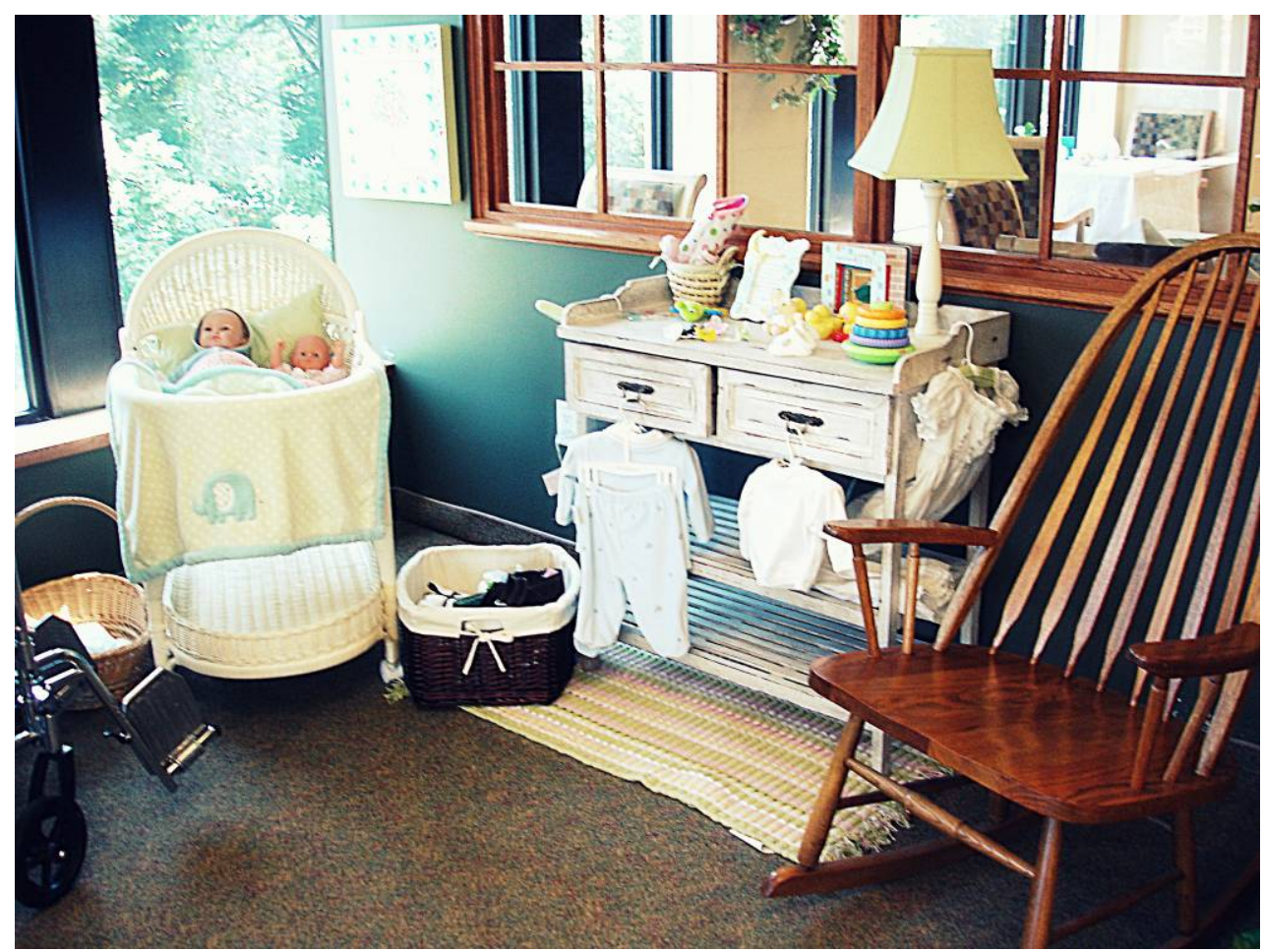

Слика 42 - „Станица за животни вештини“ за нега на бебе во дневната соба на домот НН. Извор: авторот.

4. Место со мала библиотека за читање покрај камин (Слика 43). Како што истакнува Brawley (2006) присуството на камин создава пријатна атмосфера во просторот каде што се собираат станарите. Дури и да се работи за електричен камин, доколку му се даде традиционален изглед, по примерот на каминот во $\mathrm{HH}$, тој сепак ќе придонесе во креирањето на домашна атмосфера во просторот.
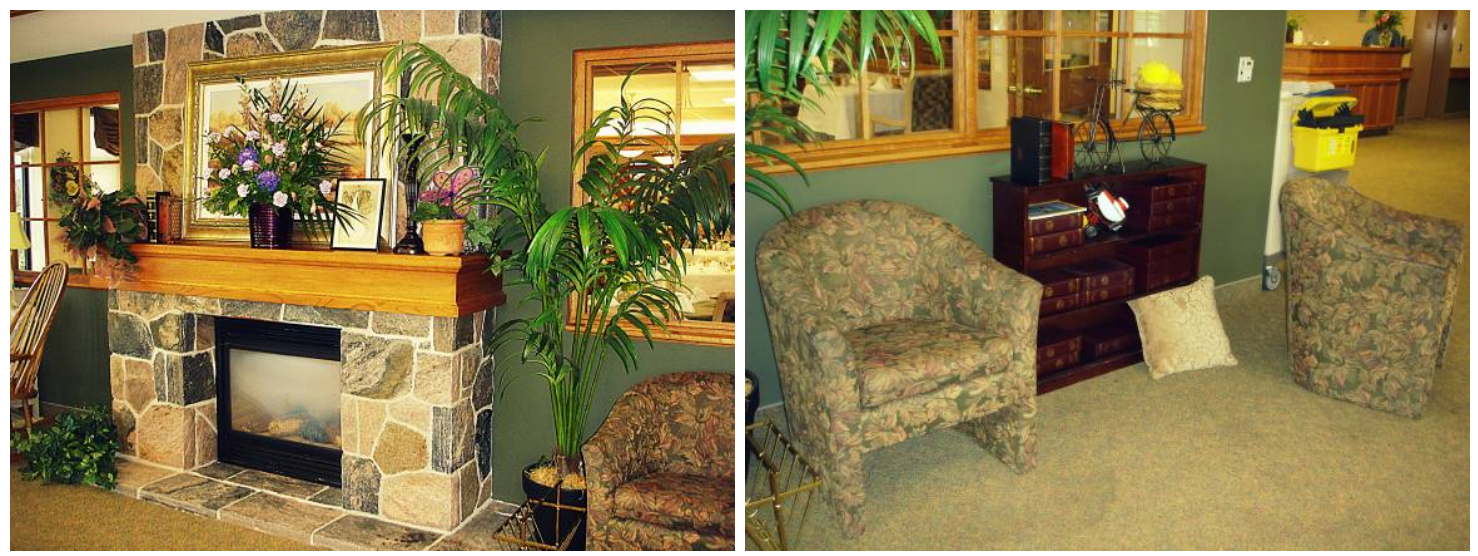

Слика 43 - Поглед кон каминот во дневниот простор на домот НН и местото за седење до каминот. Извор: авторот. 
5. Место за свирење на пијано, помеѓу просторот за дневен престој и семејната кујна (Слика 44). Според менаџерот на домот HН (D.W., personal communication, August 12, 2011), покрај станарите пијаното е употребувано и од професионални музичари или од членови на семејството на некој од станарите коишто доброволно се пријавуваат да свират за време на некој од вообичаените настаните кои се одржуваат во овој простор. Simmons-Stern, Budson и Ally (2010) при истражувањето на влијанието на музиката врз лицата со АБ откриле дека таа ги возбудува и релативно ги подобрува вниманието и меморијата. Од овие причини, присуството на музика и музички инструмент во домот за лица со АБ може да игра значајна улога во терапијата на овие лица.

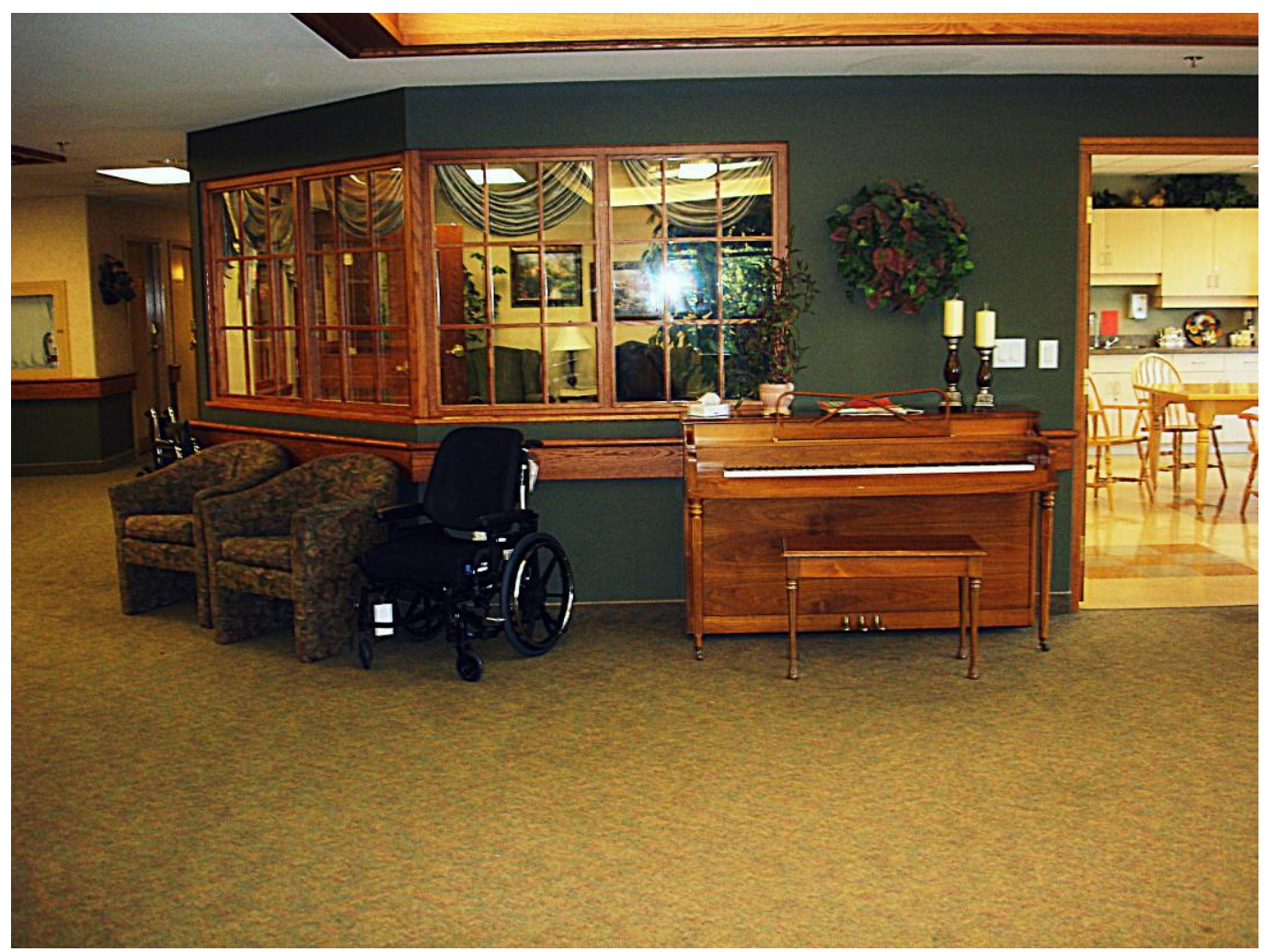

Слика 44 - Поглед кон пијаното поставено помеѓу дневниот простор и семејната кујна во домот нН. Извор: авторот.

Дневниот простор во домот НH заедно со дополнителните заеднички содржини и „станиците за животни вештини“ ја задоволуваат препораката на Regnier и Denton (2009) според која заедничките содржини во домот треба да бидат разновидни и уникатни со што ќe му овозможат слободен избор на станарот за местото каде што ќе одбере да го помине 
своето време. Разновидноста на дневниот простор беше помалку застапена во другите два домови.

Спротивно на примерот од домот НH, просторот за дневен престој во домовите МТ и VC претставуваше физички затворена просторија со сопствен влез, со тоа што во домот VC сепак имаше прегледност во просторијата поради стаклената влезна врата и стаклениот отвор во вид на прозорец кој може да се види на Слика 45. Во дневната соба во домот VC мебелот изгледаше случајно поставен, не беше забележано присуство на декоративни елементи и имаше само еден вид на осветлување - плафонското. Сето тоа ја правеше собата да изгледа студено и институционално. Ниските парапети на прозорците овозможуваа присуство на поголема количина на светлина во текот на денот, како и пријатен поглед кон небото и дрвјата.

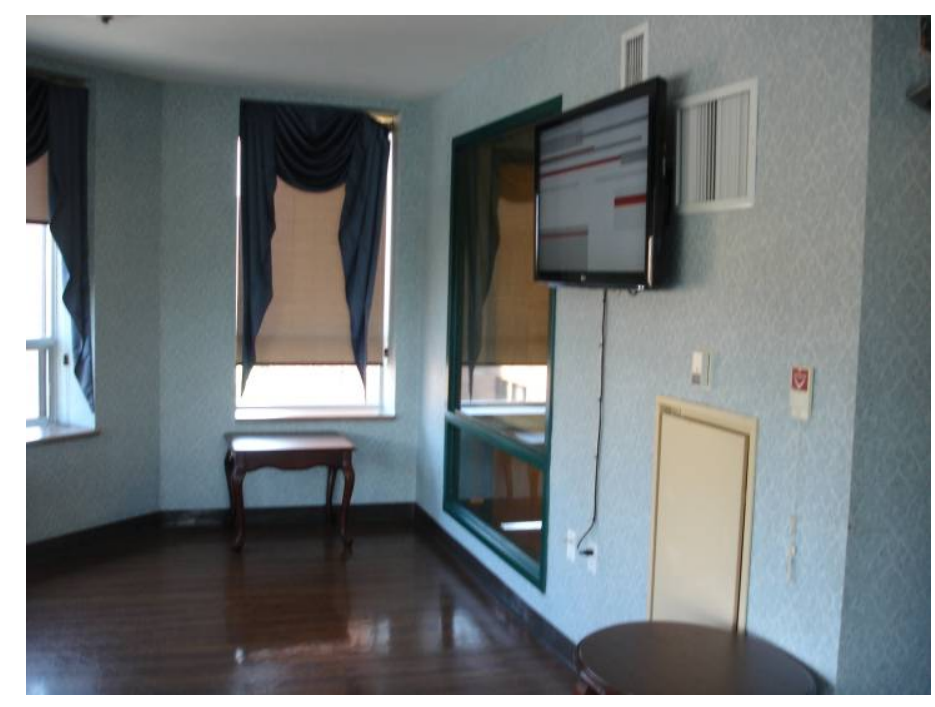

Слика 45 - Дневната соба во домот VC. Извор: авторот.

Kane и Cutler тврдат дека станарите и нивните блиски повеќе сакаат да бидат во приватните станбени единици отколку да поминуваат време во заедничките простории. Ова треба да се земе како предизвик од страна на дизајнерите и да ги натера да бидат упорни во својот обид за привлекување на станарите во заедничките простории и поттикнување на социјални интеракции помеѓу станарите. 


\section{Предлози извлечени од прегледаната литература на темата}

\begin{tabular}{|c|}
\hline Дне \\
\hline $\begin{array}{l}\text { Распоредот на мебелот да асоцира на неговата употреба со што ќе го привлече станарот } \\
\text { (Regnier, 2002). }\end{array}$ \\
\hline $\begin{array}{l}\text { Распоредот на мебелот да создаде услови за интеракција помеѓу станарите (Dvorsky \& } \\
\text { Pettipas, 2005). }\end{array}$ \\
\hline $\begin{array}{l}\text { Присуството на камин создава пријатна атмосфера во просторот и станарите сакаат да } \\
\text { седат околу него (Brawley, 2006). }\end{array}$ \\
\hline $\begin{array}{l}\text { Присуството на музика и музички инструмент во домот за лица со АБ ги возбудува } \\
\text { станарите со АБ и релативно ги подобрува вниманието и меморијата (Simmons-Stern, } \\
\text { Budson \& Ally, 2010). }\end{array}$ \\
\hline $\begin{array}{l}\text { Заедничките содржини во домот пожелно е да бидат разновидни и уникатни со што ке му } \\
\text { овозможат слободен избор на станарот за местото каде што ќе одбере да го помине своето } \\
\text { време (Regnier \& Denton (2009) }\end{array}$ \\
\hline
\end{tabular}

Табела 18 - Предлози за заедничката дневна соба извлечени од прегледаната литература. Извор: авторот. 


\section{6. Сугестии за можни модификации на простори во домот Мери Терзиева за потребите на лица со Алцхајмерова Болест}

Во ова истражување ќе бидат предложени сугестии за модификација кои ќе се однесуваат главно за станбените единици во домовите. Врз основа на извлечените поуки од разгледувањето на домовите во Поглавје 5 , овде ќе бидат изработени модификации со минимален градежен зафат и модификации со поголем градежен зафат.

\section{1 Сугестии за можна модификација на простори во домот Мери Терзиева за потребите на лицата со Алцхајмерова Болест со минимален градежен зафат}

Сугестиите за модификација на домот МТ со минимален градежен зафат главно се однесуваат на додавање или одземање на лесно подвижни елементи од ентериерот, како и на декоративните аспекти на ентериерот во домот. Сугестиите коишто се наведени овде не вклучуваат градежни промени од поголем карактер и оваа одлика ги прави полесни за изведување.

\subsection{1 Станбена единица}

Постојната состојба на станбените единици во МТ ја ограничува соодветната организација на просторот со оглед дека станува збор за соби на поткровје кои немаат соодветна висина. Поради тоа, просторот не дозволува преместување на креветот во повеќе позиции и тој може да биде поставен исклучиво во двете ниши покрај прозорецот. Ова може да биде полезно во случај кога лицата со деменција имаат проблеми со паѓање од кревет и тогаш најдобро е едната од подолгите страна од креветот да биде потпрена на мидот за да се спречи тоа (deLaski-Smith, 1998). За другата страна од креветот deLaski-Smith (1998) вели дека треба да има слободен простор од 90см за пристап од негувател или за трансфер на станарот од инвалидска количка во кревет, што не може да се постигне во ниту една варијанта за модификација на станбената единица со помал градежен зафат.

Ограничувања во распоредот на станбената единица се забележува и во тоалетот каде што не може да се примени основното и најчесто повторувано правило за проектирање на пристапни тоалети според кое треба да се обезбеди слободен простор со дијаметар од 
1500мм за завртување на инвалидска количка. Поради сите горенаведени причини, сугестиите за модификација на станбената единица во МТ нема да ги содржат сите основни правила за непречен пристап, но ќе содржат подобрувања кои има можност да се реализираат во постојниот простор. Со изведување на предложените сугестии ќе се создадат подобри услови за сместување на лице со АБ во станбена единица прилагодена за потребите на лицата со АБ.

Во сугестиите за можна модификација на простори во домот МТ со минимален градежен зафат се изработени три варијанти на распоред во станбената единица кои помалку или повеќе се разликуваат меѓусебно. Постојната состојба на снимената станбена единица како и трите можни варијанти на адаптација на единицата се прикажани на Слика 46. Секоја варијанта може да се комбинира со одредени атрибути на некоја од другите варијанти. Заедничка промена во сите три варијанти е отстранувањето на вториот кревет со цел станбените единици да бидат еднокреветни. Причините за оваа одлука се следните:

1. Како што беше наведено во Методолошкиот пристап, оваа студија главно се базира на создавање на услови за престој во дом за лица со АБ кои се наоѓаат во првиот и вториот стадиум на болеста. Нивната потреба за повремена изолација од останатите станари и персоналот во почетните стадиуми е неизбежна, поради што би било добро во својата станбена единица да имаат катче за седење каде што ќе можат да поминат дел од своето време.

2. Присутноста на два кревети едновремено во станбената единица со мали димензии го ограничува слободното движење низ единицата за лицата со инвалидска количка. Како што може да се забележи во основата на постојната состојба на Слика 46 во просторот помеѓу двата кревети нема 1500мм за слободно завртување на инвалидска количка. Покрај пристапот со инвалидска количка, во постојниот простор негувателите ви имале потешкотии во управувањето со подвижна дигалка и друг вид на медицински помагала. 
Сугестии за можна модификација на просторот во домот Мери Терзиева за потребите на лицата со Алцхајмерива Болест со минимален градежен зафат

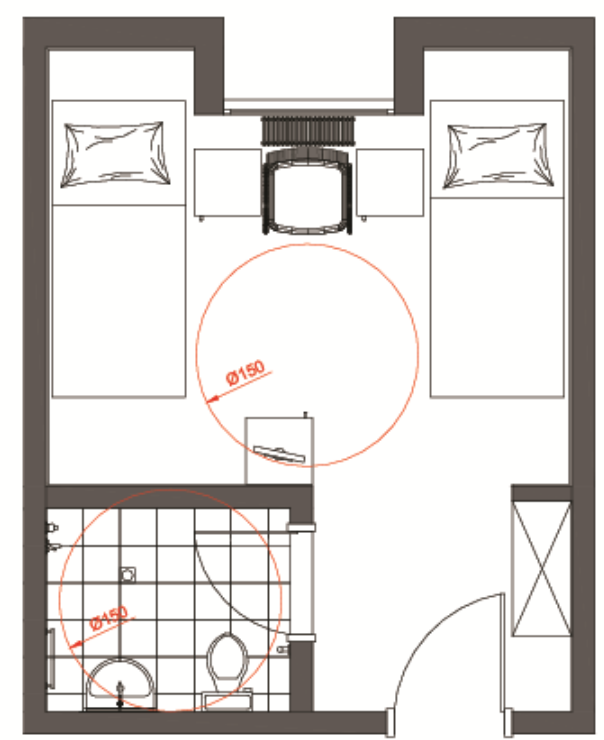

постојна состојба

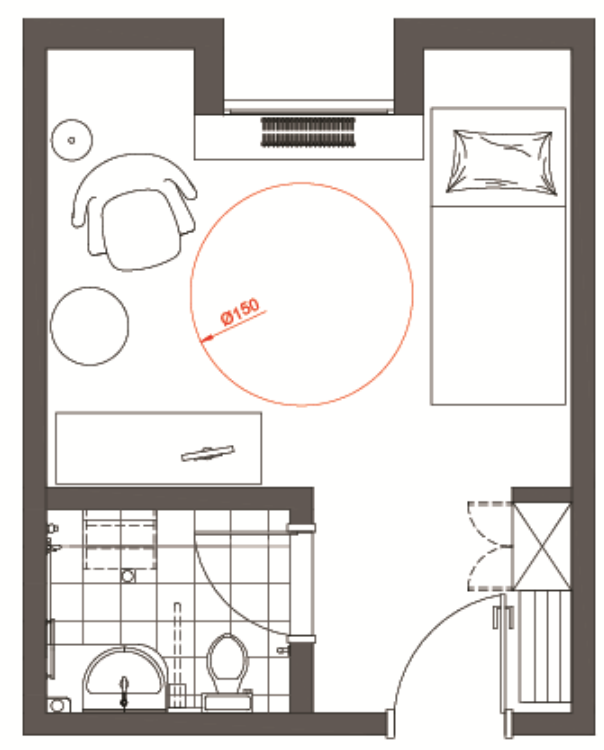

варијанта 2

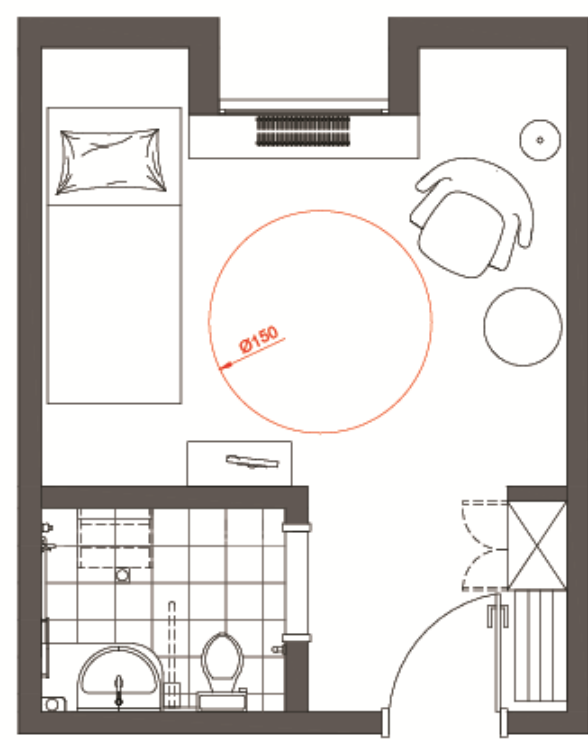

варијанта 1

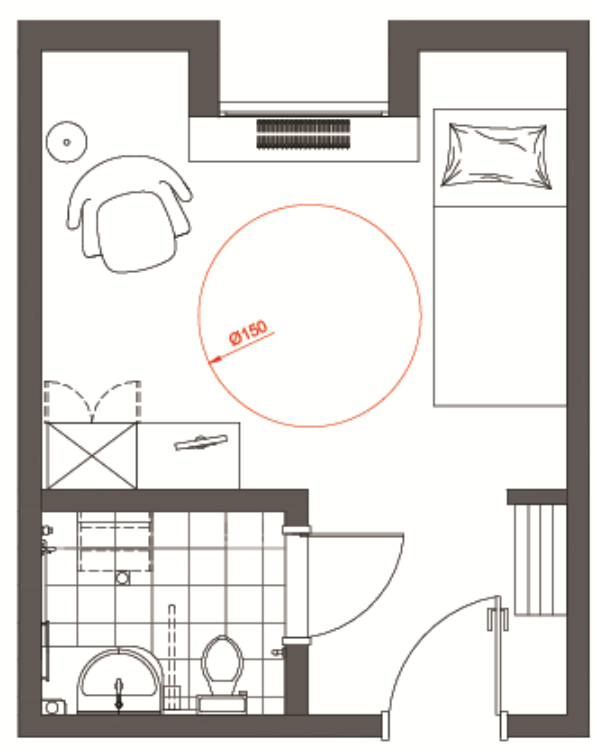

варијанта 3

Слика 46 - Сугестии за можна модификација на простори во домот МТ со минимален градежен зафат изразени преку три варијанти. Извор: авторот. 


\section{Опис на варијантите на сугестии за можна модификација на простори во домот МТ со минимален градежен зафат}

\section{Сугестии за можна модификација на претсобјето во станбените единици}

Влезната врата во постојната состојба на станбената единица се отвора за помалку од 90 степени поради плакарот кој се наоѓа зад вратата, со што тоа се намалува пристапноста во станбената единица. На Слика 47 е прикажана постојната состојба на плакарот во претсобјето и веднаш до него сугестијата за новиот плакар. На сликата може да се забележи дека отворањето на вратата од плакарот може да претставува пречка за отворањето на влезната врата, и обратно. За да се надмине овој проблем треба да се преземат мерки за поместување на плакарот на друго место во собата или заменување на постојниот со нов плакар кој ќе има помали димензии и ќе го собере во просторот може отворена влезна врата и преградниот sид. За втората опција би се изработил плакар по мерка, со поадекватни димензии - широчина 60см, длабочина 50 см и вкупна височина од околу 160-180см. Важно е височината на плакарот да соодветствува со висината на дофат за стари лица којашто е околу 160см (RIBA, 2011) или висината на дофат за лица во инвалидска количка - најмногу 137см (City of Toronto, 2004).

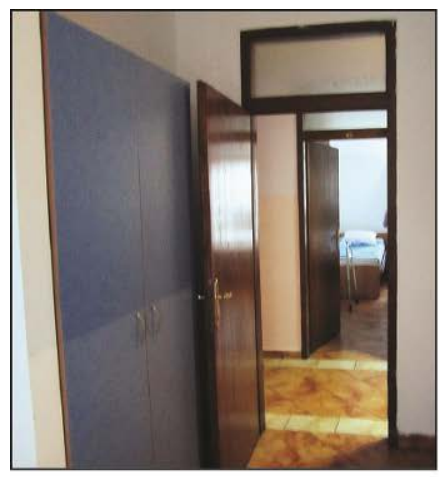

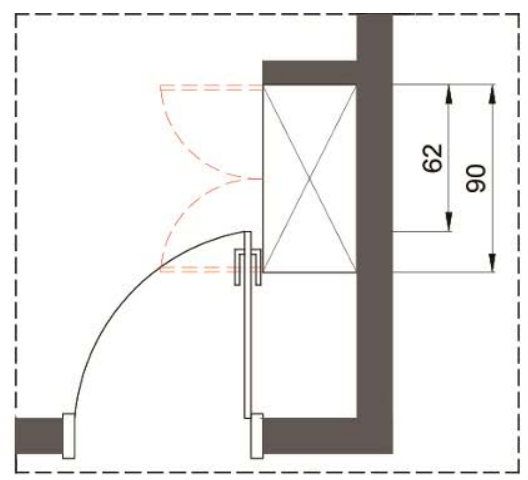

ПОСТОЈНА СОСТОЈБА

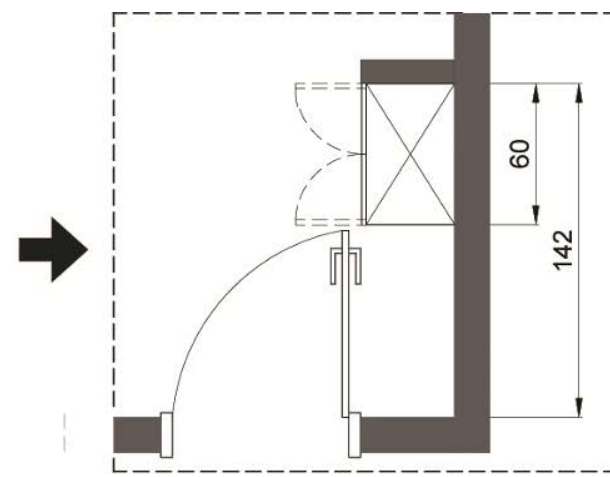

СУГЕСТИЈА

Слика 47 - Фотографија и скица на постојна состојба на плакарот во претсобјето и сугестија за нов плакар. Извор: авторот.

На Слика 48 е прикажан предлог за изгледот на внатрешноста на плакарот кој поради помалата длабочина ќе има потреба од фронтално поставување на закачалките како што и во предлогот на сликата. Начинот на поставување на закачалките прикажан на Слика 48, може да им помогне на станарите во облекувањето со тоа што на првата закачалка 
негувателите или член од семејството може да ја закачат облеката којашто станарот треба да ја носи следниот ден. Тоа веројатно би помогнало станарот да се облекува соодветно со временските услови.

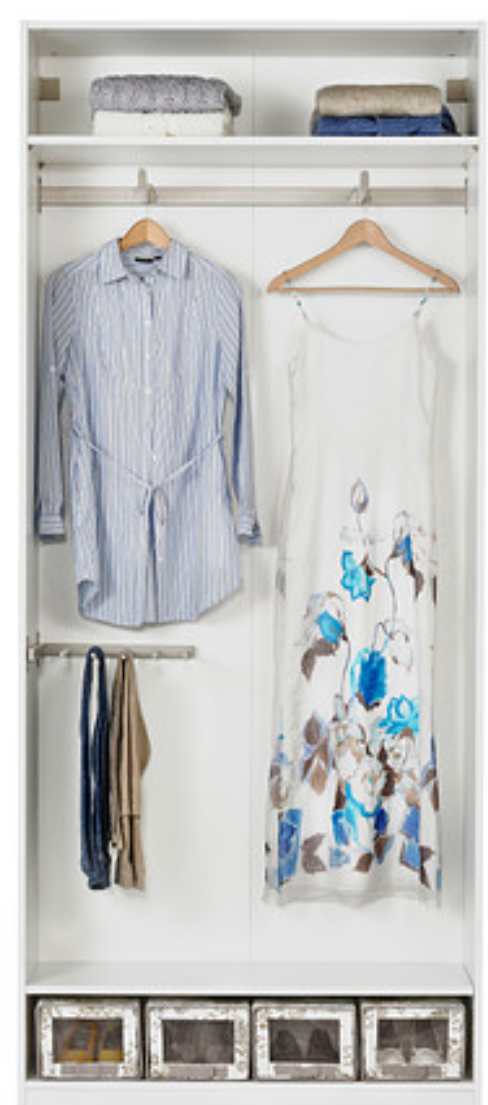

Слика 48 - Предлог за изгледот на внатрешноста на плакар со помали димензии изработен по мерка.

Извор: IKEA, (2013), PAX Wardrobe with interior organizers [ONLINE]. Available at:

http://www.ikea.com/us/en/catalog/products/S59932735/ [Accessed 17 May 13].

Истовремено овде може да се примени препораката на Regnier (2002) за употреба на складишен простор со стаклени врати со цел станарот полесно да ги наоѓа своите предмети. Доколку се постави плакар со помала широчина, тогаш во просторот зад вратата ќе може да се постават закачалки (Слика 49) па дури и тесна клупа за оставање на чевли (Слика 50). Исто, ако еднособната станбена единица во домот се промени од двокреветна во еднокреветна, тогаш просторот ќе дозволи да се смести дополнителен складишен простор во вид на орман или креденец со фиоки и на станарот нема да му биде 
скратен складишниот простор со поставувањето на плакар со помала широчина од сегашниот.

Во Варијанта 1 и Варијанта 2 е отстранет постојниот плакар и е заменет со плакар изработен по гореспоменатата мерка. Во слободниот простор што ќе се добие зад вратата во двете варијанти додадени се закачалка за палта и шапки, како и клупа за оставање на чевли која би помогнала во поставување на чевлите на дофат за станарот без потребата од наведнување до подот. Како предлог за изгледот и видот на закачалката и клупата може да послужат Слика 49 и Слика 50.

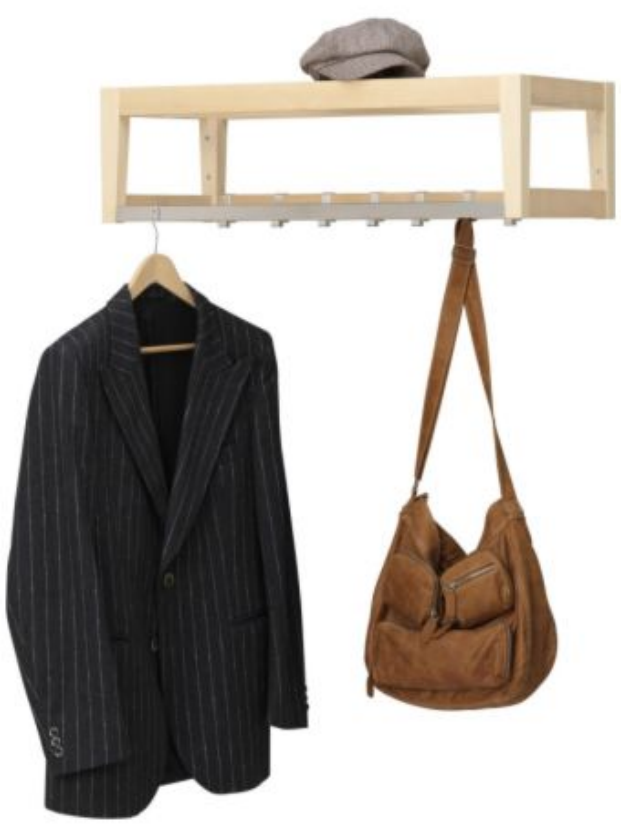

Слика 49 - Пример за закачалка/полица која би можела да се постави зад вратата во Варијанта 1 и 2. Извор: IKEA, (2013), STÄLL Hat rack, birch, stainless steel [ONLINE]. Available at: http://www.ikea.com/us/en/catalog/produhttp://www.harvardgenerator.com/references/onlineimagects/S59932735/ [Accessed 17 May 13]. 


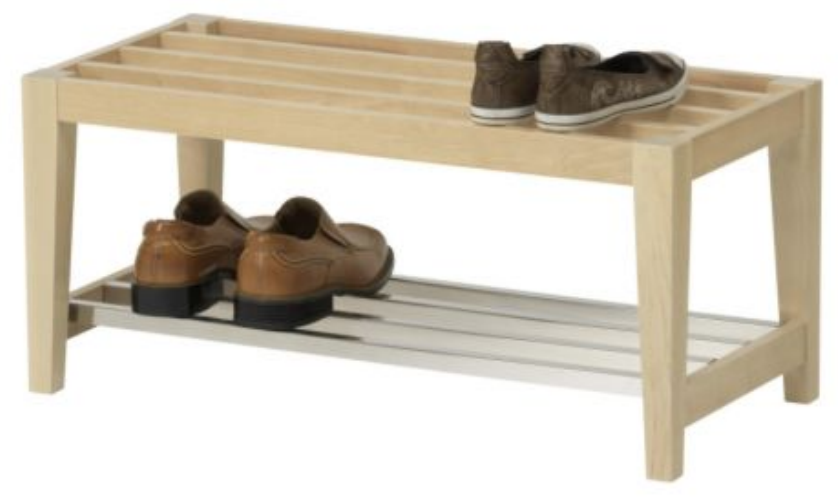

Слика 50 - Пример за клупа за чевли која би можела да се постави зад вратата во Варијанта 1 и 2. Извор: IKEA, (2013), STÄLL Shoe rack [ONLINE]. Available at: http://www.ikea.com/us/en/catalog/products/20152667/ [Accessed 17 May 13].

\section{Сугестии за можна модификација на просторот за спиење и дневен престој во станбените единици}

Просторот за спиење и дневен престој во Варијанта 1 се состои од поставување на кревет на левата страна од станбената единица и место за седење од другата страна. Овој начин на поставување на креветот има некои предности како што има и одредени недостатоци. Имено, со наведената промена ослободена е линијата на движење од влезот кон просторот за спиење и дневен престој од можни пречки кои би ги создал аголот на креветот поставен од десната страна на станбената единица во Варијанта 2 и 3. Со промената би се овозможил непречен пристап за лица со мобилни помагала, но и за внесување на подвижни дигалки и медицинска опрема во просторот. Меѓутоа, со поместувањето на креветот на левата страна во Варијанта 1 се губи погледот кон тоалетот кој станарот би го имал во Варијанта 2 и 3 и што во Поглавје 5 (стр. 50) заклучивме дека е значајна особина на станбените единици за лица со пречки во помнењето. Исто така, до одреден степен го зголемува работниот процес при проверките на станарот од страна на персоналот при што негувателот не би можел да ги провери станарите само со отворање на влезната врата. Во 
варијанта 2 и 3 како што веќе беше споменато, позицијата на креветот е на десната страна од станбената единица со што слободниот простор помеѓу аголот на креветот и аголот на sидот се намалува на $100 \mathrm{~cm}$. Како помошно средство за Варијанта 1 кога креветот нема поглед кон тоалетот, меѓутоа би било полезно и за другите варијанти, може да се постави суптилно жолтеникаво LED осветлување во вид на ленти кое ќе ги означува пределите кои станарот треба да ги користи или одмине во ноќните часови за да стигне до тоалетот. Објаснувањето за овие LED ленти беше разгледано во Поглавје 5, точка 5.2.3 и е прикажано на Слика 51 и 52. За уште поголема безбедност при ноќното движење на станарот до тоалетот во Варијанта 1 може да се постави сензор на подлогата од креветот кое ќe се активира и постепено ќе вклучува светлина во моментот кога станарот ќе се исправи на креветот и ќе го допре подот со нозете.

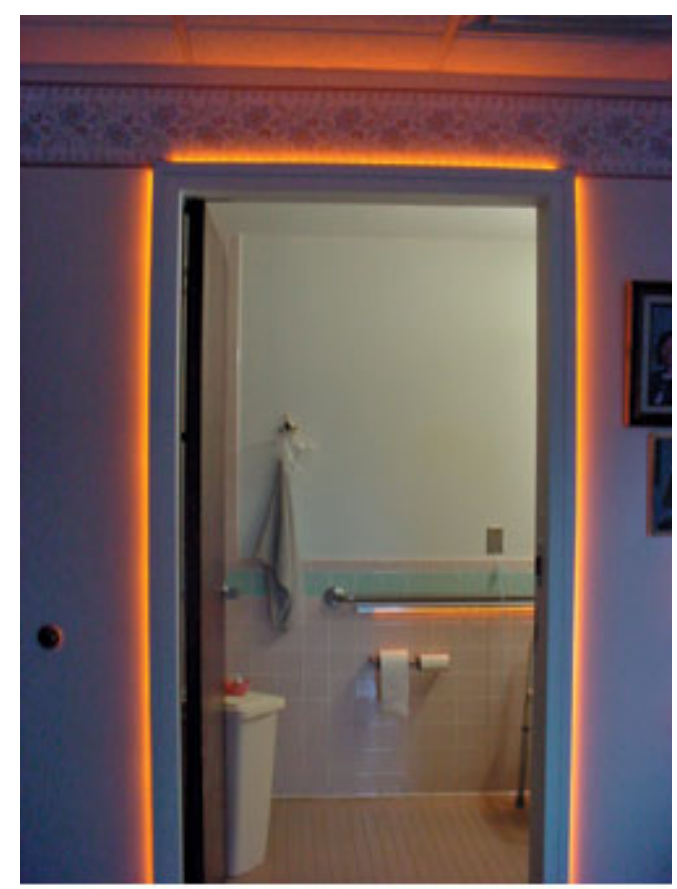

Figure 1.

Слика 51 - LED ленти поставени околу рамка на врата. Извор: Lighting Research Center, (2005), Around the bathroom door frame [ONLINE]. Available at: http://www.ItImagazine.com/article/hot-technologies-advancedlighting-technologies-enhance-resident-care [Accessed 29 April 13]. 


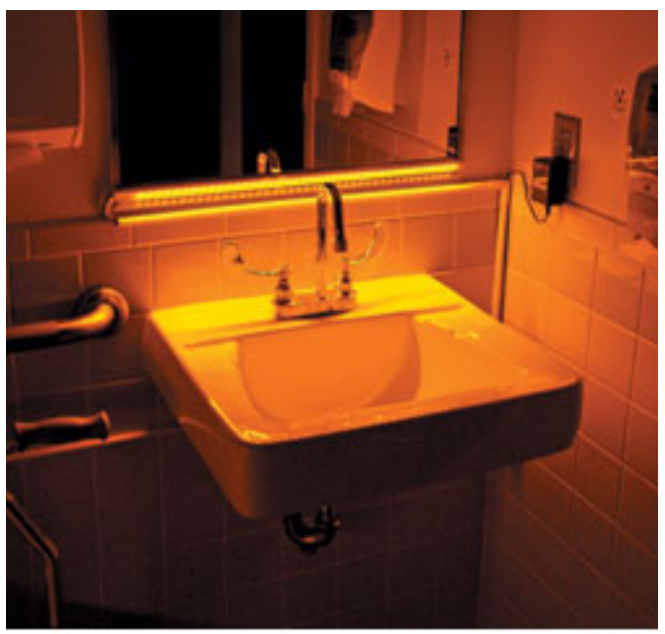

Figure 2.

Слика 52 - LED ленти поставени над мијалникот. Lighting Research Center, (2005), Under the mirror and handrail in the bathroom [ONLINE]. Available at: http://www.ItImagazine.com/article/hot-technologiesadvanced-lighting-technologies-enhance-resident-care [Accessed 29 April 13].

Во сите три варијанти е вклучен дополнителен складишен простор во видот на шкаф или комода со фиоки на којшто би се поставил телевизорот. Единствено би била различна големината на овој дополнителен складишен простор којшто во Варијанта 1 би требало да има минимални димензии (до $30 \mathrm{~cm}$ ) со цел да не претставува пречка во движењето кон креветот. Овде повторно може да се примени препораката на Regnier (2002) за употреба на складишен простор со стаклени врати.

Во Варијанта 3 плакарот, којшто повторно е изработен по мерка, е поставен во катчето за седење и веднаш до него е поставена комода со фиоки на која е поставен телевизорот. Отстранувањето на плакарот од претсобјето овозможува отворање на влезната врата за нешто повеќе од 90 степени. Дополнително на тоа, со новата местоположба на плакарот се задоволуваат две препораки на deLaski-Smith (1998): пред плакарот се добива слободен простор од $120 \mathrm{~cm}$ за удобно користење на плакарот и во близина на плакарот има мебел за седење каде што станарот може да седне или да се придржи при облекувањето.

Во трите варијанти е употребена маска за радијаторот изработена по мерка, со цел да го заштити станарот од повреда од изгореници. Истата маска може да замени ноќно ормарче бидејќи станарот може да го користи горниот дел од маската како подлога за оставање на предмети до креветот. Предлог за изгледот на маската е прикажан на Слика 53. Постојната 
состојба во пределот на прозорецот го попречува неговото слободно отворање поради двете ноќни ормарчиња и столот кои се поставени пред прозорот. Важно е да се напомене дека височината на маската треба да биде под парапетот на прозорецот за да не пречи во отворањето на прозорецот. Од надворешната страна на прозорецот поставена е декоративна решетка изработена од ковано железо поради која прозорецот е безбеден за употреба од станарот.
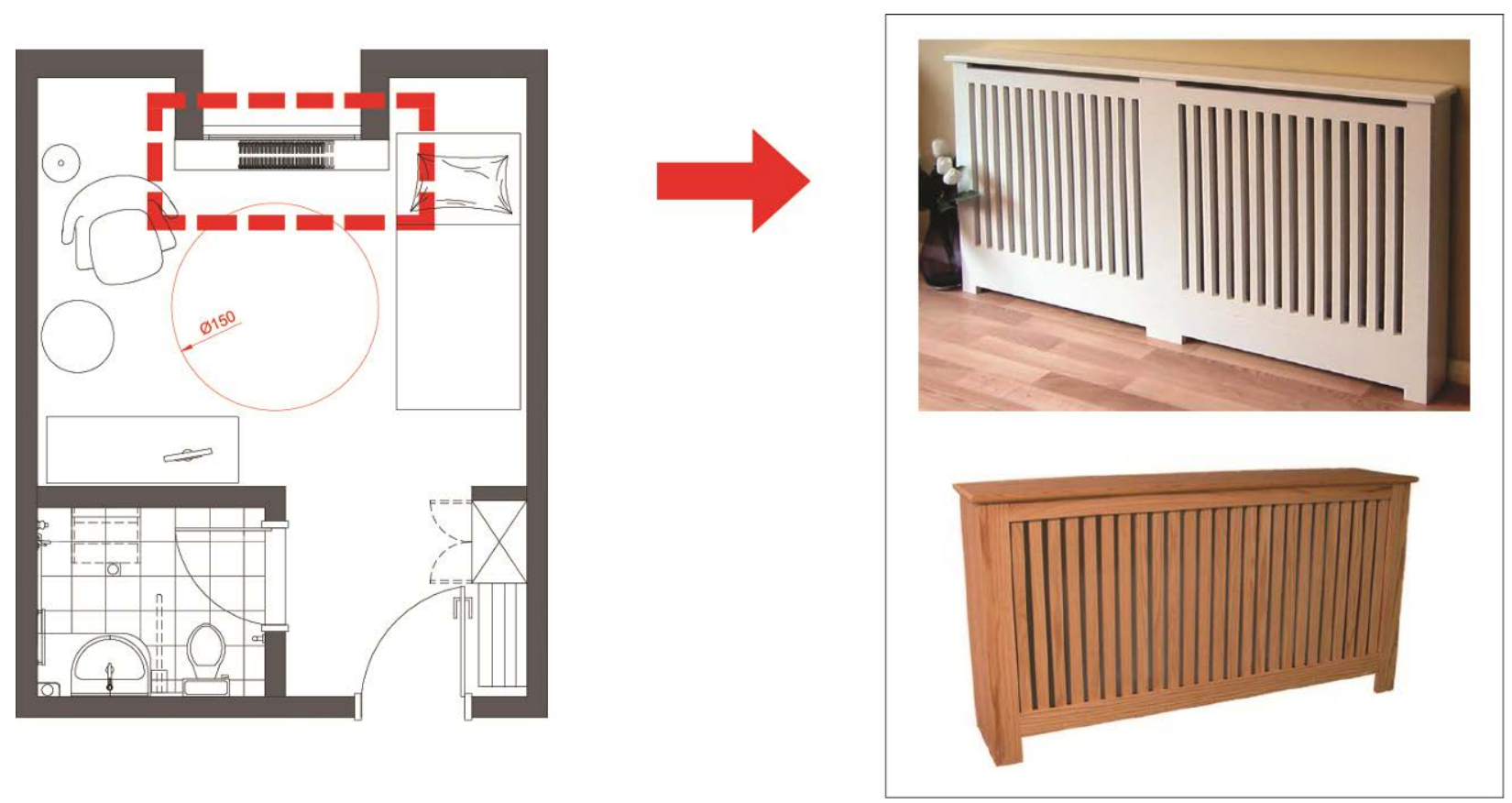

Слика 53 - Декоративна маска за покривање на радијаторот. Извор за маската: Westchester Woodcrafters, (2013), Shaker [ONLINE]. Available at: http://www.westchesterwoodcrafters.com/radiator\%20covers.html [Accessed 17 May 13].

Што се однесува до мебелот за седење, тој е ист во сите сугестии за модификација кои се предложени овде - во оние со помал, како и оние со поголем градежен зафат. Причината за тоа е што неговиот изглед е идеален за употреба од стари лица, земајќи го предвид описот на deLaski-Smith $(1998$, p.4) за карактеристики на стол соодветен за употреба од старо лице со АБ:

- Фотелјата да има ногалки бидејќи на старите лища им е потребен слободен простор под мебелот за седење со што ќе можат да отидат малку поназад со стапалата кога стануваат од седната положба Кога старите лица стануваат од седната положба вообичаено одат малку поназад под столот со стапалата со 
цел стабилно да се исправат од столот. Поради ова имаат потреба од слободен простор под седиштето на мебелот за седење, што значи дека фотелјата во станбената единища треба да има ногалки;

- Наслонот за рацете треба да биде на височина која додека лицето кое седи и ги потпира раџете на наслонот раменищите не се во подигната туку во нормална положба;

- Наслонот за раце треба да биде малку понапред од седиштето ито помага во станувањето;

- Височината на грбот на фотелјата треба да биде доволно висок да може станарот да ја потпира главата;

- Страничните наслони за главата се полезни бидејќи станарот може да задрема на нив;

- Да не се користи мебел за седење со меко седиште бидејки го отежнува стануването;

- Фотелјата треба да биде доволно иврста и стабилна за да не се поместува кога станарот нагло ќе седне на нив или кога ќе се потпира при станувањето.

Пример за мебел за седење кој соодветствува на горенаведениот опис на deLaski-Smith e фотелјата на Слика 54. Бидејќи сепак станува збор за мебел одбран според фотографија, препораката во однос на стабилноста и мекоста на седиштето не е проверена. Фотелјата од фотографија претставува само илустративен пример за соодветен мебел за седење на стари лица.

Покрај мебелот за седење кој треба да ги поседува горенаведените карактеристики, станарот се охрабрува да донесе свој мебел во станбената единица (по примерот на НН) при што треба да се води сметка за одблесокот којшто мебелот може да го предизвика, т.е. да не се внесува мебел изработен од материјал кој создава одблесок или кој содржи елементи со присуство на одблесок (како на пример, стаклени врати од витрина). 


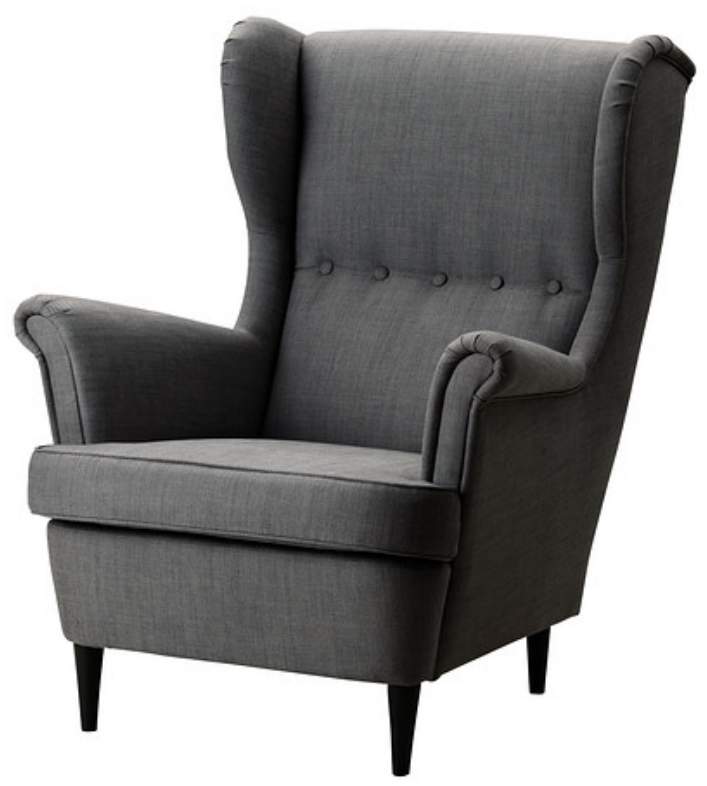

Слика 54 - Предлог за фотелја која ги задоволува условите за употреба од стари лица. Извор: ІКЕА, (2013), STRANDMON Wing chair, Svanby gray [ONLINE]. Available at: http://www.ikea.com/ca/en/catalog/products/90251659/ [Accessed 30 March 13].

Во просторот за дневен престој се препорачува и употребата на соодветна маса која станарот ќе може да ја употребува за оставање на предмети. Масата треба да има соодветна височина, односно станарот да може да остава предмети на неа додека се наоѓa во седната положба. Исто така е важно масата да не биде поставена пред фотелјата бидејќи на тој начин ќе претставува пречка која станарот при секое седнување ќе се обидува да ја поттурне. Joule и Levenson (2009) препорачуваат сиот мебел да биде повлечен на страна до зидовите и да нема никакви пречки во линијата на движење.

\section{Сугестии за можна модификација на тоалетот во станбените единици}

Со оглед на тоа што за време на посетата во домот МТ тоалетот не беше детално измерен поради ограничениот пристап при снимањето на просторот, но и поради тоа што не е позната инсталацијата во тоалетот, сугестиите кои ќе бидат наведени овде ќе бидат поопшти. Во постојната состојба на тоалетот прикажана на Слика 46 може да се забележи дека тоалетот е значително помал од препорачаниот слободен простор со дијаметар од 1500 мм за завртување на инвалидска количка. Оваа одлика на тоалетот го усложнува правењето на распоред кој ќе биде соодветен за употреба од лица кои имаат потреба од 
инвалидска количка. Бидејќи се работи за модификации со помал градежен зафат, сугестиите не вклучуваат промени во распоредот на опремата во тоалетот и главно се состојат од додавање на одредени елементи.

Во сите варијанти на сугестии за можна модификација со помал градежен зафат каде што не може да се промени начинот на отворање на вратата на тоалетот поради непосредната близина на влезната врата во станбената единица, неопходно е вратата да има можност за отворање навнатре и на надвор истовремено. Целта на ова двојно отворање е поради можноста станарот да падне додека се наоѓа во тоалетот и да ја блокира вратата при што персоналот нема да биде во можност да ја отвори и да помогне (Brawley, 2006).

Бидејќи малиот простор во тоалетот на станбената единица не дозволува поставување на хоризонтални држачи за раце околу тоалетната шолја на димензии препорачани според Правилникот за начинот на обезбедување на непречен пристап, движење, престој и работа на лицата со инвалидност до и во градбите (Службен весник на РМ бр.25/10, 2010), може да се разгледаат други опции кои не се во правилникот но ја имаат истата функција - да обезбедат безбедно станување и седнување на тоалетна шолја. Со оглед дека не е познато каква е конструкцијата на зидот зад тоалетот, а со тоа е непозната и неговата издржливост, може да се монтира држач за раце кој се прикачува во подот наместо во sидот и се подига кога не е во употреба (Слика 55). Подигањето е полезно од аспект на заштеда на простор и исклучување на веројатноста за судир со држачот при движењето кон мијалникот.

Тоалет кој ги содржи сите неопходни држачи за раце најчесто има институционален и непријатен изглед. Особено кога се употребени типичните алуминиумски држачи. Со цел да се избегне таков изглед може да се употребат држачи во живи бои кои можеби ке го разведрат тоалетот. Интересен ваков пример е тоалетот прикажан на Слика 56. Овој изглед прикажан на примерот, може да се постигне со поставување на следните помошни елементи во портокалова боја: држач за течен сапун прикачен над мијалникот (Слика 57), полици за козметика прикачени до мијалникот (Слика 58) и до тушот (Слика 59), држач за пешкир прикачен на предниот дел од конзолниот елемент на мијалникот или на sидот до мијалникот (Слика 60). 


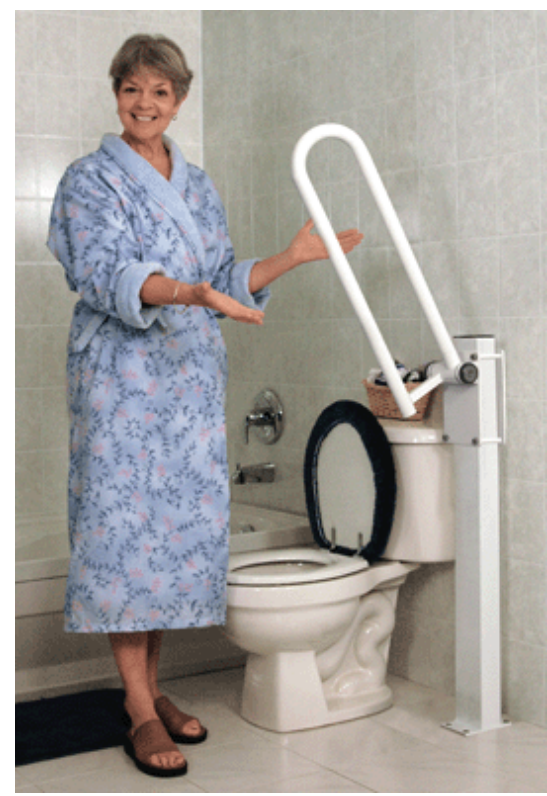

Слика 55 - Држач за раце на подигање, монтиран во под. Health Craft, (2011), P.T. Rail ${ }^{\mathrm{m}}$ Floor Mast [ONLINE]. Available at: http://www.healthcraftproducts.com/ptrailfloormast.htm [Accessed 01 May 13].

Сите овие елементи се илустрирани само поради нивната боја како пример за создавање на контраст со постојните бели плочки во тоалетот. Исклучително е важно истите да бидат многу цврсти и стабилни. Многу често, кога старите лица имаат потреба од потпирање го користат тоа што е најблизу до дофат (Sanford, 2002) и затоа треба да се внимава на стабилноста на елементите и држачите низ целиот простор. Поради тоа, постојниот држач за пешкирот до мијалникот да се замени со држач за раце кој истовремено ќе го држи пешкирот (Слика 61).

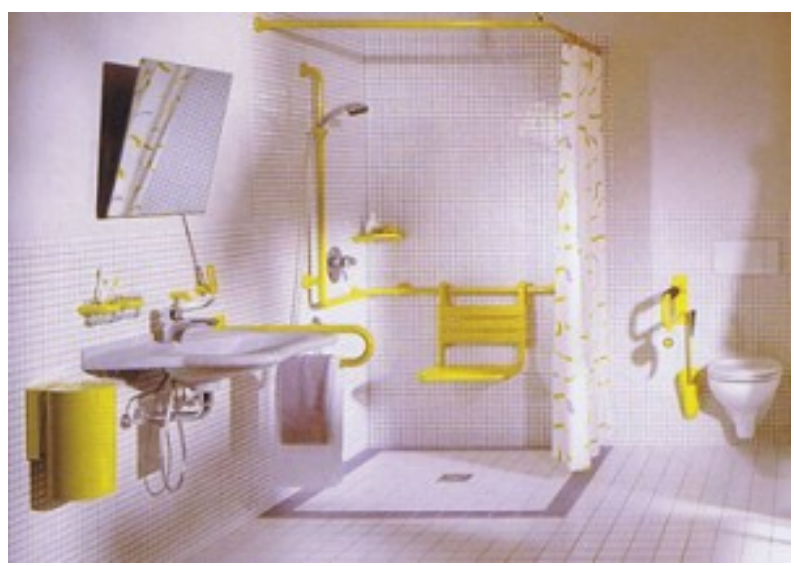

Слика 56 - Пример за држачи во боја. Извор: In-LawSuite.com, (2012), Bathroom Design For Mother In Law Suites [ONLINE]. Available at: http://in-lawsuite.com/mother-in-law-suite-bathroom-design/ [Accessed 09 May 13]. 


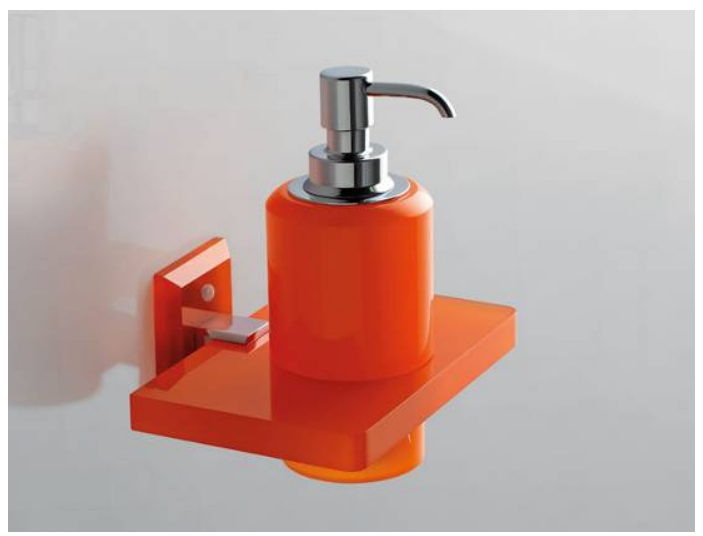

Слика 57 - Портокалов држач за течен сапун. Извор: Toscana luce, (2013), G323/c/aR [ONLINE]. Available at: http://www.toscanaluce.it/images/grip/big/grip_5.jpg [Accessed 09 May 13].

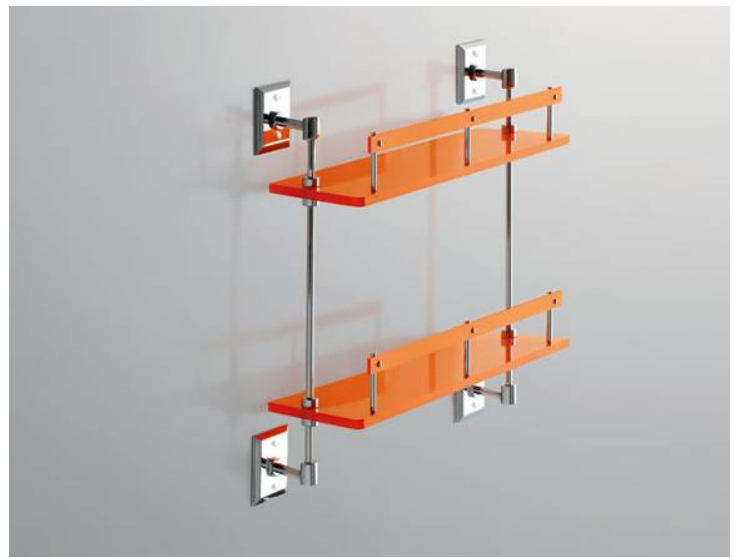

Слика 58 - Портокалов држач за козметика до мијалник. Извор: Toscana luce, (2013), G242/c/aR [ONLINE]. Available at: http://www.toscanaluce.it/images/grip/big/grip_17.jpg [Accessed 09 May 13].

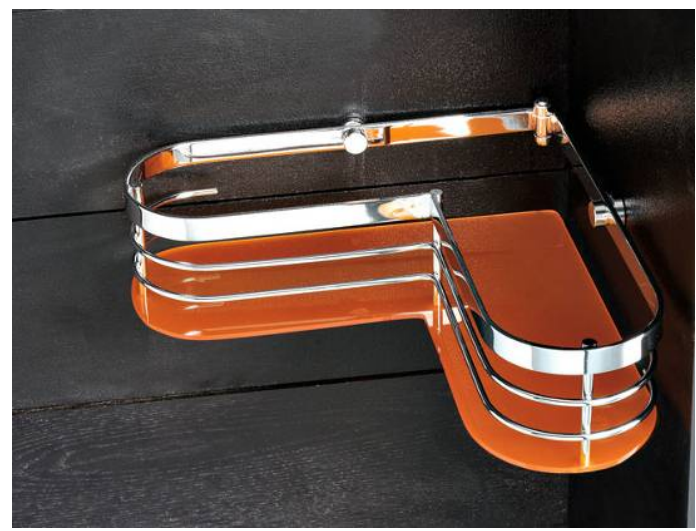

Слика 59 - Портокалов држач за козметика до туш. Извор: Toscana luce, (2013), 1311/C/AR [ONLINE]. Available: http://www.toscanaluce.it/images/accessori-doccia/big/accessori-doccia-7.jpg[Accessed 09May13]. 


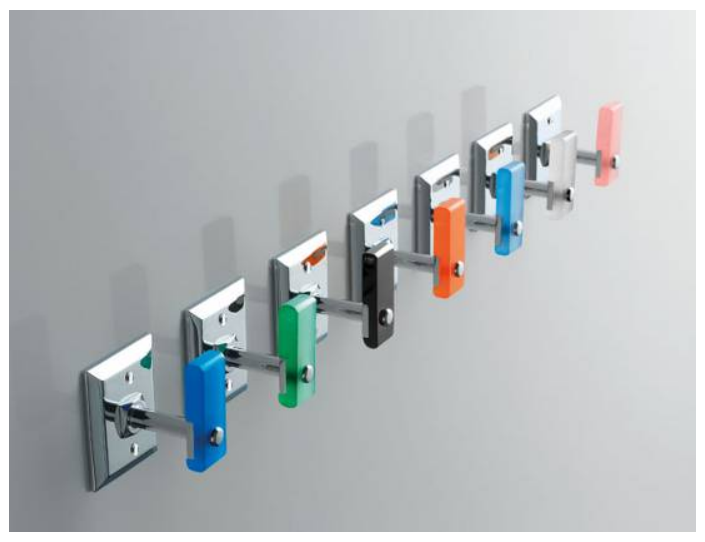

Слика 60 - Портокалова закачалка. Извор: Toscana luce, (2013), G204 [ONLINE]. Available at: http://www.toscanaluce.it/images/grip/big/grip_18.jpg [Accessed 09 May 13].

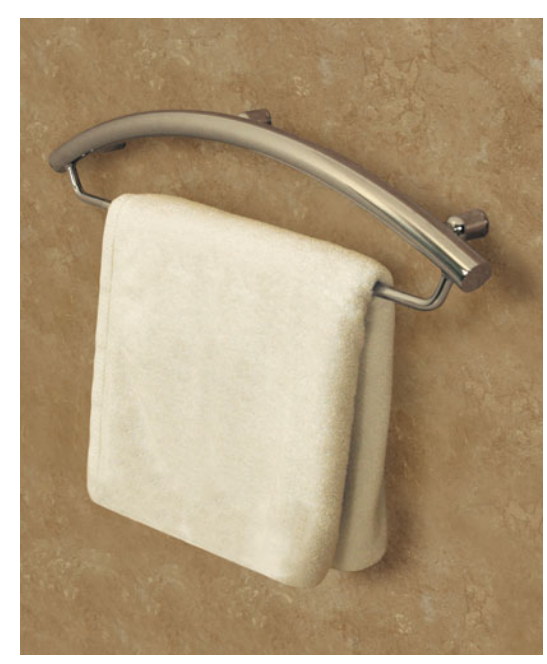

Слика 61 - Држач за раце кој истовремено е држач за пешкир. Извор: Invisia Collection, (2012), TOWEL BAR with Integrated Support Rail [ONLINE]. Available at: http://www.invisiacollection.com/towelbar.html [Accessed 02 May 13].

Пределот на тушот се одликува со голема веројатност за лизгање на станарот при капењето поради присуството на лизгави керамички плочки и отсуството на држачи за раце во непосредна близина. Состојбата а на тушот во тоалетот може да се подобри со поставување на водоотпорно седиште на кое станарот ќе може да се искапе во седната положба, но неопходно е и поставувањето на држачи за раце на двата sидови околу тушот. На Слика 62 е прикажан пример за изглед на такво седиште за капење кое се монтира на sидот и се подига кога не е во употреба. Покрај овој предлог, како помала интервенција од монтирањето на седиште, на местото под тушот може едноставно да се остави пластичен стол за измивање. Употребата на седиште на подигање е прикладно за малиот простор во 
тоалетот во станбените единици поради тоа што би заштедило повеќе простор отколку поставување на стол за измивање или монтирање на седиште кое не се подига.

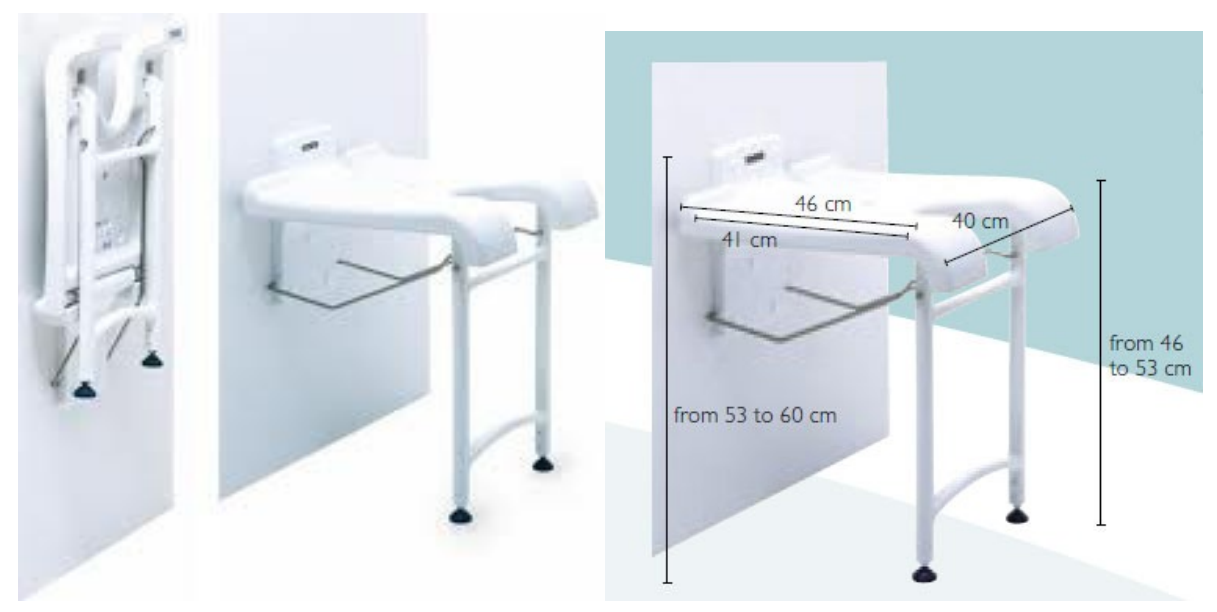

Слика 62 - Седиште за капење кое се подига. Извор: Mobility Smart, (2012), Aquatec Sansibar Wall Mounted Shower Stool [ONLINE]. Available at: http://www.mobilitysmart.cc/aquatec-sansibar-wall-mounted-showerstool.html [Accessed 17 May 13].

Огледалото кое се наоѓа над мијалникот во тоалетот е поставено на височина недостапна за лица во инвалидска количка. Тоа може многу лесно да се замени со калено огледало, кое ќе биде поставено на височина не повеќе од $100 \mathrm{~cm}$ од подот со цел да може да се користи од лице во инвалидска количка и да достига височина до $180 \mathrm{~cm}$ за употреба од лице кое не е користи количка. Бидејќи обезбедувањето на електрична струја точно над огледалото претставува поголем градежен зафат, може да се постави лустер со насочено осветлување на местото над мијалникот, како примерот на Слика 63.

Осветлувањето во станбената единица е нерамномерно распространето при што се создаваат длабоки сенки на одредени места во собата и светлото во просторот зависи само од централното плафонско осветлување. Поради тоа во двете групи на сугестии за модификација се поставени дополнителни извори на светлина, како на пример столни ламби покрај креветот, покрај фотелјата и на комодата наспроти фотелјата. Видовите на осветлување се идентични во сите групи на сугестии, единствено што понекаде се разликува местоположбата. 


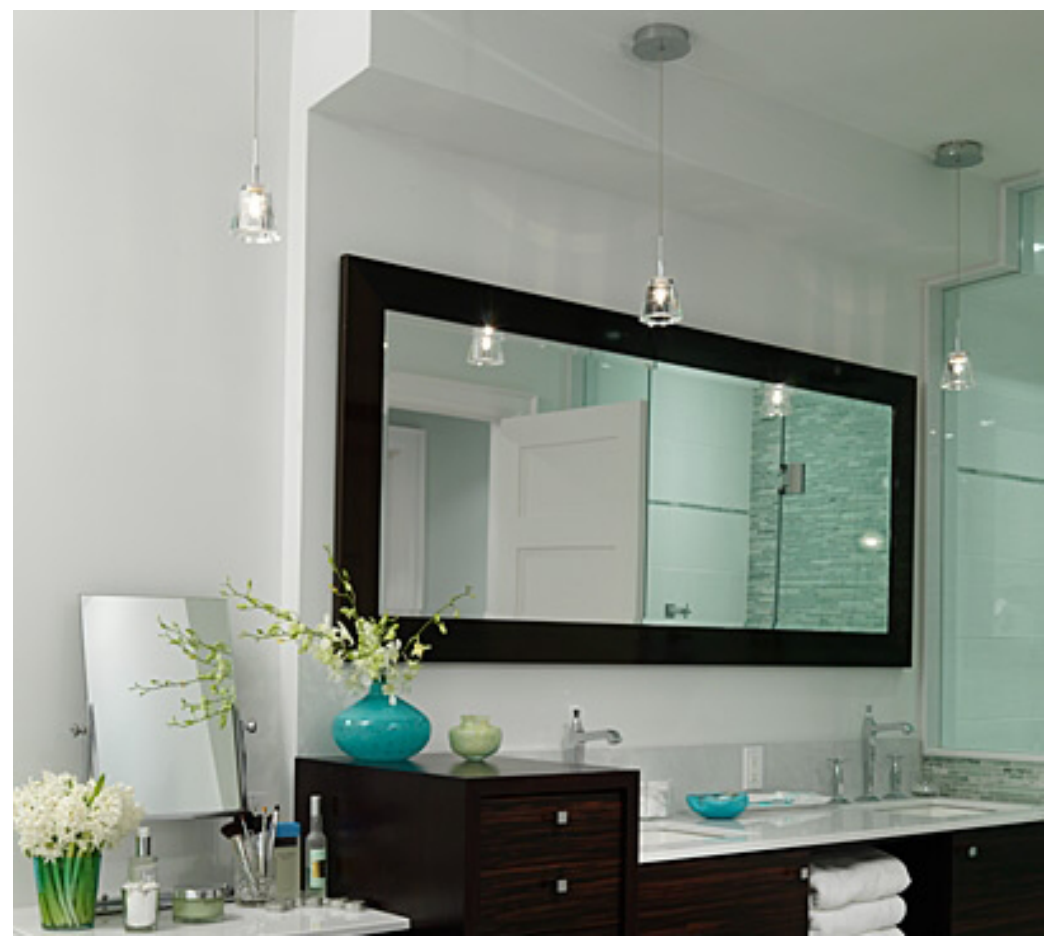

Слика 63 - Лустер поставен над мијалникот. Извор: Sarah Richardson Design, (2013), Sarah's House for HGTV Bathroom [ONLINE]. Available at: http://www.sarahrichardsondesign.com/portfolio/project/sarahshouse/bathroom1 [Accessed 17 May 13].

Предложените местоположби на новите светлосни извори за Варијанта 2 и 3 се прикажани на Слика 64. Предложените модели на светла од сликата само покажуваат каков вид на осветлување може да се постави на одреденото место. Покрај креветот која станарот може да се донесе столна ламба ја користел долго време во својот дом што ќе го олесни ноќното вклучување при потреба од станување од креветот за да се спречи појавата на паѓање во темница. Во спротивно, препорачливо е да се постави ламба која лесно ќе се вклучува, како што е примерот прикажан на Слика 64. И во двата случаи, неопходно е ламбата да биде прицврстена за подлогата поради можноста истите да бидат турнати од станарот. Зад фотелјата во просторот за дневен престој во секоја варијанта од секоја група на сугестии се наоѓa ламба која ќе може да се користи за читање, ќе може светлината да се насочи во потребната насока и ќе се вклучува со повлекување на жица. На зидот зад телевизорот може да се постави дополнително амбиентално осветлување кое ќе има декоративна цел, но и ќе дава свој придонес во создавањето на рамномерно осветлување во просторот. 


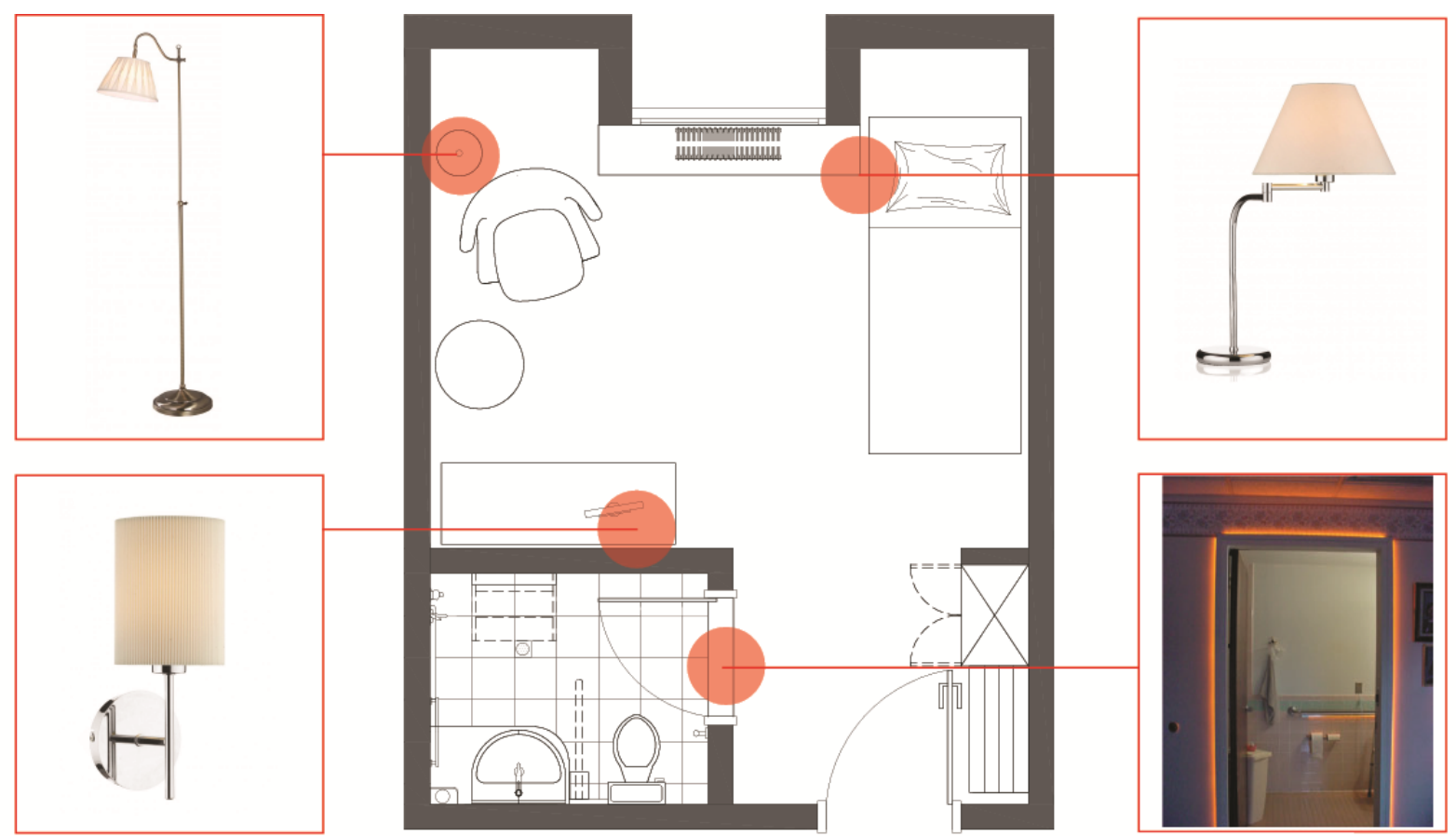

Слика 64 - Местоположба на дополнителни светлосни извори за можна модификација со помал градежен зафат. Извор: авторот.

Пребојувањето на зидовите е уште една сугестија која е заедничка за сите варијанти на двете групи на сугестии, како и отстранувањето на иверките кои се поставени по должината на зидовите во просторот за дневен престој и спиење (Слика 65). Бидејќи во Поглавје 5 утврдивме дека бојата која се употребува во просторот зависи од личните преференции на индивидуата, најдобар пристап е боењето на sидовите во неутрални земјени тонови. Може да биде интересна употребата на тапети при што треба да се внимава на шарите, поточно да не се употребуваат воочливи шари во дизајнот бидејќи може ги дезориентираат станарите (RIBA, 2011). На одредени места каде што има потреба од создавање на воочлив контраст за потенцирање на значајни елементи од просторот кои се наменети за станарите, како што е случајот со прекинувачите за светло во претсобјето, може да се употребат и потемни тонови на зидот (како на пример кафена). 


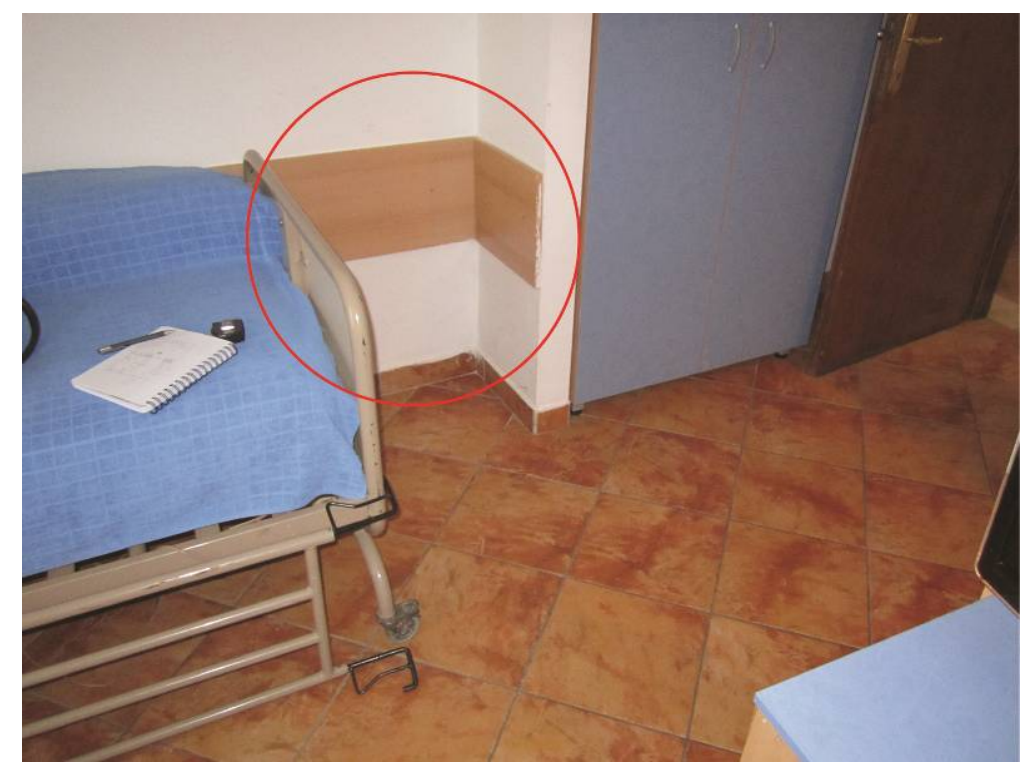

Слика 65 - Иверици поставени по должината на зидовите во просторот за дневен престој и спиење. Извор: авторот.

\section{2 Сугестии за можна модификација на простори во домот Мери Терзиева за потребите на лицата со Алцхајмерова Болест со поголем градежен зафат}

Сугестиите за модификација на домот МТ со поголем градежен зафат опфаќаат поместување на одредени архитектонски елементи во станбената единица како и некои други поголеми промени. Сугестиите коишто се наведени овде ќе бидат поделени на ист начин како и претходните сугестии, односно ќе бидат вклучени три можни варијанти кои помалку или повеќe ќe се разликуваат помеѓу себе. За разлика од варијантите во претходната група сугестии коишто беа меѓусебно компатибилни, овие варијанти не е практично да се комбинираат помеѓу себе.

\subsection{1 Станбена единица}


Сугестии за можна модификација на просторот во домот Мери Терзиева за потребите на лицата со Алцхајмерива Болест со поголем градежен зафат

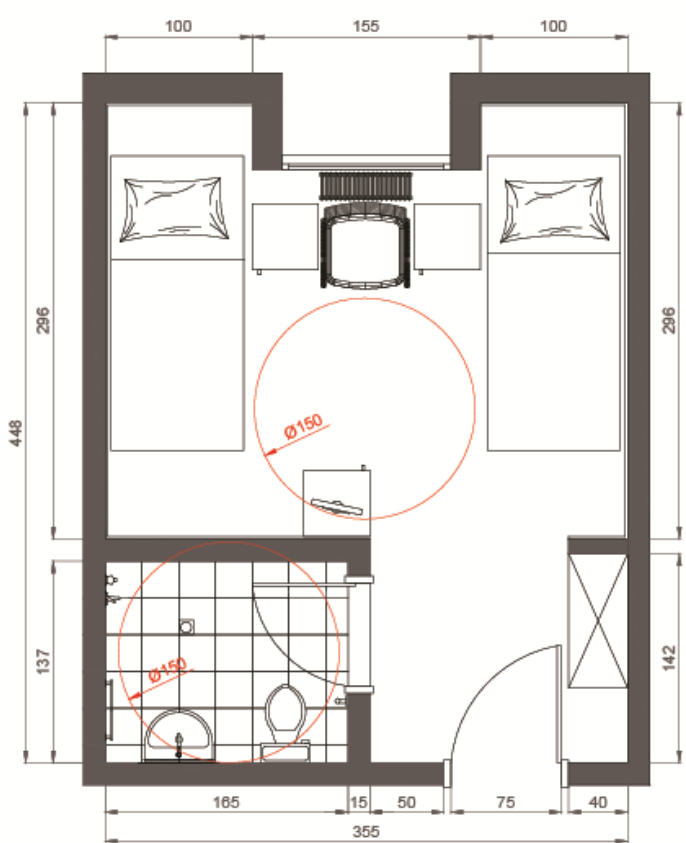

постојна состојба

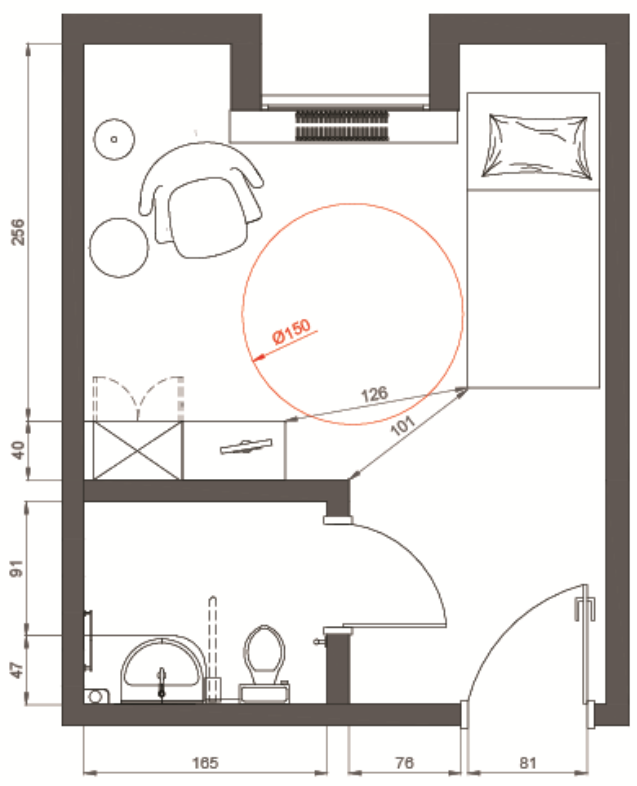

варијанта 2

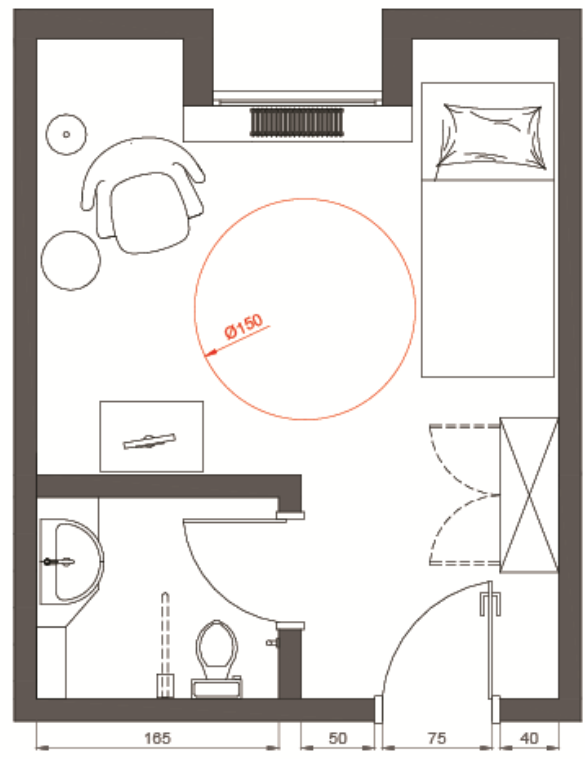

варијанта 1

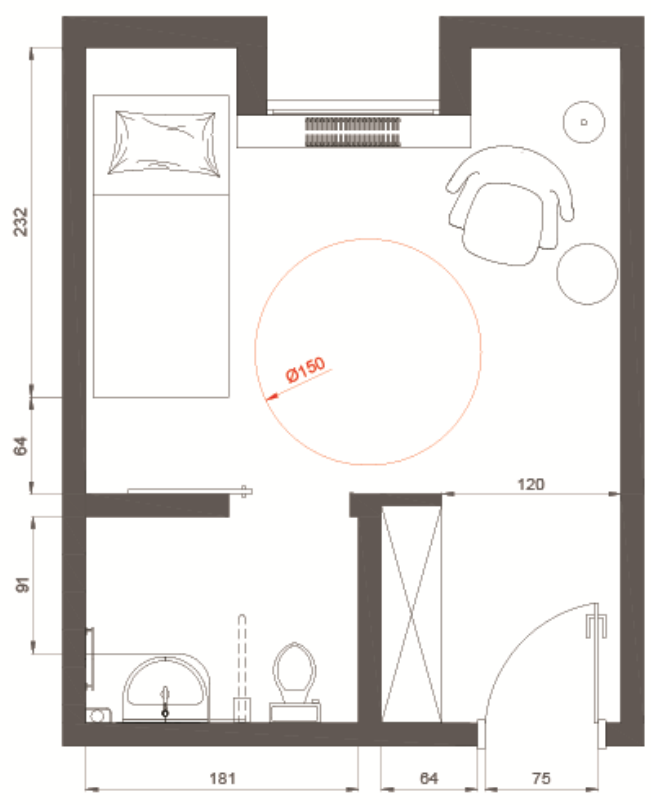

варијанта 3

Слика 66 - Сугестии за можна модификација на простори во домот МТ со поголем градежен зафат изразени преку три варијанти. Извор: авторот. 
Можната промена која ја предложуваат варијантите на модификациите со поголем градежен зафат имаат заедничка особина во отстранувањето на преградниот sид којшто се наоѓа помеѓу плакарот и креветот, сѐ со цел да се овозможи поголем пристап при отворањето на влезната врата. Во Варијанта 1 тоа поместување се искористува за поместување на постојниот плакар кон креветот со што се зголемува степенот на отворање на влезната врата. Доколку изгледот на синиот плакар не соодветствува со дизајнот на собата откако ќе биде префарбана во неутрални тонови, тогаш може да се заменат само вратите на плакарот со што тој ќе добие сосема нов изглед. Покрај отстранувањето на преградниот мид до плакарот, останатите зидови во Варијанта 1 го задржуваат истото место. Распоредот на мебелот во станбената единица во просторот за дневен престој и спиење е сличен како во Варијанта 2 и 3 во групата на сугестии со помал градежен зафат.

Во Варијанта 2 и 3 со поместувањето на отворот на влезната врата кон десниот мид се добива поголема можност за модификација на други елементи од просторот. Како на пример, во Варијанта 2 се променува начинот на отворање на вратата од тоалетот поради веќе споменатите безбедносни причини за избегнување на блокиран пристап во случај на паѓање на станарот од другата страна на вратата. Отворањето на вратата кон надвор во оваа варијанта не ја попречува линијата на движење од влезот и овозможува поглед кон тоалетот од креветот. Додека пак, во Варијанта 3 по преместувањето на влезниот отвор се поместува и преградниот sид на тоалетот кон претсобјето за 15см. Ова поместување создава прилика за отворање на нов отвор за врата од страната на просторот за дневен престој и спиење. Вратата во овој случај се предлага да биде лизгачка врата со шибер систем (Слика 67). Според Brawley (2006) употребата на овој вид на врати наоѓa се поголема примена во домовите за стари лица со АБ поради тоа што овозможуваат чист влез и се полесни за употреба од другите лизгачки врати. Меѓутоа, важно е да се напомени дека поместувањето на зидот кон претсобјето е можно само во Варијанта 3 каде што креветот се наоѓа на левата страна од собата. Во спротивно, во другите варијанти каде креветот е од десната страна на собата, ќе се намали просторот за поминување помеѓу аголот на зидот и аголот на креветот. 


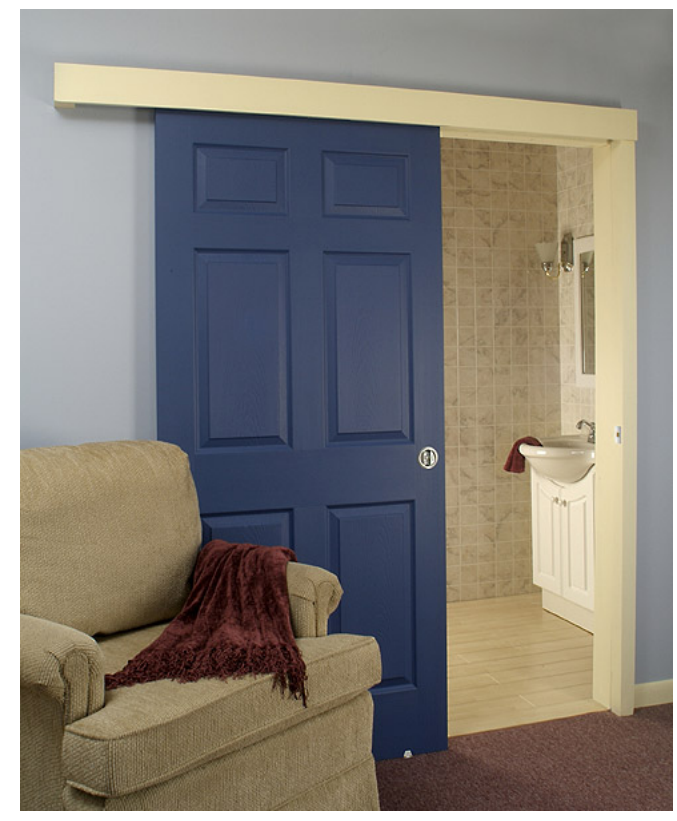

Слика 67 - Врата со шибер систем. Извор: MarketKonekt, (2013), Шибер систем - АВАК 100 [ONLINE]. Available at: http://mk.marketkonekt.com/mk/shiber-sistem-abak-100?productid=vq6 [Accessed 17 May 13].

Варијанта 3 се разликува од останатите варијанти во тоа што плакарот е вграден во ниша во ходникот и не е предвидено место за телевизор во собата, од причина што во насоката во која се поставени креветот и местото за седење нема слободен sид на којшто може да се постави комода со ТВ уред. Меѓутоа, доколку станарот инсистира може да се постави комода до местото за седење на којашто телевизорот ќе се ротира во зависност од тоа дали станарот гледа од кревет или од фотелја. Бидејќи поставувањето на комода во распоредот прикажан во Варијанта 3 може да претставува физичка пречка во просторот, може да се монтира ТВ уред на sидот каде што е вграден плакарот. Но и оваа опција има свои слаби страни поради тоа што овој начин на поставување на телевизорот на sид може да ги асоцира станарите на болнички престој. Плакарот во претсобјето на оваа варијанта се предлага да биде вграден во ниша во ходникот и да биде изработен по мерка чија што широчина нема да надмине $40 \mathrm{~cm}$ со цел да остане слободен простор од $120 \mathrm{~cm}$ за поминување во ходникот. Покрај негативните особини, оваа варијанта има и позитивни страни бидејќи се ослободува поголемо слободно движење низ собата и се овозможува директен пристап до тоалетот кој ќе ја олесни ориентацијата особено при потребата во доцните вечерни часови. 
Поради веќе наведените ограничувања во тоалетот, според кои не се задоволени основните стандарди за пристапен тоалет овде ќе бидат наведени минимални подобрувања преку кои ќе се подобри употребливоста на постојниот простор со кој се располага во тоалетот. Во трите варијанти клучната промена е отстранувањето на тушот и керамичките плочки, по примерот на тоалетот во домот VC. Бидејќи домот МТ овозможува на своите станари капење во пристапен тоалет, тогаш постои можноста да се отстрани тушот од собата. Во тој случај подната облога од керамички плочки може да се замени со PVC облога. Новата подна облога може да биде во боја контрастна со бојата на опремата во тоалетот, што ќе им помогне на станарите со нарушување на видот. По отстранувањето на sидните керамички плочки во тоалетот се препорачува употребата на внатрешна мидна боја со фунгицидно својство и заштита од влага. Како пример за таков вид на боја која ги содржи наведените својства и е наменета за употреба во бањи може да се посочи бојата на Слика 68, која како дополнување на претходно наведените карактеристики дозволува и бришење на зидните површини со медицински дезинфекциски средства. Што се однесува до селекцијата на тоновите на бојата, се препорачува единствено подот во тоалетот да биде потемен за да се создаде контрастот со санитаријата, додека мидовите бидат обоени во посветли тонови за да се спречи појава на визуелно намалување на и онака малиот простор во тоалетот.

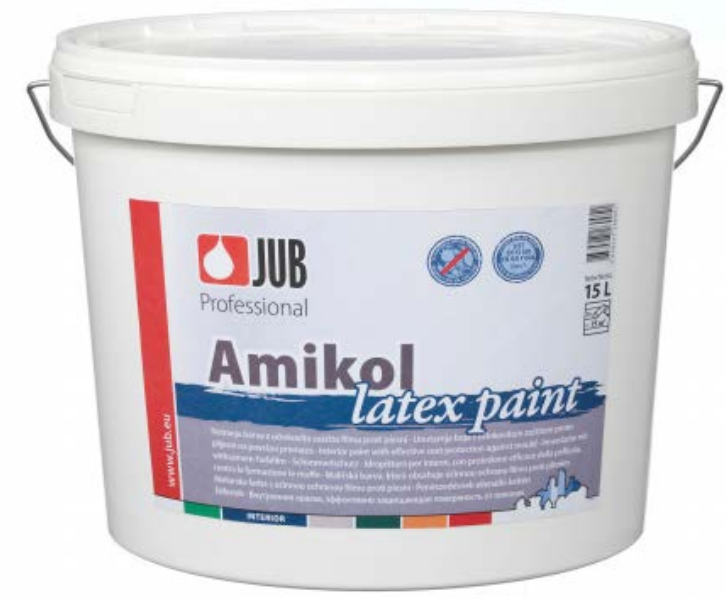

Слика 68 - Внатрешна зидна боја со фунгицидно својство. Извор: ЈУБ, (2013), Амикол [ONLINE]. Available at: http://www.jub.com.mk/mk-izdelki/mk-izdelki-za-problematicne-povrsine/mk-amikol/?cat=3191 [Accessed 17 May 13]. 
Меѓутоа, иако таа опција не е прикажана во овие варијанти, распоредот на опремата во тоалетот може да се задржи како во постојната состојба, со тоа што како дел од интервенциите со поголем градежен зафат може да се променат плочките, санитаријата и да се промени местоположбата на сифонот кој би се поставил колку е возможно поблиску до аголот со нагиб за одвод на водата. Во овој случај, со поместувањето на sидот кон претсобјето ќе се добие поголем простор покрај тоалетната шолја каде што ке биде поставен држачот за раце на подигање.

Во предложениот распоред на Варијанта 1 мијалникот се наоѓа на местото на тушот со цел да се искористи инсталацијата за топла и ладна вода. Бидејќи веќе се демонтира постојниот мијалник, со повторното монтирање тој може да се вгради во конзолна плотна чијашто долна страна е покриена со капак за покривање на одводните цевки, којшто е закосен за да овозможи пристап за лице со инвалидска количка. Начинот на овој вид на покривање на цевките под мијалникот е прикажан на Слика 69.

Fig. 4 Lavatory Clearances.

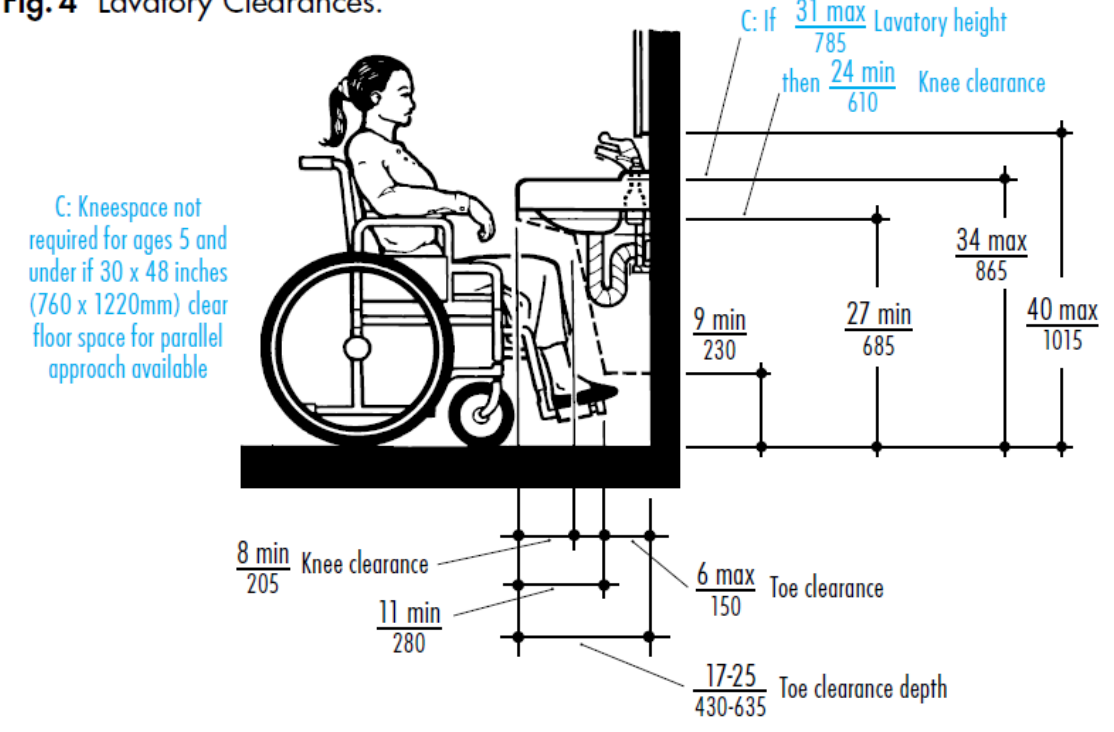

Слика 69 - Конзолен мијалник со закосена долна страна за пристап на лице во инвалидска количка. Извор: Bobrick, W.E., 2007. Barrier-Free Washroom Planning Guide. Bobrick Washroom Equipment, Inc., BFPG$07,1-24$.

Што се однесува до можните модификации за осветлувањето на просторот, во овие сугестии се предлага истото дополнително осветлување наведено во сугестиите со помал градежен зафат. Меѓутоа, бидејќи се работи за модификации со поголем зафат овде може 
да се предложи поставување на странични светла до огледалото над мијалникот, насочено светло над мијалникот и доколку останува тушот, насочено светло над него. Страничните мидни светла можат да имаат амбиентална функција и како илустрација за ваков вид на осветлување во тоалетот може да послужи Слика 70. Од сликата може да се забележи дека овој вид на осветлување има домашен карактер, за разлика од неонското осветлување на Слика 71 кое има институционален изглед. Меѓутоа двата вида на светлосни извори во комбинација ја задоволуваат препораката на Regnier (2002) за употреба на мешавина од различни извори на светлина: природна светлина; вградени флуоресцентни и ламби со вжарено влакно; мидни, подни и столни ламби; плафонски светла и индиректни вградени светла во ниша на плафонот. Сугестиите кои што се однесуваат за пребојувањето на sидните површини во станбената единица се истите како и во претходните сугестии со помал градежен зафат. Повторно е важно да се спомне создавањето на контраст помеѓу елементите кои станарот треба да ги користи и нивната позадина. Но, да се внимава да не се употребуваат посветли тонови од темните бои наспроти потемни тонови од светлите бои при создавање на контраст за лица со АБ (Brawley in Tofle et al., 2004).

Во зависност од можноста на домот, во станбените единици може да настанат и некои други промени кои не беа дискутирани погоре, како на пример: отстранување на плочките во просторот за дневен престој и спиење со цел да се затопли просторијата физички но и визуелно; поставување на подно греење во тоалетот; поставување на сензори кои ќе го регистрираат излегувањето на станарот од собата во ноќните часови; во зависност од постојната sидна конструкција во тоалетот, можеби има потреба од дополнително зајакнување на sидовите со носачи за поголема носивост при монтирање на безбедносни држачи за раце.

Промените кои ќе се добијат со примена на некои од предложените можни интервенции на станбените единици во домот МТ не треба да се третираат како конечни. Тие треба постојано да се надградуваат и да бидат во тек со новите истражувања и препораки. Важно е да се напомени дека при примената на модификациите со минимален градежен зафат може да се преземат и некои сугестии од предложените модификации со поголем зафат и обратно. Одредени елементи од предложените варијанти може меѓусебно да се надополнуваат како што е споменато во описот на сугестиите. 


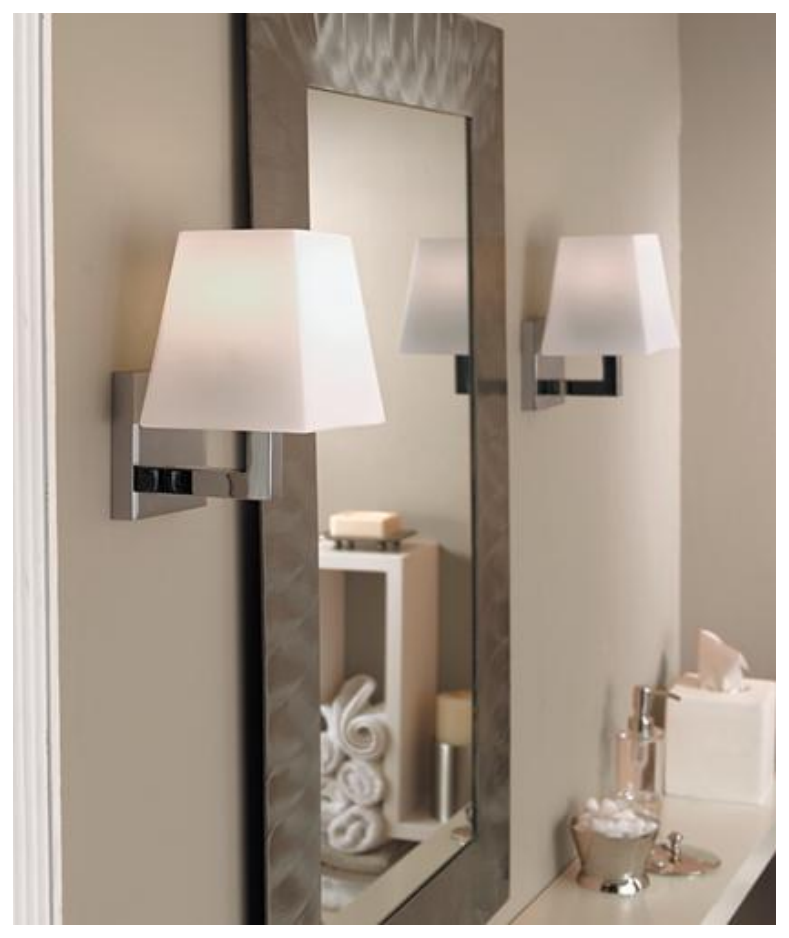

Слика 70 - Чидни ламби до огледалото во тоалетот. Извор: Lamp Plus, (2012), Bathroom design with contemporary lighting [ONLINE]. Available at:

http://image.lampsplus.com/is/image/scenes/38589ven1.fpx?qlt=75\&wid=611\&hei=500\&fit=constrain\&fmt=jp eg [Accessed 18 May 13]

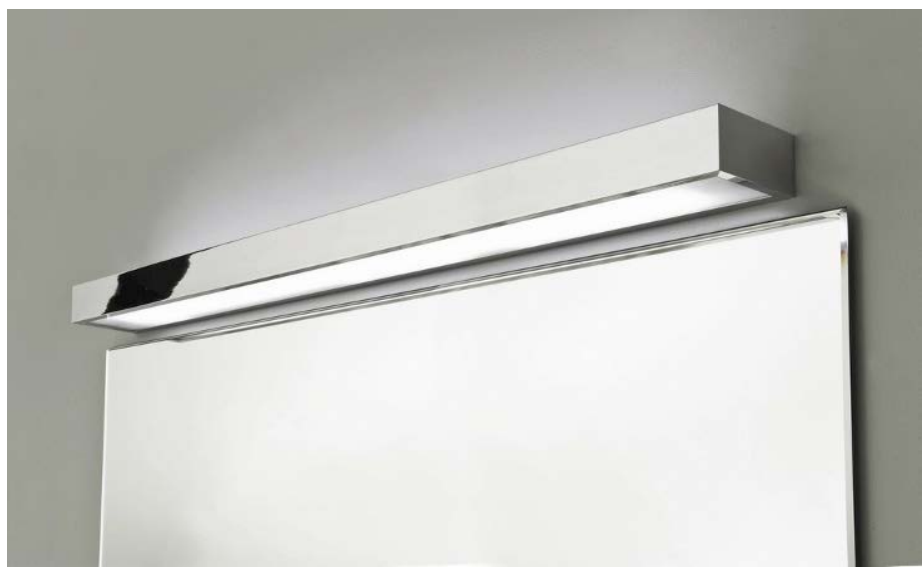

Слика 71 - Насочено неонско осветлување над огледалото во тоалетот. Извор: Online Lighting, (2013), Astro 0661 Tallin 600 Chrome Mirror Light [ONLINE]. Available at: http://www.onlinelighting.co.uk/shop/bathroomlighting/mirror-lights/astro-0661-tallin-600-chrome-676221.html [Accessed 18 May 13]. 


\section{ЗАКЛУЧОЦИ}

Оваа студија на случај ги истражуваше аспектите поврзани со внатрешното уредување во домови кои се наоѓаат во Торонто и Скопје. При разгледувањето на ентериерот во домовите беа идентификувани значајни аспекти за тоа како секој од домовите се справува со вообичаените критични појави во дизајнот на просторот за стари лица со пречки во помнењето. Со тоа, студијата приложува скромен пример за начините на кои се сместувани лицата со АБ во моментов паралелно во Торонто и во Скопје.

Кај трите снимени домови беше забележан обид да се намали институционалниот изглед кој вообичаено се забележува во објектите за колективно домување. Фактот што трите домови имаат избор помеѓу еднокреветни и двокреветни станбени единици укажува на тоа дека институциите ја разбираат потребата од самостојност и приватност на станарите.

При анализирање на резултатите од снимањето на домовите и непосредниот преглед на стручна литература на темата, беше донесен заклучокот дека домовите за нега на овие лица се очекува да ги задоволат нивните основни потреби, кои се променуваат во зависност од стадиумот на болеста во кој се наоѓаат и истовремено да бидат адаптабилни заради можните промени на состојбата поради кои би имале потреба од мобилни помагала. Поедноставно кажано, еден простор за лица со АБ се очекува да биде флексибилен за можни идни промени во состојбата на станарот.

Уредувањето на ентериери за лица со АБ коешто е презентирано во оваа студија има за цел да ја зголеми независноста на станарот при изведувањето на секојдневните активности, што е можно подолго да се одложи зависноста од помош од друго лице и да се подобри благосостојбата на лицето за време на престојот во домот. Успешното уредување и опремување на внатрешниот простор во домот не само што ќе одговори на основните потреби на станарот, туку можеби ќе делува на одлуката на блиските да го одбере токму тој дом. Приложените сугестии за модифицирање на просторот во домот МТ можат да послужат како урнек и инспирација за примена на овој пристап во сите оние средини во РМ кои се наменети за домување на лица со АБ. 


\section{Препораки за идни истражувања}

При пополнувањето на евалуацискиот прашалник беше забележана појава на некомплетирани одговори на прашањата поради недостатокот на податоци за конкретни аспекти од просторот во домот. Се претпоставува дека овој проблем може да се разреши со подолг престој или повторна посета на местото на снимање, во овој случај во Торонто, со цел да се помине подолго време во домот, да може да се снима просторот на неколку наврати и на тој начин да се забележат повеќе детали. Дополнително на тоа, пожелно е евалуацискиот прашалник да се носи за време на снимањето и, доколку има можност за тоа, да се одговорат прашањата во објектот.

Споредбена анализа помеѓу домови кои биле изградени според европски модел можеби би дала поинакви резултати од наведените во оваа студија поради сличноста во културата и традицијата на станарите кои европските модели се претпоставува дека ги поседуваат. Можеби при такво едно споредбено истражување ќе се увиди дека културата игра значајна улога во местото и ентериерот на домот во којшто лицата со АБ се сместувани и тоа би довело до поинакви резултати.

Покрај употребата на евалуациски прашалник за оценување на карактеристиките на просторот, при снимањето неопходно е да се испита мислењето на станарите кои престојуваат во домот а се во можност да дадат одговор на прашања, или поточно станарите кои се наоѓаат во понизок стадиум на болеста. Покрај мислењето на станарите би било значајно, ако не и најзначајно, мислењето на членовите од персоналот кои имаат директен контакт со станарите и го набљудуваат нивното секојдневно совладување на просторот. Оваа препорака е наведена од причина што за време на снимањето на домовите учеството на член од персоналот кој имаше улога на водич низ просторот, зависеше од тоа кој беше достапен за време на посетата во домот, коешто во VC резултираше во разговор со лице кое не е стручно во областа на нега за лица со АБ и споделените искуства се базираа на личен впечаток наместо на стручно искуство со проблемот. 
Исто така, за поуспешно испитување на интеракцијата помеѓу станарите и ентериерот можеби би било подобро да се евалуираат помали домови, бидејќи кога е поголем домот има повеќе станари, истражувачот е дистанциран од станарите и потешко го дознава нивното мнение за просторот во кој живеат. Мислењето и желбите на станарите може да претставуваат значајна алатка во уредувањето на просторот што би дало придонес во ефективно конечно решение на дизајнот кое ке одговори на потребите на станарите.

\section{Методолошки и концептуални проблеми при истражувањето}

Причината што во РМ нема дом за нега на стари лица кој лицата со АБ ги згрижува во засебен дел од домот или кој има специјални станбени единици за тие лица создава потешкотии во извршувањето на праведна споредбена анализа помеѓу македонските и канадските домови. Покрај тоа, снимањето имаше ограничувања во должината на времето на посетата и голем број содржини не беа достапни за снимање поради присуството на станарите во нив. Ова резултираше во справување со нецелосни податоци за одредени елементи во просторот, кои можеби ќе претставуваат пречка во имплементирање на предложените можни интервенции за прилагодување на просторот во домот МТ за употреба од лица со АБ.

Секое лице со АБ има уникатни и променливи особини поради што е тешко да се одберат најважни карактеристики на болеста за кои треба да се посвети поголемо внимание при дизајнирањето. Тука доаѓа во конфликт потребата од опремување на просторот со сите неопходни безбедносни помагала за спречување на можни повреди кај станарите и истовремениот обид за уредување на простор кој ќе се одликува со домашен изглед. Балансирањето на овие две значајни особини на просторот за лица со АБ ја потврдува потребата од дизајнер кој ќе биде стручен во областа.

Ентериерот во домовите беше оценет со помош на евалуациски прашалник кој не беше објавен во време на снимањето на домовите и беше пополнет откако беше снимен. Прашањата беа одговорени според скиците и прибелешките на авторот, снимените фотографии, нацртот на домот и според сеќавањето на авторот. Сето ова предизвикува ограничувања во веродостојноста и прецизноста на снимањето. Идеалната ситуација би 
била истовремено да се извршат снимањето на домот и оценувањето т.е. одговарањето на евалуациските прашалници да се изведе за време на посетата во домот. 


\section{КОРИСТЕНА ЛИТЕРАТУРА}

AKE. (2010). Dementia-Friendly Design Considerations: Lighting. Regional Geriatric Program of Eastern Ontario.

AKE. (2011). Dementia-Friendly Design Considerations: Noise. Dementia-Friendly Design Considerations.

Alescio-Lautier, B., Michel, B. F., Herrera, C., Elahmadi, a, Chambon, C., Touzet, C., \& Paban, V. (2007). Visual and visuospatial short-term memory in mild cognitive impairment and Alzheimer disease: role of attention. Neuropsychologia, 45(8), 1948-60. doi:10.1016/j.neuropsychologia.2006.04.033

Alzheimer’s Association. (2011). "2011 Alzheimer’s disease facts and figures." Alzheimer's \& Dementia 7(2): 208-244.

Alzheimer's Society. (2012). Living with dementia: Remaining independent. Достапно на: http://www.alzheimers.org.uk/site/scripts/documents.php?categoryID=200349, пристапено на: 14.05.2012

Armstrong, R. A. (2009). Alzheimer's Disease and the Eye. Journal of Optometry, 2(3), 103111. Elsevier. doi:10.3921/joptom.2009.103

Assisted Living Homes. (2010). Glossary of Senior Living Terms. Достапно на: http://www.allassistedlivinghomes.com/assisted-living/assisted-living-glossary.html, пристапено на: 26.06.2012

Bemis-Daugherty, A., \& Delaune, M. F. (2008). Reducing patient falls in inpatient settings. PT Magazine, May, 36-42

Bharathan, T., D. Glodan, et al. (2007). "What do patterns of noise in a teaching hospital and nursing home suggest?" Noise Health 9(35): 31-34.

Biran, Y., Masters, C. L., Barnham, K. J., Bush, A. I. and Adlard, P. A. (2009), Pharmacotherapeutic targets in Alzheimer's disease. Journal of Cellular and Molecular Medicine, 13: abstract. doi: 10.1111/j.1582-4934.2008.00595.x

Bouma, H., Weale, A. R., \& McCreadie, C. (2006). Technological environments for visual independence in later years. Gerontechnology, 5(4), 187-194. doi:10.4017/gt.2006.05.04.001.00

Brawley, E.C. (1997). Designing for Alzheimer's disease: strategies for creating better care environments. New York, NY: Wiley, 238. ISBN: 0471139203. 
Brawley, E.C. (2006). Innovations in design for aging and Alzheimer's disease: Creating Caring Environments. Hoboken, NJ: J. Wiley.

Buzink, S. N., Molenbroek, J. F. M., Haagsman, E. M., De Bruin, R., \& Groothuizen, T. J. J. (2005). Falls in the toilet environment : A study on influential factors. Gerontechnology, 4(1), 16. doi:10.4017/gt.2005.04.01.004.00

Carswell, W., P. J. McCullagh, et al. (2009). "A review of the role of assistive technology for people with dementia in the hours of darkness." Technol Health Care 17(4): 281-304.

Churba, A. E. (2012). Home Adaptations: A Helpful Guide for Caregivers of Those with Alzheimer's and Related Diseases, Booktango.

City of Toronto. (2004). City of Toronto: Accessibility Design Guidelines: 2004. [Online].

Available: http://www.toronto.ca/diversity/pdf/accessibility_design_guidelines.pdf.

[Accessed 04.11.2012].

Davis, S., Byers, S., Nay, R., \& Koch, S. (2009). Guiding design of dementia friendly environments in residential care settings: Considering the living experiences. Dementia, 8(2), 185-203. doi:10.1177/1471301209103250

deLaski-Smith, D. (1998) \#7 - The Bedroom: Suggestions for the Physical Environment. Dementia Care Series Caring Sheets: Thoughts \& Suggestions for Caring. Lansing, Michigan: Michigan Department of Community Health, 7, p.1-10. Available at: http://www.lcc.edu/mhap/CARING/Caring7.2010.pdf [Accessed: 16.05.2013].

Dvorsky, T., \& Pettipas, J. (2005). Elder-Friendly Design Interventions: Acute Care Hospitals Can Learn from Long-Term Care Residences. Implications (Electronic), 02(07): 4. Retrieved from www.informedesign.umn.edu

Falk, H., Wijk, H., \& Persson, L.-O. (2009). The effects of refurbishment on residents' quality of life and wellbeing in two Swedish residential care facilities. Health \& place, 15(3), 687-94. doi:10.1016/j.healthplace.2008.11.004

Ferri, C. P., Prince, M., Brayne, C., Brodaty, H., Frataglioni, L., Ganguli, M.,Hall, K.,Hasegawa, K.,Hendrie, H., Huang, Y., Jorm, A., Mathers, C., Menezes, P. R., Rimmer, E., and Scazufca, M. (2005). Global preva- lence of dementia: a Delphi consen- sus study. Lancet 366, 2112-2117. 
Fisk, M., \& Raynham, P. (2010). Practical Guide to Improving Lighting in Existing Homes Good Practice Guide 5. Social Research (pp. 1-28). London, UK: Thomas Pocklington Trust. Retrieved from http://www.pocklington-trust.org.uk/research/publications/gpg5.htm

Gitlin, L. M., Miller, K. S., \& Boyce, A. (1999). Bathroom modifications for frail elderly renters: Outcomes of a community-based program. Technology and Disability, 10, 141-149.

Gitlin, L. N., \& Chee, Y. K. (2006). Use of Adaptive Equipment in Caring for Persons W ith Dementia at Home. Alzheimer's Care Quarterly, 7(1), 32-40.

Goodman, C., \& Watson, L. (2010). Design guidance for people with dementia and for people with sight loss (pp. 1-8).

Grand, J. H., Caspar, S., \& Macdonald, S. W. (2011). Clinical features and multidisciplinary approaches to dementia care. Journal of multidisciplinary healthcare, 4, pp.134-135. doi:10.2147/JMDH.S17773

Hanson, J. (2001). From “special needs" to "lifestyle choices": articulating the demand for "third age” housing. Urban Morphology, 1-30.

Hill, L.D., Haslam, R., Howarth, P.A., Brooke-Wavell, K.S.F., Sloane, J.E. (2000). Safety of older people on stairs: behavioural factors. Loughborough: Loughborough University. Available at https://dspace.lboro.ac.uk/dspace-jspui/handle/2134/2562

Hodges, L., Bridge, C., \& Chaudhary, K. (2006). Dementia Design Guidelines: Home and Community Care Capital Works Program. Sydney: Home Modification Information Clearinghouse, University of Sydney. Available from http://www.homemods.info

Hoof, J. V., \& Kort, H. S. M. (2009). Supportive living environments: A first concept of a dwelling designed for older adults with dementia. Dementia, 8(2), 293-316. doi:10.1177/1471301209103276

Hoof, J. van, Kort, H.S.M., Duijnstee, M.S.H., Schoutens, A.M.C., Hensen, J.L.M. \& Begemann, S.H.A. (2008). The indoor environment in relation to people with dementia. In StromTejsen, P (Ed.), Proceedings of the $11^{\text {th }}$ International Conference on Indoor Air Quality and Climate, (pp. 8). Copenhagen: Indoor Air.

Hoof, J.V., Kort, H. S. M., van Waarde, H., \& Blom, M. M. (2010). Environmental interventions and the design of homes for older adults with dementia: an overview. American journal of Alzheimer's disease and other dementias, 25(3): 206, doi:10.1177/1533317509358885. 
Housing LIN. (2008). Factsheet 1: (New edition) Extra Care Housing - What is it? [Factsheet]. Retrieved from: http://www.housingcare.org/downloads/kbase/2210.pdf. [Accessed 24.04.2013].

Joule, N., \& Levenson, R. (2009). Housing for People with Sight Loss: A practical guide to improving existing homes. Thomas Pocklington Trust (pp. 1-32). London, UK. Retrieved from http://www.pocklington-trust.org.uk/research/publications/gpg4

Kane, M.N. and Houston-Vega, M.K. (2004). Maximizing content on elders with dementia while teaching multicultural diversity. Journal of Social Work Education, 40(2), pp 285-303.

Kavcic, V., Fernandez, R., Logan, D., \& Duffy, C. J. (2006). Neurophysiological and perceptual correlates of navigational impairment in Alzheimer's disease. Brain : a journal of neurology, 129(Pt 3), 736-46. doi:10.1093/brain/awh727

Manser, M. 1989. The architecture of institutions for demented persons. In Wertheimer, J., Baumann, P., Gaillard, M. and Schwed, P. (eds), Innovative Trends in Psychogeriatrics. Karger, Basle, 22-7.

Marquardt, G. (2011). Wayfinding for People with Dementia : The Role of Architectural Design. Herd, 4(2), 22-41. Retrieved from www.herdjournal.com

Mayo Clinic. 2013. Alzheimer's: Consider options for long-term care. [ONLINE] Available at: http://www.mayoclinic.com/print/alzheimers/AZ00028/METHOD=print. [Accessed 09 May 13].

Ministry of Health and Long-Term Care. (2009). Long-Term Care Design Manual. Ministry of Health and Long-Term Care, Ontario, p.10 (2.2.6). Available at: http://www.health.gov.on.ca/english/providers/program/ltc_redev/renewalstrategy/pdf/home _design_manual.pdf [Accessed 31.12.2012]

Most, E. I. S., Scheltens, P., \& Van Someren, E. J. W. (2010). Prevention of depression and sleep disturbances in elderly with memory-problems by activation of the biological clock with light--a randomized clinical trial. Trials, 11, 19. doi:10.1186/1745-6215-11-19

Namazi KH, DiNatale Johnson B. Dressing independently: a closet modification model for Alzheimer’s disease patients. Am J Alzheimers Dis Other Demen. 1992;7(1): abstract.

National Academy on an Aging Society (1999). Hearing loss: A growing problem that affects quality of life. National Academy on an Aging Society, Number 2, December. Retrieved October 19, 2012, from http://www.agingsociety.org/agingsociety/pdf/hearing.pdf. (cтр.1)

National Institute of Health and Clinical Excellence (2006). Dementia: The NICE-SCIE Guideline on Supporting People with Dementia and Their Carers in Health and Social Care. London, UK: The British Psychological Society and Gaskell. p. 66-68 
Neno, R., Aveyard, B., \& Heath, H. (2007). Older People and Mental Health Nursing: A Handbook of Care. Oxford, UK: Blackwell Publishing Ltd. Chapter 17:211. doi:10.1002/9780470692240

NICE and SCIE (2006) Dementia: Supporting People with Dementia and their Carers in Health and Social Care. NICE clinical guideline 42. Pp.95. Available: www.nice.org.uk/CG42 [NICE guideline]

Regnier, V. (2002) Design for assisted living: Guidelines for housing the physically and mentally frail. New York: John Wiley \& Sons.

Regnier, V., \& Denton, A. (2009). Ten new and emerging trends in residential group living environments. NeuroRehabilitation, 25, 169-188. doi:10.3233/NRE-2009-0514

Riverol, M., \& López, O. L. (2011). Biomarkers in Alzheimer’s disease. Frontiers in neurology, 2(July), 46. doi:10.3389/fneur.2011.00046

Rizzo, M., Anderson, S. W., Dawson, J., Myers, R., \& Ball, K. (2000). Visual attention impairments in Alzheimer's disease. Neurology, 54, abstract.

ROYAL INSTITUTE OF BRITISH ARCHITECTS. (2011). A guide for assisted living: towards LifeHome 21. London, RIBA Publishing.

Salva, A., Roque, M., Rojano, X., Inzitari, M., Andrieu, S., Schiffrin, E. J., Guigoz, Y., et al. (2011). Falls and Risk Factors for Falls in Community-Dwelling Adults With Dementia (NutriAlz Trial). Alzheimer Disease and Associated Disorders, 00(00), 1-7.

Shelton, K., Lee, C. (2010). Comparison of Cognitive Function of Seniors Living in Assisted Living Communities with That of Seniors Living at Home. Alzheimer`s Care Today, 11(4), 245-250. doi:10.1097/ACQ.0b013e3181fbb333

Simmons-Stern, N.R., Budson A.E., Ally, B.A. (2010). Music as a memory enhancer in patients with Alzheimer's disease Neuropsychologia, 48 (10), abstract. http://www.sciencedirect.com/science/article/pii/S002839321000179X

Sloane, D. P., \& Sloane, P.D., Noell-Waggoner, E., Hickman, S., Mitchell, M., Williams, C.S., Preisser, J.S., Barrick, A.L., Zimmerman, S., Brawley, E. (2005). Implementing a Lighting Intervention in Public Areas of Long-term Care Facilities: Lessons Learned. Alzheimer's Care Quarterly, 6(4), 280-293. 
Tales, A., Haworth, J., Nelson, S., Snowden, R. J.,\&Wilcock, G. (2005). Abnor- mal visual search in mild cognitive impairment and Alzheimer's disease. Neurocase, 11, 80-84.

Tamura T., Nakajima K., Nambu M., Nakamura K., Yonemitsu S., Itoh A., Higashi Y., Fujimoto T., Uno H. (2001). Baby dolls as therapeutic tools for severe dementia patients. Gerontechnology 1(2):111-118

Taylor, J., 2005. Hot Technologies: Advanced Lighting Technologies Enhance Resident Care, Long-Term Living, [online] Available at: http://www.ltlmagazine.com/article/hottechnologies-advanced-lighting-technologies-enhance-resident-care [Accessed: 29/04/2013].

The Assisted Living Federation of America. (2009). Assisted Living Information. Достапно на: http://www.alfa.org/alfa/Assisted_Living_Information.asp, пристапено на: 20.10.2012

Tofle, R. B., Schwarz, B. Yoon, S-Y. and Max-Royale, A. (2004). Color in Healthcare Environments. Coalition for Health Environments Research (CHER).

Toronto Dementia Network. 2013. Services - Long Term Care Homes. [ONLINE] Available at: http://www.dementiatoronto.org/0802.asp. [Accessed 02 May 13].

Torrington, J. (2007). Evaluating quality of life in residential care buildings. Building Research \& Information, 35(5), 514 -528. doi:10.1080/09613210701318102

Torrington, J. M., \& Tregenza, P. R. (2007). Lighting for people with dementia. Lighting Research and Technology, 39(1), 81-97. doi:10.1177/1365782806074484

United Nations (2009). World Population Ageing 2009. New York: UN Department of Economics and Social Affairs, Population Division.

Utton, D. (2009). The design of housing for people with dementia. Journal of Care Services Management, 3(4), 380-390.

Van Hoof, J., Kort, H. S. M., Van Waarde, H., \& Blom, M. M. (2010). Environmental interventions and the design of homes for older adults with dementia: an overview. American journal of Alzheimer's disease and other dementias, 25(3): 207, 225. doi:10.1177/1533317509358885

Verbeek, H. (2011). Redesigning dementia care: An evaluation of small-scale, homelike care environments. CAPHRI. CAPHRI, the School for Public Health and Primary Care, Maastricht University.

Walker, personal communication, August 12, 2011 
Wang, Z., \& Shepley, M. M. (2008). Site-Level Environmental Support of Active Behavior and Fall Prevention for Seniors. Seniors Housing \& Care Journal, 16(1), 97-122.

Weinstein, M., and Amsel, L. (1986). Hearing Loss and Senile Dementia in the Institutional Elderly. Clinical Gerontologist, 4, 3-15.

Williams JW, Plassman BL, Burke J, Holsinger T, Benjamin S. (2010). Preventing Alzheimer's Disease and Cognitive Decline. Evidence Report/Technology Assessment No. 193. (Prepared by the Duke Evidence-based Practice Center under Contract No. HHSA 2902007-10066-I.) AHRQ Publication No. 10-E005. Rockville, MD: Agency for Healthcare Research and Quality.

Zeisel, J. (2005). Environment, Neuroscience, and Alzheimer's Disease. Alzheimer's Care Quarterly, 6(4), 273-279.

Министерство за труд и социјална политика. (2010). Правилник за нормативите и стандардите за основање и започнување со работа на установи за социјална заштита за стари лица. Службен весник на Република Македонија, бр.25/10, стр. 22. Преземено од: http://www.slvesnik.com.mk/Issues/E622D1B821B0454881335F6A52A82BF7.pdf на 14.12.2012.

Талеска, П. (2012). Дом за стари - бизнис за млади. Нова Македонија, 22485 - 1 јануари 2012. Достапно на: http://www.novamakedonija.com.mk/NewsDetal.asp?vest=12112935164\&id=9\&prilog=0 \&setIzdanie=22485. Пристапено на: 21.06.2012

Тасев, М. и Здравковска, Ж. (2011). Нема место ни за лек во старските домови: Старите предолго чекаат топол дом. [online] Available at:

http://www.dnevnik.com.mk/default.asp?ItemID=BCF38ABA30483D4ABF468DD8F6AD A707 [Accessed 22 January 2013].

Центар за истражување и креирање политики. (2009). Повеќе нега во примарното здравство! Повеке цеентри за нега во заедниците! Кратка анализа бр.18. Центар за истражување и креирање политики, Скопје, Македонија. Преземено: www.crpm.org.mk/wp-content/uploads/2012/03/Poveke-negaEN.pdf, пристапено на: 14.05.2012. 


\section{ПРИЛОЗИ}

\section{П.1 Одговорен евалуациски прашалник за домот Humber Heights}

\section{evolve}

Evaluation of Older People's Living Environments

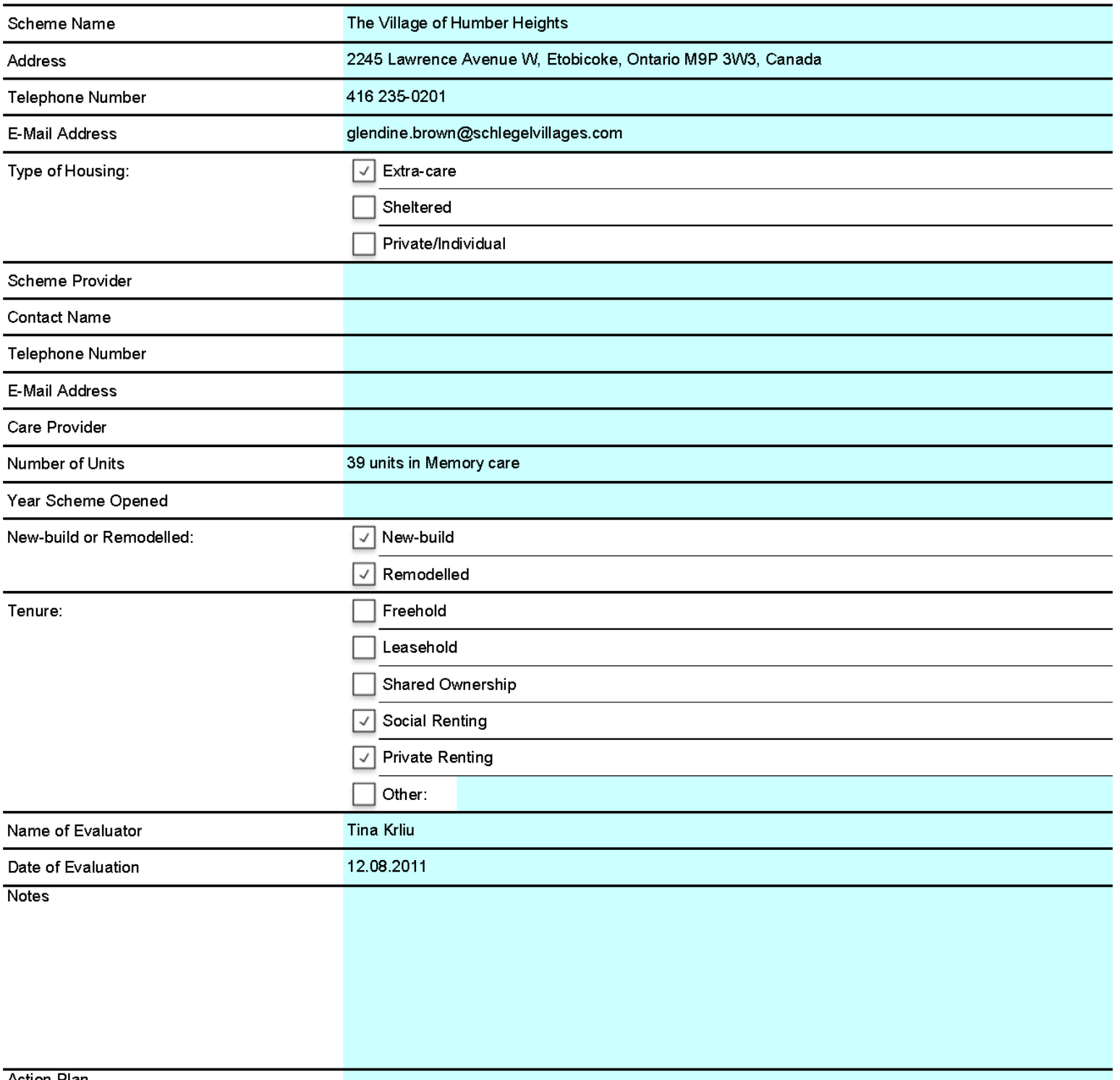




\begin{tabular}{|c|c|c|c|c|}
\hline & 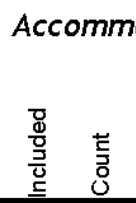 & odation schedu & 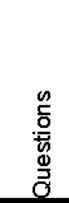 & 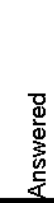 \\
\hline E01 & \multicolumn{2}{|l|}{ Living Unit } & 301 & 289 \\
\hline & \multicolumn{2}{|r|}{ Generic } & 17 & 17 \\
\hline & $\square$ & Entrance & 36 & 36 \\
\hline & $\square$ & Alternative entrance & 0 & 0 \\
\hline & $\nabla$ & Hall & 32 & 32 \\
\hline & $\nabla$ & Lounge & 56 & 52 \\
\hline & $\square$ & Kitchen & 0 & 0 \\
\hline & $\nabla$ & Double bedroom & 64 & 63 \\
\hline & $\square$ & Single bedroom & 0 & 0 \\
\hline & $\square$ & Bathroom & 81 & 74 \\
\hline & $\square$ & Cupboards & 0 & 0 \\
\hline & $\square$ & General items & 7 & 7 \\
\hline & $\square$ & Assistive technology & 8 & 8 \\
\hline E02 & Communal & Facilities & 275 & 239 \\
\hline & & Generic & 18 & 18 \\
\hline & $\checkmark$ No. & Main lounge & 59 & 59 \\
\hline
\end{tabular}




\begin{tabular}{|c|c|c|c|c|c|}
\hline & $\square$ & No. & Dining room & 0 & 0 \\
\hline & $\checkmark$ & No. & Small lounge & 50 & 18 \\
\hline & $\square$ & No. & Bar & 0 & 0 \\
\hline & $\square$ & No. & Activity room & 83 & 82 \\
\hline & $\square$ & No. & IT suite & 0 & 0 \\
\hline & $\square$ & No. & Library & 0 & 0 \\
\hline & $\square$ & No. & Conservatory & 0 & 0 \\
\hline & $\square$ & No. & Garden & 0 & 0 \\
\hline & $\square$ & No. & Assisted bathroom & 65 & 62 \\
\hline & $\square$ & No. & wC & 0 & 0 \\
\hline & $\square$ & No. & Clinic & 0 & 0 \\
\hline & $\square$ & No. & Therapy room & 0 & 0 \\
\hline & $\square$ & No. & Gym & 0 & 0 \\
\hline & $\square$ & No. & Hairdresser & 0 & 0 \\
\hline & $\square$ & No. & Shop & 0 & 0 \\
\hline & $\square$ & No. & Laundry & 0 & 0 \\
\hline & $\square$ & No. & Storage & 0 & 0 \\
\hline & $\square$ & No. & Refuse store & 0 & 0 \\
\hline E03 & \multicolumn{3}{|c|}{ Circulation } & 81 & 37 \\
\hline
\end{tabular}




\begin{tabular}{|c|c|c|c|c|}
\hline & & Generic & 10 & 9 \\
\hline & $\nabla$ & General circulation & 12 & 12 \\
\hline & $\square$ & Main entrance & 0 & 0 \\
\hline & $\square$ & Foyer & 0 & 0 \\
\hline & $\square$ & Internal & 59 & 16 \\
\hline & $\square$ & External covered & 0 & 0 \\
\hline & $\square$ & External uncovered & 0 & 0 \\
\hline & $\square$ & Stairs & 0 & 0 \\
\hline & $\square$ & Lift & 0 & 0 \\
\hline E04 & Stafi & Services & 0 & 0 \\
\hline & & Generic & 0 & 0 \\
\hline & $\square$ & Scheme manager's office & 0 & c \\
\hline & $\square$ & Care manager's office & 0 & 0 \\
\hline & $\square$ & Staff facilities & 0 & c \\
\hline & $\square$ & Catering kitchen & 0 & 0 \\
\hline E05 & Site & ocation & 0 & 0 \\
\hline & $\square$ & Scheme location & 0 & 0 \\
\hline & $\square$ & Scheme boundary & 0 & 0 \\
\hline & $\square$ & Entrance & 0 & c \\
\hline & $\square$ & Parking & 0 & 0 \\
\hline & Tota & & 657 & 565 \\
\hline
\end{tabular}


Control sheet for results AMEND

domain weighting

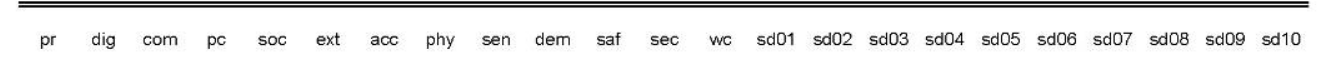

Total

Living Unit

Communal Facilities

Circulation

Staff and Services

Site and Location

domain count yes

pr dig com pc soc ext acc phy sen dem saf sec wc

pr dig com pc soc ext acc phy sen dem saf sec wc pr

\begin{tabular}{|c|c|c|c|c|c|c|c|c|c|c|c|c|c|c|c|c|c|c|c|c|c|c|c|c|c|c|}
\hline 33 & 8 & 34 & 16 & 6 & 4 & 42 & 43 & 103 & 68 & 35 & 4 & 7 & 6 & 4 & 5 & 4 & 0 & 0 & 3 & 6 & 13 & 6 & 1 & 1 & & 0 \\
\hline 21 & 6 & 20 & 9 & 1 & 1 & 20 & 20 & 51 & 32 & 14 & 3 & 1 & 4 & 3 & 3 & 3 & 0 & 0 & 2 & 3 & 9 & 5 & 1 & 1 & & 0 \\
\hline 11 & 2 & 14 & 7 & 5 & 3 & 19 & 21 & 48 & 31 & 18 & 1 & 6 & 2 & 1 & 2 & 1 & 0 & 0 & 1 & 3 & 3 & 0 & 0 & 0 & & 0 \\
\hline 1 & 0 & 0 & 0 & 0 & 0 & 3 & 2 & 4 & 5 & 3 & 0 & 0 & 0 & 0 & 0 & 0 & 0 & 0 & 0 & 0 & 1 & 1 & 0 & 0 & & 0 \\
\hline 0 & 0 & 0 & 0 & 0 & 0 & 0 & 0 & 0 & 0 & 0 & 0 & 0 & 0 & 0 & 0 & 0 & 0 & 0 & 0 & 0 & 0 & 0 & 0 & 0 & & 0 \\
\hline 0 & 0 & 0 & 0 & 0 & 0 & 0 & 0 & 0 & 0 & 0 & 0 & 0 & 0 & 0 & 0 & 0 & 0 & 0 & 0 & 0 & 0 & 0 & 0 & 0 & & 0 \\
\hline
\end{tabular}

in count not in use

domain count $n / a$

\begin{tabular}{|c|c|c|c|c|c|c|c|c|c|c|c|c|c|c|c|c|c|c|c|c|c|c|c|c|c|c|c|}
\hline dig & com & $\mathrm{pc}$ & soc & & ext & acc & phy & sen & dem & $n$ se & af & $\mathrm{sec}$ & wc & $\mathrm{pr}$ & dig & com & $\mathrm{pc}$ & soc & & ext & acc & phy & sen & dem & saf & $\mathrm{sec}$ & $w c$ \\
\hline 0 & 0 & 0 & 0 & 0 & 0 & 0 & 0 & & 0 & 0 & 0 & 0 & 0 & 17 & 6 & 32 & 4 & & 1 & 2 & 22 & 14 & 42 & 20 & 31 & 3 & 3 \\
\hline 0 & 0 & 0 & 0 & 0 & 0 & 0 & 0 & & 0 & 0 & 0 & 0 & 00 & 7 & 1 & 15 & 0 & & 0 & 0 & 8 & 3 & 16 & 4 & 5 & 0 & 2 \\
\hline 0 & 0 & 0 & 0 & 0 & 0 & 0 & 0 & & 0 & 0 & 0 & 0 & 00 & 0 & 0 & 0 & 0 & & 0 & 0 & 0 & 0 & 0 & 0 & 0 & 0 & 0 \\
\hline
\end{tabular}




\section{evolve}

Results

The Village of Humber Heights

Display chart for Creulation

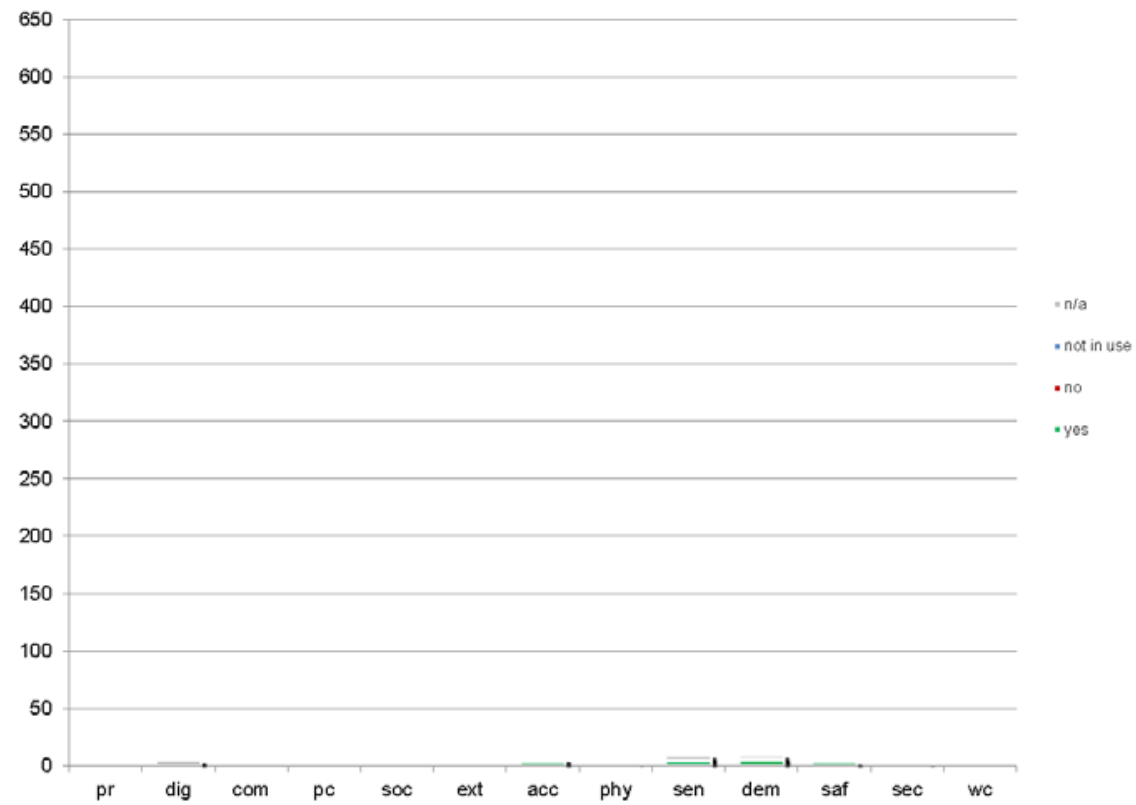

\begin{tabular}{|c|c|c|c|c|c|c|c|c|c|c|c|c|c|}
\hline $\mathrm{n} / \mathrm{a}$ & 0 & 5 & 1 & 0 & 0 & 0 & 3 & 0 & 4 & 3 & 1 & 2 & 0 \\
\hline not in use & 0 & 0 & 0 & 0 & 0 & 0 & 0 & 0 & 0 & 0 & 0 & 0 & 0 \\
\hline no & 0 & 0 & 0 & 0 & 0 & 0 & 0 & 0 & 1 & 1 & 0 & 0 & 0 \\
\hline yes & 1 & 0 & 0 & 0 & 0 & 0 & 3 & 2 & 4 & 5 & 3 & 0 & 0 \\
\hline
\end{tabular}




\begin{tabular}{|c|c|c|c|c|}
\hline Ho. ITEM & yes & no & $\begin{array}{l}\text { not in } \\
\text { use }\end{array}$ & n/a \\
\hline \multicolumn{5}{|l|}{ Building Elements - Doors (Does not apply to Living Unit entrance) } \\
\hline 1 The colour of doors contrasts with the colour of the surrounding walls & $\mathrm{O}$ & ○ & $\mathrm{O}$ & $\mathrm{O}$ \\
\hline 2 Doors have a non-reflective satin or matt finish & O & 0 & 0 & 0 \\
\hline 3 The colour of door handles contrasts with the colour of doors & ( & 0 & 0 & $\mathrm{O}$ \\
\hline 4 Door furniture has a non-reflective finish & 0 & $\mathrm{O}$ & $\mathrm{O}$ & $\mathrm{O}$ \\
\hline 5 Door handles are easy to operate ( $D$-shape, L-shape, lever handle) & (0) & 0 & 0 & 0 \\
\hline 6 Doors open with minimum pressure & ( ) & 0 & 0 & 0 \\
\hline 7 Thresholds are flush with general floor level & ○ & $\mathrm{O}$ & $\mathrm{O}$ & $\mathrm{O}$ \\
\hline 8 Doors have a dear opening more than $800 \mathrm{~mm}$ wide & O & 0 & 0 & 0 \\
\hline
\end{tabular}

Environmental Design

\begin{tabular}{|c|c|c|c|c|}
\hline 9 Windows have locks & (9) & $\mathrm{O}$ & O & $\mathrm{O}$ \\
\hline $\begin{array}{l}10 \text { Windows can be opened by easily operated controls fixed more than } 750 \mathrm{~mm} \text { and less than } 1200 \mathrm{~mm} \text { from } \\
\text { floor level }\end{array}$ & $\mathrm{O}$ & $\mathrm{O}$ & $\mathrm{O}$ & ○ \\
\hline 11 Fitted lights closest to the windows can be switched on and off independently of lights furthest from windows & ○ & 0 & 0 & O \\
\hline 12 Light bulbs can be replaced from floor level & $\mathrm{O}$ & 0 & $\mathrm{O}$ & O \\
\hline 13 Living units have a radiat or or under floor heating & $\mathrm{O}$ & $\mathrm{O}$ & 0 & O \\
\hline 14 The radiator or underfloor heating has a low surface temperature & 0 & 0 & 0 & O \\
\hline 15 Room s or radiators have an individual thermostatic temperature control & $\mathrm{O}$ & $\mathrm{O}$ & $\mathrm{O}$ & 0 \\
\hline
\end{tabular}

Services and Systems

\begin{tabular}{l|ll}
\hline 16 Electrical sockets are more than $450 \mathrm{~mm}$ and less than $1200 \mathrm{~mm}$ from floor level & 0 & 0 \\
\hline 17 Light switches are more than $1000 \mathrm{~mm}$ and less than $1200 \mathrm{~mm}$ from floor level & 0 & 0 \\
\hline
\end{tabular}




\section{evolve}

Entrance

Alternative Entrance

\begin{tabular}{|c|c|c|c|c|}
\hline No. ITEM & yes & no & $\begin{array}{l}\text { not in } \\
\text { use }\end{array}$ & $\mathbf{n} / \mathbf{a}$ \\
\hline \multicolumn{5}{|l|}{ Layout } \\
\hline 1 The living unit entrance is in a visible position & 0 & $\mathrm{O}$ & $\mathrm{O}$ & $\mathrm{O}$ \\
\hline 2 The living unit entrance is in a recognisable position [Glossary 1.01] & $\mathrm{O}$ & (-) & $\mathrm{O}$ & $\mathrm{O}$ \\
\hline 3 The living unit entrance is set back from the main travel route providing a space which an be personalised & (c) & $\mathrm{O}$ & $\mathrm{O}$ & $\mathrm{O}$ \\
\hline 4 There is space around the living unit entrance for plants or flowers & (c) & 0 & 0 & 0 \\
\hline $\begin{array}{l}5 \text { The distance between the opening edge of the front door and any adjacent wall is more than } 300 \mathrm{~mm} \\
\text { [Glossary 1.02] }\end{array}$ & $\mathrm{O}$ & $\mathrm{O}$ & $\mathrm{O}$ & () \\
\hline
\end{tabular}

Building Elements

\begin{tabular}{|c|c|c|c|c|}
\hline 6 The colour of the front door on the outside contrasts with the colour of the surrounding walls & ( & $\mathrm{O}$ & $\mathrm{O}$ & O \\
\hline 7 The front door has a non-reflective satin or matt finish & ( & $\mathrm{O}$ & $\mathrm{O}$ & $\mathrm{O}$ \\
\hline 8 The numbering on the front door is raised & (2) & $\mathrm{O}$ & $\mathrm{O}$ & O \\
\hline 9 The colour of the door handle to the front door contrasts with the colour and/or tone of the door & (-) & $\mathrm{O}$ & $\mathrm{O}$ & $\mathrm{O}$ \\
\hline 10 The door handle on the front door has a non-reflective finish & $\mathrm{O}$ & ( & O & O \\
\hline 11 The door handle on the front door is easy to operate (D-shape, L-shape, lever handle) & ( & $\mathrm{O}$ & $\mathrm{O}$ & $\mathrm{O}$ \\
\hline 12 The front door locking system is easy to operate (e.g. fob) [Glossary 2.01] & $\mathrm{O}$ & $\mathrm{O}$ & $\mathrm{O}$ & ○ \\
\hline 13 The front door lock is positioned above the door handle & $\mathrm{O}$ & $\mathrm{O}$ & $\mathrm{O}$ & - \\
\hline 14 The front door opens with minimum pressure or is power-assisted [Glossary 2.04] & () & $\mathrm{O}$ & $\mathrm{O}$ & $\mathrm{O}$ \\
\hline 15 The front door closers incorporate a delay and final damping [Glossary 2.05] & $\mathrm{O}$ & $\mathrm{O}$ & $\mathrm{O}$ & - \\
\hline 16 The front door closers are connected to the fire alarm [Glossary 2.06] & $\mathrm{O}$ & 0 & $\mathrm{O}$ & ( \\
\hline 17 The entrance threshold is flush with general floor level & ( & 0 & $\mathrm{O}$ & O \\
\hline 18 The entrance mat to the living unit is recessed & $\mathrm{O}$ & $\mathrm{O}$ & $\mathrm{O}$ & ○ \\
\hline 19 The front door has a letter box & 0 & 0 & $\mathrm{O}$ & $\mathrm{O}$ \\
\hline
\end{tabular}




\begin{tabular}{|c|c|c|c|c|c|}
\hline & The letter box is fitted with a cage big enough to hold A4 size letters and packages & 0 & $\mathrm{O}$ & $\mathrm{O}$ & ( ) \\
\hline 21 & The letter box is more than $800 \mathrm{~mm}$ and less than $1200 \mathrm{~mm}$ from floor level & $\mathrm{O}$ & $\mathrm{O}$ & $\mathrm{O}$ & ( \\
\hline & The front door has a door bell & $\mathrm{O}$ & ( & $\mathrm{O}$ & $\mathrm{O}$ \\
\hline 23 & The door bell is illuminated & $\mathrm{O}$ & $\mathrm{O}$ & $\mathrm{O}$ & ( \\
\hline & The front door has an eyehole & $\mathrm{O}$ & ( & $\mathrm{O}$ & $\mathrm{O}$ \\
\hline 25 & The eyehole is more than $1050 \mathrm{~mm}$ and less than $1500 \mathrm{~mm}$ from floor level & $\mathrm{O}$ & $\mathrm{O}$ & $\mathrm{O}$ & ( \\
\hline & $\begin{array}{l}\text { The front door has an eyehole suitable for a wheelchair user at more than } 1150 \mathrm{~mm} \text { and less than } 1250 \mathrm{~mm} \\
\text { from floor level }\end{array}$ & $\mathrm{O}$ & $\mathrm{O}$ & $\mathrm{O}$ & ○ \\
\hline 27 & The front door opening is more than $800 \mathrm{~mm}$ wide & - & $\mathrm{O}$ & $\mathrm{O}$ & $\mathrm{O}$ \\
\hline
\end{tabular}

Fittings

\begin{tabular}{l|ll}
\hline 28 Shelving is provided outside the living unit entrance & 0 & 0 \\
\hline 29 The area around the living unit entrance has been personalised & 0 & 0 \\
\hline
\end{tabular}

Environmental Design

\begin{tabular}{l|c}
\hline 30 The living unit entrance is illuminated day and night & 0 \\
\hline 31 The living unit entrance is illuminated with down lighters & 0 \\
\hline 32 The light fittings conceal the light source from view & 0 \\
\hline 33 The living unit entrance electric light illuminance is more than 300 lux & 0 \\
\hline
\end{tabular}

Services and Systems

\begin{tabular}{l|c}
\hline 34 The scheme front door has an entry phone system & 0 \\
\hline Finishes & 0 \\
\hline 35 The external floor finishes around the living unit entrance are non-slip & 0 \\
\hline 36 The internal floor finishes around the living unit entrance are non-slip & 0 \\
\hline
\end{tabular}




\begin{tabular}{|c|c|c|c|c|}
\hline Hall & & & & unge » \\
\hline Ho. ITEM & yes & no & $\begin{array}{l}\text { not in } \\
\text { use }\end{array}$ & nia \\
\hline \multicolumn{5}{|l|}{ Layout } \\
\hline 1 There is space inside the hallway to stand a wheelchairizimm er fram etrolley [Glossary 1.03 ] & 0 & 0 & 0 & $\odot$ \\
\hline 2 There is general storage space off the hallway & (-) & 0 & 0 & 0 \\
\hline 3 There is space inside the hallway for a wheelchair turning circle more than $1500 \mathrm{~mm}$ [Glossary 1.04 ] & 0 & 0 & O & ○ \\
\hline \multicolumn{5}{|l|}{ Fittings } \\
\hline 4 There is a shelf inside the hallway to rest objects on & O & ○ & 0 & O \\
\hline 5 The hallway has fitted coat hooks more than $1050 \mathrm{~mm}$ and less than $1400 \mathrm{~mm}$ from floor level & 0 & 0 & 0 & 0 \\
\hline
\end{tabular}

\begin{tabular}{|c|c|c|c|c|}
\hline \multicolumn{5}{|l|}{ Environmental Design } \\
\hline 6 The hallway has natural light & 0 & $\mathrm{O}$ & O & O \\
\hline 7 The hallway receives sunlight in the moming or in the afternoon & 0 & $\mathrm{O}$ & O & $\mathrm{O}$ \\
\hline 8 The hallway receives sunlight in the moming and afternoon & 0 & 0 & 0 & ○ \\
\hline 9 The hallway windo whas a viewo the open sky & 0 & 0 & 0 & ○ \\
\hline 10 There are shading devices on $S, E, W$ facing windows & O & O & 0 & ○ \\
\hline 11 The shading devices can be operated by people using the hall way & 0 & 0 & 0 & ○ \\
\hline 12 The shading devices fully cover the windo w(s) & 0 & 0 & 0 & $\odot$ \\
\hline 13 The hallwway has natural ventilation & 0 & 0 & 0 & ○ \\
\hline 14 The hall way windo ws have looks & 0 & O & 0 & 0 \\
\hline $\begin{array}{l}15 \text { The hall livay windowcan be opened by easily operated controls fixed more than } 750 \mathrm{~mm} \text { and less than } \\
1200 \mathrm{~mm} \text { from finished floor level }\end{array}$ & O & O & O & $\odot$ \\
\hline 16 The hallway light fittings conceal the light source from view & () & O & 0 & O \\
\hline 17 The hallway light can be switched on and off from either end of the hall way & O & O & 0 & ○ \\
\hline 18 The hallway has em ergency lighting [Glossary 4.01$]$ & 0 & 0 & 0 & ○ \\
\hline 19 The hallway entrance electric light illuminance is more than 200 lux & 0 & 0 & 0 & ○ \\
\hline 20 The hallway has a radiat or or underfloor heating & 0 & 0 & 0 & ○ \\
\hline 21 The radiator or underfloor heating has low surface tem perature & 0 & 0 & 0 & ○ \\
\hline 22 The room or the radiator has an individual them ostatic temperature control & $\mathrm{O}$ & O & 0 & $\odot$ \\
\hline 23 There are no wall-mounted eledric heaters present & ○ & O & 0 & O \\
\hline 24 There are no portable electric heaters present & () & 0 & 0 & O \\
\hline 25 The hallway background temperature is more than 21 and less than $23 \mathrm{deg} C$ & 0 & 0 & 0 & ○ \\
\hline
\end{tabular}

\section{Services and Systems}

26 There is an alarm call in the hallway

$\circ 000$




\begin{tabular}{|c|c|c|c|c|}
\hline 27 The hallway has a sm oke detector & $\mathrm{O}$ & $\mathrm{O}$ & $\mathrm{O}$ & ○ \\
\hline 28 The hallway is provided with plug sockets & 0 & 0 & 0 & $\odot$ \\
\hline 29 The hallway plug sockets are more than $450 \mathrm{~mm}$ and less than $1200 \mathrm{~mm}$ from finished floor level & O & O & O & ○ \\
\hline 30 The hallway light switches are visible in the dark & 0 & Q & 0 & Q \\
\hline 31 The hallway light switches are more than $1000 \mathrm{~m} m$ and less than $1200 \mathrm{~mm}$ from finished floor level & 0 & O & O & 0 \\
\hline \multicolumn{5}{|l|}{ Finishes } \\
\hline 32 The hallway is painted in a light colour with a matt finish & $\odot$ & O & O & 0 \\
\hline
\end{tabular}




\section{evolve}

Lounge

Ktchen »

\begin{tabular}{|c|c|c|c|c|}
\hline Ho. ITEM & yes & no & $\begin{array}{l}\text { not in } \\
\text { use }\end{array}$ & nia \\
\hline \multicolumn{5}{|l|}{ Layout } \\
\hline 1 There is space for a bookcase, TV, CDinusic player and a computer desk in the lounge & 0 & 0 & 0 & 0 \\
\hline $\begin{array}{l}2 \text { There is spaos in the lounge for a minimum of four people to sit down within a } 3.5 \mathrm{~m} \text { diameter without } \\
\text { rearranging furniture }\end{array}$ & $\odot$ & O & 0 & O \\
\hline $\begin{array}{l}\text { There is space in the lounge for a sitting area with com fortable chairs near the TV and telephone within } \\
\text { reach }\end{array}$ & ○ & 0 & 0 & O \\
\hline 4 There is space inside the lounge entranoe for a wheelchair tuming circle more than $1500 \mathrm{~mm}$ in diam eter & $\circ$ & 0 & 0 & 0 \\
\hline $\begin{array}{l}\text { The distance between the opening edge of the door and any adjacent wall is more than } 300 \mathrm{~mm} \text { (Do not } \\
\text { score this titem "Lounge combined with Halli) }\end{array}$ & $\mathrm{O}$ & O & $\mathrm{O}$ & ○ \\
\hline
\end{tabular}

Building Elements - Door (Do not score these tems if Lounge combined with Hall)

\begin{tabular}{l|llll}
\hline 6 The colour of the lounge door contrasts with the colour ofthe surrounding walls [Glossary 2.02] & 0 & 0 & 0 \\
\hline 7 The lounge door has a non-reflective satin or m matt finish & 0 & 0 & 0 \\
\hline 8 The colour of the lounge door handle contrasts with the colour ofthe lounge door [Glossary 2.03] & 0 & 0 & 0 \\
\hline 9 The door furniture on the lounge door has a non reflective finish & 0 & 0 & 0 \\
\hline 10 The door handle on the lounge door is easyto operate (D-shape, L-shape, lever handle) & 0 & 0 & 0 \\
\hline 11 The lounge door opens with minimum pressure & 0 & 0 & 0 \\
\hline 12 The lounge threshold is flush with general floor level & 0 & 0 & 0 & 0 \\
\hline 13 The lounge door has a dear opening more than 800mm wide & 0 & 0 & 0 \\
\hline
\end{tabular}

\begin{tabular}{|c|c|c|c|c|}
\hline \multicolumn{5}{|l|}{ Building Elements - BalconyNeranda } \\
\hline 14 The lounge leads onto a balcony/veranda & 0 & $\odot$ & 0 & 0 \\
\hline 15 The threshold betwe en the lounge and balcony yveranda is fiush & 0 & 0 & 0 & o \\
\hline 16 The bal oonyweranda has protedion to prevent people from falling & 0 & 0 & 0 & 0 \\
\hline 17 If the living unit is on the ground flloor, the patiojveranda is physically distinct from the surrounding areas & 0 & 0 & 0 & 0 \\
\hline 18 The depth of the balconyiveranda is more than $1800 \mathrm{~m} m$ & $\mathrm{O}$ & O & 0 & $\mathrm{O}$ \\
\hline
\end{tabular}

\begin{tabular}{|c|c|c|c|c|}
\hline \multicolumn{5}{|l|}{ Environmental Design } \\
\hline 19 The lounge has natural light & ○ & O & O & O \\
\hline 20 The lounge receives sunlight in the morning or in the attemoon [Glossary 4.02 ] & ○ & 0 & 0 & 0 \\
\hline 21 The lounge reoeives sunlight in the morning and atternoon [Glossary 4.03] & 0 & 0 & 0 & $\circ$ \\
\hline $22 S, E, W$ facing windows are free from obstruction to direct sunlight [Glossary 4.04] & ( ) & o & O & O \\
\hline 23 The lounge window(s) has a view of the open sky [Glossary 4.05 ] & - & 0 & 0 & 0 \\
\hline 24 The lounge window(s) overlooks outdoor spaces where there is hum an adtivity [Glossary 4.06] & 0 & 0 & 0 & ( \\
\hline 25 The view from the lounge window $\infty$ onsists of near and distant features of interest [Glossary 4.07] & 0 & 0 & 0 & ○ \\
\hline 26 The view trom the lounge window oonsists of natural features [Glossary 4.08 ] & 0 & 0 & 0 & 0 \\
\hline
\end{tabular}




\begin{tabular}{|c|c|c|c|c|}
\hline 27 The vew trom the lounge window is tree trom obstructions, e.g. a blank wall [Glossary 4.09] & $\odot$ & O & O & o \\
\hline 28 The sill height is less than $600 \mathrm{~mm}$ above floor level & ○ & 0 & ○ & o \\
\hline 29 The lounge has a daylight factor more than 2 & 0 & 0 & ○ & $\odot$ \\
\hline 30 There are shading devices for $S, E, W$ facing windows [Glossary 4.10 ] & ○ & 0 & O & ○ \\
\hline 31 The shading devices can be operated by people using the lounge & 0 & 0 & o & o \\
\hline 32 The shading devices tully cover the window(s) & () & 0 & 0 & 0 \\
\hline 33 The lounge has natural ventilation & 0 & 0 & o & o \\
\hline 34 The lounge window(s) has a lock & $\circ$ & 0 & O & 0 \\
\hline $\begin{array}{l}35 \text { The lounge window can be opened by easily operated controls fixed more than } 750 \mathrm{~mm} \text { and less than } \\
1200 \mathrm{~m} \mathrm{~m} \text { from floor level }\end{array}$ & Q & 0 & 0 & 0 \\
\hline $\begin{array}{l}36 \text { Fitted lights closest to the windows can be switched on and off independently of lights furthest from } \\
\text { windows }\end{array}$ & 0 & 0 & 0 & 0 \\
\hline 37 The artificial light in the lounge is mell distributed with no areas of deep shadow & 0 & 0 & O & 0 \\
\hline 38 The lounge light fittings conceal the light source from vew [Glossary 4.11] & 0 & 0 & O & 0 \\
\hline 39 The lounge light bulbs can be replaced from floor level & 0 & 0 & 0 & ○ \\
\hline 40 The lounge lighting can be dirmmed & O & 0 & 0 & 0 \\
\hline 41 The electric light illuminanos is more than 200 lux & 0 & 0 & 0 & ○ \\
\hline 42 The lounge has a radiator or under floor heating & 0 & 0 & 0 & ○ \\
\hline 43 The racliator or underfloor heasting has a low surface temperature [Glossary 4.12$]$ & 0 & 0 & 0 & ○ \\
\hline 44 The room or radiator has an individual them ostatic temperature control [Qlossary 4.13] & 0 & 0 & 0 & ○ \\
\hline 45 There are no mall-m ounted electric heaters present [Glossary 4.14] & $\circ$ & 0 & O & 0 \\
\hline 46 There are no portable electric heaters present & $\circ$ & 0 & 0 & $\mathrm{O}$ \\
\hline 47 The lounge background tem perature is more than 21 and less than $23 \mathrm{deg} C$ & 0 & 0 & 0 & 0 \\
\hline
\end{tabular}

\begin{tabular}{|c|c|c|c|c|}
\hline \multicolumn{5}{|l|}{ Services and Systems } \\
\hline 48 The lounge has an alarm call & ( & o & o & o \\
\hline 49 The lounge has a smoke or heat detector & - & 0 & 0 & 0 \\
\hline 50 The lounge's telephone point(s) is adjacent to an electrical socket & 0 & 0 & 0 & ○ \\
\hline 51 The lounge's TV aerial poirt(s) is adjacent to an electrical socket & 0 & 0 & 0 & 0 \\
\hline 52 The electrical sockets can be reached without having to move the lounge furniture & 0 & ० & ० & ○ \\
\hline 53 The lounge's electrical sockets are more than $450 \mathrm{~mm}$ and less than $1200 \mathrm{~mm}$ from floor level & ○ & 0 & 0 & O \\
\hline 54 The lounge light switches are visible in the dark & 0 & 0 & 0 & ○ \\
\hline 55 The lounge light switches are more than $1000 \mathrm{~mm}$ and less than $1200 \mathrm{~mm}$ from floor level & 0 & 0 & 0 & 0 \\
\hline
\end{tabular}

Finishes

56 The lounge is decorated in a light colour with a matt finish

$\circ \circ \circ 0$ 


\begin{tabular}{|c|c|c|c|c|}
\hline Double bedroom & \multicolumn{4}{|c|}{ Single Bedroom $*$} \\
\hline Ho. ITEM & yes & no & $\begin{array}{l}\text { not in } \\
\text { use }\end{array}$ & nia \\
\hline \multicolumn{5}{|l|}{ Layout } \\
\hline 1 The bedroom is separate from other rooms & $\bullet$ & 0 & O & 0 \\
\hline 2 There is direct access to the bathroom from the bedroom & 0 & ○ & 0 & $\mathrm{O}$ \\
\hline 3 The double bedroom can accom modate twin beds & 0 & 0 & 0 & 0 \\
\hline 4 The bed in the bedroom can be accomm odated in more than one position & - & 0 & 0 & 0 \\
\hline 5 There is more than $1200 \mathrm{~mm}$ space on either side of the bed & $\odot$ & 0 & 0 & 0 \\
\hline 6 There is more than $1500 \mathrm{~mm}$ space on one side of the bed & 0 & 0 & 0 & () \\
\hline 7 There is space in the bedroom for a chair(s) & 0 & 0 & 0 & 0 \\
\hline 8 There is space in the bedroom for a bedside table either side of the bed & ○ & 0 & 0 & 0 \\
\hline 9 There is a tree-standing wardrobe or built-in wardrobe in the bedroom & - & 0 & 0 & 0 \\
\hline 10 There is space in the bedroom for a chest of dramers andior a dressing table & $\circ$ & 0 & 0 & O \\
\hline 11 There is provision for a TV in the bedroom & 0 & 0 & 0 & - \\
\hline 12 There is space in the bedroom to allowuse of a hoist & 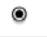 & 0 & 0 & O \\
\hline 13 There is space in the bedroom for special equipm ent, e.g. 02 cylinders & O & 0 & 0 & (c) \\
\hline 14 There is space in the bedroom for a wheelchair turning dirde more than $1500 \mathrm{~mm}$ in diameter & 0 & 0 & 0 & 0 \\
\hline 15 The distance between the opening edge of the door and any adjacent wall is more than $300 \mathrm{~mm}$ & 0 & 0 & 0 & $\circ$ \\
\hline \multicolumn{5}{|l|}{ Building Elements } \\
\hline 16 The colour of the bedroom door contrasts with the colour of the surrounding walls & $\circ$ & 0 & O & 0 \\
\hline 17 The bedroom door has a non-reflective satin or matt finish & 0 & 0 & 0 & 0 \\
\hline 18 The colour of the bedroom door handle contrasts with the colour of the bedroom door & $\circ$ & 0 & 0 & 0 \\
\hline 19 The door furniture on the bedroom door has a non-reflective finish & 0 & ○ & 0 & 0 \\
\hline 20 The bedroom door handle is easy to operate (D-shape, L-shape, lever) & - & 0 & 0 & 0 \\
\hline 21 The bedroom door opens with minimum pressure & 0 & 0 & 0 & 0 \\
\hline 22 The bedroom threshold is flush with general floor level & $\circ$ & 0 & 0 & 0 \\
\hline 23 The bedroom door has a clear opening more than $800 \mathrm{~mm}$ wide & ○ & 0 & 0 & 0 \\
\hline \multicolumn{5}{|l|}{ Environmental Design } \\
\hline 24 The bedroom has natural light & 0 & 0 & 0 & 0 \\
\hline 25 The bedroom receives sunlight in the morning or in the atternoon & 0 & $\mathrm{O}$ & 0 & $\mathrm{O}$ \\
\hline 26 The bedroom receives sunlight in the morning and afternoon & 0 & 0 & 0 & ○ \\
\hline $27 S, E, W$ facing windows are tree from obstruction to direct sunlight & 0 & 0 & 0 & ○ \\
\hline
\end{tabular}




\begin{tabular}{|c|c|c|c|c|}
\hline 28 The bedroom windom(s) has a vew of the open sky & 0 & 0 & O & 0 \\
\hline 29 The bedroom window(s) overlooks outdoor spaces where there is human activity & ○ & 0 & 0 & o \\
\hline 30 The view from the bedroom consists of near and distant features of interest & 0 & 0 & 0 & o \\
\hline 31 The view from the bedroom windowconsists of natural features & 0 & 0 & ○ & o \\
\hline 32 The view from the bedroom windowis tree from obstructions, e.g. a blank mall & 0 & 0 & 0 & 0 \\
\hline 33 The sill height is less than $600 \mathrm{~mm}$ above floor level & 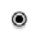 & O & O & o \\
\hline 34 The bedroom has a dayight factor more than 2 & 0 & 0 & O & ○ \\
\hline 35 The bedroom is dark at night [Glossary 4.18] & 0 & 0 & 0 & $\odot$ \\
\hline 36 There are shading devices for $S, E, W$ facing windows & 0 & 0 & 0 & 0 \\
\hline 37 The shading devices can be operated by people using the bedroom & 0 & 0 & 0 & 0 \\
\hline 38 The shading devices fully cover the bedroom window(s) & 0 & 0 & 0 & $\odot$ \\
\hline 39 The bedroom has natural ventilation & 0 & 0 & 0 & o \\
\hline 40 The bedroom window(s) has a lock & - & 0 & 0 & 0 \\
\hline $\begin{array}{l}\text { The bedroom windowcan be opened by easily operated controls fixed more than } 750 \mathrm{~mm} \text { and less than } \\
41200 \mathrm{~mm} \text { from floor level }\end{array}$ & 0 & 0 & 0 & $\odot$ \\
\hline 42 Fitted lights closest to windows can be switched on and off independently of lights furthest from windows & 0 & 0 & 0 & 0 \\
\hline 43 The artificial light is mell distributed with no areas of deep shadow & 0 & O & 0 & O \\
\hline 44 The bedroom light fittings conceal the light source & 0 & 0 & 0 & 0 \\
\hline 45 The bedroom light bulbs can be replaced trom floor level & 0 & ○ & 0 & $\odot$ \\
\hline 46 The bedroom lighting can be dimmed & 0 & O & 0 & $\odot$ \\
\hline 47 The electric light illuminanos is more than 150 lux & 0 & O & 0 & ○ \\
\hline 48 The bedroom has a radiator or under floor heating & ○ & 0 & 0 & 0 \\
\hline 49 The radiator or underfloor heating has low surface tem perature & 0 & 0 & 0 & $\odot$ \\
\hline 50 The room of radiator has an individual the mostatic te mperature control & O & 0 & 0 & $\odot$ \\
\hline 51 There are no wall-mounted electric heaters present & ○ & O & 0 & O \\
\hline 52 There are no portable electric heaters present & 0 & 0 & 0 & 0 \\
\hline 53 The bedroom background tem perature is $23 \mathrm{deg} C$ & 0 & 0 & 0 & - \\
\hline
\end{tabular}

Services and Systems

\begin{tabular}{l|llll}
\hline 54 The bedroom has an alarm call & 0 & 0 & 0 \\
\hline 55 The bedroom has a smoke detector & 0 & 0 & 0 \\
\hline 56 The bedroom has a telephone point(s) & 0 & 0 & 0 \\
\hline $57 \quad$ The bedroom tele phone point(s) is next to an electrical socket & 0 & 0 & 0 \\
\hline 58 The bedroom has a TV aerial point & 0 & 0 & 0 & 0 \\
\hline $59 \quad$ The TV aerial point is next to an electrical socket & 0 & 0 & 0 & 0 \\
\hline
\end{tabular}




\begin{tabular}{|c|c|c|c|c|}
\hline 60 The bedroom electrical sockets are more than $450 \mathrm{~mm}$ and less than $1200 \mathrm{~mm}$ from floor level & (-) & 0 & 0 & 0 \\
\hline 61 The bedroom electrical sockets can be reached without having to move bedroom turniture & 0 & 0 & 0 & 0 \\
\hline 62 The bedroom light switches are visible in the dark & O & O & O & (-) \\
\hline 63 The bedroom light switches are more than $1000 \mathrm{~mm}$ and less than $1200 \mathrm{~mm}$ from floor level & ○ & 0 & 0 & 0 \\
\hline \multicolumn{5}{|l|}{ Finishes } \\
\hline 64 The bedroom is decorated in a light colour with a $m$ att finish & 0 & 0 & 0 & 0 \\
\hline
\end{tabular}




\begin{tabular}{|c|c|c|c|c|}
\hline \multicolumn{3}{|l|}{ Bathroom } & \multicolumn{2}{|c|}{ Cupboards ” } \\
\hline No. TEEM & yes & no & $\begin{array}{l}\text { not in } \\
\text { use }\end{array}$ & n/a \\
\hline \multicolumn{5}{|l|}{ Layout } \\
\hline 1 There is a separate WC and washbasin from the main bathroom & 0 & 0 & 0 & 0 \\
\hline 2 There is a WC which can be accessed without going through a bedroom & 0 & 0 & 0 & 0 \\
\hline 3 There is space inside the bathroom for a wheelchair turning circle more than $1500 \mathrm{~mm}$ in diameter & 0 & 0 & 0 & 0 \\
\hline 4 The distance belween the opening edge of each door and any adjacent wall is more than $300 \mathrm{~mm}$ & 0 & 0 & 0 & 0 \\
\hline \multicolumn{5}{|l|}{ Building Elements } \\
\hline 5 The bathroom door colour contrasts with the surrounding wall colour & 0 & 0 & 0 & 0 \\
\hline 6 The bathroom door is has a non-reflective satin or matt finish & 0 & 0 & 0 & 0 \\
\hline 7 The bathroom door handle colour contrasts with the colour of the bathroom door & (c) & 0 & 0 & 0 \\
\hline 8 The bathroom door furniture has a non-reflective finish & 0 & 0 & 0 & 0 \\
\hline 9 The bathroom door opens outward & ( & 0 & 0 & 0 \\
\hline 10 The bathroom door has a lock which is easy to operate & 0 & 0 & 0 & 0 \\
\hline 11 The bathroom door can be unlocked from the oulside & 0 & 0 & 0 & 0 \\
\hline 12 The bathroom door handle is easy top operate (D-shape, L-shape, lever handle) & (-) & 0 & 0 & 0 \\
\hline 13 The bathroom threshold is flush & 0 & $\mathrm{O}$ & 0 & $\mathrm{O}$ \\
\hline 14 The bathroom door has a clear opening more than $800 \mathrm{~mm}$ wide & - & 0 & 0 & 0 \\
\hline \multicolumn{5}{|l|}{ Fittings - Shower } \\
\hline 15 The bathroom has a shower & 0 & 0 & 0 & 0 \\
\hline 16 The shower is localed away from the bathroom door & 0 & 0 & 0 & 0 \\
\hline 17 The shower is a walk-in shower & () & 0 & 0 & 0 \\
\hline 18 The shower is wheelchair accessible & 0 & 0 & 0 & 0 \\
\hline 19 The shower is provided with a perforated, tip-up seat with lateral protection & - & 0 & 0 & 0 \\
\hline 20 A grab rail is fitted by the shower & 0 & 0 & 0 & 0 \\
\hline 21 The shower controls are 'large cross' or 'lever handle' & 0 & 0 & 0 & 0 \\
\hline 22 The shower head can be tilted downwards & - & 0 & 0 & 0 \\
\hline 23 The shower controls are more than $750 \mathrm{~mm}$ and less than $1000 \mathrm{~mm}$ from floor level & 0 & 0 & 0 & 0 \\
\hline 24 The shower enclosure is large enough to allow a carer to be present & 0 & 0 & 0 & 0 \\
\hline 25 There is a low level shower enclosure to prevent the carer from getting wet & 0 & 0 & 0 & 0 \\
\hline 26 The shower has a safety temperature thermostat & 0 & 0 & 0 & - \\
\hline Fittings - WC & & & & \\
\hline
\end{tabular}




\begin{tabular}{l|llll}
\hline 27 The bathroom has a wC & 0 & 0 & 0 \\
\hline $28 \quad$ The toilet bowl can be reached by lateral transter from a wheelchair & 0 & 0 & 0 \\
\hline $29 \quad$ The toilet is fitted with a paddle-shaped flush & 0 & 0 & 0 & 0 \\
\hline $30 \quad$ There is provision for fitting supporting rails around the wC & 0 & 0 & 0 & 0 \\
\hline $31 \quad$ There is 600mm each side of the toilet to allow a carer to be presert & 0 & 0 & 0 & 0 \\
\hline
\end{tabular}

\begin{tabular}{|c|c|c|c|c|}
\hline \multicolumn{5}{|l|}{ Fittings - Bath } \\
\hline 32 The bathroom has a bath & 0 & ๑ & 0 & 0 \\
\hline 33 The bath is provided with a transfer seat & O & o & 0 & 0 \\
\hline 34 There is provision for a grab rall by the bath & 0 & 0 & 0 & 0 \\
\hline 35 The bath has a saiety temperature thermo stat & 0 & 0 & 0 & 0 \\
\hline
\end{tabular}

\section{Fittings - Wash Basin}

\begin{tabular}{l|llll}
\hline 36 & The bathroom has a wall mounted washbasin & 0 & 0 & 0 \\
\hline $37 \quad$ The washbasin taps are large cross' type or lever' handle & 0 & 0 & 0 \\
\hline $38 \quad$ There is provision for fixing grab rails around the mashbasin & 0 & 0 & 0 \\
\hline $39 \quad$ The washbasin has a safety tem perature them ostat & 0 & 0 & 0 \\
\hline $40 \quad$ There is more than 600mm round the sides of the washbasin to allowa carer to be present & 0 & 0 & 0 \\
\hline
\end{tabular}

Fittings - General

\begin{tabular}{l|llll}
\hline 41 The bathroom has a mirror & 0 & 0 & 0 \\
\hline 42 The mirror is suitable for people seated and standing & 0 & 0 & 0 \\
\hline 43 The bathroom has shelving for toiletries & 0 & 0 & 0 \\
\hline 44 There is a washing line in the bathroom & 0 & 0 & 0 \\
\hline
\end{tabular}

\begin{tabular}{|c|c|c|c|c|}
\hline \multicolumn{5}{|l|}{ Environmental Design } \\
\hline 45 The bathroom has natural light & $\mathrm{O}$ & ○ & 0 & O \\
\hline 46 The bathro on receives sunlight in the morning or in the atemoon & 0 & O & 0 & 0 \\
\hline 47 The bathro on reosives sunilight in the morning and in the afternoon & ० & O & O & O \\
\hline 48 The bathroon window(s) is fro sted glass & 0 & O & O & O \\
\hline 49 There are shading devices for S, E, W facing windows & 0 & 0 & 0 & $\odot$ \\
\hline 50 The shading devices can be operated by people using the bathroom & 0 & ० & 0 & 0 \\
\hline 51 The bathroom has natural ventilation & 0 & $\circ$ & O & O \\
\hline 52 The bathro on window(s) has locks & 0 & 0 & 0 & ○ \\
\hline $\begin{array}{l}53 \text { The bathroom window can be opened by easily operated controls fixed more than } 750 \mathrm{~mm} \text { and less than } \\
1200 \mathrm{~m} \text { in from floor level }\end{array}$ & 0 & 0 & 0 & $\odot$ \\
\hline 54 The artificial light is well distributed with no areas of deep shadow & 0 & O & O & O \\
\hline 55 The bathroom light fittings conceal the light sources & ○ & $\mathrm{O}$ & 0 & $\mathrm{O}$ \\
\hline
\end{tabular}




\begin{tabular}{|c|c|c|c|c|}
\hline 56 The electric light illuminanoe is more than 200 lux & 0 & 0 & O & (๑) \\
\hline 57 There is task lighting by the basin & ○ & 0 & o & o \\
\hline 58 There is task lighting over the showeribath [Glossary 4.19$]$ & ○ & 0 & 0 & 0 \\
\hline 59 The task lighting is controlled by a pull-cord which can be reached from a wheelchair & $\mathrm{O}$ & O & O & ○ \\
\hline 60 The bathroom has mechanical ventilation & 0 & 0 & 0 & 0 \\
\hline 61 The bathroom has a radiator or under floor heating & 0 & O & 0 & ○ \\
\hline 62 The racliator or underfloor heating has a low surface temperature & 0 & 0 & 0 & ○ \\
\hline 63 The room or radiator has an individual the mn ostatic te mperature control & 0 & 0 & 0 & ○ \\
\hline 64 There is a wall-m ourted electric heater & $\mathrm{O}$ & O & O & ○ \\
\hline 65 The bathroom background tem perature is $23 \mathrm{deg} \mathrm{C}$ & 0 & ० & 0 & 0 \\
\hline \multicolumn{5}{|l|}{ Services and Systems } \\
\hline 66 The bathroom has an alarm call & ○ & ○ & 0 & O \\
\hline 67 The bathroom has a shaver point & 0 & 0 & 0 & 0 \\
\hline 68 The shaver point is $m$ ore than $1000 \mathrm{~m} m$ and less than $1100 \mathrm{~m} m$ from floor level & 0 & O & O & $\odot$ \\
\hline 69 The bathroom light switches are pull--ord or are located outside the room & $\mathrm{O}$ & O & O & ○ \\
\hline
\end{tabular}

\begin{tabular}{|c|c|c|c|c|}
\hline \multicolumn{5}{|l|}{ Finishes } \\
\hline 70 The bathroom is decorated in a light colour with a matt finish & 0 & 0 & 0 & 0 \\
\hline 71 The bathroom floor is visually distinct from the bathroom fittings & 0 & 0 & 0 & 0 \\
\hline 72 The bathroom malls are visually distinct trom the bathroom floor & 0 & 0 & o & ० \\
\hline 73 The bathroom fittings are visually distinct from the bathroom walls & O & ○ & O & O \\
\hline 74 All bathroom walls are non-eflective [Glossary 6.02$]$ & ○ & 0 & 0 & 0 \\
\hline 75 The bathroom flooring is non-reflective & ○ & 0 & ० & o \\
\hline 76 The bathroom floor is properly laid and sealed & ○ & 0 & o & 0 \\
\hline 77 The bathroom flooring is non-slip & ○ & 0 & 0 & 0 \\
\hline 78 The bathroom floor $m$ aterials are easy to clean & 0 & 0 & 0 & 0 \\
\hline 79 The bathroom wall finishes are easy to clean & 0 & 0 & o & ○ \\
\hline 80 The bathroom pipe work is sealed in a duct & $\mathrm{O}$ & ○ & O & $\mathrm{O}$ \\
\hline 81 The grab rails in the bathroom are non-dinical in appearance & 0 & 0 & 0 & 0 \\
\hline
\end{tabular}




\begin{tabular}{|c|c|c|c|c|}
\hline General items & \multicolumn{4}{|c|}{ Assistive Technology } \\
\hline Ha. ITEM & yes & no & $\begin{array}{l}\text { not in } \\
\text { use }\end{array}$ & n'a \\
\hline \multicolumn{5}{|l|}{ Layout } \\
\hline 1 All rooms in the living unit except the hall are rectangular in plan [Glossary 1.05 ] & ○ & $\mathrm{O}$ & 0 & $\mathrm{O}$ \\
\hline 2 The living unit is double asped [Glossary 1.06 ] & 0 & ( & 0 & 0 \\
\hline $\begin{array}{l}\text { Neighbouring windows are more than } 22 \mathrm{~m} \text { away to m aintain privacy [ltem N/A for walk-through version of } \\
\text { EVOLVE Tool] }\end{array}$ & ○ & O & 0 & 0 \\
\hline 4 If the living unit is on the ground floor, there is an assodiated private/sem i-private extemal area (e.g. patio) & 0 & 0 & 0 & 0 \\
\hline 5 The living unit has patio doors & 0 & 0 & 0 & ○ \\
\hline 6 The living unit has space for a dining table and dining chairs & 0 & O & 0 & (- \\
\hline 7 The living unit has space for four people to sit down and have a meal at a dining table & $\mathrm{O}$ & 0 & 0 & ○ \\
\hline
\end{tabular}




\begin{tabular}{|c|c|c|c|c|}
\hline Assistive technology & \multicolumn{4}{|c|}{ Results by space » } \\
\hline Ho. ITEM & yes & no & $\begin{array}{l}\text { not in } \\
\text { use }\end{array}$ & n’a \\
\hline \multicolumn{5}{|l|}{ Layout } \\
\hline 1 The living unit has a m anual therm ostat & ○ & 0 & 0 & 0 \\
\hline 2 The living unit has a property exit sensor & 0 & O & 0 & ○ \\
\hline 3 The living unit has a temperature extreme sensor in the kitchen & ० & 0 & 0 & ○ \\
\hline 4 The living unit has a flood detector in the kitchenibathroom & 0 & 0 & 0 & - \\
\hline 5 The living unit has a carbon monoxide detector & 0 & 0 & 0 & - \\
\hline 6 The living unit has a fall detector system & 0 & 0 & 0 & 0 \\
\hline 7 The living unit has a motion sensor & 0 & 0 & 0 & ○ \\
\hline 8 The living unit has a 2-way com municator with a monitoring centre & 0 & 0 & 0 & 0 \\
\hline
\end{tabular}




\section{evolve}

Living unit: Results for individual spaces

Results for unit $x$

The Village of Humber Heights

Display chart for Entrance

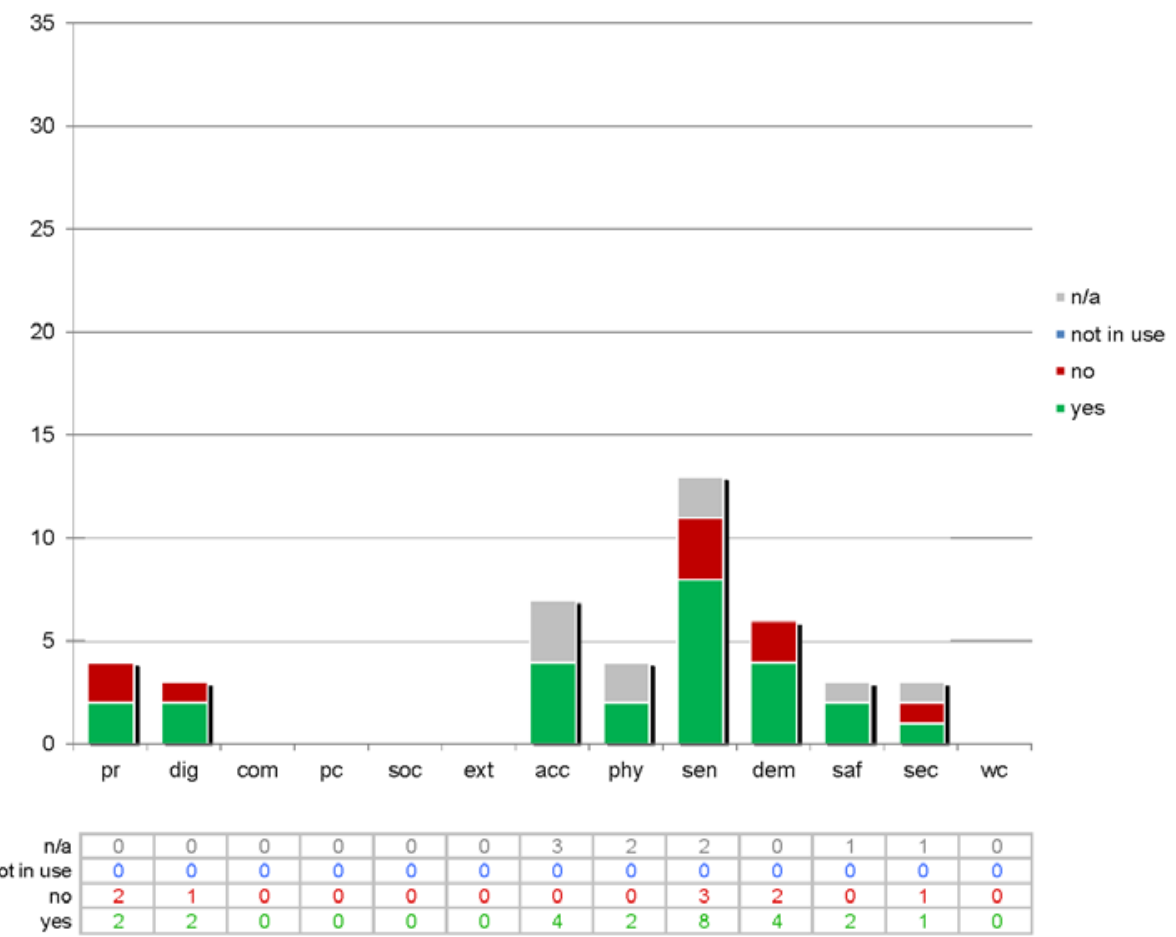




\section{evolve}

Living unit: Results for individual spaces

Results for unit $»$

The Village of Humber Heights

Display chart for Hall

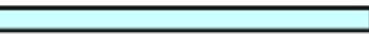

35

30

25

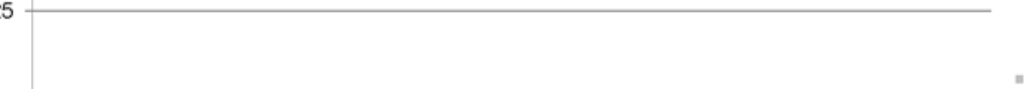

20

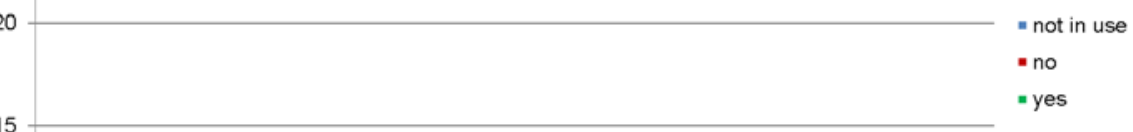

15

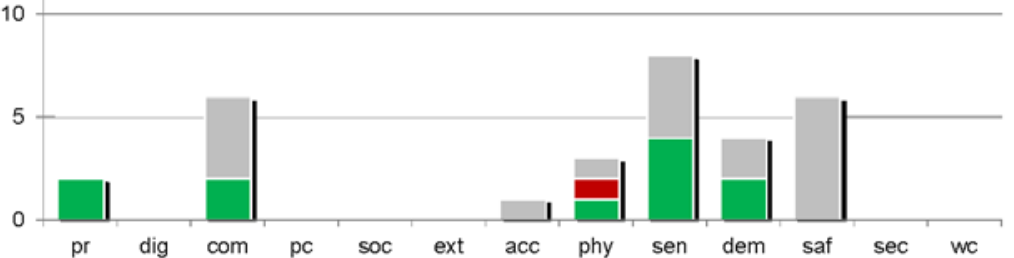

pr dig com pc soc ext acc phy sen dem saf sec wc

\begin{tabular}{|c|c|c|c|c|c|c|c|c|c|c|c|c|c|}
\hline $\mathrm{n} / \mathrm{a}$ & 0 & 0 & 4 & 0 & 0 & 0 & 1 & 1 & 4 & 2 & 6 & 0 & 0 \\
\hline not in use & 0 & 0 & 0 & 0 & 0 & 0 & 0 & 0 & 0 & 0 & 0 & 0 & 0 \\
\hline no & 0 & 0 & 0 & 0 & 0 & 0 & 0 & 1 & 0 & 0 & 0 & 0 & 0 \\
\hline yes & 2 & 0 & 2 & 0 & 0 & 0 & 0 & 1 & 4 & 2 & 0 & 0 & 0 \\
\hline
\end{tabular}


evolve

Living unit: Results for individual spaces

Results for unit

The Village of Humber Heights

Display chart for Double bedroom

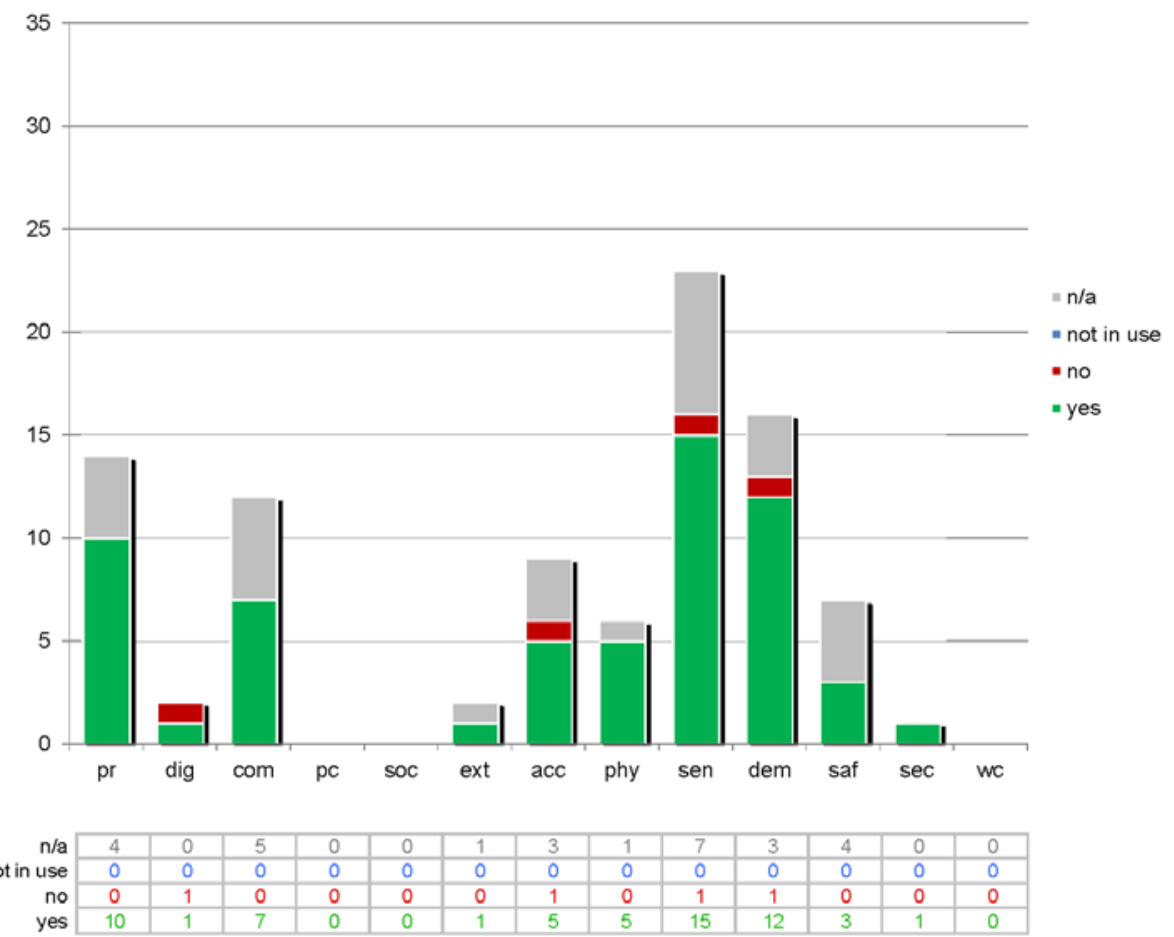


evolve

Living unit: Results for individual spaces

Results for unit »

The Village of Humber Heights

Display chart for Bathroom

35

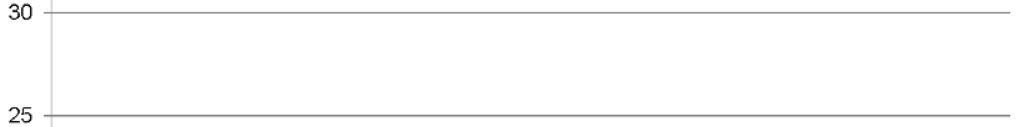
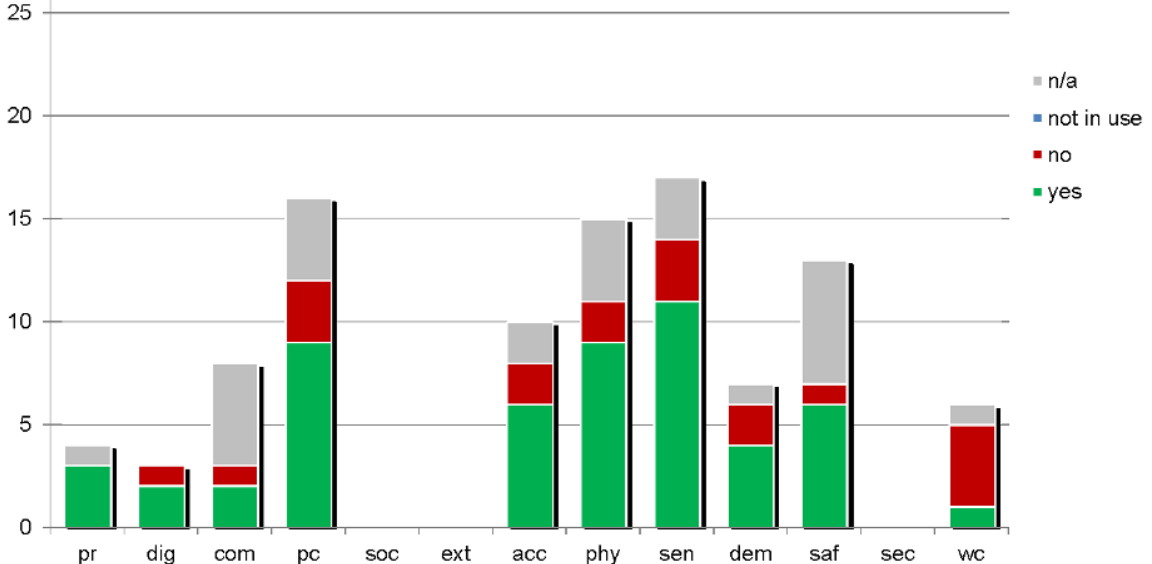

\begin{tabular}{|c|c|c|c|c|c|c|c|c|c|c|c|c|c|}
\hline $\mathrm{n} / \mathrm{a}$ & 1 & 0 & 5 & 4 & 0 & 0 & 2 & 4 & 3 & 1 & 6 & 0 & 1 \\
\hline in us & 0 & 0 & 0 & 0 & 0 & 0 & 0 & 0 & 0 & 0 & 0 & 0 & 0 \\
\hline no & 0 & 1 & 1 & 3 & 0 & 0 & 2 & 2 & 3 & 2 & 1 & 0 & 4 \\
\hline yes & 3 & 2 & 2 & 9 & 0 & 0 & 6 & 9 & 11 & 4 & 6 & 0 & 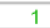 \\
\hline
\end{tabular}




\section{evolve}

Living unit: Results for individual spaces

Results for unit

The Village of Humber Heights

Display chart for General items

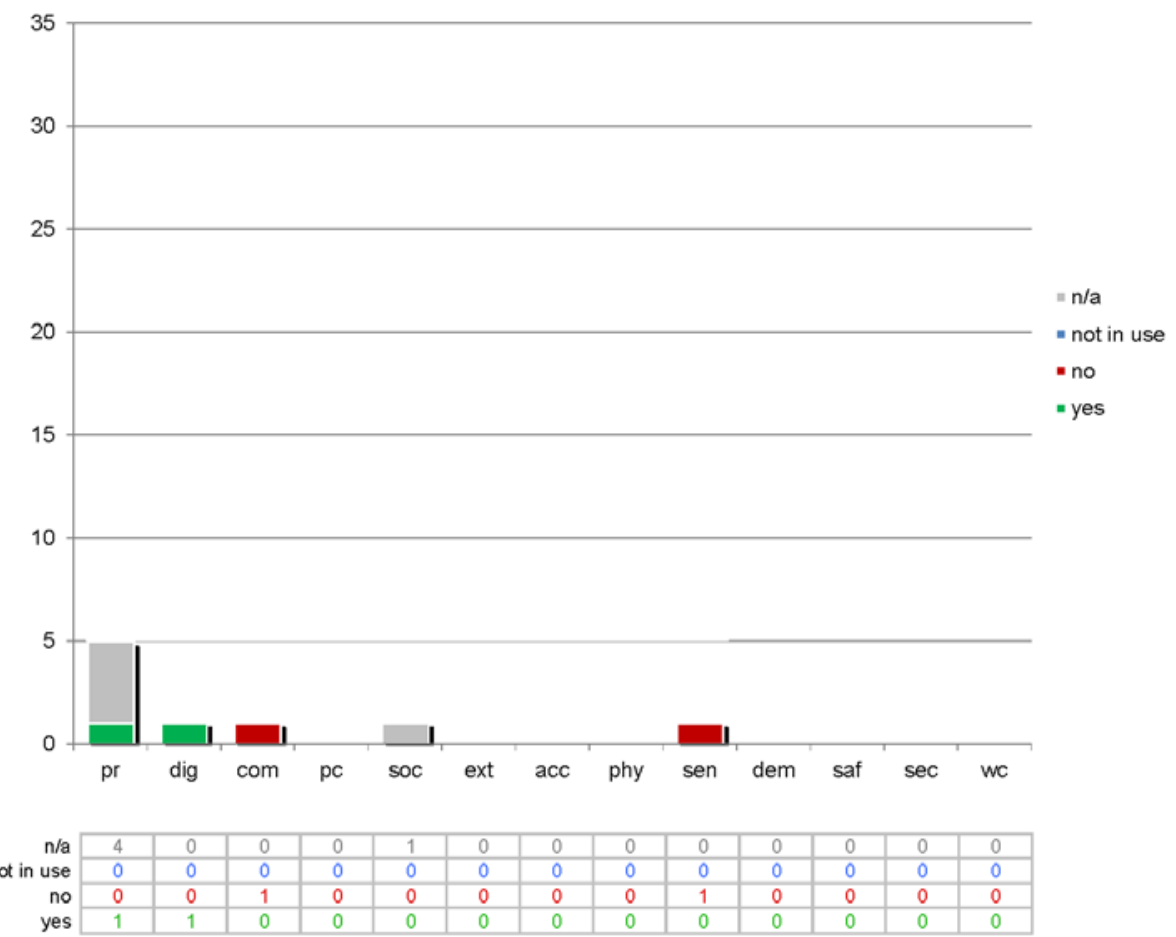


evolve

Living unit: Results for individual spaces

Results for unit »

The Village of Humber Heights

Display chart for Assistive technology

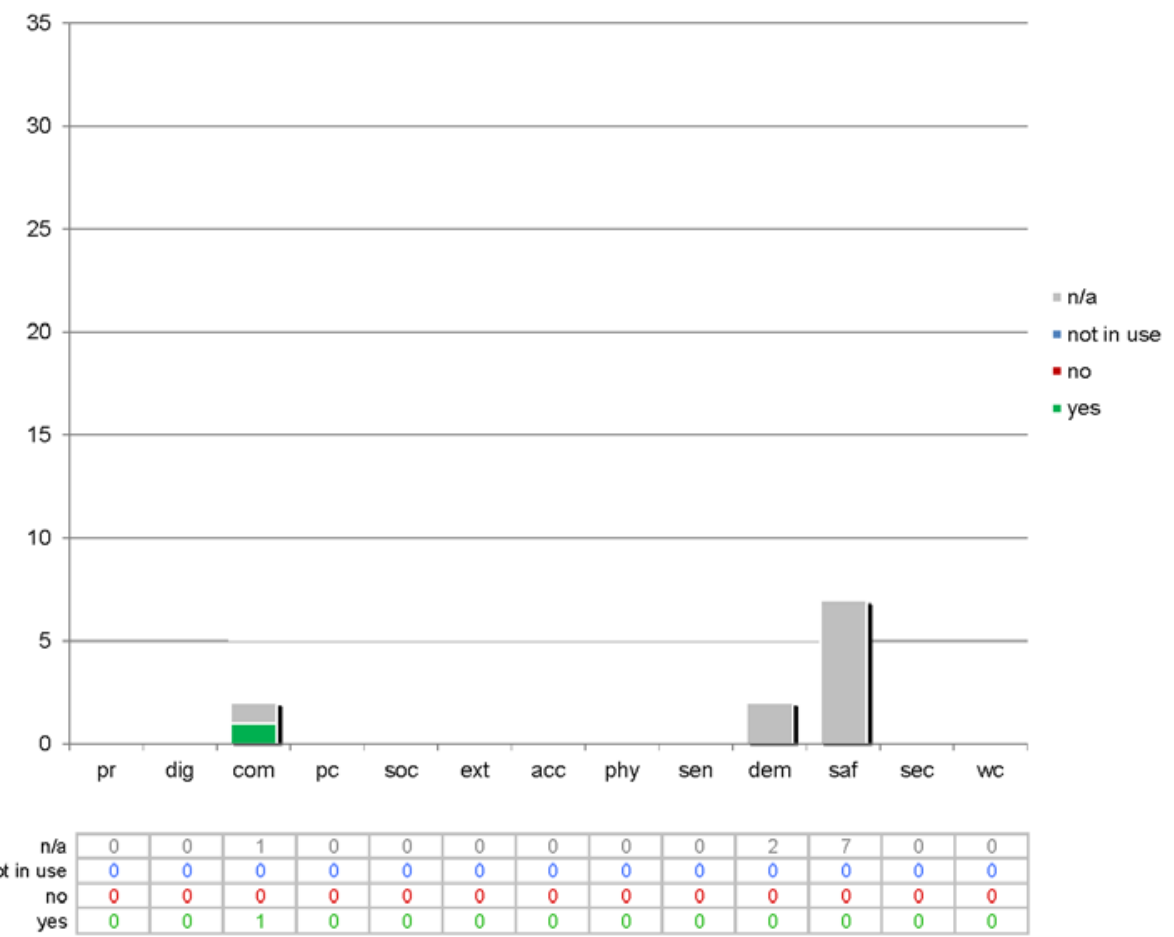




\section{evolve \\ Living unit: Results for unit}

The Village of Humber Heights

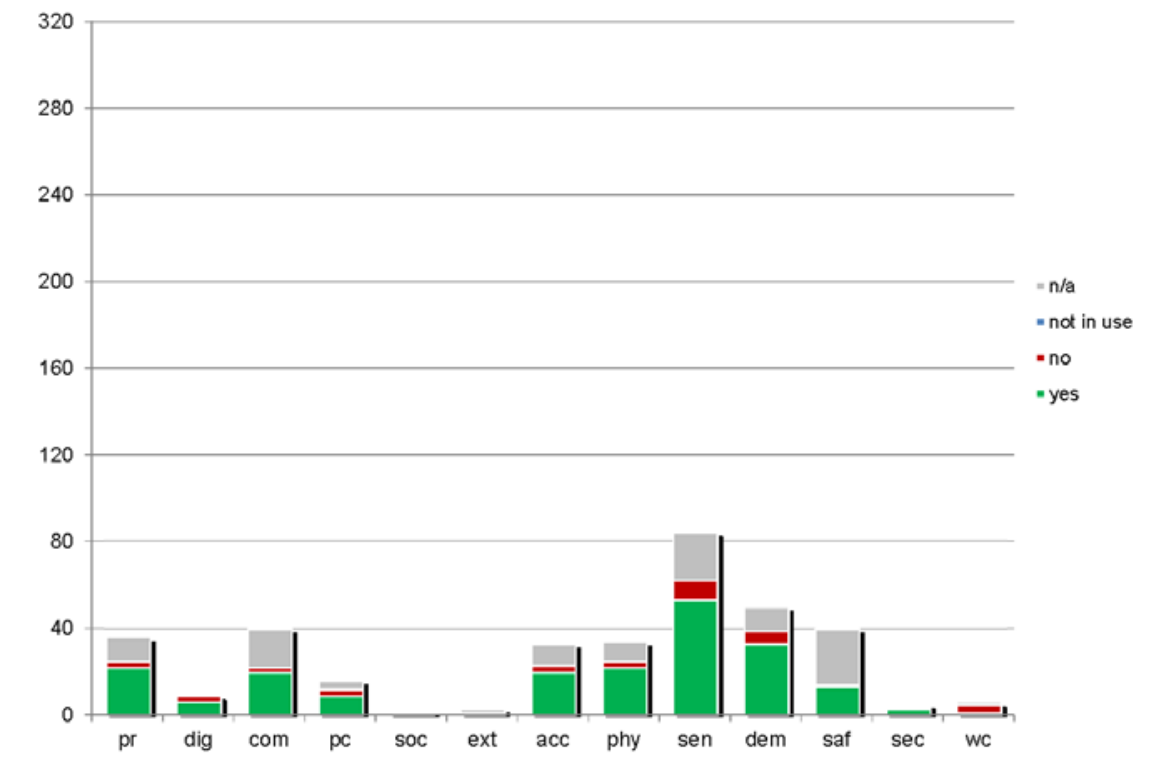

\begin{tabular}{|r|c|c|c|c|c|c|c|c|c|c|c|c|c|} 
n/a & \multicolumn{1}{|c|}{11} & 0 & 18 & 4 & 1 & 2 & 10 & 9 & 22 & 11 & 26 & 1 & 1 \\
\hline not in use & 0 & 0 & 0 & 0 & 0 & 0 & 0 & 0 & 0 & 0 & 0 & 0 & 0 \\
\hline no & 3 & 3 & 2 & 3 & 0 & 0 & 3 & 3 & 9 & 6 & 1 & 1 & 4 \\
\hline yes & 22 & 6 & 20 & 9 & 1 & 1 & 20 & 22 & 53 & 33 & 13 & 3 & 1 \\
\hline
\end{tabular}




\begin{tabular}{|c|c|c|c|c|c|c|c|c|c|c|c|c|c|c|c|c|c|c|c|c|c|c|c|c|c|c|}
\hline $\begin{array}{l}\text { Control sheet for results } \\
\text { calculations: DO NOT }\end{array}$ & domair & weigh & ting & & & & & & & & & & & domail & coun & tyes & & & & & & & & & & \\
\hline & $\mathrm{pr}$ & dig & com & $\mathrm{pc}$ & soc & ext & acc & phy & sen & dem & saf & $e c$ & & pr & dig & $\infty m$ & pc & $\mathrm{soc}$ & ext & acc & phy & sen & dem & saf & $\mathrm{sec}$ & \\
\hline Total & 39 & 10 & 47 & 16 & 2 & 3 & 34 & 40 & 88 & 52 & 44 & 8 & 6 & 22 & 6 & 20 & 9 & 1 & 1 & 20 & 22 & 53 & 33 & 13 & & 3 \\
\hline Entrance & 4 & 3 & 0 & 0 & 0 & 0 & 7 & 6 & 14 & 6 & 3 & 4 & 0 & 2 & 2 & 0 & 0 & 0 & 0 & 4 & 2 & 8 & 4 & 2 & 2 & 1 \\
\hline N/A. Alternative entrance & 0 & 0 & 0 & 0 & 0 & 0 & 0 & 0 & 0 & 0 & 0 & 0 & 0 & 0 & 0 & 0 & 0 & 0 & 0 & 0 & 0 & 0 & 0 & 0 & 0 & 0 \\
\hline Hall & 2 & 0 & 10 & 0 & 0 & 0 & 1 & 4 & 9 & 4 & 7 & 1 & 0 & 2 & 0 & 2 & 0 & 0 & 0 & 0 & 1 & 4 & 2 & 0 & 0 & 0 \\
\hline Lounge & 9 & 0 & 12 & 0 & 1 & 1 & 7 & 6 & 22 & 15 & 6 & 1 & 0 & 4 & 0 & 8 & 0 & 1 & 0 & 5 & 5 & 15 & 11 & 2 & 2 & 1 \\
\hline N/A: Kitchen & 0 & 0 & 0 & 0 & 0 & 0 & 0 & 0 & 0 & 0 & 0 & 0 & 0 & 0 & 0 & 0 & 0 & 0 & 0 & 0 & 0 & 0 & 0 & 0 & 0 & 0 \\
\hline Dcuble becroom & 15 & 2 & 12 & 0 & 0 & 2 & 9 & 6 & 23 & 16 & 7 & 1 & 0 & 10 & 1 & 7 & 0 & 0 & 1 & 5 & 5 & 15 & 12 & 3 & 3 & 1 \\
\hline N/A: Single bedroom & 0 & 0 & 0 & 0 & 0 & 0 & 0 & 0 & 0 & 0 & 0 & 0 & 0 & 0 & 0 & 0 & 0 & 0 & 0 & 0 & 0 & 0 & 0 & 0 & 0 & 0 \\
\hline Bathroom & 4 & 4 & 10 & 16 & 0 & 0 & 10 & 18 & 19 & 9 & 14 & 1 & 6 & 3 & 2 & 2 & 9 & 0 & 0 & 6 & 9 & 11 & 4 & 6 & 6 & 0 \\
\hline N/A: Cupboards & 0 & 0 & 0 & 0 & 0 & 0 & 0 & 0 & 0 & 0 & 0 & 0 & 0 & 0 & 0 & 0 & 0 & 0 & 0 & 0 & 0 & 0 & 0 & 0 & 0 & 0 \\
\hline General items & 5 & 1 & 1 & 0 & 1 & 0 & 0 & 0 & 1 & 0 & 0 & 0 & 0 & 1 & 1 & 0 & 0 & 0 & 0 & 0 & 0 & 0 & 0 & 0 & 0 & 0 \\
\hline Assistive technology & 0 & 0 & 2 & 0 & 0 & 0 & 0 & 0 & 0 & 2 & 7 & 0 & 0 & 0 & 0 & 1 & 0 & 0 & 0 & 0 & 0 & 0 & 0 & 0 & 0 & 0 \\
\hline
\end{tabular}


WC pr dig com pc soc ext acc phy sen dem saf sec wc

pr dig com pc soc ext acc phy sen dem saf sec wc pr dig

\begin{tabular}{cccccccccccccccccccccccccccccc}
1 & 3 & 3 & 2 & 3 & 0 & 0 & 3 & 3 & 9 & 6 & 1 & 1 & 4 & 0 & 0 & 0 & 0 & 0 & 0 & 0 & 0 & 0 & 0 & 0 & 0 & 0 & 11 & 0 \\
\hline 0 & 2 & 1 & 0 & 0 & 0 & 0 & 0 & 0 & 3 & 2 & 0 & 1 & 0 & 0 & 0 & 0 & 0 & 0 & 0 & 0 & 0 & 0 & 0 & 0 & 0 & 0 & 0 & 0
\end{tabular}

$\begin{array}{llllllllllllllllllllllllllllllllllll}0 & 0 & 0 & 0 & 0 & 0 & 0 & 0 & 0 & 0 & 0 & 0 & 0 & 0 & 0 & 0 & 0 & 0 & 0 & 0 & 0 & 0 & 0 & 0 & 0 & 0 & 0 & 0 & 0\end{array}$

$\begin{array}{lllllllllllllllllllllllllllllllllll}0 & 0 & 0 & 0 & 0 & 0 & 0 & 0 & 1 & 0 & 0 & 0 & 0 & 0 & 0 & 0 & 0 & 0 & 0 & 0 & 0 & 0 & 0 & 0 & 0 & 0 & 0 & 0 & 0\end{array}$

$\begin{array}{lllllllllllllllllllllllllllllllllll}0 & 1 & 0 & 0 & 0 & 0 & 0 & 0 & 0 & 1 & 1 & 0 & 0 & 0 & 0 & 0 & 0 & 0 & 0 & 0 & 0 & 0 & 0 & 0 & 0 & 0 & 0 & 2 & 0\end{array}$

$\begin{array}{llllllllllllllllllllllllllllllllllllll}0 & 0 & 0 & 0 & 0 & 0 & 0 & 0 & 0 & 0 & 0 & 0 & 0 & 0 & 0 & 0 & 0 & 0 & 0 & 0 & 0 & 0 & 0 & 0 & 0 & 0 & 0 & 0 & 0\end{array}$

$\begin{array}{llllllllllllllllllllllllllllllllllll}0 & 0 & 1 & 0 & 0 & 0 & 0 & 1 & 0 & 1 & 1 & 0 & 0 & 0 & 0 & 0 & 0 & 0 & 0 & 0 & 0 & 0 & 0 & 0 & 0 & 0 & 0 & 4 & 0\end{array}$

$\begin{array}{lllllllllllllllllllllllllllllllllll}0 & 0 & 0 & 0 & 0 & 0 & 0 & 0 & 0 & 0 & 0 & 0 & 0 & 0 & 0 & 0 & 0 & 0 & 0 & 0 & 0 & 0 & 0 & 0 & 0 & 0 & 0 & 0 & 0\end{array}$

$\begin{array}{lllllllllllllllllllllllllllllllllll}1 & 0 & 1 & 1 & 3 & 0 & 0 & 2 & 2 & 3 & 2 & 1 & 0 & 4 & 0 & 0 & 0 & 0 & 0 & 0 & 0 & 0 & 0 & 0 & 0 & 0 & 0 & 1 & 0\end{array}$

$\begin{array}{lllllllllllllllllllllllllllllllllll}0 & 0 & 0 & 0 & 0 & 0 & 0 & 0 & 0 & 0 & 0 & 0 & 0 & 0 & 0 & 0 & 0 & 0 & 0 & 0 & 0 & 0 & 0 & 0 & 0 & 0 & 0 & 0 & 0\end{array}$

$\begin{array}{lllllllllllllllllllllllllllllllllllll}0 & 0 & 0 & 1 & 0 & 0 & 0 & 0 & 0 & 1 & 0 & 0 & 0 & 0 & 0 & 0 & 0 & 0 & 0 & 0 & 0 & 0 & 0 & 0 & 0 & 0 & 0 & 4 & 0\end{array}$

$\begin{array}{llllllllllllllllllllllllllllllllllll}0 & 0 & 0 & 0 & 0 & 0 & 0 & 0 & 0 & 0 & 0 & 0 & 0 & 0 & 0 & 0 & 0 & 0 & 0 & 0 & 0 & 0 & 0 & 0 & 0 & 0 & 0 & 0 & 0\end{array}$ 
tn $/ a$

com pc soc ext acc phy sen dem saf sec wc

\begin{tabular}{rrrrrrrrrrr}
18 & 4 & 1 & 2 & 10 & 9 & 22 & 11 & 26 & 1 & 1 \\
\hline 0 & 0 & 0 & 0 & 3 & 2 & 2 & 0 & 1 & 1 & 0
\end{tabular}

$\begin{array}{lllllllllll}0 & 0 & 0 & 0 & 0 & 0 & 0 & 0 & 0 & 0 & 0\end{array}$

$\begin{array}{lllllllllll}4 & 0 & 0 & 0 & 1 & 1 & 4 & 2 & 6 & 0 & 0\end{array}$

$\begin{array}{lllllllllll}3 & 0 & 0 & 1 & 1 & 1 & 6 & 3 & 2 & 0 & 0\end{array}$

$\begin{array}{lllllllllll}0 & 0 & 0 & 0 & 0 & 0 & 0 & 0 & 0 & 0 & 0\end{array}$

$\begin{array}{lllllllllll}5 & 0 & 0 & 1 & 3 & 1 & 7 & 3 & 4 & 0 & 0\end{array}$

$\begin{array}{lllllllllll}0 & 0 & 0 & 0 & 0 & 0 & 0 & 0 & 0 & 0 & 0\end{array}$

$\begin{array}{lllllllllll}5 & 4 & 0 & 0 & 2 & 4 & 3 & 1 & 6 & 0 & 1\end{array}$

$\begin{array}{lllllllllll}0 & 0 & 0 & 0 & 0 & 0 & 0 & 0 & 0 & 0 & 0\end{array}$

$\begin{array}{lllllllllll}0 & 0 & 1 & 0 & 0 & 0 & 0 & 0 & 0 & 0 & 0\end{array}$

$\begin{array}{llllllllll}0 & 0 & 0 & 0 & 0 & 0 & 2 & 7 & 0 & 0\end{array}$ 


\begin{tabular}{|c|c|c|c|c|c|}
\hline & \multicolumn{3}{|l|}{ Communal Facilities: Generic } & \multicolumn{2}{|c|}{ Main Lounge } \\
\hline \multicolumn{2}{|c|}{ Na. ITEM } & yes & no & $\begin{array}{l}\text { not in } \\
\text { use }\end{array}$ & n'a \\
\hline \multicolumn{6}{|c|}{ B uilding Elements } \\
\hline 1 & The colour of doors contrasts with the colour of the surrounding walls & - & 0 & 0 & 0 \\
\hline 2 & Doors have a non-eflective satin or matt finish & 0 & 0 & 0 & 0 \\
\hline 3 & The colour of door handles contrasts with the colour of doors & $\circ$ & 0 & 0 & 0 \\
\hline 4 & Door furniture has a non-reflective finish & $\circ$ & 0 & 0 & 0 \\
\hline 5 & Door handles are easy to operate (D-shape, L-shape, lever handle) & 0 & 0 & 0 & 0 \\
\hline 6 & Doors open with minimum pressure & $\circ$ & 0 & 0 & 0 \\
\hline 7 & Thresholds are flush with general floor level & $\circ$ & $\mathrm{O}$ & 0 & 0 \\
\hline 8 & Doors have a clear opening more than $800 \mathrm{~mm}$ wide & - & 0 & 0 & 0 \\
\hline \multicolumn{6}{|c|}{ Emironmental Design } \\
\hline 9 & Windows have locks & - & 0 & 0 & 0 \\
\hline 10 & $\begin{array}{l}\text { Windows can be opened by easily operated controls fixed } \mathrm{m} \text { ore than } 750 \mathrm{~mm} \text { and less than } 1200 \mathrm{~m} \mathrm{~m} \text { from } \\
\text { floor level }\end{array}$ & 0 & 0 & 0 & 0 \\
\hline 11 & Fitted lights dosest to the windo ws can be switched on and off independently of lights furthest from windo ws & 0 & $\mathrm{O}$ & O & $\circ$ \\
\hline 12 & Living units have a radiator or under floor heating & - & 0 & 0 & 0 \\
\hline 13 & The radiator or underfloor heating has a low surface tem perature & - & 0 & 0 & 0 \\
\hline 14 & Rooms or radiators have an individual thermos tatic tem perature control & ○ & 0 & 0 & 0 \\
\hline \multicolumn{6}{|c|}{ Sevices and Systems } \\
\hline 15 & Rooms have an alarm system & ○ & 0 & 0 & 0 \\
\hline 16 & Rooms have smoke detectors & ○ & 0 & 0 & 0 \\
\hline 17 & Electrical sockets are more than $450 \mathrm{~mm}$ and less than $1200 \mathrm{~mm}$ from floor level & 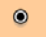 & 0 & 0 & 0 \\
\hline 18 & Light switches are more than $1000 \mathrm{~mm}$ and less than $1200 \mathrm{~mm}$ from floor level & $\circ$ & $\mathrm{O}$ & 0 & 0 \\
\hline
\end{tabular}




\begin{tabular}{|c|c|c|c|c|}
\hline Main tounge & & & Dining $R$ & Room $*$ \\
\hline Ho. ITEM & yes & no & $\begin{array}{l}\text { not in } \\
\text { use }\end{array}$ & n'a \\
\hline \multicolumn{5}{|l|}{ Layout } \\
\hline 1 The lounge and dining area occupy distinctly separate spaces & $\bullet$ & 0 & 0 & 0 \\
\hline 2 The lounge is located near to the main entrance & - & 0 & 0 & 0 \\
\hline 3 The lounge is visible from the $m$ ain entrance & 0 & 0 & o & 0 \\
\hline 4 There is a small tea kitchen adjacent to the lounge & $\circ$ & o & o & 0 \\
\hline $5 \mathrm{There}$ is a WC close to the $m$ ain lounge & 0 & 0 & 0 & 0 \\
\hline 6 The lounge has direct access to gardenigarden terrace & 0 & 0 & 0 & 0 \\
\hline 7 The main lounge has storage space for CDs $10 \mathrm{VDS}$ & $\circ$ & o & 0 & $\mathrm{O}$ \\
\hline 8 The $m$ ain lounge has storage space for musical instruments & - & 0 & 0 & 0 \\
\hline 9 Wheelchairs can be integrated into the lounge's seating arangem ents & 0 & 0 & 0 & 0 \\
\hline 10 There is space inside the lounge entrance for a wheelchair turning circle more than $1500 \mathrm{~mm}$ diam eter & - & o & $\mathrm{O}$ & $\mathrm{O}$ \\
\hline 11 The distance between the opening edge of the door and any adjacent wall is more than $300 \mathrm{~mm}$ & 0 & 0 & 0 & ○ \\
\hline \multicolumn{5}{|l|}{ Building Elements } \\
\hline 12 The colour of the lounge door contrasts with the colour of the surrounding walls & 0 & 0 & 0 & 0 \\
\hline 13 The lounge door has a non reflective satin or matt finish & 0 & 0 & 0 & () \\
\hline 14 The colour of the lounge door furniture contrasts with the colour of the lounge door & 0 & 0 & 0 & 0 \\
\hline 15 The lounge door furniture has a non-reflective finish & 0 & 0 & 0 & ○ \\
\hline 16 The lounge door handle is easy to operate (D-shape, L-shape, lever handle) & 0 & 0 & 0 & ○ \\
\hline 17 The lounge door opens with minim um pressure or is pomer-assisted & 0 & 0 & 0 & - \\
\hline 18 The lounge thre shold is flush with general floor level & 0 & 0 & 0 & ○ \\
\hline 19 The lounge door has a clear opening more than $800 \mathrm{~mm}$ & 0 & 0 & 0 & 0 \\
\hline 20 The lounge thre shold with the garden is flush & 0 & o & 0 & ○ \\
\hline 21 The lounge door to the garden has a clear opening more than $800 \mathrm{~mm}$ wide & 0 & 0 & 0 & ○ \\
\hline \multicolumn{5}{|l|}{ Emironmental Design } \\
\hline 22 The lounge has natural light & 0 & 0 & o & o \\
\hline 23 The lounge receives sunlight in the morning or atternoon & ○ & 0 & 0 & 0 \\
\hline 24 The lounge receives sunlight in the morning and aftemoon & - & 0 & 0 & 0 \\
\hline $25 S, E, W$ tacing windows are tree from obstruction to direct sunlight & 0 & 0 & 0 & 0 \\
\hline
\end{tabular}




\begin{tabular}{|c|c|c|c|c|}
\hline Activity room & & & & Suite \$ \\
\hline Ho. ITEM & yes & no & $\begin{array}{l}\text { not in } \\
\text { use }\end{array}$ & náa \\
\hline \multicolumn{5}{|l|}{ Layout } \\
\hline 1 The activity room is on the $m$ ain circulation route & $\odot$ & 0 & 0 & 0 \\
\hline 2 There is space inside the activity room entrance for a wheelchair turning dirde more than $1500 \mathrm{~mm}$ diameter & ○ & 0 & 0 & 0 \\
\hline 3 The distance between the opening edge of the door and any adjacent wall is more than $300 \mathrm{~mm}$ & ○ & 0 & 0 & 0 \\
\hline \multicolumn{5}{|l|}{ Building Elements } \\
\hline 4 The colour of the activity room door contrasts with the colour of the surrounding walls & $\odot$ & 0 & 0 & 0 \\
\hline 5 The activity room door has a non-reflective satin or matt finish & ○ & 0 & 0 & 0 \\
\hline 6 The colour of the activity room door handle contrasts with the colour of the activity room door & ○ & 0 & 0 & 0 \\
\hline 7 The activity room door furniture has a non-refledive firish & $\odot$ & 0 & 0 & 0 \\
\hline 8 The activity room door handle is easy to operate (D-shape, L-shape, lever handle) & ○ & 0 & 0 & 0 \\
\hline 9 The activity room door opens with minimum pressure & ○ & 0 & 0 & 0 \\
\hline 10 The activity room threshold is flush with general floor level & $\odot$ & 0 & 0 & 0 \\
\hline 11 The activity room door has a clear opening more than $800 \mathrm{~mm}$ wide & ○ & 0 & 0 & 0 \\
\hline \multicolumn{5}{|l|}{ Fittings - Sink } \\
\hline 12 The activity room has a sink for mixingicleaning paints etc. & 0 & 0 & 0 & 0 \\
\hline 13 The activity room sink can be used for hand washing & 0 & 0 & 0 & O \\
\hline 14 The sink taps are 'cossed type' or lever & 0 & 0 & 0 & 0 \\
\hline 15 The activity room has table/oounter space near the sink & ○ & 0 & O & O \\
\hline \multicolumn{5}{|l|}{ Fittings - Tables } \\
\hline 16 The activity room has an easel(s)t table for painting on & (-) & 0 & 0 & O \\
\hline 17 The activity room has a table for writingidrawing on & ○ & 0 & 0 & 0 \\
\hline 18 There is space for two people to sit com tortably at the table & ○ & ० & 0 & O \\
\hline 19 There is space for four people to sit com fortably at the table & - & 0 & 0 & 0 \\
\hline 20 Wheelchairs can be accomm odated at the activity room tables & ○ & ० & 0 & ० \\
\hline 21 The seats in the adtivity room are the correct height for the table & ○ & $\mathrm{O}$ & $\mathrm{O}$ & O \\
\hline 22 Wheelchairs can be integrated into the activity room seating arrangem ents & ○ & 0 & 0 & 0 \\
\hline \multicolumn{5}{|l|}{ Fittings - Workbenches } \\
\hline 23 The activity room has a workbench at which people can stand & 0 & 0 & 0 & 0 \\
\hline 24 The activity room has a workbench at which people can sit & ○ & 0 & 0 & 0 \\
\hline 25 Wheelchair users can access the workbench & - & 0 & 0 & 0 \\
\hline
\end{tabular}




\begin{tabular}{|c|c|c|c|c|}
\hline Assisted bathroom & & & & WC \\
\hline Ha. ITEM & yes & no & $\begin{array}{l}\text { not in } \\
\text { use }\end{array}$ & n'a \\
\hline \multicolumn{5}{|l|}{ Layout } \\
\hline 1 There is an assisted bathroom on every floor & ○ & 0 & 0 & 0 \\
\hline 2 The assisted bathroom contains a changing facility, i.e. a cubide & ○ & $\odot$ & O & O \\
\hline 3 There is space inside the assisted bathroom for a wheelchair turning circle more than $1500 \mathrm{~mm}$ in diam eter & ○ & 0 & 0 & 0 \\
\hline 4 The distance between the opening edge of the door and any adjacent wall is more than $300 \mathrm{~mm}$ & 0 & 0 & 0 & ○ \\
\hline \multicolumn{5}{|l|}{ Building Elements } \\
\hline 5 The colour of the assisted bathroom door contrasts with the colour of the surrounding walls & ○ & 0 & 0 & 0 \\
\hline 6 The assisted bathroom door has a non reflective satin or matt finish & ○ & 0 & 0 & 0 \\
\hline 7 The assisted bathroom door handle colour contrasts with the colour of the assisted bathroom door & $\odot$ & 0 & 0 & O \\
\hline 8 The assisted bathroom door furniture has a non-reflective finish & ○ & 0 & O & 0 \\
\hline 9 The assisted bathroom door handle is easy to operates (D-shape, L-shape, lever handle) & - & 0 & 0 & 0 \\
\hline 10 The assisted bathroom door opens with minim um pressure & ○ & o & 0 & 0 \\
\hline 11 The assisted bathroom door has a lock which is easy to operate & O & O & O & $\odot$ \\
\hline 12 The assisted bathroom door can be unlocked from the outside in em ergendes & 0 & 0 & 0 & ○ \\
\hline 13 The assisted bathroom threshold is flush with general floor level & ○ & 0 & 0 & 0 \\
\hline 14 When the assisted bathroom door is open privacy screens prevent viems into the room & O & O & O & ○ \\
\hline 15 The assisted bathroom door opening is more than $800 \mathrm{~mm}$ wide & ○ & 0 & 0 & 0 \\
\hline \multicolumn{5}{|l|}{ Fittings - Bath } \\
\hline 16 There is more than $700 \mathrm{~mm}$ clear space either side of the bath for carers & ○ & 0 & 0 & 0 \\
\hline 17 There is a shower fitting fixed to the bath & ○ & 0 & 0 & 0 \\
\hline 18 The assisted bathroom cont ains a seat & ○ & 0 & 0 & 0 \\
\hline 19 The bath can accomm odate a hoist & ○ & $\mathrm{O}$ & $\mathrm{O}$ & $\mathrm{O}$ \\
\hline 20 The bath has a safety tem perature them ostat & O & O & O & ○ \\
\hline \multicolumn{5}{|l|}{ Fittings - Washbasin } \\
\hline 21 The assisted bathroom contains a washbasin & ○ & 0 & 0 & 0 \\
\hline 22 The assisted bathroom contains a wall mounted washbasin & ○ & 0 & 0 & 0 \\
\hline 23 The mashbasin taps are 'large cross' type or 'lever' handle & ○ & 0 & 0 & 0 \\
\hline 24 Grab rails are fixed around the washbasin & 0 & ( ) & 0 & 0 \\
\hline
\end{tabular}




\section{evolve}

The Village of Humber Heights

Display chart for Main lounge

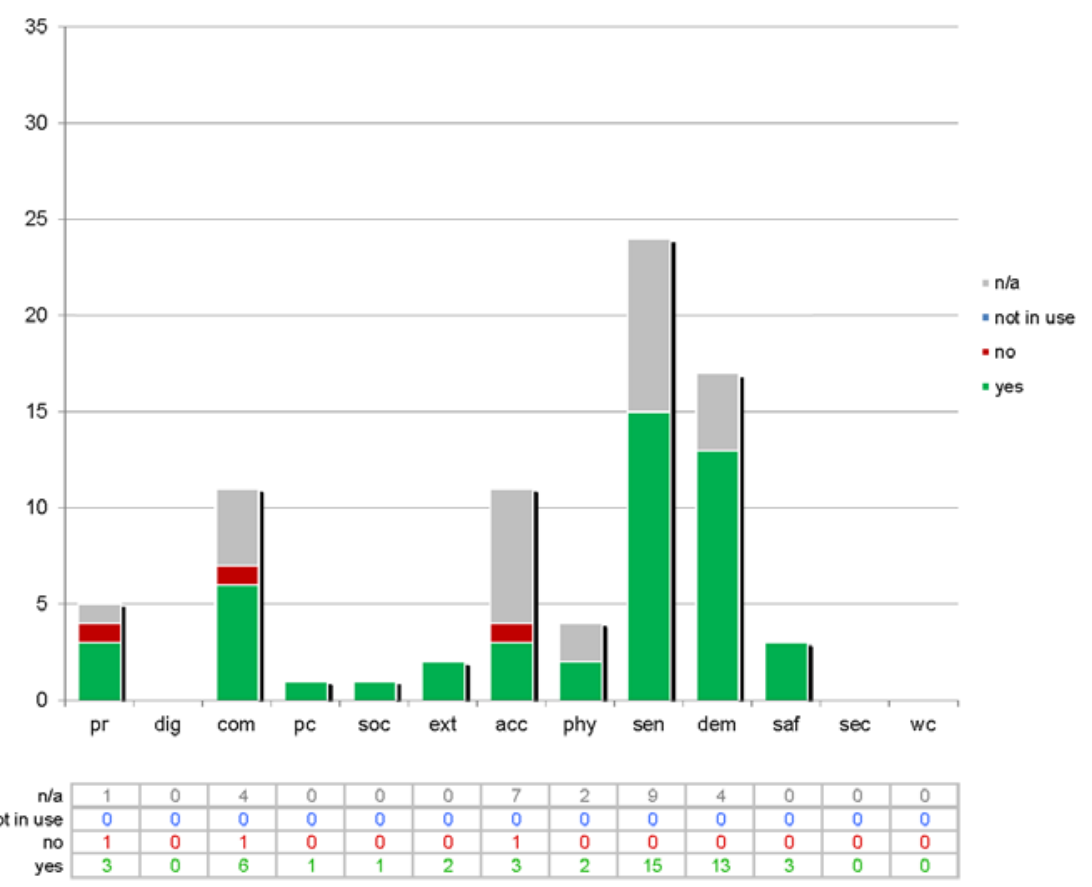


evolve

Communal Facilities: Results for individual spaces

Results for unit »

The Village of Humber Heights

Display chart for Activity room

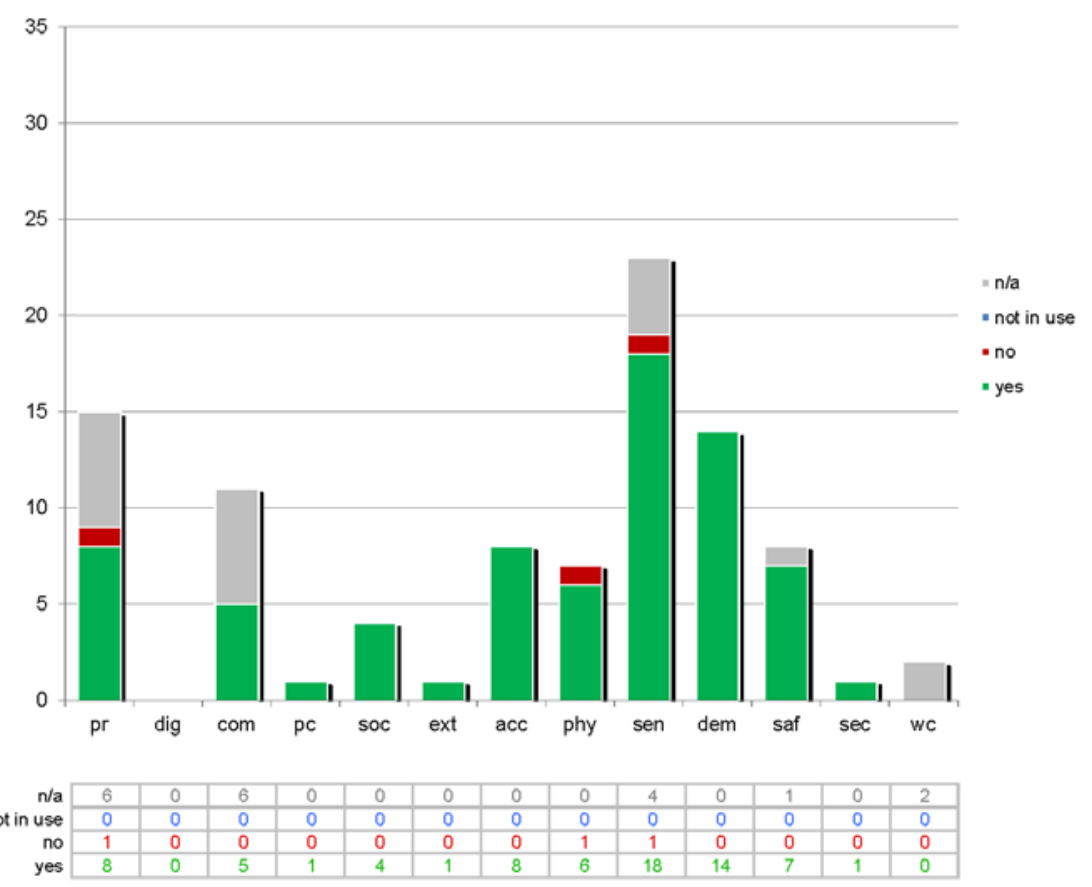


evolve

Communal Facilities: Results for individual spaces

Results for unit »

The Village of Humber Heights

Display chart for Assisted bathroom

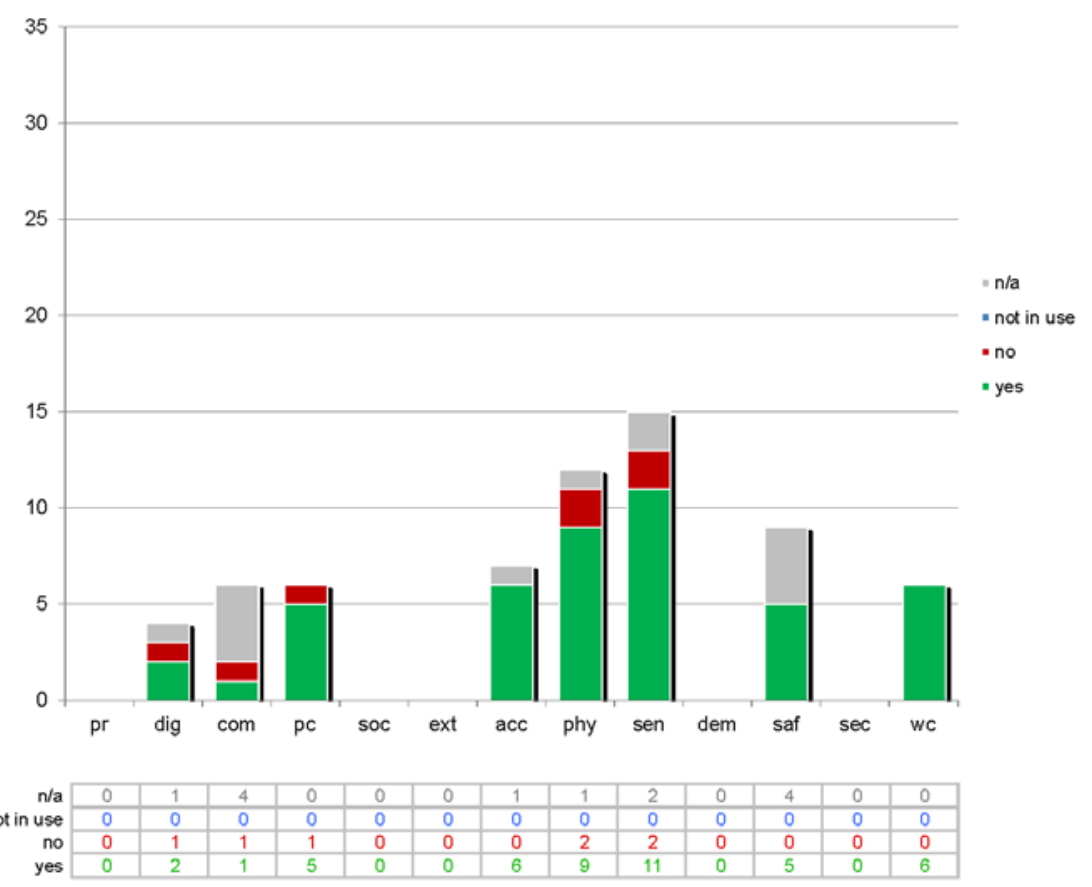




\section{evolve}

\section{Communal Facilities: Results for unit}

The Village of Humber Heights

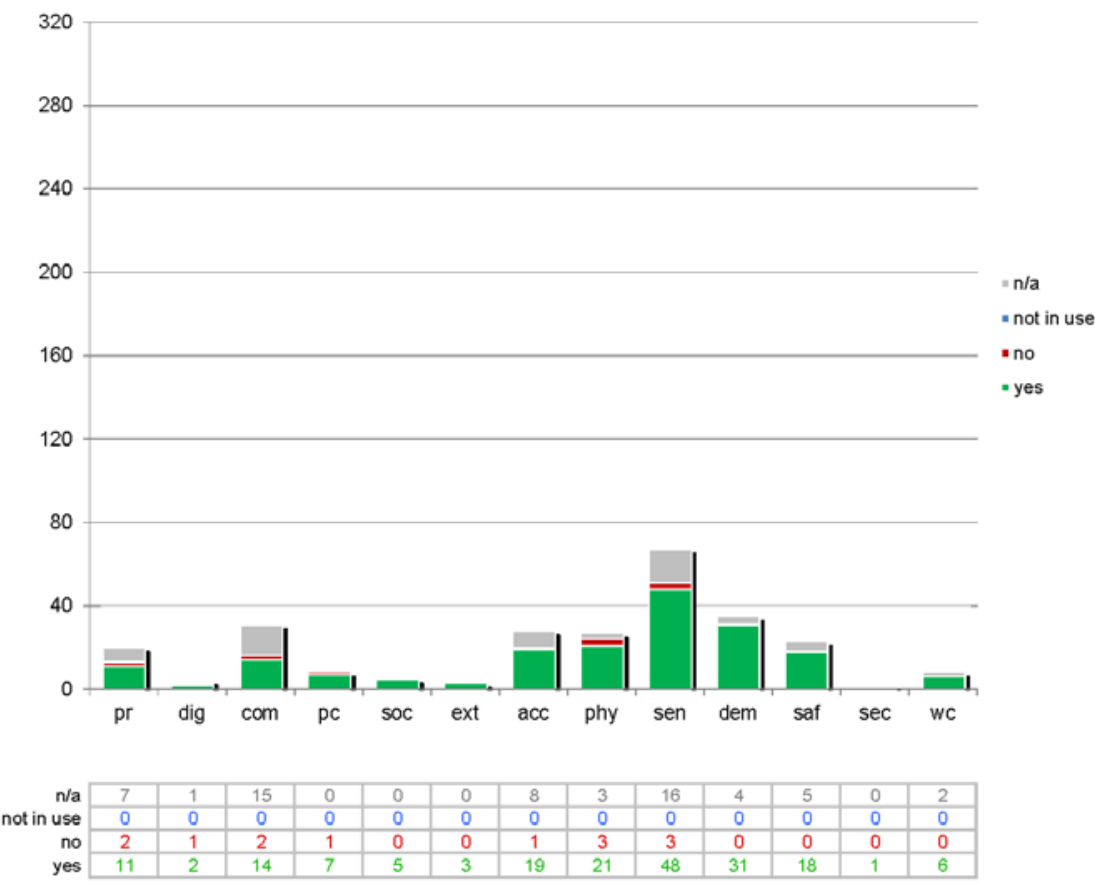




\begin{tabular}{|c|c|c|c|c|c|c|c|c|c|c|c|c|c|c|c|c|c|c|c|c|c|c|c|c|c|c|c|c|}
\hline \multirow{3}{*}{$\begin{array}{l}\text { Control shect for results } \\
\text { calculations: DO NOT } \\
\text { AMEND } \\
\text { Total }\end{array}$} & \multicolumn{14}{|c|}{ domain weighting } & \multicolumn{14}{|c|}{ domain count yes } \\
\hline & $p$ & & fig & $\infty \mathrm{m}$ & $p c$ & & ent & $s c 0$ & phy & $\operatorname{sen}$ & dem & saf & & & & dig & $\mathrm{com}$ & pe & & & ext & $a c c$ & phy & sen & dem & saf & & \\
\hline & & 21 & 5 & 50 & 9 & 6 & 4 & 34 & 32 & 93 & 48 & 26 & 5 & 9 & 11 & 2 & 14 & & 7 & 5 & 3 & 19 & 21 & 48 & 31 & 18 & 8 & 1 \\
\hline Main lounge & 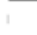 & 5 & 0 & 13 & 1 & 1 & 2 & 11 & 5 & 28 & 17 & 3 & 1 & 0 & 3 & 0 & 6 & 6 & 1 & 1 & 2 & 3 & 2 & 15 & 13 & & 3 & 0 \\
\hline N/A: Dining room & & 0 & 0 & 0 & 0 & 0 & 0 & 0 & 0 & 0 & 0 & 0 & 0 & 0 & 0 & 0 & 0 & 0 & 0 & 0 & 0 & 0 & 0 & 0 & 0 & & 0 & 0 \\
\hline Small lounge & & 1 & 0 & 13 & 1 & 1 & 1 & 7 & 5 & 24 & 15 & 3 & 1 & 0 & 0 & 0 & 2 & 2 & 0 & 0 & 0 & 2 & 4 & 4 & 4 & & 3 & 0 \\
\hline NA: Bar & & 0 & 0 & 0 & 0 & 0 & 0 & 0 & 0 & 0 & 0 & 0 & 0 & 0 & 0 & 0 & 0 & 0 & 0 & 0 & 0 & 0 & 0 & 0 & 0 & & 0 & 0 \\
\hline Activity room & 1 & 15 & 0 & 14 & 1 & 4 & 1 & 8 & 9 & 27 & 16 & 9 & 2 & 2 & 8 & 0 & 5 & 5 & 1 & 4 & 1 & 8 & 6 & 18 & 14 & & 7 & 1 \\
\hline N/A: IT suite & & 0 & 0 & 0 & 0 & 0 & 0 & 0 & 0 & 0 & 0 & 0 & 0 & 0 & 0 & 0 & & 0 & 0 & 0 & 0 & 0 & 0 & 0 & 0 & & 0 & 0 \\
\hline N/A: Ubrary & & 0 & 0 & 0 & 0 & 0 & 0 & 0 & 0 & 0 & 0 & 0 & 0 & 0 & 0 & 0 & & 0 & 0 & 0 & 0 & 0 & 0 & 0 & 0 & & 0 & 0 \\
\hline N/A: Conservatory & & 0 & 0 & 0 & 0 & 0 & 0 & 0 & 0 & 0 & 0 & 0 & 0 & 0 & 0 & 0 & 0 & 0 & 0 & 0 & 0 & 0 & 0 & 0 & 0 & & 0 & 0 \\
\hline N/A: Garden & & 0 & 0 & 0 & 0 & 0 & 0 & 0 & 0 & 0 & 0 & 0 & 0 & 0 & 0 & 0 & 0 & 0 & 0 & 0 & 0 & 0 & 0 & 0 & 0 & & 0 & 0 \\
\hline Assisted tathroom & & 0 & 5 & 10 & 6 & 0 & 0 & 8 & 13 & 16 & 0 & 11 & 1 & 7 & 0 & 2 & 1 & 1 & 5 & 0 & 0 & $\theta$ & 9 & 11 & 0 & & 5 & 0 \\
\hline N/A: WC & & 0 & 0 & 0 & 0 & 0 & 0 & 0 & 0 & 0 & 0 & 0 & 0 & 0 & 0 & 0 & & 0 & 0 & 0 & 0 & 0 & 0 & 0 & 0 & & 0 & 0 \\
\hline N/A: Clnico & & 0 & 0 & 0 & 0 & 0 & 0 & 0 & 0 & 0 & 0 & 0 & 0 & 0 & 0 & 0 & & 0 & 0 & 0 & 0 & 0 & 0 & 0 & 0 & & 0 & 0 \\
\hline N/A: Therapy room & & 0 & 0 & 0 & 0 & 0 & 0 & 0 & 0 & 0 & 0 & 0 & 0 & 0 & 0 & 0 & 0 & 0 & 0 & 0 & 0 & 0 & 0 & 0 & 0 & & 0 & 0 \\
\hline N/A: Gym & & 0 & 0 & 0 & 0 & 0 & 0 & 0 & 0 & 0 & 0 & 0 & 0 & 0 & 0 & 0 & 0 & 0 & 0 & 0 & 0 & 0 & 0 & 0 & 0 & & 0 & 0 \\
\hline NA: Hairchesser & & 0 & 0 & 0 & 0 & 0 & 0 & 0 & 0 & 0 & 0 & 0 & 0 & 0 & 0 & 0 & 0 & 0 & 0 & 0 & 0 & 0 & 0 & 0 & 0 & & 0 & 0 \\
\hline N/A: Shop & & 0 & 0 & 0 & 0 & 0 & 0 & 0 & 0 & 0 & 0 & 0 & 0 & 0 & 0 & 0 & 0 & 0 & 0 & 0 & 0 & 0 & 0 & 0 & 0 & & 0 & 0 \\
\hline N/A: Laundry & & 0 & 0 & 0 & 0 & 0 & 0 & 0 & 0 & 0 & 0 & 0 & 0 & 0 & 0 & 0 & 0 & 0 & 0 & 0 & 0 & 0 & 0 & 0 & 0 & & 0 & 0 \\
\hline N/A: Storege & & 0 & 0 & 0 & 0 & 0 & 0 & 0 & 0 & 0 & 0 & 0 & 0 & 0 & 0 & 0 & & 0 & 0 & 0 & 0 & 0 & 0 & 0 & 0 & & 0 & 0 \\
\hline NA: Refuse store & & 0 & 0 & 0 & 0 & 0 & 0 & 0 & 0 & 0 & 0 & 0 & 0 & 0 & 0 & 0 & 0 & 0 & 0 & 0 & 0 & 0 & 0 & 0 & 0 & & 0 & 0 \\
\hline
\end{tabular}




\begin{tabular}{|c|c|c|c|c|}
\hline Circulation: Generic & \multicolumn{4}{|c|}{ General Circulation * } \\
\hline Ha. ITEM & yes & no & $\begin{array}{l}\text { not in } \\
\text { use }\end{array}$ & n'a \\
\hline \multicolumn{5}{|l|}{ Building Elements } \\
\hline 1 Doors to rooms off the travel routes have a $m$ att finish & 0 & 0 & 0 & 0 \\
\hline 2 Doors to rooms off the travel routes are decorated in colours that contrast with the surrounding walls & 0 & 0 & 0 & 0 \\
\hline 3 All doors on travel routes have flush thre sholds & - & 0 & 0 & 0 \\
\hline \multicolumn{5}{|l|}{ Emironmental Design } \\
\hline 4 Handrails are provided along travel routes & 0 & 0 & 0 & 0 \\
\hline 5 Handrails do not have protruding ends that can catch on clothing or handbags & - & 0 & 0 & 0 \\
\hline 6 Handrails along travel rutes have circular or rounded edges & - & 0 & 0 & 0 \\
\hline 7 Handrails are smooth to touch & ○ & 0 & 0 & 0 \\
\hline 8 Handrails are in a contrasting colour to the walls & 0 & 0 & 0 & 0 \\
\hline \multicolumn{5}{|l|}{ Emvironmental Design } \\
\hline 9 Circulation spaces have radiators or underfloor heating & 0 & 0 & 0 & ○ \\
\hline 10 Radiators or underflo or heating have low surtace tem perature & 0 & 0 & 0 & 0 \\
\hline
\end{tabular}




\begin{tabular}{|c|c|c|c|c|}
\hline General circulation & \multicolumn{4}{|c|}{ Main Entrance * } \\
\hline Ha. ITEM & yes & no & $\begin{array}{l}\text { not in } \\
\text { use }\end{array}$ & n'a \\
\hline \multicolumn{5}{|l|}{ Layout } \\
\hline 1 It is possible to reach the refuse store from all living units without cossing lounges or dining areas & 0 & 0 & 0 & 0 \\
\hline 2 It is possible to reach the laundry from all living units without crossing lounges or dining areas & 0 & 0 & 0 & 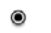 \\
\hline 3 The assisted bathroom is accessed via private rather than comm unal thoroughtares & 0 & 0 & 0 & 0 \\
\hline 4 No living units are accessed via double-banked corridors [Glossary 1.08] & ○ & 0 & 0 & o \\
\hline 5 There is a securty barier between the public area and the lifts & 0 & o & 0 & 0 \\
\hline 6 There is a securtty barrier between the public area and the living units & 0 & 0 & 0 & 0 \\
\hline 7 Different colour schemes are used to distinguish separate zones & 0 & ○ & 0 & o \\
\hline 8 Different $m$ aterials or textures are used to distinguish separate zones & - & o & 0 & 0 \\
\hline 9 There is dear delineation of public, comm unity and private space within the scheme & 0 & 0 & 0 & - \\
\hline $10 \mathrm{Public}$ areas are more brightly lit with natural light than private areas [Glossary 1.09 ] & $\mathrm{O}$ & $\mathrm{O}$ & 0 & ○ \\
\hline 11 Public areas are indicated by their larger scale and higher ceilings [Glossary 1.10$]$ & 0 & 0 & 0 & - \\
\hline \multicolumn{5}{|l|}{ Services and Systems } \\
\hline 12 Audible alarms are supplem ented with flashing beacons & 0 & 0 & 0 & - \\
\hline
\end{tabular}




\begin{tabular}{|c|c|c|c|c|}
\hline \multirow{2}{*}{$\begin{array}{l}\text { Internal } \\
\text { Ho. ITEM }\end{array}$} & \multicolumn{4}{|c|}{ External Covered: } \\
\hline & \multirow[t]{2}{*}{ yes } & \multirow[t]{2}{*}{ no } & \multicolumn{2}{|c|}{$\begin{array}{l}\text { not in nia } \\
\text { use }\end{array}$} \\
\hline \multicolumn{3}{|l|}{ Layout } & & \\
\hline 1 The corridors are wide enough to accomm odate two wheelchairs side by side (more than $1800 \mathrm{~mm}$ ) & 0 & 0 & 0 & 0 \\
\hline 2 Splayed or radius corners are provided at corridor junctions [Glossary 1.13] & 0 & 0 & 0 & ○ \\
\hline 3 Doors that open onto corridors are recessed & 0 & 0 & 0 & () \\
\hline 4 There are resting areas at less than $30 \mathrm{~m}$ intervals along the travel routes & (- & 0 & 0 & 0 \\
\hline $\begin{array}{l}\text { Electric scooter parks are available adjacent to individual living units (bay length m ore than } 2400 \mathrm{~m} m \text {, bay } \\
\text { width more than } 1200 \mathrm{~m} \mathrm{~m} \text { ) }\end{array}$ & 0 & O & 0 & 0 \\
\hline 6 A corridor width $m$ ore than $1800 \mathrm{~mm}$ is $\mathrm{m}$ aintained adjacent to the electric scooter parks & 0 & 0 & 0 & 0 \\
\hline 7 The travel route from the com munal facilities to the living units is level [Glossary 1.14] & ○ & O & $\mathrm{O}$ & O \\
\hline \multicolumn{5}{|l|}{ Building Elements } \\
\hline 8 Doors to rooms off the travel routes have a matt finish & ○ & 0 & 0 & 0 \\
\hline 9 Doors to rooms off the travel routes are decorated in colours that contrast with the surrounding walls & ○ & 0 & 0 & $\mathrm{O}$ \\
\hline 10 All doors on travel routes have flush thresholds & - & 0 & 0 & 0 \\
\hline 11 Fire doors along travel routes have autom atic hold open dosers or have power-assisted opening & - & 0 & 0 & 0 \\
\hline 12 All fire exits on the ground floor have level access & ○ & $\mathrm{O}$ & 0 & O \\
\hline 13 Fire extinguishers, radiators etc. are recessed and do not protrude into corridors & - & 0 & 0 & 0 \\
\hline \multicolumn{5}{|l|}{ Fittings - Handrails } \\
\hline 14 Handrails are provided along travel routes & 0 & 0 & 0 & 0 \\
\hline 15 Handrails do not have protruding ends that can catch clothing or handbags & - & 0 & 0 & 0 \\
\hline 16 Handrails along travel routes have circular or rounded edges & ○ & 0 & 0 & 0 \\
\hline 17 Handrails along travel routes are sm ooth to touch & 0 & 0 & 0 & 0 \\
\hline 18 Handrails are in a contrasting colour to the walls & ○ & 0 & 0 & 0 \\
\hline \multicolumn{5}{|l|}{ Fittings - General } \\
\hline 19 There are distinctive internal landm arks at less than $30 \mathrm{~m}$ along the travel routes [Glossary 3.03] & - & 0 & 0 & 0 \\
\hline 20 Significart points along the travel route(s) are highlighted [Glossary 3.04 ] & - & 0 & 0 & 0 \\
\hline \multicolumn{5}{|l|}{ Environmental Design } \\
\hline 21 Corridors are illuminated with natural light & 0 & - & 0 & 0 \\
\hline 22 S, E,W facing windows are free from obstruction to direct sunilight & 0 & 0 & 0 & 0 \\
\hline 23 There are external reference views visible from the circulation space [Glossary 4.20$]$ & 0 & 0 & 0 & 0 \\
\hline
\end{tabular}




\begin{tabular}{|c|c|c|c|c|}
\hline 24 The travel routes have vie ws of outside or internal countyand(s) & 0 & 0 & 0 & 0 \\
\hline 25 The travel routes windows provide a view of the open sty & 0 & 0 & 0 & o \\
\hline 26 The travel route windows overtook outdoor spaces where there is human activity & 0 & 0 & 0 & 0 \\
\hline 27 The vew from the travel route windons consists of near and distant fe atures of interest & 0 & 0 & 0 & ० \\
\hline 28 The wew from the travel route windows consists of natural features $(\mathrm{e} g \mathrm{~g} . \mathrm{trees}$, whter) & 0 & 0 & 0 & o \\
\hline 29 The view from the travel route windows is tree from obstructions, eg. a blank wall & 0 & 0 & 0 & o \\
\hline 30 Elinds are fitted on windo ws at the end of conridors & O & 0 & 0 & 0 \\
\hline 31 The artificial light in the travel routes is well distributed with no areas of deep shado ws & ○ & 0 & 0 & 0 \\
\hline 32 The electric light illuminance is more than $200 \mathrm{lux}$ & ○ & ० & 0 & ○ \\
\hline $\begin{array}{l}\text { The illuminance for dayighting measured at floor level in the darkest part of the droulation space is more } \\
\text { than } 10 \% \text { of the electrical light illuminance }\end{array}$ & ○ & 0 & 0 & ○ \\
\hline 34 Internal circulation spaces have radiators or underfloor heating & 0 & 0 & 0 & ○ \\
\hline 35 Radilitors or undertloor heating have low surface temperature & 0 & 0 & 0 & 0 \\
\hline 36 The internal circulation space background temperature is $21 \mathrm{deg} C$ & 0 & 0 & 0 & ○ \\
\hline \multicolumn{5}{|l|}{ Environmental Design - Seating Areas } \\
\hline 37 There are communal seating areas in circulation spaces [Glossary 3.05 ] & 0 & 0 & 0 & ○ \\
\hline 38 Seating area 1 has window(s) with a view of the open sky & 0 & 0 & 0 & ○ \\
\hline 39 Seating area 1 has window(s) that overlook outdoor spaces where there is hum an activity & 0 & 0 & 0 & ○ \\
\hline 40 Seating area 1 has window(s) with a view of near and distant features of interest & 0 & 0 & 0 & - \\
\hline 41 Seating area 1 has window(s) with a vew of natural features & 0 & 0 & 0 & ○ \\
\hline 42 Seating area 1 has a daylight factor $m$ ore than 2 & 0 & 0 & 0 & ○ \\
\hline 43 Seating area 2 has window(s) with a view of the open sky & 0 & 0 & 0 & ○ \\
\hline 44 Seating area 2 has window(s) that overlook outdoor spaces where there is hum an activity & 0 & 0 & 0 & ( ) \\
\hline 45 Seating area 2 has window(s) with a view of near and distant features of interest & 0 & 0 & 0 & - \\
\hline 46 Seating area 2 has window(s) with a view of natural features & 0 & $\mathrm{O}$ & 0 & - \\
\hline 47 Seating area 2 has a daylight factor more than 2 & 0 & 0 & 0 & ○ \\
\hline 48 Seating area 3 has window(s) with a view of the open sky & 0 & 0 & 0 & ○ \\
\hline 49 Seating area 3 has window(s) that overlook outdoor spaces where there is hum an activity & 0 & 0 & 0 & ○ \\
\hline 50 Seating area 3 has window(s) with a view of near and distant features of interest & 0 & 0 & 0 & ○ \\
\hline 51 Seating area 3 has window(s) with a view of natural features & o & 0 & 0 & - \\
\hline 52 Seating area 3 has a daylight factor more than 2 & O & 0 & 0 & ○ \\
\hline 53 Seating area 4 has window(s) with a view of the open sky & o & 0 & 0 & - \\
\hline 54 Seating area 4 has window(s) that overlook outdoor spaces where there is hum an activity & 0 & 0 & 0 & 0 \\
\hline
\end{tabular}




\begin{tabular}{l|llll}
\hline 55 Seating area 4 has window(s) with a view of near and distart features of interest & 0 & 0 & 0 \\
\hline 56 Seating area 4 has window(s) with a view of natural features & 0 & 0 & 0 \\
\hline 57 Seating area 4 has a daylight factor more than 2 & 0 & 0 & 0 \\
\hline Finishes & & & \\
\hline 58 Shiny floor finishes are avoided along travel routes & 0 & 0 & 0 \\
\hline 59 Deep pile carpets are avoided on circulation routes & 0 & 0 & 0 & 0 \\
\hline
\end{tabular}




\section{evolve}

Circulation: Results for individual spaces

Results for unit »

The Village of Humber Heights

Display chart for General circulation

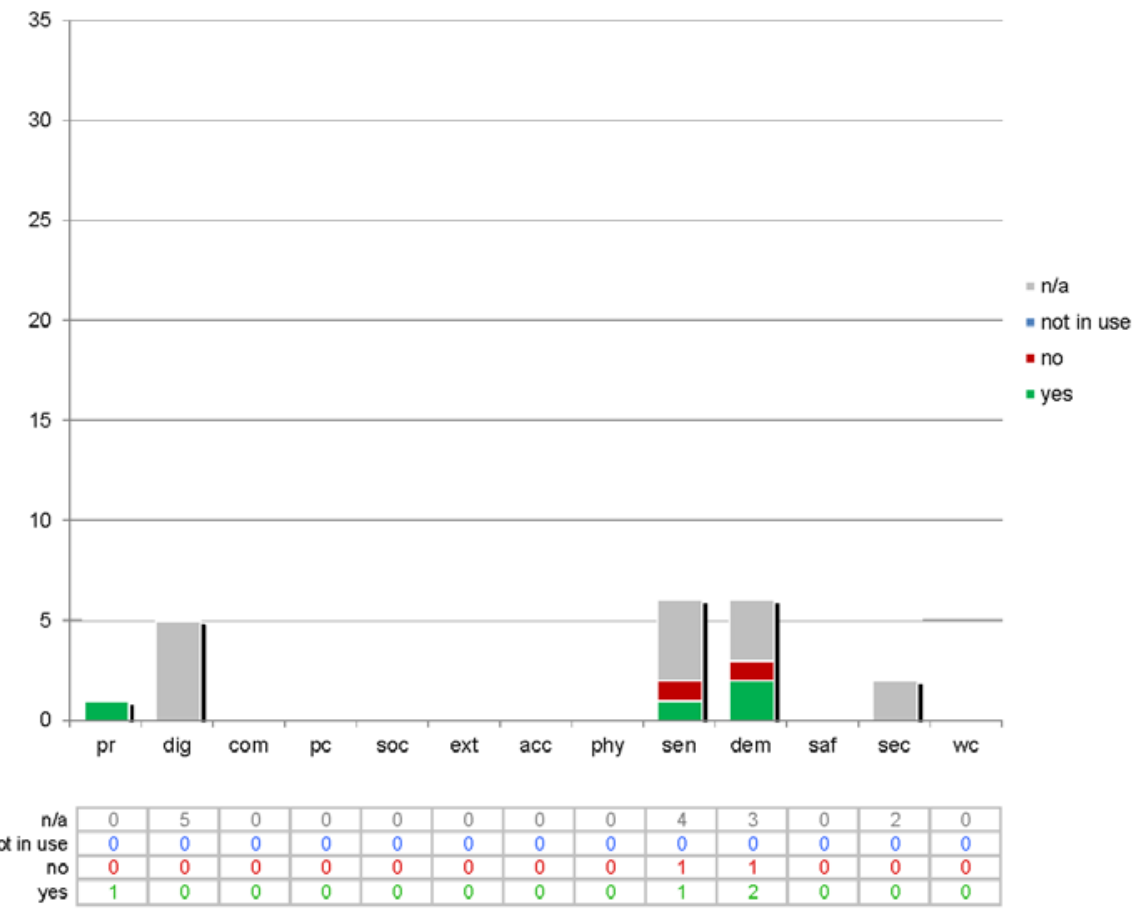




\section{evolve}

Circulation: Results for individual spaces

Results for unit »

The Village of Humber Heights

Display chart for Internal

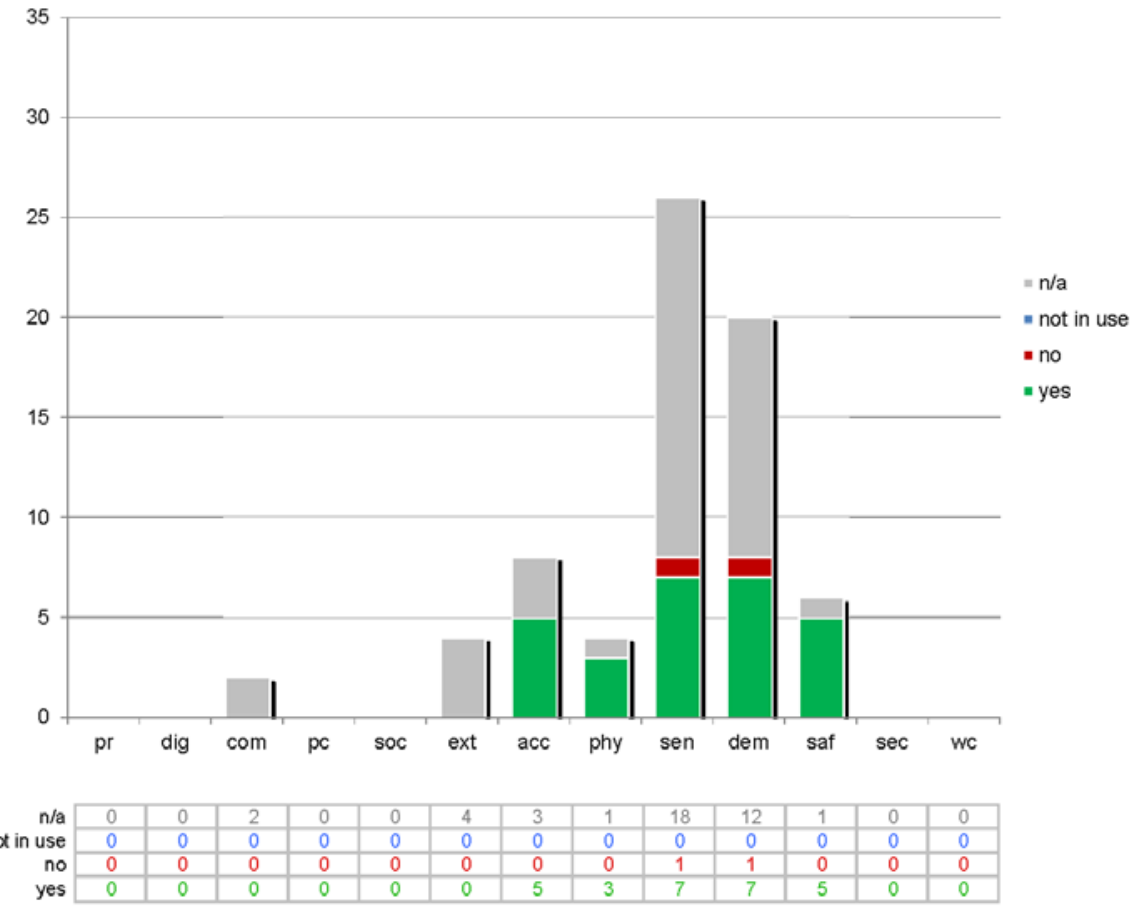




\section{evolve \\ Circulation: Results for unit}

The Village of Humber Heights

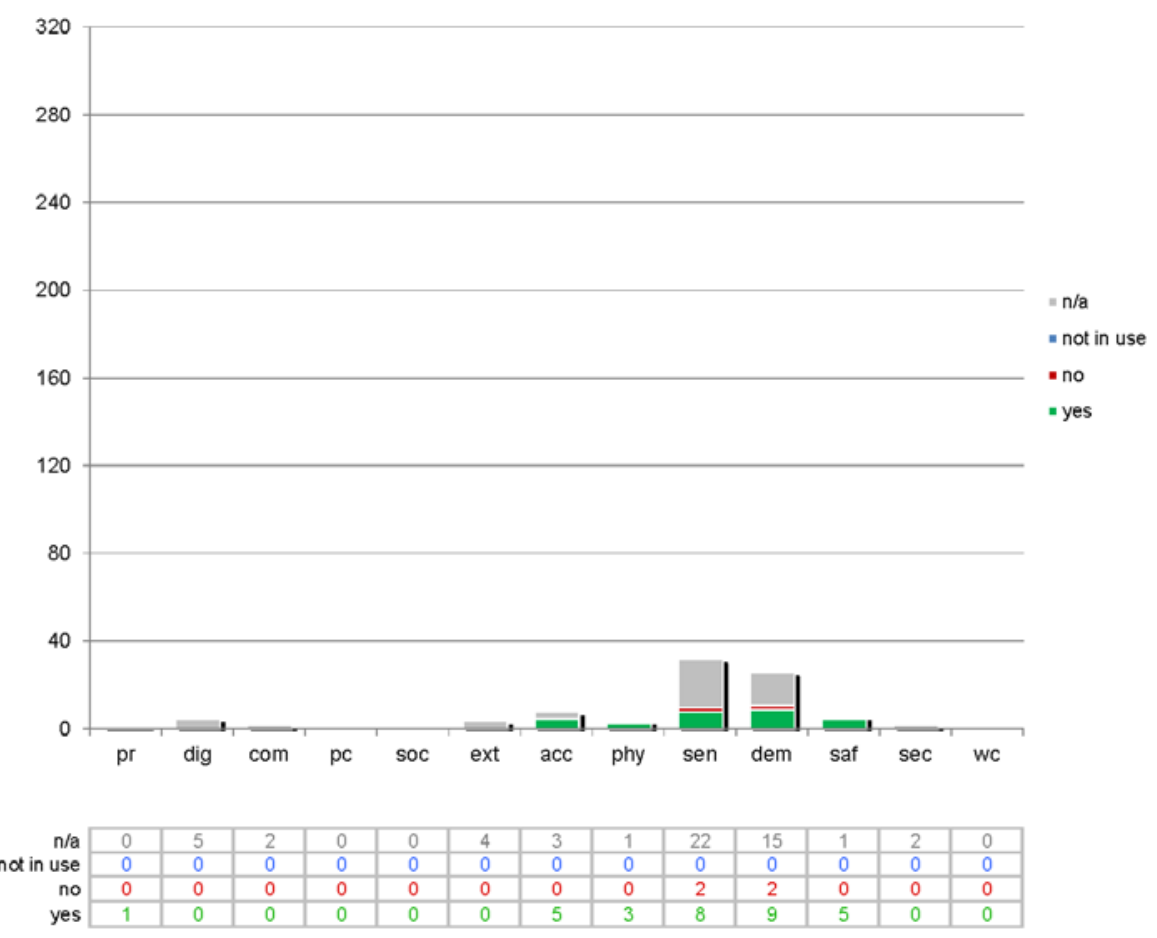




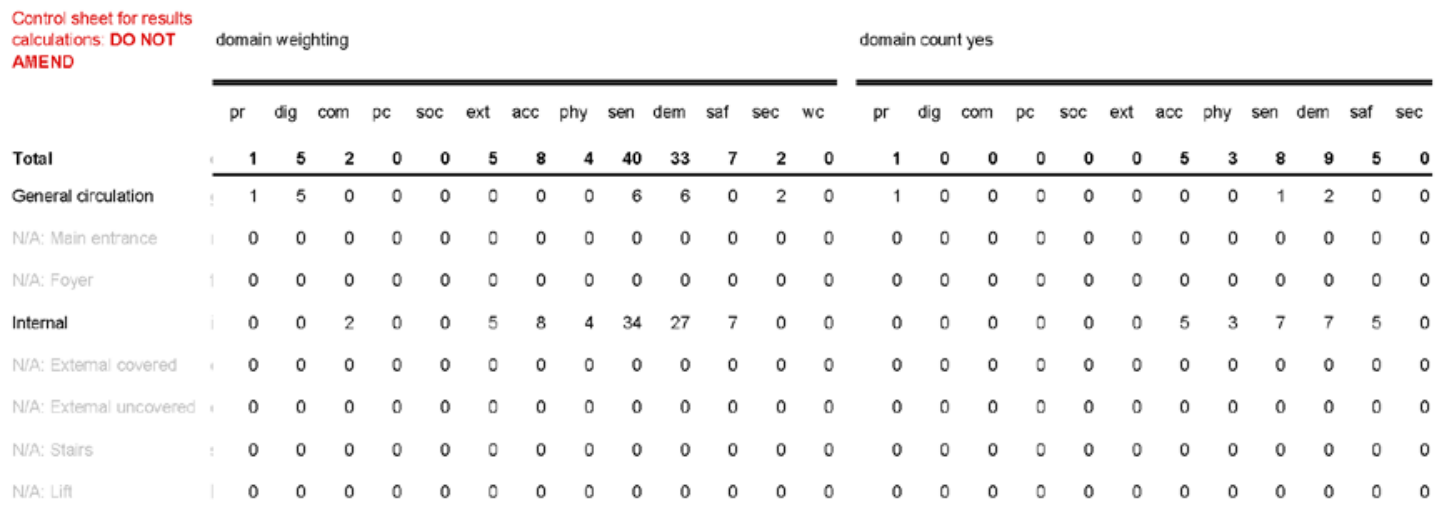




\begin{tabular}{|c|c|c|c|c|c|c|c|c|c|c|c|c|c|c|c|c|c|c|c|c|c|c|c|c|c|c|c|c|c|}
\hline & \multicolumn{13}{|c|}{ domain count no } & \multicolumn{13}{|c|}{ domain count not in use } & \multicolumn{3}{|c|}{ domain coun } \\
\hline$w C$ & $\mathrm{pr}$ & $\mathrm{dig}$ & com & $\mathrm{pc}$ & soc & ext & acc & phy & sen & dem & saf & $\mathrm{sec}$ & wc & pr & dig & com & $\mathrm{pc}$ & soc & ext & acc & phy & $\operatorname{sen}$ & dem & saf & $\sec$ & wc & & $\mathrm{pr}$ & dig \\
\hline 0 & 0 & 0 & 0 & 0 & 0 & 0 & 0 & 0 & 1 & 1 & 0 & 0 & 0 & 0 & 0 & 0 & 0 & 0 & 0 & 0 & 0 & 0 & 0 & 0 & 0 & & 0 & 0 & 5 \\
\hline 0 & 0 & 0 & 0 & 0 & 0 & 0 & 0 & 0 & 0 & 0 & 0 & 0 & 0 & 0 & 0 & 0 & 0 & 0 & 0 & 0 & 0 & 0 & 0 & 0 & 0 & & 0 & 0 & 0 \\
\hline 0 & 0 & 0 & 0 & 0 & 0 & 0 & 0 & 0 & 1 & 1 & 0 & 0 & 0 & 0 & 0 & 0 & 0 & 0 & 0 & 0 & 0 & 0 & 0 & 0 & 0 & & 0 & 0 & 0 \\
\hline 0 & 0 & 0 & 0 & 0 & 0 & 0 & 0 & 0 & 0 & 0 & 0 & 0 & 0 & 0 & 0 & 0 & 0 & 0 & 0 & 0 & 0 & 0 & 0 & 0 & 0 & & 0 & 0 & 0 \\
\hline 0 & 0 & 0 & 0 & 0 & 0 & 0 & 0 & 0 & 0 & 0 & 0 & 0 & 0 & 0 & 0 & 0 & 0 & 0 & 0 & 0 & 0 & 0 & 0 & 0 & 0 & & 0 & 0 & 0 \\
\hline 0 & 0 & 0 & 0 & 0 & 0 & 0 & 0 & 0 & 0 & 0 & 0 & 0 & 0 & 0 & 0 & 0 & 0 & 0 & 0 & 0 & 0 & 0 & 0 & 0 & 0 & & 0 & 0 & 0 \\
\hline 0 & 0 & 0 & 0 & 0 & 0 & 0 & 0 & 0 & 0 & 0 & 0 & 0 & 0 & 0 & 0 & 0 & 0 & 0 & 0 & 0 & 0 & 0 & 0 & 0 & 0 & & 0 & 0 & 0 \\
\hline
\end{tabular}


com pc soc ext acc phy sen dem saf sec wC \begin{tabular}{rrrrrrrrrrr}
2 & 0 & 0 & 4 & 3 & $\mathbf{1}$ & $\mathbf{2 2}$ & $\mathbf{1 5}$ & $\mathbf{1}$ & $\mathbf{2}$ & $\mathbf{0}$ \\
\hline 0 & 0 & 0 & 0 & 0 & 0 & 4 & 3 & 0 & 2 & 0
\end{tabular}

$\begin{array}{lllllllllll}0 & 0 & 0 & 0 & 0 & 0 & 0 & 0 & 0 & 0 & 0\end{array}$

$\begin{array}{lllllllllll}0 & 0 & 0 & 0 & 0 & 0 & 0 & 0 & 0 & 0 & 0\end{array}$

$\begin{array}{lllllllllll}2 & 0 & 0 & 4 & 3 & 1 & 18 & 12 & 1 & 0 & 0\end{array}$

$\begin{array}{lllllllllll}0 & 0 & 0 & 0 & 0 & 0 & 0 & 0 & 0 & 0 & 0\end{array}$

$\begin{array}{lllllllllll}0 & 0 & 0 & 0 & 0 & 0 & 0 & 0 & 0 & 0 & 0\end{array}$

$\begin{array}{lllllllllll}0 & 0 & 0 & 0 & 0 & 0 & 0 & 0 & 0 & 0 & 0\end{array}$

$\begin{array}{lllllllllll}0 & 0 & 0 & 0 & 0 & 0 & 0 & 0 & 0 & 0 & 0\end{array}$ 